Prepared in cooperation with the Pajaro Valley Water Management Agency

\title{
Integrated Hydrologic Model of Pajaro Valley, Santa Cruz and Monterey Counties, California
}

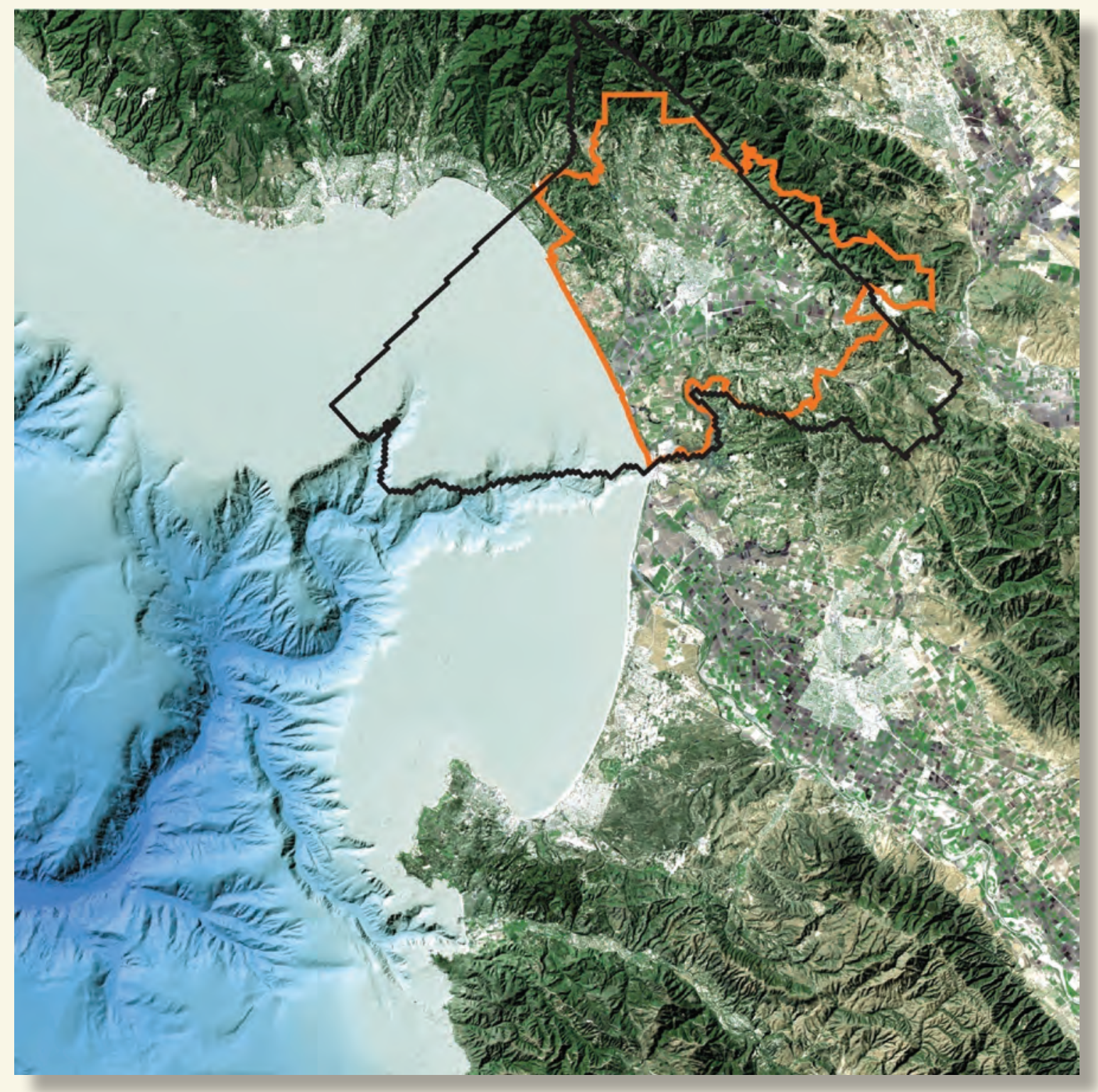

Scientific Investigations Report 2014-5111 
Cover. Base image for cover illustration provided courtesy of the Monterey Bay Aquarium Research Institute. The black line is the extent of the model grid described in this report. The orange line is the boundary of the Pajaro Valley Municipal Water Agency. 


\section{Integrated Hydrologic Model of Pajaro Valley, Santa Cruz and Monterey Counties, California}

By R.T. Hanson', Wolfgang Schmid ${ }^{2}$, Claudia C. Faunt' ${ }^{1}$, Jonathan Lear ${ }^{3}$, and Brian Lockwood ${ }^{4}$

${ }^{4}$ Pajaro Valley Water Management Agency

Prepared in cooperation with Pajaro Valley Water Management Agency

Scientific Investigations Report 2014-5111 


\title{
U.S. Department of the Interior SALLY JEWELL, Secretary
}

\section{U.S. Geological Survey \\ Suzette M. Kimball, Acting Director}

\author{
U.S. Geological Survey, Reston, Virginia: 2014
}

For more information on the USGS - the Federal source for science about the Earth, its natural and living resources, natural hazards, and the environment, visit http://www.usgs.gov or call 1-888-ASK-USGS.

For an overview of USGS information products, including maps, imagery, and publications, visit http://www.usgs.gov/pubprod

To order this and other USGS information products, visit http://store.usgs.gov

Any use of trade, firm, or product names is for descriptive purposes only and does not imply endorsement by the U.S. Government.

Although this information product, for the most part, is in the public domain, it also may contain copyrighted materials as noted in the text. Permission to reproduce copyrighted items must be secured from the copyright owner.

Suggested citation:

Hanson, R.T., Schmid, Wolfgang, Faunt, C.C., Lear, Jonathan, and Lockwood, Brian, 2014, Integrated hydrologic model of Pajaro Valley, Santa Cruz and Monterey Counties, California: U.S. Geological Survey Scientific Investigations Report 2014-5111, 166 p., http://dx.doi.org/10.3133/sir20145111.

ISBN 978-1-4113-3912-5

ISSN 2328-031X (print)

ISSN 2328-0328 (online) 


\section{Contents}

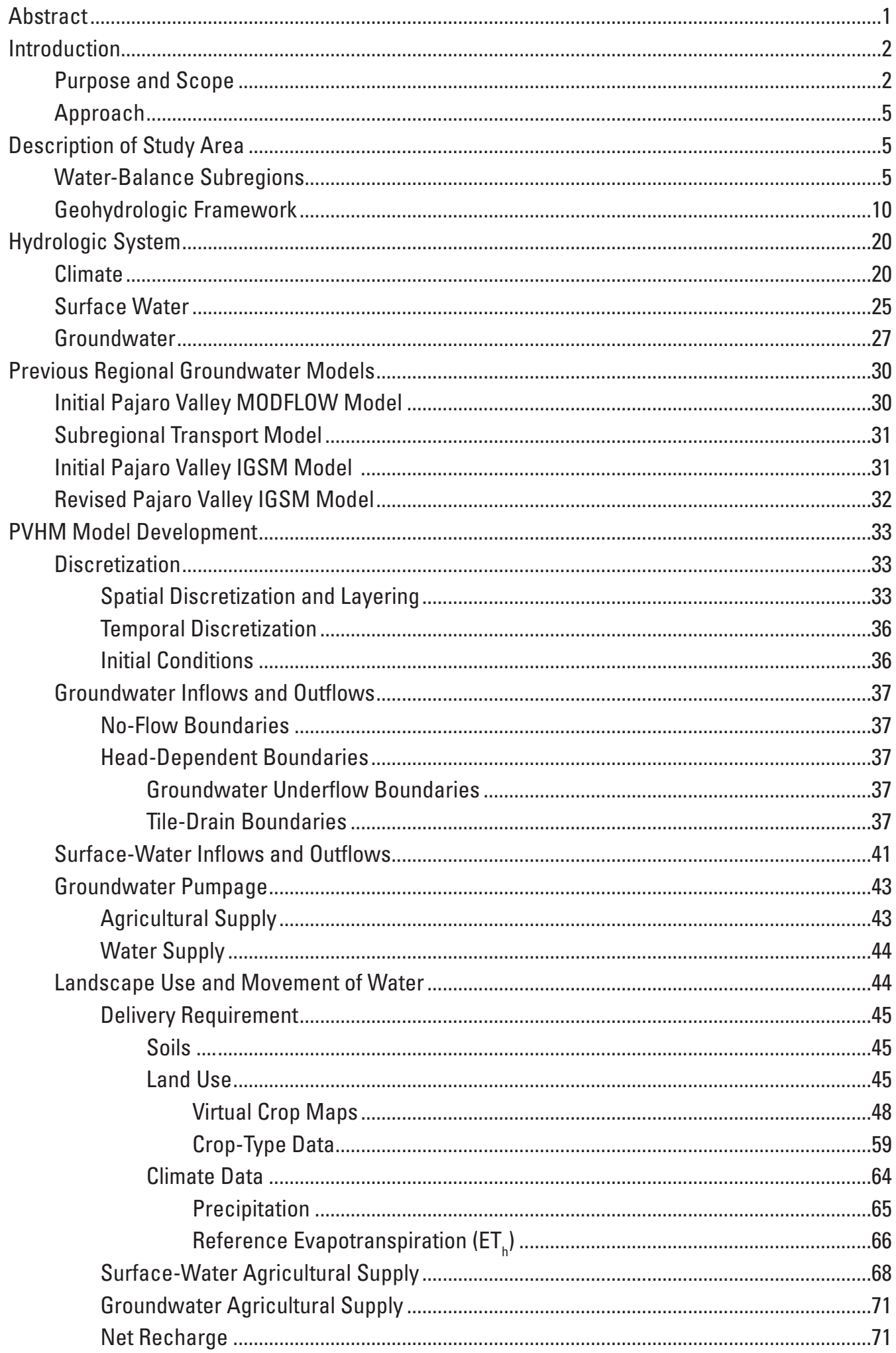




\section{Contents-Continued}

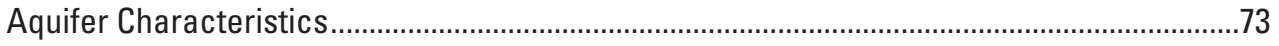

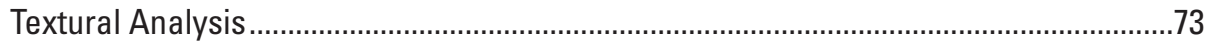

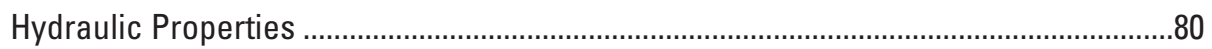

Hydraulic Conductivity of Lithologic End Members................................................82

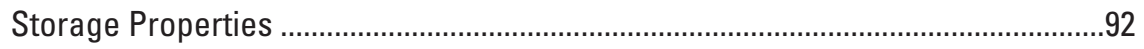

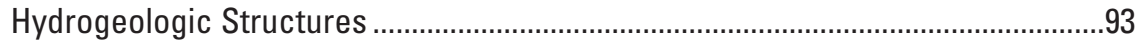

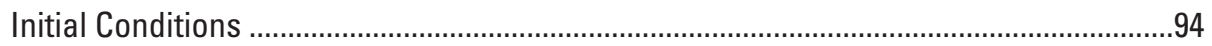

Model Calibration and Sensitivity ....................................................................................................94

Measurements and Observations Used in Model Calibration ...................................................95

Groundwater Observations ..............................................................................................95

Groundwater-Level Maps....................................................................................121

Inland Pajaro Valley......................................................................................... 121

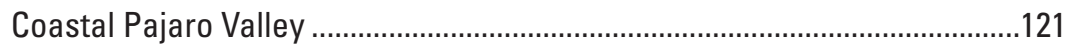

Streamflow Observations ............................................................................................. 126

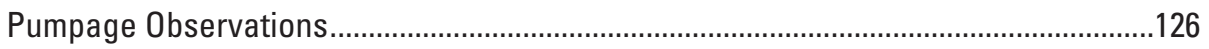

Water-Delivery Observations....................................................................................... 134

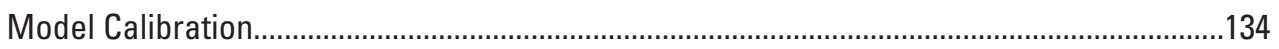

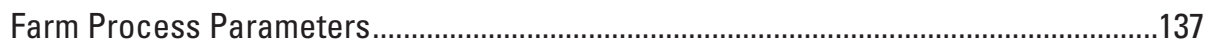

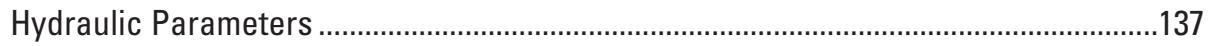

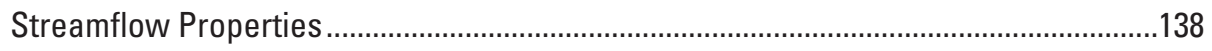

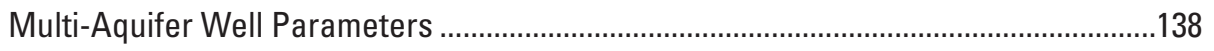

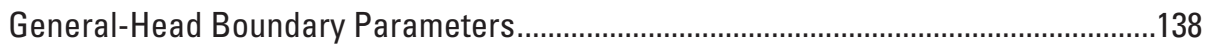

Horizontal Flow Barrier Parameters .................................................................................138

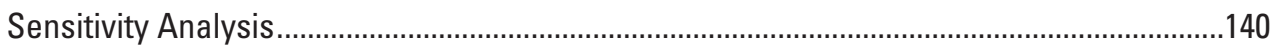

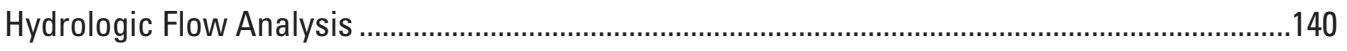

Model Uncertainty, Limitations, and Potential Improvements ....................................................155

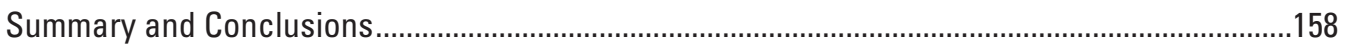

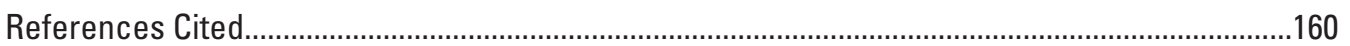

\section{Figures}

1. Maps showing $A$, generalized location with place names, watersheds, rivers, water agency boundaries, extent of active model grid, and offshore bathymetry; and $B$, detailed location map with model grid, Pajaro Valley, California...

2. Maps showing $A$, Oblique, quasi-three-dimensional diagram showing conceptual model for the hydrologic cycle; $B$, the Pajaro Valley Hydrologic Model model region, water-balance subregions and water districts, and area of seawater intrusion; $C$, regional groups of water-balance subregions in Pajaro Valley, California.

3. Map showing generalized $A$, outcrops of geologic units and major faults within model grid; $B$, estimated thickness of each of the hydrogeologic model layers; and $C$, hydrogeologic sections $\left(A-A^{\prime}\right.$ and $\left.B-B^{\prime}\right)$ of hydrogeologic units used as model layers inthe Pajaro Valley, California 


\section{Figures-Continued}

4. Graph showing $A$, wet-dry periods, land-use map periods, periods of application for land-use maps, and precipitation cumulative departure; map showing

$B$, average annual precipitation; graph showing $C$, average annual precipitation for the simulation period; and map showing $D$, average annual reference evapotranspiration for the simulation period, Pajaro Valley, California...

5. Map showing the stream network with streamflow routing cells and segments, streamgaging stations and other measurement sites, and location of inflows and diversions, Pajaro Valley, California

6. Maps showing $A$, distribution of agricultural, urban-supply, and domestic wells (indicate single and multi-aquifer wells); and $B$, modeled tile drain areas,

Pajaro Valley, California

7. Graph showing estimated groundwater pumpage from municipal and domestic wells, Pajaro Valley, California.

8. Diagram showing the flow interdependencies within MODFLOW-FMP2 between the landscape, streamflow, and groundwater flow components required to simulate a coupled hydrologic flow system.

9. Map showing $A$, distribution of general-head boundaries for aquifer layers;

$B$, hydrographs of general head boundaries and sea level; and $C$, distribution of tile-drain agricultural land, Pajaro Valley, California.

10. Map showing distribution of model cells used for streams, colored by conductance values of model cells estimated during calibration.

11. Map showing agricultural soil types for the Pajaro Valley, simplified from Soil Survey Geographic Database

12. Map showing land-use (virtual crop) groups discretized to model grid for 1970 (modified with 2000 data) and pie chart of percentages of total land use over model area, Pajaro Valley, California ...

13. Map showing land-use (virtual crop) for $\mathbf{1 9 8 9}$ and pie chart of percentages of total land use over entire model area, Pajaro Valley, California

14. Map showing land-use (virtual crop) groups discretized to model grid for 1991, and pie chart of percentage of total land use over entire model area, Pajaro Valley, California

15. Map showing land-use (virtual crop) groups discretized to model grid for 1993, and pie chart of percentage of total land use over entire model area, Pajaro Valley, California

16. Map showing land-use (virtual crop) groups discretized to model grid for 1997, and pie chart of percentage of total land use over entire model area, Pajaro Valley, California.

17. Map showing land-use (virtual crop) groups discretized to model grid for 2000, and pie chart of percentage of total land use over entire model area, Pajaro Valley, California

18. Map showing $A$, actual major categories of land-use for 2006; $B, 2006$ model equivalent land-use (virtual crop) groups discretized to model grid, and pie chart of percentage of total land use over entire model area; $C, 2009$ model equivalent land-use (virtual crop) groups discretized to model grid, and pie chart of percentage of total land use over entire model area; and $D$, changes in percentages of selected land use through time (2000-09), Pajaro Valley, California 


\section{Figures-Continued}

19. Graph showing monthly crop coefficients for $A$, fruits and vegetables; $B$, grains and turf, $C$, native and pasture; and $D$, crops with modified growth or double crops in the Pajaro Valley, California

20. Graph showing monthly California Irrigation Management Information System $\mathrm{ET}_{\mathrm{h}}$ and Hargrave-Semani $\mathrm{ET}_{\mathrm{h}}$ values through time for selected stations in Pajaro Valley, California

21. Diagrams showing the $A$, structure of local water deliveries, and $B$, hierarchy of simulated operation of the aquifer-storage-and-recovery system and Coastal Distribution System (CDS) water deliveries to the regions serviced by the CDS, Pajaro Valley, California

22. Map showing Coastal Distribution System (CDS) portion of the PVHM, selected water-balance subregions, selected wells, Aquifer-Storage-and-Recovery System, and CDS, Pajaro Valley, California.

23. Graphs showing $A$, simulated and reported deliveries to the aquifer-storage-and-recovery system; $B$, simulated and reported deliveries from the Coastal Delivery System (CDS); and $C$, simulated and reported total deliveries from the CDS, and by water budget subarea, Pajaro Valley, California

24. Maps showing distribution of coarse-grained deposits for $A$, layer $1 ; B$, layer $3 ; C$, layer 5 ; and $D$, layer 6 of the hydrologic model, Pajaro Valley, California.

25. Maps showing distribution of fine-grained deposits for $A$, the alluvial confining unit (model layer 2) and $B$, the upper Aromas confining unit (model layer 4) Pajaro Valley, California

26. Graph showing relation of hydraulic conductivity and percentage coarse-grained deposits based on hydraulic conductivity end members and exponent of the power mean, with selected values from aquifer tests or specific capacity tests in Pajaro Valley, California .....

27. Maps showing distribution of subareas, or zones, for hydraulic properties for model layers $A, 1 ; B, 2 ; C, 3 ; D, 4 ; E, 5$; and $F, 6$ in the Pajaro Valley, California.

28. Map showing calibration data sites, including wells for groundwater levels and water-level differences, streamflow gages, streamflow leakage reaches, and streamflow diversions for the Pajaro Valley Hydrologic Model, Pajaro Valley, California

29. Graph showing $A$, histogram of distribution of water-level residuals (observed minus simulated) for the Pajaro Valley hydrologic model and the Pajaro Valley integrated groundwater-surface water models; and $B$, correlation graphs of measured versus simulated water levels, by subregions, Pajaro Valley, California.

30. Hydrographs showing simulated and measured hydrographs for selected wells in $A$, Santa Cruz County Inland; $B$, Monterey County Inland; $C$, Santa Cruz County Coastal (Non-CDS); $D$, Santa Cruz County Coastal (CDS); $E$, Monterey County Coastal (Non-CDS); F, Monterey County Coastal (CDS); and G, Santa Cruz County Monitoring Wells, Pajaro Valley, California

31. Graphs of simulated and measured hydrographs of vertical water-level differences for selected monitoring wells in Pajaro Valley, California...

32. Map showing average residual at observation wells for the calibrated transient groundwater flow model throughout the Pajaro Valley

33. Maps comparing the contoured measured with simulated water levels $A$, in 1987; $B$, in 1992; $C$, in 1998; and $D$, in September 2006 for the calibrated hydrologic flow model, Pajaro Valley, California 


\section{Figures-Continued}

34. Graph showing reported and simulated $A$, selected downstream streamflows;

$B$, City of Watsonville upstream diversions; and $C$, selected streamflow gains and losses, Pajaro Valley, California.

35. Map showing distribution of median streamflow loss by stream segments for the

Pajaro Valley, California

36. Graphs showing $A$, total reported and simulated pumpage for each water-balance subregion for the period 2006-09; $B$, percentages of measured and simulated agricultural pumpage for 2006-09; and $C$, total annual and total annual agricultural reported and simulated pumpage from 2002-09, Pajaro Valley,California

37. Graphs showing the temporal distribution of reported and simulated pumpage for the three water-balance subregions that receive water during some part of the last five years (2006-09), Pajaro Valley, California.

38. Relative composite sensitivity of computed heads, flows, and pumpage information at calibration points to changes in parameters

39. Flow chart showing the simulated average flow of groundwater through the hydrologic cycle, Pajaro Valley, California

40. Stacked bar chart showing the temporal distribution of $A$, total inflows and outflows; and $B$, total net inflows and outflows to the simulated groundwater flow system within the Pajaro Valley hydrologic model, Pajaro Valley, California.

41. Stacked bar chart showing simulated groundwater pumpage for the water years 1964-2006, for $A$, total for all model layers; and $B$, net for aquifer layers, Pajaro Valley, California

42. A, Stacked bar chart showing temporal distribution of total inflows and outflows; and $B$, Pie chart showing average annual components of farm budget of the simulated landscape flow system within the PVHM hydrologic model, Pajaro Valley, California

43. Stacked bar charts showing $A$, Total recharge by aquifer model layers, and $B$, net downward flow between upper aquifer model layers; and $C$, map showing distribution of median farm net recharge, Pajaro Valley, California

44. Stacked bar chart showing temporal distribution of $A$, net changes in storage; and $B$, net coastal flows by major subregions as surrogate for seawater intrusion, Pajaro Valley, California

\section{Tables}

1. Summary of water-balance subregions and grouped water balance regions for the Pajaro Valley Hydrologic Model, Pajaro Valley, California.

2. Summary of climate periods, related model simulation, and related land-use periods for the Pajaro Valley

3. Summary of MODFLOW-2005 with Farm Process packages and processes used with the hydrologic flow model of Pajaro Valley, California

4. Coordinates of the hydrologic flow model of Pajaro Valley, California .36

5. Wells from which water levels were used for time-varying Boundary Heads of General-Head Boundaries

6. Land use periods with acreage in square miles and percentage of different virtual crop categories, Pajaro Valley, California.

7. Summary of Pajaro Valley virtual crop categories and properties, the Pajaro Valley hydrologic model, Pajaro Valley, California . 


\section{Tables-Continued}

8. Summary of fractions of transpiration and evaporation by month for Pajaro Valley crop categories (virtual crops)

9. Range of irrigation efficiencies for each crop for all water-balance subregions within Pajaro Valley hydrologic model, Pajaro Valley, California.

10. Summary of variogram model properties for the Pajaro Valley hydrogeologic units ............73

11. Summary of hydraulic properties estimated from the Pajaro Valley Hydrologic Model calibration and previous groundwater models with grain-size adjusted values from selected aquifer tests.

12. Summary of parameter zones and related property parameter names used to calibrate horizontal hydraulic conductivity, vertical hydraulic conductivity, and specific storage and specific yield in the Pajaro Valley hydrologic model, Pajaro Valley, California

13. Summary of parameter values and sentivities estimated for the Pajaro Valley hydrologic model, Pajaro Valley, California

14. Summary of streambed vertical hydraulic conductivity parameters and calibrated values, Pajaro Valley, California.

\section{Conversion Factors}

Inch/Pound to SI

\begin{tabular}{|c|c|c|}
\hline Multiply & By & To obtain \\
\hline \multicolumn{3}{|c|}{ Length } \\
\hline inch (in.) & 2.54 & centimeter $(\mathrm{cm})$ \\
\hline inch (in.) & 25.4 & millimeter $(\mathrm{mm})$ \\
\hline foot (ft) & 0.3048 & meter $(\mathrm{m})$ \\
\hline mile (mi) & 1.609 & kilometer (km) \\
\hline \multicolumn{3}{|c|}{ Area } \\
\hline acre & 4,047 & square meter $\left(\mathrm{m}^{2}\right)$ \\
\hline acre & 0.4047 & hectare (ha) \\
\hline acre & 0.4047 & square hectometer $\left(\mathrm{hm}^{2}\right)$ \\
\hline acre & 0.004047 & square kilometer $\left(\mathrm{km}^{2}\right)$ \\
\hline square foot $\left(\mathrm{ft}^{2}\right)$ & 929.0 & square centimeter $\left(\mathrm{cm}^{2}\right)$ \\
\hline square foot $\left(\mathrm{ft}^{2}\right)$ & 0.09290 & square meter $\left(\mathrm{m}^{2}\right)$ \\
\hline square mile $\left(\mathrm{mi}^{2}\right)$ & 259.0 & hectare (ha) \\
\hline square mile $\left(\mathrm{mi}^{2}\right)$ & 2.590 & square kilometer $\left(\mathrm{km}^{2}\right)$ \\
\hline \multicolumn{3}{|c|}{ Volume } \\
\hline acre-foot (acre-ft) & 1,233 & cubic meter $\left(\mathrm{m}^{3}\right)$ \\
\hline acre-foot (acre-ft) & 0.001233 & cubic hectometer $\left(\mathrm{hm}^{3}\right)$ \\
\hline \multicolumn{3}{|c|}{ Flow rate } \\
\hline acre-foot per year (acre-ft/yr) & 1,233 & cubic meter per year $\left(\mathrm{m}^{3} / \mathrm{yr}\right)$ \\
\hline acre-foot per year (acre-ft/yr) & 0.001233 & cubic hectometer per year $\left(\mathrm{hm}^{3} / \mathrm{yr}\right)$ \\
\hline \multicolumn{3}{|c|}{ Hydraulic conductivity } \\
\hline foot per day (ft/d) & 0.3048 & meter per day $(\mathrm{m} / \mathrm{d})$ \\
\hline
\end{tabular}


Vertical coordinate information is referenced to the North American Vertical Datum of 1988 (NAVD 88).

Horizontal coordinate information is referenced to the North American Datum of 1983 (NAD 83).

Elevation, as used in this report, refers to distance above the vertical datum

*Transmissivity: The standard unit for transmissivity is cubic foot per day per square foot times foot of aquifer thickness $\left[\left(\mathrm{ft}^{3} / \mathrm{d}\right) / \mathrm{ft}^{2}\right] \mathrm{ft}$. In this report, the mathematically reduced form, foot squared per day $\left(\mathrm{ft}^{2} / \mathrm{d}\right)$, is used for convenience.

\section{Abbreviations}

\begin{tabular}{|c|c|}
\hline ASR & Aquifer-storage-and-recovery system \\
\hline BMP & Basin Management Plan \\
\hline BV & Brown's Valley Bridge \\
\hline CADWR & California Department of Water Resources \\
\hline CCC & California Coastal Commission \\
\hline CDS & Coastal Distribution System \\
\hline $\mathrm{CF}$ & Corralitos at Freedom \\
\hline CIR & Crop irrigation requirement \\
\hline CW & City of Watsonville \\
\hline ENSO & El Nino-Southern Oscillation \\
\hline $\mathrm{ET}_{\mathrm{h}^{\prime}} \mathrm{ET}_{0}$ & Reference evapotranspiration \\
\hline $\mathrm{ET}_{\text {act }}$ & Actual evapotranspiration \\
\hline HS-ASR & Harkins Slough Aquifer-Storage-and-Recovery System \\
\hline H-S & Hargreaves-Samani equation for reference evapotranspiration \\
\hline $\mathrm{K}_{\mathrm{c}}$ & Crop coefficient \\
\hline $\mathrm{K}_{\mathrm{h}}, \mathrm{K}_{\mathrm{v}}$ & Horizontal and vertical hydraulic conductivity \\
\hline MF2K5 & MODFLOW-2005 \\
\hline MF-FMP2 & MODFLOW-2005 version 1.6 with the Farm Process version 2 \\
\hline MNW & Multi-node wells \\
\hline NAMS/PE & North American Monsoon-Pineapple Express \\
\hline PDO & Pacific Decadal Oscillation \\
\hline PVGB & Pajaro Valley Groundwater Basin \\
\hline PVHM & Pajaro Valley Hydrologic Model \\
\hline PVIGSM & Parajo Valley integrated groundwater-surface water model \\
\hline PVWMA & Pajaro Valley Water Management Agency \\
\hline RWF & Recycled-Water Treatment Facility \\
\hline SCWD & Soquel Creek Water District \\
\hline SOSWR & Sum of squared weighted residual \\
\hline TFDR & Total farm delivery requirement \\
\hline USGS & U.S. Geological Survey \\
\hline VR & Varni Road Bridge \\
\hline WBS & Water-balance subregions \\
\hline UCODE-2005 & Universal parameter estimation cod \\
\hline
\end{tabular}




\section{Acknowledgments}

The authors would like to acknowledge the help of several individuals that contributed to the technical content of this study. In particular, Michael Cloud of the County of Santa Cruz Environmental Health Division helped with the compilation of geologic data for the basement rocks and Purisima Formation for the geohydrologic model. Andrew Fisher of the University of California at Santa Cruz contributed streamflow data and geochemical data that helped with the development of the conceptual model and model calibration. The members of the PVWMA Technical Advisory Committee (TAC) provided valuable insight and feedback as the development of the models progressed. Under the leadership of Martin Feeney, this forum became a new focal point for hydrology discussions in the Monterey Bay region, and as such provided additional benefit to the entire region that was not previously available in an otherwise litigious environment. Finally, the authors extend thanks to Lawrence Schneider of the USGS for preparing the technical illustrations. 


\title{
Integrated Hydrologic Model of Pajaro Valley, Santa Cruz and Monterey Counties, California
}

\author{
By R.T. Hanson, Wolfgang Schmid, Claudia C. Faunt, Jonathan Lear, and Brian Lockwood
}

\section{Abstract}

Increasing population, agricultural development (including shifts to more water-intensive crops), and climate variability are placing increasingly larger demands on available groundwater resources in the Pajaro Valley, one of the most productive agricultural regions in the world. This study provided a refined conceptual model, geohydrologic framework, and integrated hydrologic model of the Pajaro Valley. The goal of this study was to produce a model capable of being accurate at scales relevant to water management decisions that are being considered in the revision and updates to the Basin Management Plan (BMP). The Pajaro Valley Hydrologic Model (PVHM) was designed to reproduce the most important natural and human components of the hydrologic system and related climatic factors, permitting an accurate assessment of groundwater conditions and processes that can inform the new BMP and help to improve planning for long-term sustainability of water resources. Model development included a revision of the conceptual model of the flow system, reevaluation of the previous model transformed into MODFLOW, implementation of the new geohydrologic model and conceptual model, and calibration of the transient hydrologic model.

The conceptual model identified inflows and outflows that include the movement and use of water from natural and human components. The groundwater flow system is characterized as a layered geologic sedimentary system through which downward flow is driven by the combined effects of the application of irrigation water at the land surface and the pumping of groundwater from deeper in the system. Overall, groundwater meets most of the agricultural demand in the initial part of the growing season, augmented by precipitation during wet winter and spring seasons. In addition, the amount of groundwater used for irrigation varies from year to year in response to climate variation and can increase dramatically in dry years. Data on agricultural pumpage is a major component of simulated outflow that was previously unavailable; therefore, a coupled farmprocess model was used to estimate historical pumpage for Pajaro Valley by subregion (water-balance subregions) as well as the delivery of surface water to and from the Harkins Slough Aquifer-Storage-and-Recovery System (HS-ASR) and related Coastal Distribution System (CDS) since 2002. The new, integrated hydrologic model includes new waterbalance subregions; delineation of natural, municipal, and agricultural land use; streamflow networks; regions of tile drains; and, the groundwater flow system. The redefinition of the geohydrologic framework and incorporation into the simulation revealed the importance of the confining units at the base of the alluvial deposits and between the upper and lower Aromas Sand for regional groundwater flow.

The PVHM model, using MODFLOW with the Farm Process (MF-FMP2), is capable of being accurate at seasonal to interannual time frames and subregional to valley-wide spatial scales for the assessment of the groundwater hydrologic budget for water years 1964-2009, as well as potential assessment of the BMP components and sustainability analysis of conjunctive use. The model provides a good representation of the regional flow system and the use and movement of water throughout the valley.

Simulated changes in storage over time show that, prior to the 1984-92 dry period, significant withdrawals from storage occurred only during drought years. Since about 1993, growers in the Pajaro Valley have shifted to more water intensive crops, such as strawberries, bushberries, and vegetable row crops, as well as making additional rotational plantings, which have increased demand on limited groundwater resources. Simulated groundwater flow indicates that vertical hydraulic gradients between horizontal layers fluctuate and even reverse in several parts of the basin as recharge and pumpage rates change seasonally and annually. The majority of recharge predominantly enters the Alluvial aquifer system, and along with pumpage and the largest fractions of storage depletion, occurs in the inland regions. Coastal inflow as seawater intrusion replaces much of the potential storage depletion in the coastal regions. The simulated long-term imbalance between inflows and outflows indicates overdraft of the groundwater basin averaging about 12,950 acre-feet per year (acre-ft/yr) over the 46-year period of water years (1964-2009). Annual overdraft varies considerably from year to year, depending on land use, pumpage, and climate conditions. Climatically driven factors can affect inflows, outflows, and water use by as much as a factor of two between wet and dry years. Coastal inflows and outflows vary by year and by aquifer; the net coastal inflow, 
or seawater intrusion, ranges from about 1,000 to more than 6,000 acre-ft/yr. Maps of simulated and measured water-level elevations indicate regions with water levels below sea level in the alluvium and Aromas layers.

Ongoing expansion of local hydrologic monitoring networks indicates the importance of these networks to the understanding of changes in groundwater flow, streamflow, and streamflow infiltration. In particular, the monitoring of streamflow, groundwater pumpage, and groundwater levels throughout the valley not only indicates the state of the resources, but also provides valuable information for model calibration and for model-based evaluation of management actions.

The HS-ASR was simulated for the years 2002-09, and replaced about about 1,290 acre-ft of coastal pumpage. This was combined with the simulation of additional 6,200 acre- $\mathrm{ft}$ of deliveries from supplemental wells, recycled water, and city connection deliveries through the CDS that also supplanted some coastal pumpage. Total simulated deliveries were 7,350 acre-ft of the 7,500 acre-ft of reported deliveries for the period 2002-09. The completed CDS should be capable of delivering about 8.8 million cubic meters (7,150 acre-ft) of water per year to coastal farms within the Pajaro Valley, if all the local supply components were fully available for this purpose. This would represent about 15 percent of the 48,300 acre-ft (59.6 million cubic meters) average agricultural pumpage for the period 2005 to 2009. Combined with the potential capture and reuse of some of the return flows and tile-drain flows, this could represent an almost 70 percent reduction of average overdraft for the entire valley and a large part of the coastal pumpage that induces seawater intrusion.

\section{Introduction}

Pajaro Valley, which is adjacent to Monterey Bay in central California (fig. 1A), is one of the most productive agricultural regions in the world. However, increases in population and transitions to crops that consume additional water have increased the demand for water within the valley. Although a small amount of urban supply is diverted from local creeks, irrigated agriculture is supplied solely by groundwater pumpage, and the source aquifers have been subject to overdraft and related seawater intrusion since the 1940's (Hanson, 2003a). There has been a steady increase of groundwater development in Pajaro Valley, with a five-year average groundwater production of about 55,000 acre- $\mathrm{ft}$ (2005-09). The water levels throughout most of the Pajaro Valley groundwater basin have not significantly recovered since the drought of the late 1980s. As a part of the mitigation process, the Pajaro Valley Water Management Agency (PVWMA) developed a Basin Management Plan (BMP) designed to bring the basin back into hydrologic balance. Components of the BMP included the development of supplemental water supplies, water recycling, managed aquifer recharge, enhanced water use efficiency, and conservation. The final strategy adopted by the PVWMA Board of Directors was called the "Modified BMP 2000 Alternative," and included the following five major projects and programs: 1) Coastal Distribution System (CDS) pipelines; 2) Recycled Water Project; 3) Harkins Slough Recharge Project; 4) 54-inch (54-in.) Import Water Pipeline Project (11,900 acre-ft of imported supply) with local Aquifer-Storage-and-Recovery (ASR) system; and, 5) a Water Conservation Program (Pajaro Valley Water Management Agency, 2007). As part of the BMP, a CDS was constructed to supply water recovered from the Harkins Slough ASR system (HS-ASR). This ASR system was designed to percolate, store, and recover water supplied by a diversion of local runoff from Harkins Slough. Water from other supplemental wells and, later, from the Recycled Water Project also will be delivered through the CDS to supply some of the agricultural water demand near the coast.

The Farm Process (Schmid and others, 2006a) for the U.S. Geological Survey's (USGS) modular groundwater model MODFLOW (Harbaugh, 2005) can simulate the supply and demand components of the BMP and can help water managers assess the effects of the various components of the BMP on the mitigation of the groundwater system overdraft. A regional hydrologic model, the Pajaro Valley Hydrologic Model (PVHM), was developed (as reported herein) to provide water managers with this capability. Delivery priorities are simulated and can be modified on a monthly basis to evaluate different scenarios of prioritization.

The purpose of the study reported here was to create a capability for the PVWMA and regional stakeholders to quantify the potential benefits of various options for bringing the Pajaro Valley Groundwater Basin (PVGB) back into hydrologic balance, as part of a new BMP process (Pajaro Valley Water Management Agency, 2007). A hydrologic flow model capable of being accurate at scales relevant to water management decisions was developed by the USGS in cooperation with the PVWMA for the Pajaro Valley, California.

\section{Purpose and Scope}

This report documents (1) an analysis of the conceptual model, (2) the description of the geohydrologic framework model and hydraulic properties of the aquifer system used in the model, (3) development of a three-dimensional hydrologic flow model and the procedure used to calibrate the hydrologic flow model, and (4) some preliminary analysis of the simulated flow regime with respect to previous models and the BMP components. Because the hydrologic model incorporates time-varying inflows and outflows, this tool can be used to evaluate the effects of temporal changes in recharge and pumping on the hydrologic system and the effects of the BMP components on a regional scale. 


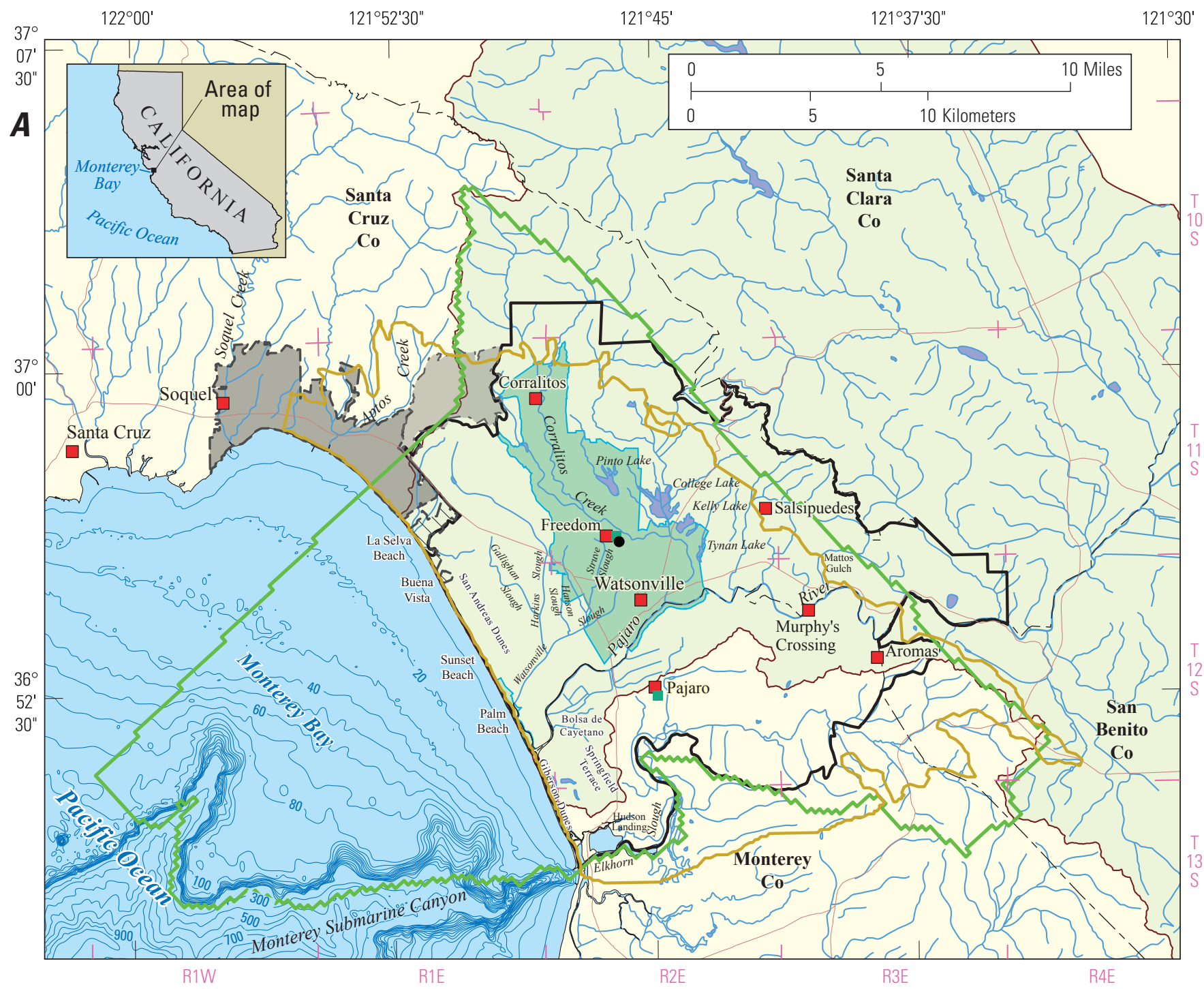

Base from U.S. Geological Survey digital data, 1981-1989.

Universal Transverse Mercator projection, Zone 10, NAD 1983.

Bathymetry data from Monterey Bay Aquarium Research Institute, 2000.

EXPLANATION

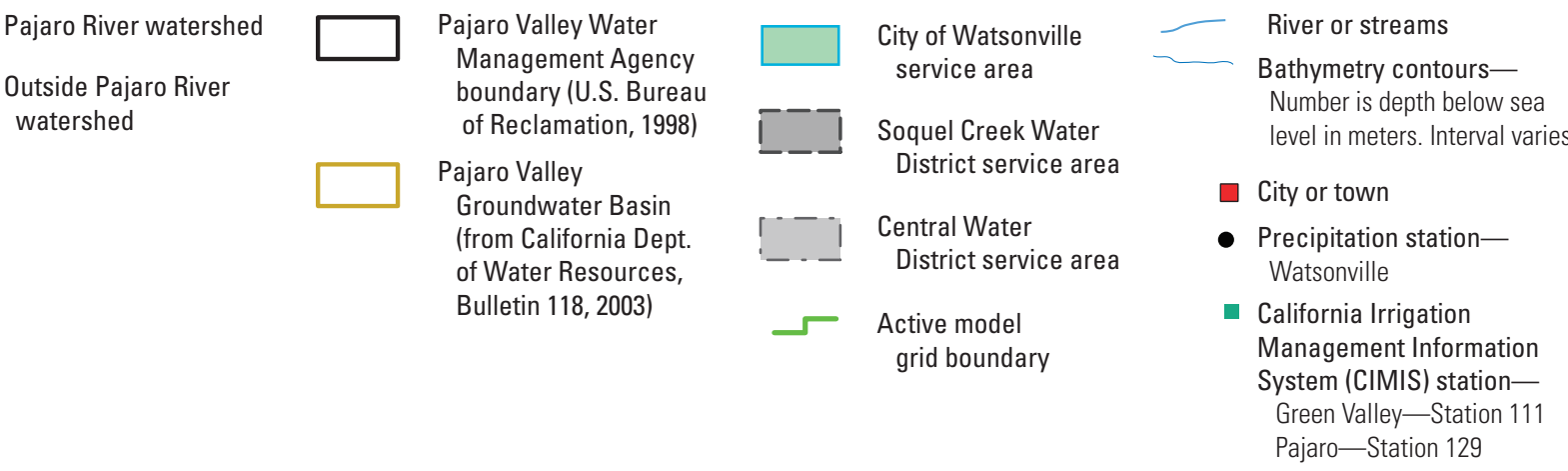

Figure 1. A, Generalized location with place names, watersheds, rivers, water agency boundaries, extent of active model grid, and offshore bathymetry; and $B$, detailed location map with model grid, Pajaro Valley, California. 

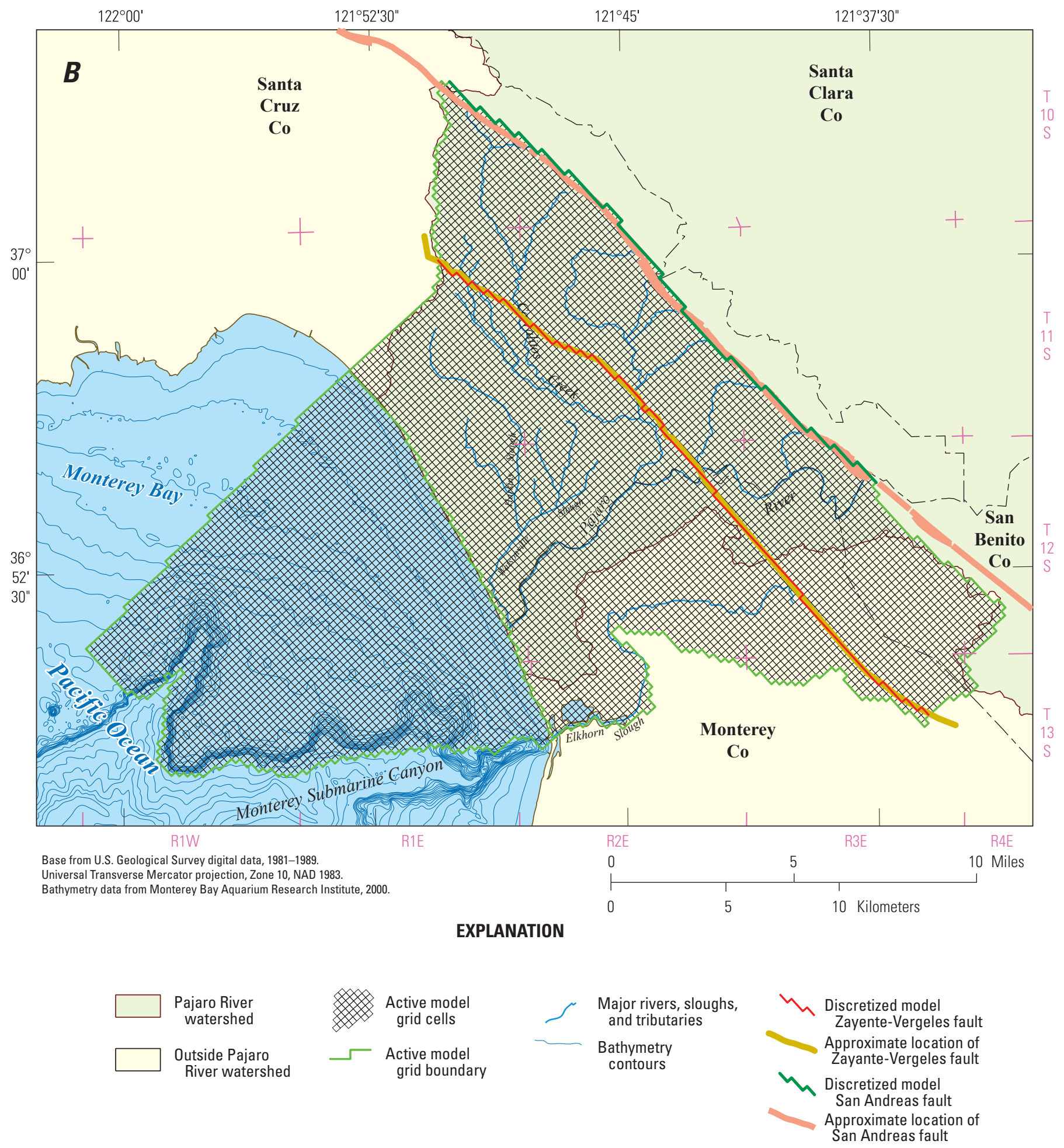

Figure 1. - Continued 


\section{Approach}

The creation of a new hydrologic model of the Pajaro Valley required the reanalysis of the original conceptual model and the geohydrologic framework, and the estimation of the components of the hydrologic cycle. The conceptual model was realigned with newer information about recharge, seawater intrusion, and streamflow infiltration (Hanson, 2003a, b; Hatch and others, 2006; Ruehl and others, 2007).

The reanalysis of the geohydrologic framework required the remapping of geologic surfaces and the integration and reconciliation of geologic information from recent wells and investigations with earlier data. The drillers' logs from selected wells were digitized to create estimates of hydraulic properties on the basis of percentages of coarse- and finegrained material within each geohydrologic unit on a cell-bycell basis.

The PVHM was constructed on the basis of the new conceptual and geohydrologic models to simulate the flow and use of water in the Pajaro Valley for the period of October, 1963 to December, 2009. This model employs new layering, revised values for inflows and outflows, and detailed representation of the more recent BMP projects such as the HS-ASR system and CDS. The new model includes both the landward and submarine portions of the aquifer system (fig. 1B).

\section{Description of Study Area}

Pajaro Valley is a 237- $\mathrm{mi}^{2}$ coastal part of the Pajaro River watershed within the PVWMA boundary in the southern part of Santa Cruz County and the northern part of Monterey County (the Pajaro River is the county boundary). The valley is the coastal part of the larger Pajaro River watershed that extends further landward into San Benito and Santa Clara Counties (fig. 1A). The valley is drained by the Pajaro River and its tributaries, of which Corralitos Creek is the largest, and the watershed lies along Monterey Bay south of the city of Santa Cruz and north of Elkhorn Slough and its offshore extension, Monterey submarine canyon. The valley has been developed predominantly for agriculture since the late $1800 \mathrm{~s}$ but also contains the city of Watsonville (CW) and other small towns and suburban areas. The PVWMA service area encompasses about 70,000 acres, of which about 40 percent is used for agriculture, about 47 percent is natural vegetation, and 13 percent is primarily urban land. The valley portion of the PVWMA area west of the San Andreas Fault comprises about $124 \mathrm{mi}^{2}$, about half of which is prime farm land that relies almost exclusively on groundwater for its water supply (Lear, 2001). The aquifers extend offshore where they crop out along the seafloor and along the northern sides of Monterey submarine canyon (fig. $1 B$ ). The aquifers are thus susceptible to seawater intrusion when the aggregate of outflows (including pumpage) exceeds the aggregate of inflows for an extended period, leading to groundwater overdraft (Hanson, 2003a,b).

\section{Water-Balance Subregions}

The assessment of sustainable yield and analysis of the BMP components relative to the hydrologic cycle (fig. $2 A$ ) requires discretization of Pajaro Valley into subregions that can be used to estimate the water balance of land use, streamflow, and groundwater (fig. 2B). These water-balance subregions (WBSs) represent the rediscretization of the water-balance subregions delineated in the previous regional hydrologic model (Hanson, 2003a, fig. 1). For the purposes of this report, the WBSs represent accounting units for water use, movement, and consumption. The WBSs are analogous to "virtual farms" that are used to calculate the overall supply and demand components through time. Many of these WBSs represent groups of local watersheds, groups of actual farms, or other unique supply and demand subregions. They share similar exterior boundaries with the previous revised Pajaro Valley integrated groundwater-surface water model (PVIGSM) with the exception of the CW WBS (subregion 4), which was realigned to represent the urban areas of the CW. Similarly, new WBSs were delineated that are coincident with the parts of neighboring Soquel Creek and Central Water Districts along the northern part of the active modeled region (fig. 2B). The previous coastal WBSs were also subdivided into subregions that received water from the CDS as of 2009, and those subregions that are not scheduled to receive water from the CDS (fig. 2B). The four model cells that represent the ASR operation and related supplemental and blend wells were also made a separate WBS (WBS 13, 14, 15, 24, fig. 2B). The transition from the previous water-balance subregions to the new WBSs is summarized in table 1.

For further analysis, these subregions were grouped into eight water-balance regions (WBRs, fig. 2C, table 1) that represent the inland parts of Santa Cruz and Monterey Counties, the coastal regions served by the CDS and nonCDS subregions in Santa Cruz and Monterey Counties, the Santa Cruz County Water Districts, and the four cells that represent the components of the ASR system. The PVWMA is represented by two WBSs that represent the inland and coastal parts of the valley. These subregions and regions represent a combination of the watersheds and water delivery areas within Pajaro Valley that can be used to assess the inflow and outflow components of the hydrologic cycle with the project components of the BMP (fig. $2 A$ ). 


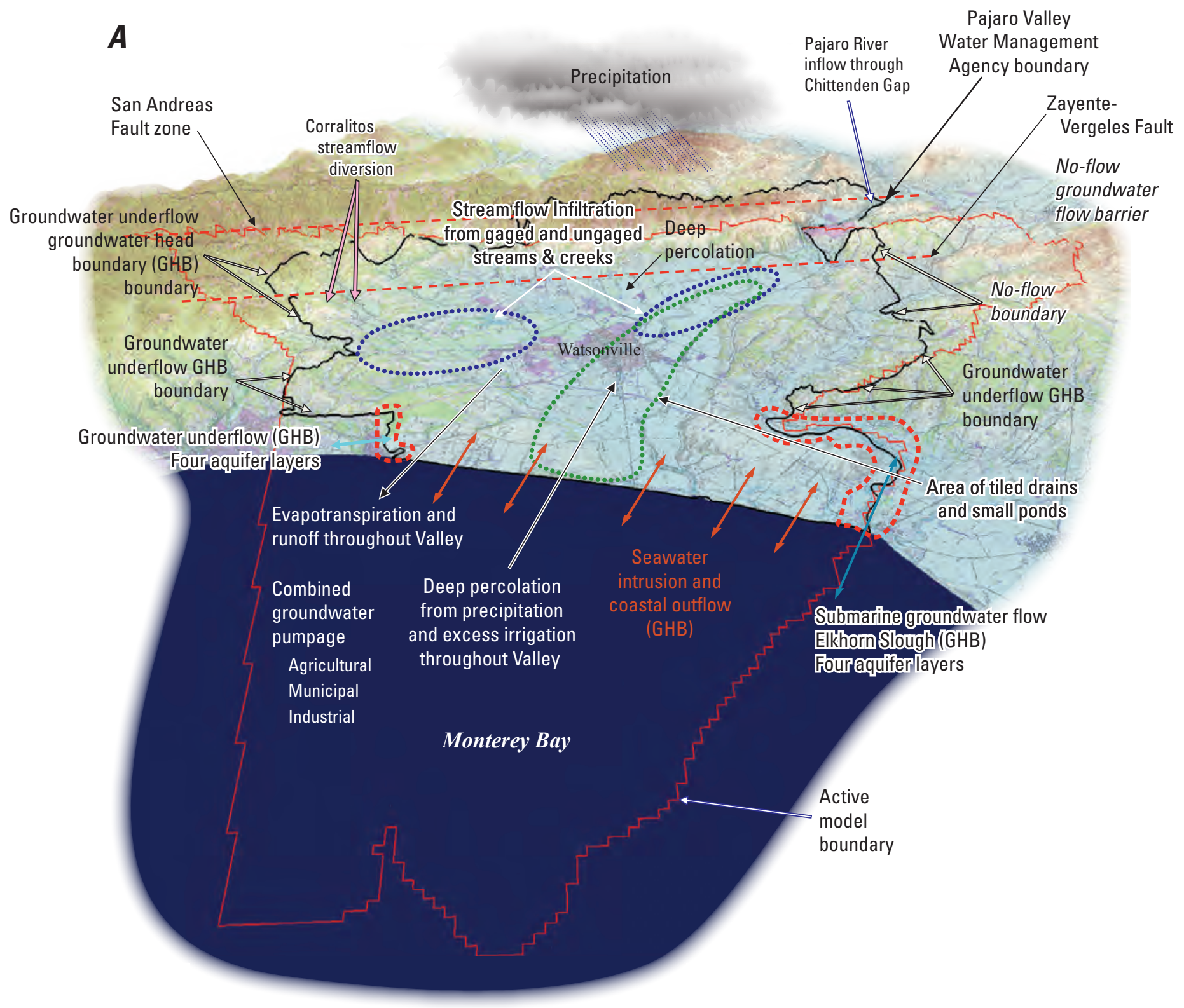

Figure 2. A, Oblique, quasi-three-dimensional diagram showing conceptual model for the hydrologic cycle; $B$, the Pajaro Valley Hydrologic Model model region, water-balance subregions and water districts, and area of seawater intrusion; $C$, regional groups of water-balance subregions in Pajaro Valley, California. [ASR, aquifer-storage-and-recovery system; CSD, Coastal Distribution System] 


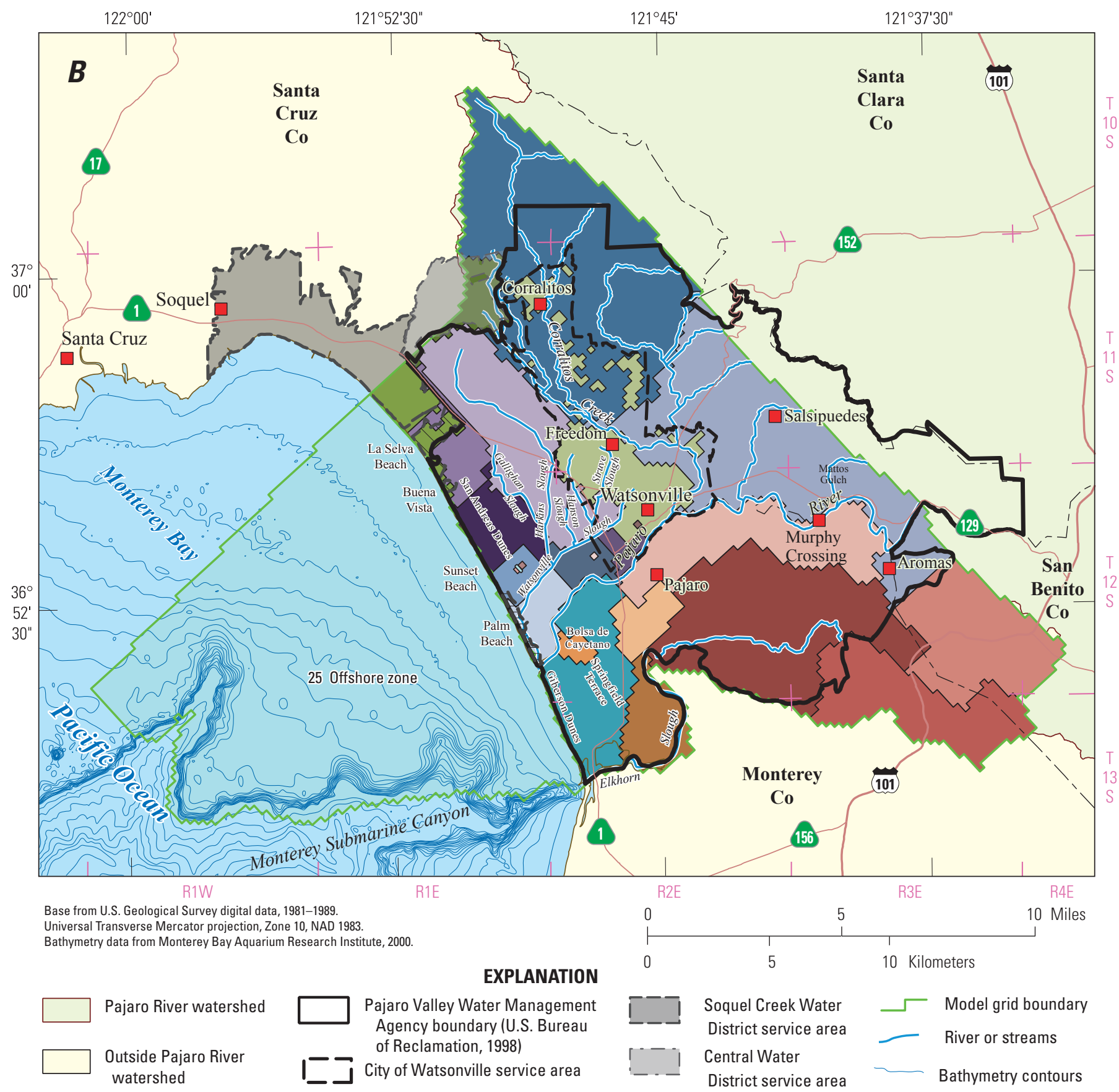

Water-balance regions (WBR) with subregion (WBS) identifiers-

\begin{tabular}{|c|c|}
\hline anta Cruz County inland & Monterey County inland \\
\hline 1 Corralitos & 6 Pajaro \\
\hline 5 Salsipudes & 7 Granite Ridge \\
\hline anta Cruz County water districts & 11 Highlands South \\
\hline $\begin{aligned} 4 & \text { Watsonville } \\
21 & \text { Soquel Creek Water District }\end{aligned}$ & Santa Cruz County coast CDS \\
\hline 23 Central Water District & \begin{tabular}{|l} 
\\
16 Pajaro River Mouth \\
16 San Andreas \\
17 Beach Road
\end{tabular} \\
\hline
\end{tabular}

Santa Cruz County coast non-CDS

$\square 2$ Harkins Slough

3 San Andreas

10 Beach Road

22 San Andreas

Monterey County coast CDS

9 Springfield Terrace

6 San Andreas

17 Beach Road
Monterey County coast non-CDS

$\square 18$ Springfield Terrace E

19 Springfield Terrace W

20 Springfield Terrace SE

\section{ASR system}

$\square 13$ CDS-City Connection Supplemental

14 San Andreas Dunes ASR

$\square 15$ San Andreas Dunes recovery well 24 City of Watsonville blend wells

Figure 2. - Continued 


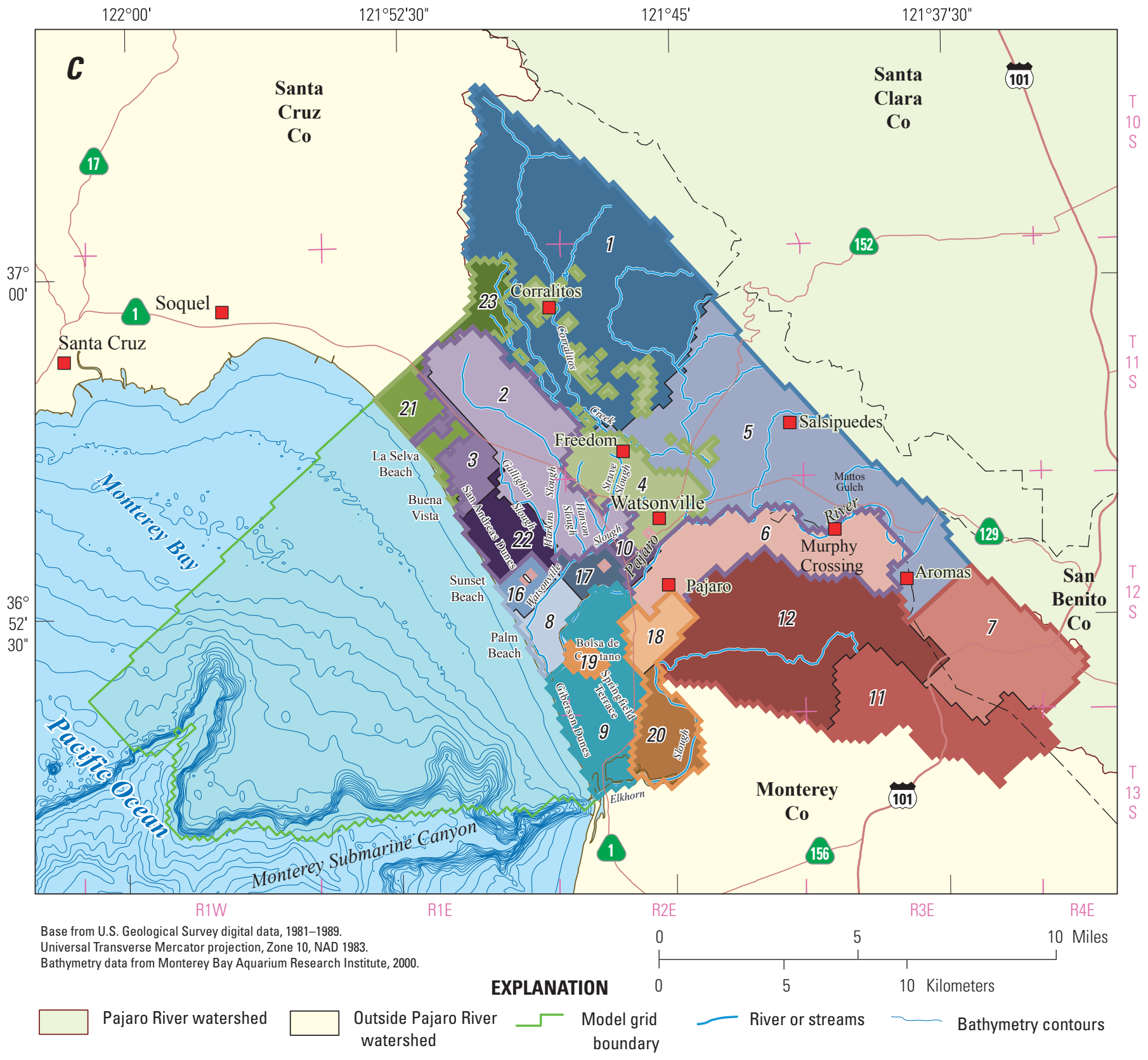

Water-balance regions (WBR) with subregion (WBS) identifiers-

INLAND
$\square$ Santa Cruz County inland
1 Corralitos
5 Salsipudes
Monterey County inland
6 Pajaro
7 Granite Ridge
11 Highlands South
12 Highlands North
Santa Cruz County water districts
4 Watsonville
23 Central Water District

$\square$ Santa Cruz County coast non-CDS
2 Harkins Slough
3 San Andreas
10 Beach Road
22 San Andreas
Santa Cruz County coast CDS
8 Pajaro River Mouth
16 San Andreas
17 Beach Road

COASTAL

$\square$ Monterey County coast CDS

9 Springfield Terrace

$\square$ Monterey County coast non-CDS

18 Springfield Terrace E

19 Springfield Terrace W

20 Springfield Terrace SE

$\square$ Santa Cruz County water districts

21 Soquel Creek Water District

OTHER
$\square$ ASR system
13 CDS-City Connection
Supplemental
14 San Andreas Dunes ASR
15 San Andreas Dunes
recovery well
24 City of Watsonville
blend wells
$\square$ Offshore

25 Offshore zone

Figure 2. - Continued 
Table 1. Summary of water-balance subregions (WBS) and grouped water balance regions (WBR) for the Pajaro Valley Hydrologic Model (PVHM), Pajaro Valley, California.

[—, no data; CDS, Coastal Distribution System; PVWMA, Pajaro Valley Water Management Agency; ASR, Aquifer-storage-and-recovery system; PVIGSM, Parajo Valley integrated groundwater-surface water model]

\begin{tabular}{|c|c|c|c|c|c|}
\hline $\begin{array}{l}\text { Previous } \\
\text { water-balance } \\
\text { subregion } \\
\text { number }^{1}\end{array}$ & $\begin{array}{c}\text { Current (PVHM) } \\
\text { water-balance } \\
\text { subregion } \\
\text { number }\end{array}$ & $\begin{array}{c}\text { Water-balance } \\
\text { subregion } \\
\text { name } \\
(\text { fig. } 2 A)\end{array}$ & $\begin{array}{c}\text { Water-balance } \\
\text { regions } \\
(\text { figs. } 2 B, C)\end{array}$ & Description & $\begin{array}{l}\text { Additional } \\
\text { remarks }\end{array}$ \\
\hline 3 & 3 & San Andreas & $\begin{array}{c}\text { Santa Cruz County } \\
\text { Coast non-CDS }\end{array}$ & $\begin{array}{l}\text { Northern PVWMA San } \\
\text { Andreas }\end{array}$ & Beyond CDS pipeline extent \\
\hline 4 & 4 & Watsonville & $\begin{array}{l}\text { Santa Cruz County } \\
\text { Water Districts }\end{array}$ & City of Watsonville & $\begin{array}{l}\text { Revised to include all urban } \\
\text { areas within City limits }\end{array}$ \\
\hline 5 & 5 & Salsipuedes & $\begin{array}{l}\text { Santa Cruz County } \\
\text { Inland }\end{array}$ & $\begin{array}{l}\text { Tributaries to Corralitos } \\
\text { Creek and Pajaro River }\end{array}$ & - \\
\hline 7 & 7 & Granite Ridge & $\begin{array}{l}\text { Monterey County } \\
\text { Inland }\end{array}$ & - & - \\
\hline 8 & 8 & $\begin{array}{l}\text { Pajaro River Mouth } \\
\text { CDS }\end{array}$ & $\begin{array}{l}\text { Santa Cruz County } \\
\text { Coast CDS }\end{array}$ & $\begin{array}{l}\text { Subregion of subregion } 8 \\
\text { from previous model }\end{array}$ & $\begin{array}{l}\text { Region with CDS } \\
\text { connections }\end{array}$ \\
\hline 9 & 9 & $\begin{array}{l}\text { Springfield Terrace } \\
\text { CDS }\end{array}$ & $\begin{array}{l}\text { Monterey County } \\
\text { Coast CDS }\end{array}$ & $\begin{array}{l}\text { Subregion of subregion } 9 \\
\text { from previous model }\end{array}$ & $\begin{array}{l}\text { Region with CDS } \\
\text { connections }\end{array}$ \\
\hline 10 & 10 & $\begin{array}{l}\text { Beach Road } \\
\text { non-CDS }\end{array}$ & $\begin{array}{c}\text { Santa Cruz County } \\
\text { Coast non-CDS }\end{array}$ & Lower Pajaro Valley region & $\begin{array}{l}\text { Region without CDS } \\
\text { connections }\end{array}$ \\
\hline 11 & 11 & Highlands South & $\begin{array}{l}\text { Monterey County } \\
\text { Inland }\end{array}$ & - & $\begin{array}{l}\text { Also referred to as the } \\
\text { Carneros Hills region }\end{array}$ \\
\hline - & 15 & $\begin{array}{l}\text { San Andreas Dunes } \\
\text { Recovery Wells }\end{array}$ & $\begin{array}{c}\text { ASR_CDS_ } \\
\text { System }\end{array}$ & $\begin{array}{l}\text { Part of Subregion } 3 \text { from } \\
\text { previous model }\end{array}$ & - \\
\hline - & 16 & San Andreas CDS & $\begin{array}{l}\text { Santa Cruz County } \\
\text { Coast CDS }\end{array}$ & $\begin{array}{l}\text { Part of Subregion } 3 \text { from } \\
\text { previous model }\end{array}$ & $\begin{array}{l}\text { Region with CDS } \\
\text { connections }\end{array}$ \\
\hline - & 17 & Beach Road CDS & $\begin{array}{l}\text { Santa Cruz County } \\
\text { Coast CDS }\end{array}$ & $\begin{array}{l}\text { Part of Subregion } 10 \text { from } \\
\text { previous model }\end{array}$ & $\begin{array}{l}\text { Region with CDS } \\
\text { connections }\end{array}$ \\
\hline - & 18 & $\begin{array}{l}\text { Springfield Terrace } \\
\text { East non-CDS }\end{array}$ & $\begin{array}{l}\text { Monterey County } \\
\text { Coast non-CDS }\end{array}$ & $\begin{array}{l}\text { Subregion of subregion } 9 \\
\text { from previous model }\end{array}$ & $\begin{array}{l}\text { Region with declined CDS } \\
\text { connections }\end{array}$ \\
\hline - & 19 & $\begin{array}{l}\text { Springfield Terrace } \\
\text { West non-CDS }\end{array}$ & $\begin{array}{l}\text { Monterey County } \\
\text { Coast non-CDS }\end{array}$ & $\begin{array}{l}\text { Subregion of subregion } 9 \\
\text { from previous model }\end{array}$ & $\begin{array}{l}\text { Region with declined CDS } \\
\text { connections }\end{array}$ \\
\hline - & 20 & $\begin{array}{l}\text { Springfield Terrace } \\
\text { Southeast non- } \\
\text { CDS }\end{array}$ & $\begin{array}{l}\text { Monterey County } \\
\text { Coast non-CDS }\end{array}$ & $\begin{array}{l}\text { Subregion of subregion } 9 \\
\text { from previous model }\end{array}$ & $\begin{array}{l}\text { Region with declined CDS } \\
\text { connections }\end{array}$ \\
\hline
\end{tabular}


Table 1. Summary of water-balance subregions (WBS) and grouped water balance regions (WBR) for the Pajaro Valley Hydrologic Model (PVHM), Pajaro Valley, California.-Continued

[-, no data; CDS, Coastal Distribution System; PVWMA, Pajaro Valley Water Management Agency; ASR, Aquifer-storage-and-recovery system; PVIGSM, Parajo Valley integrated groundwater-surface water model]

\begin{tabular}{|c|c|c|c|c|c|}
\hline $\begin{array}{l}\text { Previous } \\
\text { water-balance } \\
\text { subregion } \\
\text { number }\end{array}$ & $\begin{array}{l}\text { Current (PVHM) } \\
\text { water-balance } \\
\text { subregion } \\
\text { number }\end{array}$ & $\begin{array}{c}\text { Water-balance } \\
\text { subregion } \\
\text { name } \\
(f i g .2 A)\end{array}$ & $\begin{array}{c}\text { Water-balance } \\
\text { regions } \\
(\text { figs. } 2 B, C)\end{array}$ & Description & $\begin{array}{l}\text { Additional } \\
\text { remarks }\end{array}$ \\
\hline- & 22 & $\begin{array}{c}\text { San Andreas } \\
\text { non-CDS }\end{array}$ & $\begin{array}{l}\text { Santa Cruz County } \\
\text { Coast non-CDS }\end{array}$ & $\begin{array}{l}\text { Part of Subregion } 3 \text { from } \\
\text { previous model }\end{array}$ & $\begin{array}{l}\text { Region with declined CDS } \\
\text { connections }\end{array}$ \\
\hline- & 24 & $\begin{array}{l}\text { City of Watsonville } \\
\text { Blend Wells }\end{array}$ & $\begin{array}{l}\text { ASR_CDS_- } \\
\text { System }\end{array}$ & $\begin{array}{l}\text { Part of Subregion } 4 \text { from } \\
\text { previous model }\end{array}$ & $\begin{array}{l}\text { City Well Blending input } \\
\text { Wells } 10 \text { and } 15\end{array}$ \\
\hline 13 & 25 & $\begin{array}{l}\text { Monterey Bay } \\
\text { offshore }\end{array}$ & Offshore & $\begin{array}{l}\text { Subregion } 13 \text { from previous } \\
\text { model }\end{array}$ & $\begin{array}{l}\text { Previously Subregion } \\
13 \text { was Monterey Bay } \\
\text { offshore in PVIGSM }\end{array}$ \\
\hline
\end{tabular}

${ }^{1}$ Original water-balance subregions summarized by Tegavhi and others (1999).

\section{Geohydrologic Framework}

The hydrogeologic framework of Pajaro Valley was estimated through a reevaluation and synthesis of the geology from previous studies that resulted in a simplified grouping of geologic units into hydrogeologic units. The onshore and offshore outcrops and extent of the major geologic units is shown in figure $3 \mathrm{~A}$. The Holocene and late Pleistocene alluvial deposits overlie the Aromas Sand (also referred to as the Aromas) of Pleistocene age that in turn overlie the Pliocene Purisima Formation (Allen, 1946; California State Water Resources Board, 1953; Hickey, 1968; Clark, 1981; Dupre, 1975, 1990; Brown and Caldwell, 1976; Brabb and others, 1997; Wagner and Pridmore, 1991; Hanson, 2003a; Powell and others, 2008). Additional offshore definition of outcrops (Green, 1970; Brabb and others, 1997; Wagner and Pridmore, 1991; Eittreim and others, 2000, 2002) also was compiled and merged with terrestrial geologic maps and cross sections (Allen, 1946; Muir, 1972, 1974; WoodwardClyde Consultants, 1983; FWI, 1995, 1996; Luhdorff and Scalmanini, 1987a,b, 1988; Teghavi and Smith, 1999e; Johnson and others, 2004; Johnson, 2006). With more than 90 separate mapped units in Pajaro Valley, grouping of units was necessary to aggregate the geology of the Pajaro Basin into a simplified layering system acceptable for a hydrologic flow model. The hydrogeologic framework that was used to represent the six discrete hydrologic model layers, as well as the aquifers and confining units, that included:
1. Two layers of the alluvial deposits representing an alluvial deposit layer and a basal fine-grained confining unit;

2. Three layers of the Aromas Sand representing the upper Aromas, an upper Aromas basal fine-grained confining unit, and a lower Aromas unit; and

3. One layer representing a combination of the Purisima Formation and other minor pre-Pliocene bedrock units.

The revised hydrogeologic units were designated on the basis of existing geologic maps and reports, cross sections, geophysical logs from water wells and oil and gas wells, gravity maps, and drillers' logs. The analyses of these data resulted in the delineation of new upper surfaces that may represent a composite of erosional unconformities for each of these units.

Many different alluvial deposits were grouped to create a contiguous uppermost Alluvial aquifer layer of the model. Deposits that were grouped included the Older Alluvium, Landslide Deposits, Undivided Terrace Deposits, Marine Terrace Deposits, Watsonville Terrace Deposits, Beach Sands, Basin Deposits, Older Dune Sands, and Alluvial Fan Deposits (Wagner and Pridmore, 1991). The alluvial deposits and related basal fine-grained confining layer (refered to as the basal confining layer in this report) are of variable spatial extent and range in thickness from about 15 to 380 feet (ft) and 15 to $55 \mathrm{ft}$, respectively (figs. $3 B, C$ ). The extent of the basal fine-grained confining unit was systematically picked 
from the discontinuity in the histogram of the distribution of percent coarse-grained material (see discussion on Textural Analysis later in report). This basal confining layer was identified using an empirically derived threshold value of greater than 33 percent fine-grained material. The fine-grained basal confining unit may comprise deposits from one or more periods of sea-level high stand during the Pleistocene, or may represent overbank (flood) deposits.

The Aromas Sand of late Quaternary age is composed of friable, quartzose, well-sorted brown to red sands that generally are medium-grained and weakly cemented with iron oxide (Johnson and others, 1988) with clayey interbeds and poorly sorted medium-grained gravel (Allen, 1946). These units collectively were reported to range in thickness from $100 \mathrm{ft}$ in the foothills, to nearly $900 \mathrm{ft}$ below sea level near the mouth of the Pajaro River (Allen, 1946). The Aromas Sand, considered the primary water-bearing unit of the valley, were originally interpreted to consist of upper eolian and lower fluvial sand units that are separated by confining layers of interbedded clays and silty clay (Johnson and others, 1988). All mapped Aromas outcrops, which included eolian, fluvial, and undifferentiated facies, were grouped for purposes of the model and study. The eolian facies outcrops in the western region of the model area, whereas the fluvial facies outcrops in the eastern region of the model area.

For this model, the Aromas Sand was split into three units that are represented by the upper Aromas, a finegrained confining unit below the upper Aromas, and the lower Aromas. The upper Aromas constitute predominantly terrestrial sedimentary deposits that were further subdivided into an eastward fluvial facies and a westward aeolian facies. The top of the upper Aromas was estimated on the basis of analysis of geophysical logs of recently drilled wells and from cross sections derived from previous studies. This unit was estimated to range in thickness from about 15 to $500 \mathrm{ft}$ (fig. 3B). The fine-grained confining unit between the upper and lower Aromas may represent the fining-upward portion of a glacial-cycle sedimentary sequence during a transition from predominantly marine sediments in the lower Aromas to predominantly terrestrial sediments of the upper Aromas. The top of this fine-grained confining unit was estimated by inspection of geophysical logs. The thickness of the fine-grained layer was determined systematically using an empirically derived threshold value of 16 percent fine-grained material identified from the discontinuity in the histogram of the percent fine-grained material. The thickness of this fine-grained unit ranges from about $15 \mathrm{ft}$ to about $115 \mathrm{ft}$ thick (fig. 3B). Similar to the alluvial confining unit, this unit is not present everywhere. The lower Aromas consists predominantly of marine sediments but represents a mix of marine sediments in the western parts of the valley and fluvial sediments in the eastern part of the valley. This unit ranges in thickness from about $15 \mathrm{ft}$ to $1,000 \mathrm{ft}$ (figs. $3 B, C$ ).

The Pursima Formation as defined to the north (Hydrometrics, 2009; Environmental Science Association, 2006; Powell and others, 2008; Johnson and others, 2004; Essaid, 1992) and to the south (Hanson and others, 2002) includes about six sedimentary sequences of near- and farshore marine deposits of Pliocene age, with the last sequence possibly representing some terrestrial sediments (the $\mathrm{F}$ member). The Purisima Formation was characterized in Pajaro Valley from geologic reports and maps (Dupre, 1975, 1990; Wagner and Pridmore, 1991; Wagner and others, 2000; Eittreim and others, 2000, 2002), geophysical logs from water wells and oil and gas wells, gravity maps (Robert Jachens, USGS, written commun, 2006), and earthquake simulations (Jachens, 2006). The unconformity representing the top of the Purisima Formation was estimated by inspection of geophysical logs and relations to previous cross sections. Outcrops of Plio-Pleisotcene continental deposits and Butano Sandstone were grouped with Purisima outcrops. These outcrops are present in the eastern and north-eastern boundary of the model.

The top of the basement was identified from inspection of geophysical logs from oil and gas prospecting wells, deep water wells, gravity maps, and geologic maps and cross sections (Michael Cloud, Santa Cruz County Environmental Department, written commun., 2007). The basement rocks are a combination of granite and Oligocene-aged rocks. The Miocene-aged gabroic and granitic rocks were grouped with the granite pluton on the geologic maps. These units crop out in the south eastern region of the model area and constitute the bedrock of the entire geologic framework model. The Oligocene-aged rocks were also grouped with the basement rocks, which included the Pineconte Formation, Red Beds, and unnamed volcanic rocks of Miocene age. These rocks occur primarily in the northwestern and southeastern parts of the Valley. The bedrock occurs at shallower depths near the coast and just west of the Santa Cruz Basin portion of Pajaro Valley; this may coincide with the trace of the Zayente-Vergeles Fault (herein referred to as the Zayante Fault). East of the fault, these rocks are shallowest where they offset against the lower Purisima (fig. 3C). The lower parts of the Purisima and the bedrock may be partly offset by this fault. For the purposes of the layering in the hydrologic model, the upper 100 meters (m; about $330 \mathrm{ft}$ ) of the bedrock was included with the Purisima Formation as part of the lowermost layer (layer 6) in the southeastern part of the model where the bedrock crops out. This bedrock zone included in the southeastern part of the model was limited to no more than the uppermost 1,640 ft of thickness (figs. 3B, C). 


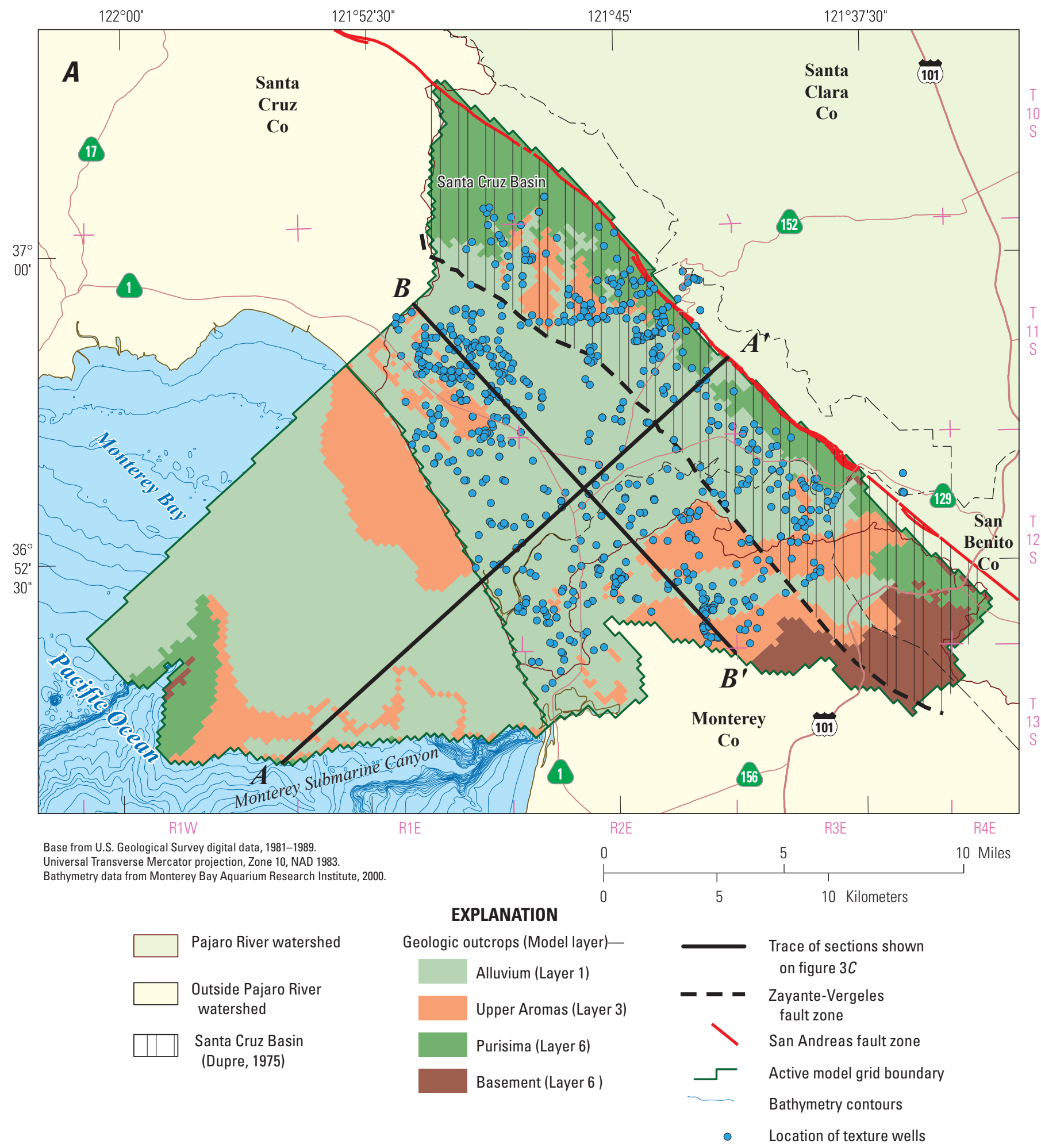

Figure 3. Generalized $A$, outcrops of geologic units and major faults within model grid; $B$, estimated thickness of each of the hydrogeologic model layers; and $C$, hydrogeologic sections ( $A-A^{\prime}$ and $\left.B-B^{\prime}\right)$ of hydrogeologic units used as model layers in the Pajaro Valley, California. 


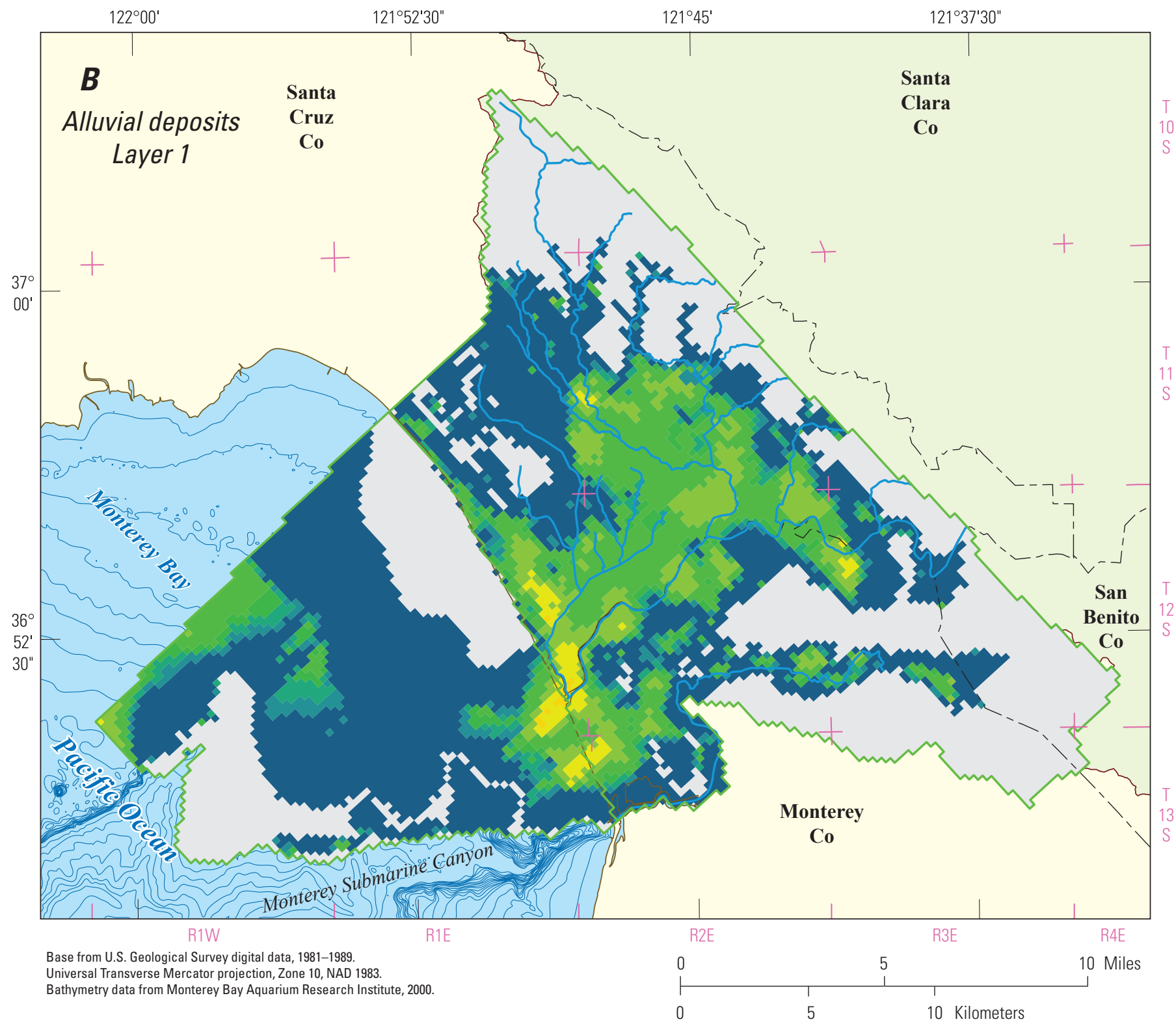

EXPLANATION

Pajaro River watershed

Outside Pajaro River watershed

$\sqsubset$ Model grid boundary

River or streams

Bathymetry contours
Alluvium thickness, in meters (feet)

Less than or equal to 5 (16.4)

Greater than 5 to 10 (16.4 to 32.8 )

Greater than 10 to 15 (32.8 to 49.2 )

Greater than 15 to 20 (49.2 to 65.6 )

Greater than 20 to 25 (65.6 to 82.0)

Greater than 25 to 50 (82.0 to 164 )

Greater than 50 to 75 (164 to 246)
Greater than 75 to 100 (246 to 328 )

Greater than 100 to 116 (328 to 381)

Not present

Figure 3. - Continued 


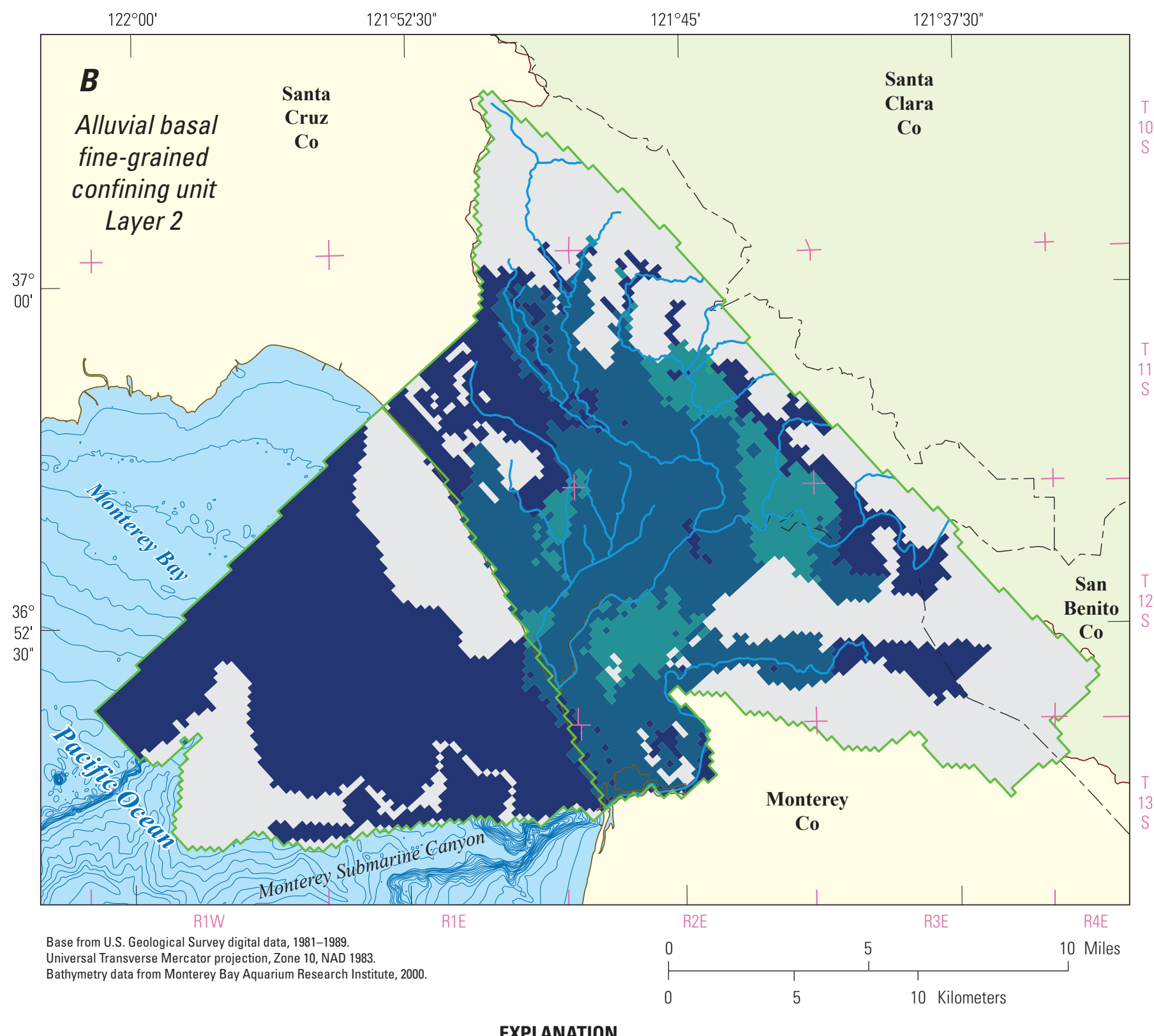

\section{EXPLANATION}

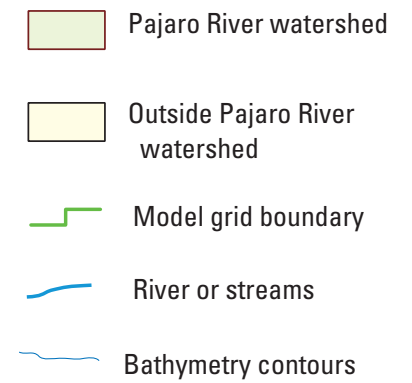

Alluvial basal fine-grained confining unit thickness, in meters (feet)

Less than or equal to 5 (16.4)

Greater than 5 to 10 (16.4 to 32.8 )

Greater than 10 to 15 (32.8 to 49.2 )

Greater than 15 to 16 (49.2 to 53 )

Not present

Figure 3. - Continued 


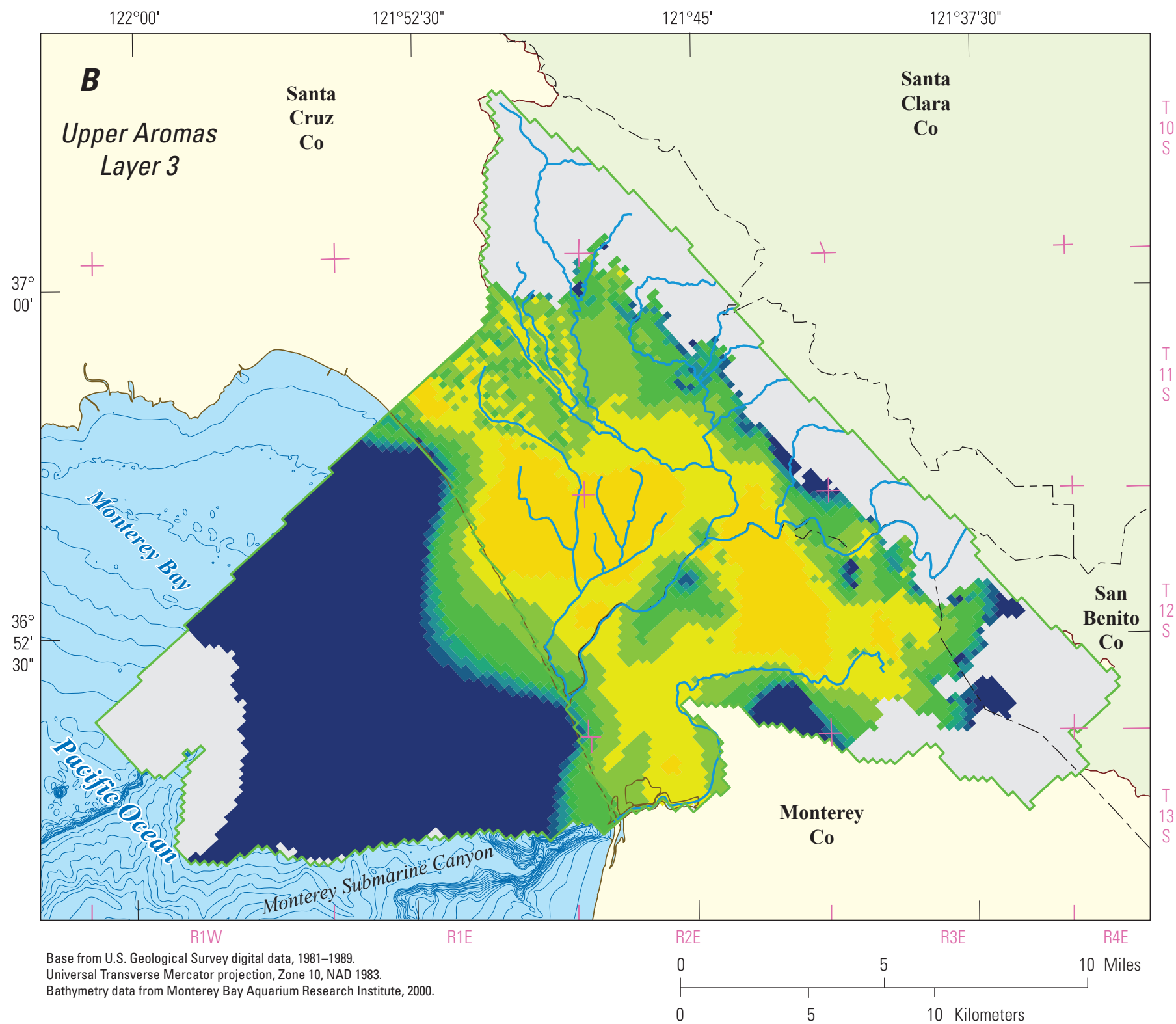

\section{EXPLANATION}

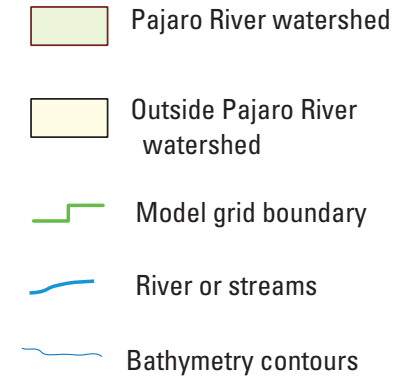

Upper Aromas thickness, in meters (feet)

Less than or equal to 5 (16.4)

Greater than 5 to 10 (16.4 to 32.8 )

Greater than 10 to 15 (32.8 to 49.2)

Greater than 15 to 20 (49.2 to 65.6)

Greater than 75 to 100 (246 to 328 )

Greater than 100 to 153 (328 to 502)

Greater than 15 to 20 (49.2 to 65.6)

Not present

Greater than 20 to 25 (65.6 to 82.0 )

Greater than 25 to 50 (82.0 to 164 )

Greater than 50 to 75 (164 to 246 )

\section{Not present}

Figure 3. - Continued 


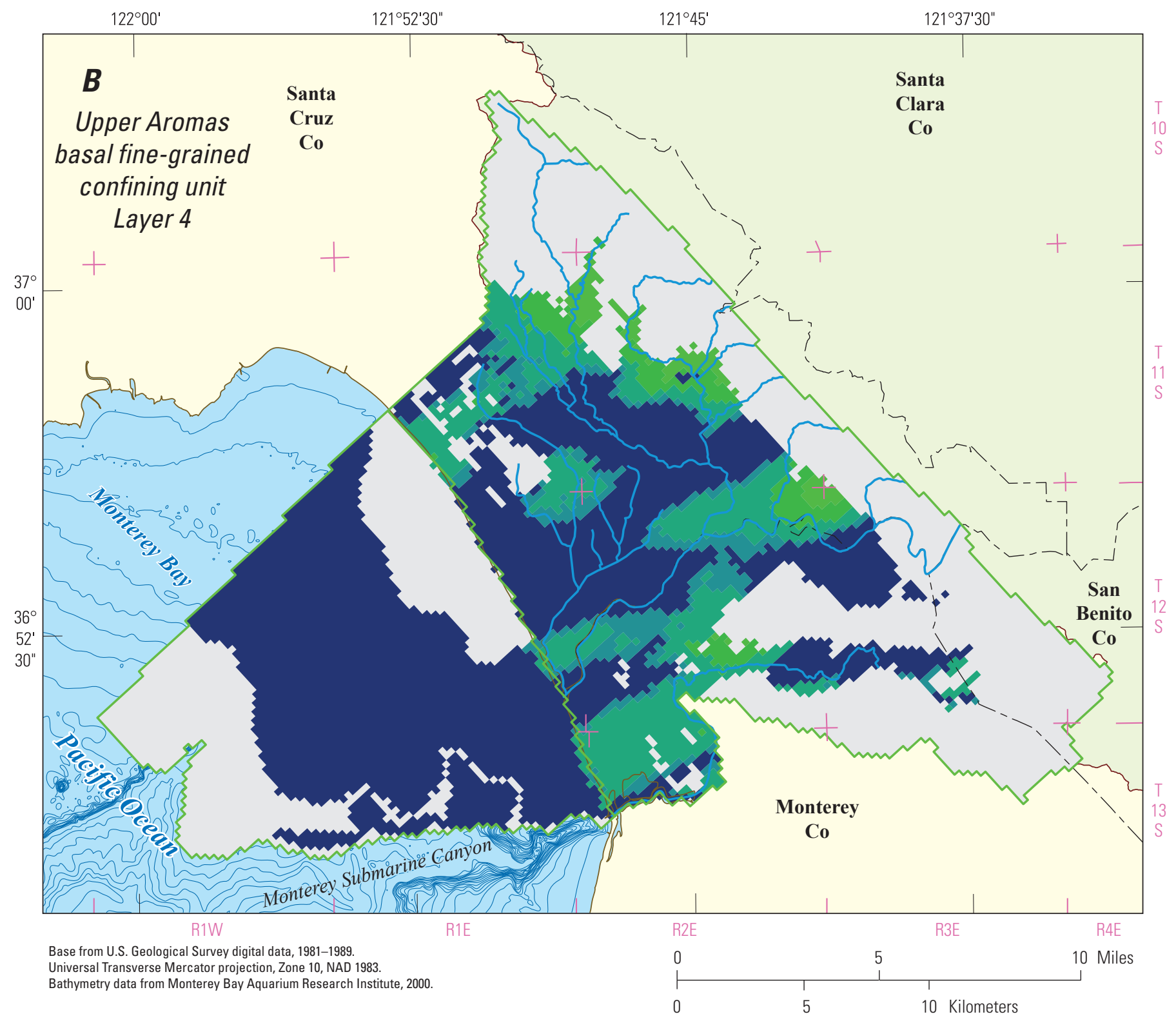

EXPLANATION

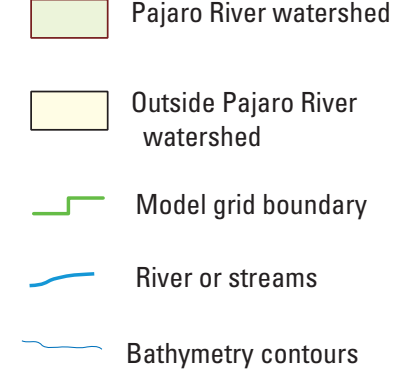

Upper Aromas basal fine-grained

confining unit thickness, in meters (feet)

Less than or equal to 5 (16.4)

Greater than 5 to 10 (16.4 to 32.8$)$

Greater than 10 to 15 (32.8 to 49.2$)$

Greater than 15 to 20 (49.2 to 65.6 )

Greater than 20 to 25 (65.6 to 82.0)

Greater than 25 to 35 (82.0 to 115 )

Not present

Figure 3. - Continued 


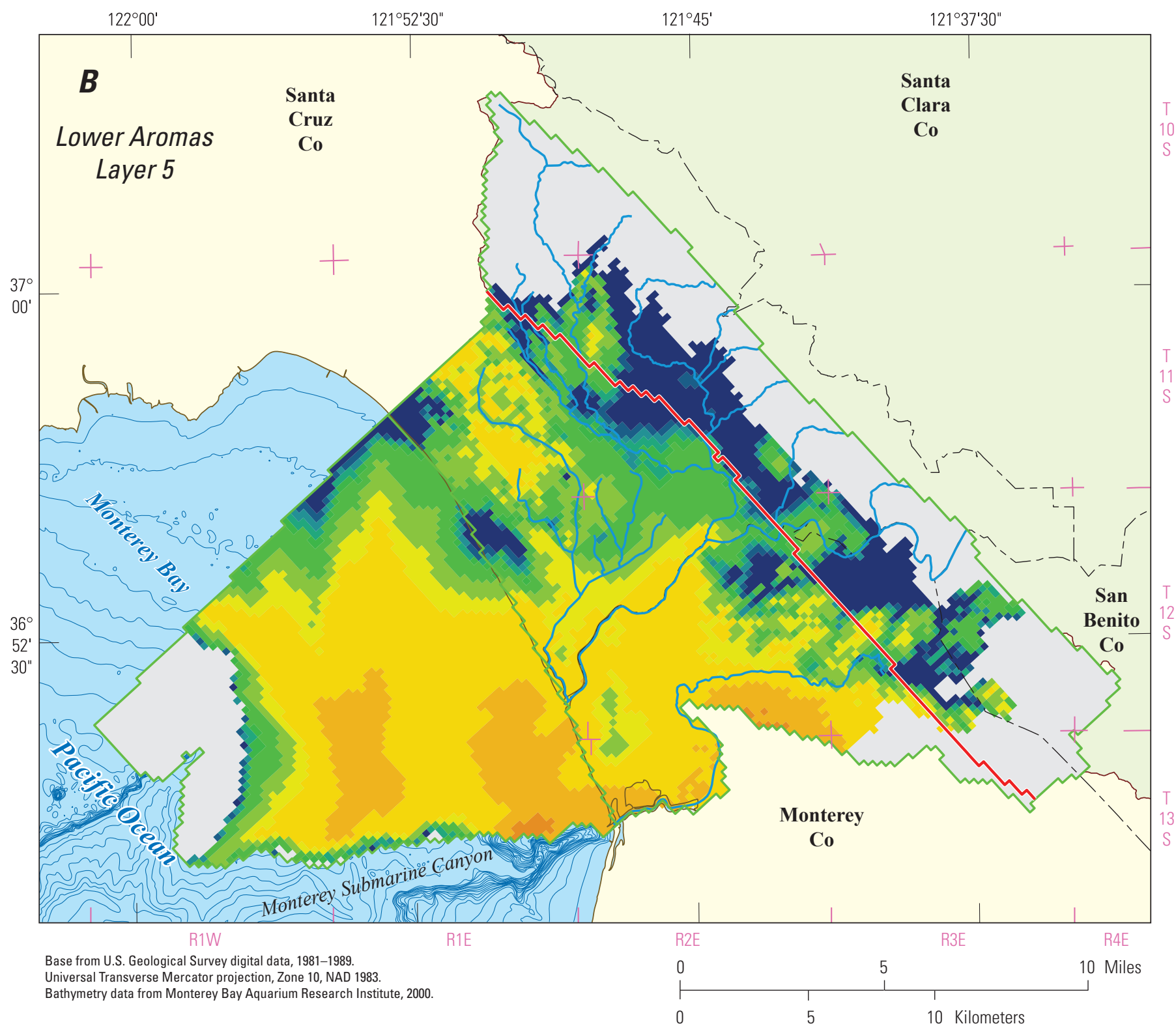

\section{EXPLANATION}

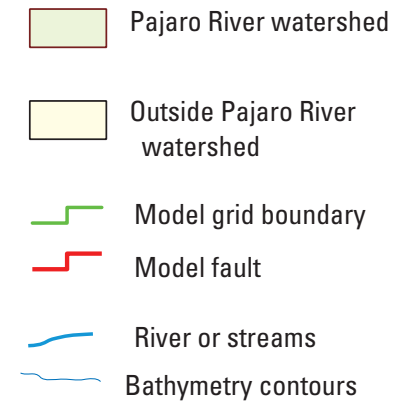

Lower Aromas thickness, in meters (feet)

Less than or equal to 5 (16.4)

Greater than 5 to 10 (16.4 to 32.8)

Greater than 10 to 15 (32.8 to 49.2 )

Greater than 15 to 20 (49.2 to 65.6 )

Greater than 20 to 25 (65.6 to 82.0)

Greater than 25 to 50 ( 82.0 to 164 )

Greater than 50 to 75 (164 to 246)

Greater than 75 to 100 (246 to 328 )

Greater than 100 to 200 (328 to 656)

Greater than 200 to 300 (656 to 984)

Greater than 300 to 319 (984 to 1,047$)$

Not present

Figure 3. - Continued 


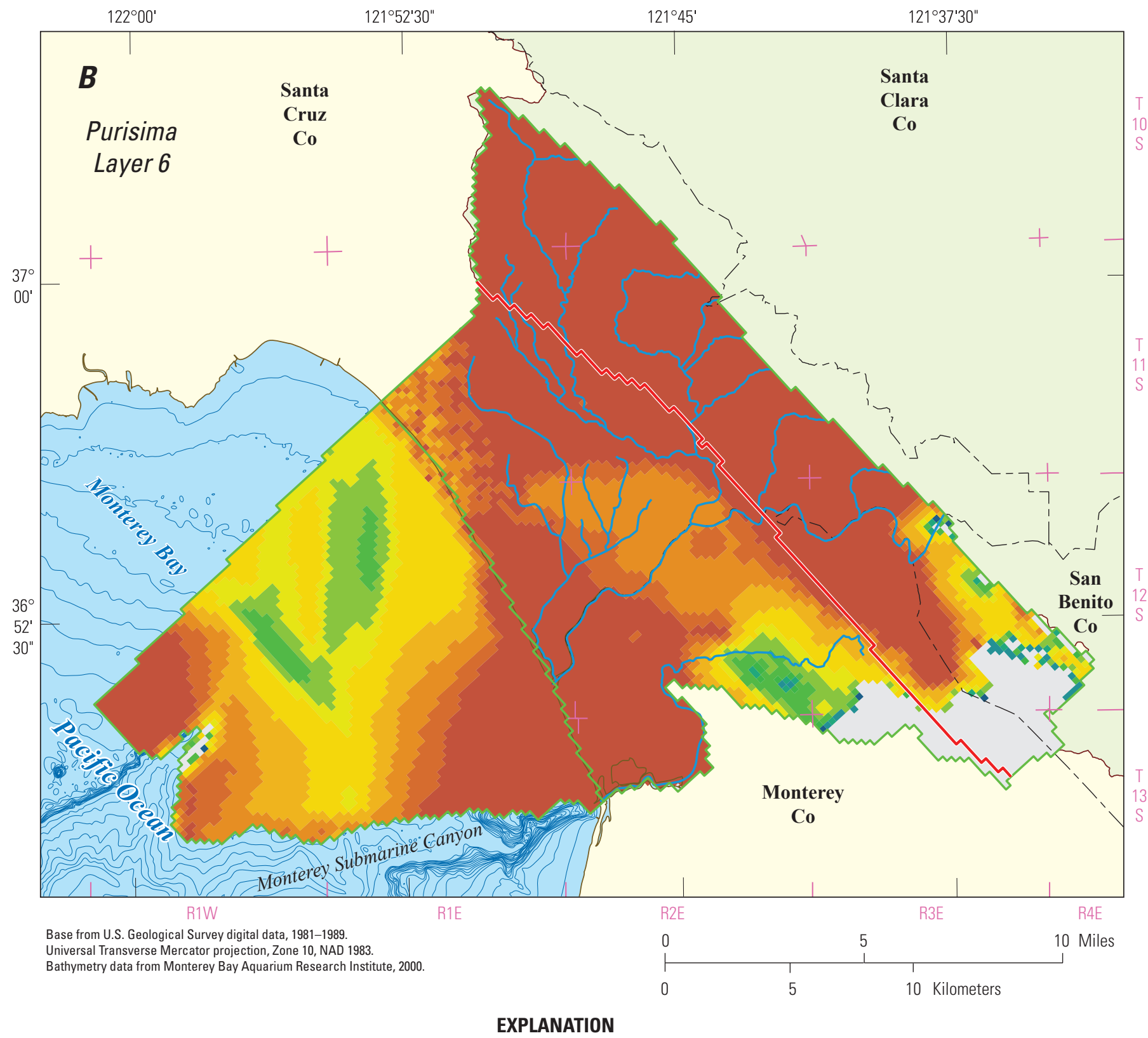

\section{$\square$ Pajaro River watershed \\ $\square$ Outside Pajaro River watershed \\ Model grid boundary \\ Model fault \\ River or streams \\ Bathymetry contours}

Purisima thickness, in meters (feet)

Less than or equal to 5 (16.4) [Not present]

Greater than 5 to 10 (16.4 to 32.8 )

Greater than 10 to 15 (32.8 to 49.2)

Greater than 15 to 20 (49.2 to 65.6)

Greater than 20 to 25 (65.6 to 82.0)

Greater than 25 to 50 (82.0 to 164)

Greater than 50 to 75 (164 to 246)
Greater than 75 to 100 (246 to 328 )

Greater than 100 to 200 (328 to 656)

Greater than 200 to 300 (656 to 984)

Greater than 300 to 400 (984 to 1,312)

Greater than 400 to $500(1,312$ to 1,640$)$

Greater than $500(1,640)$ (truncated in the model to $500 \mathrm{~m}$ )

Bedrock outcrop

Figure 3. - Continued 
C

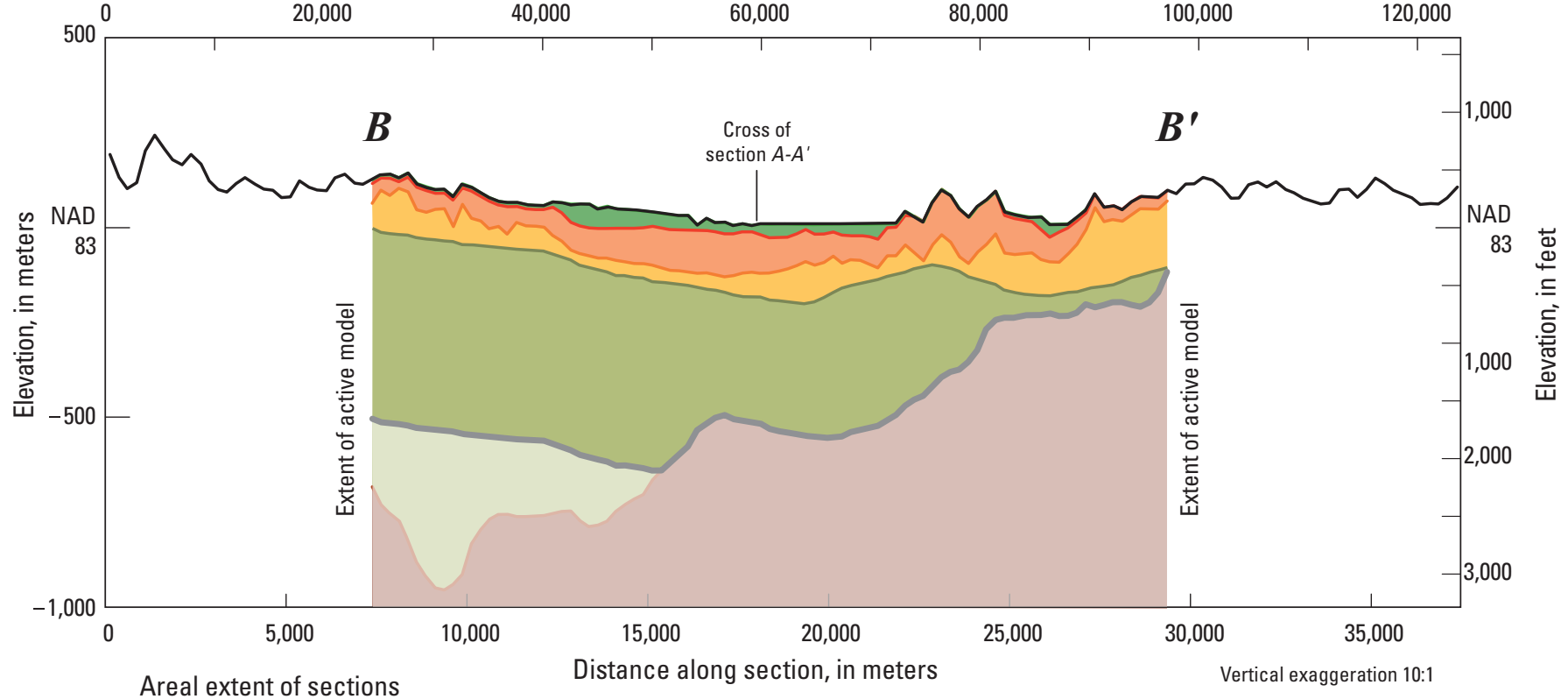
shown on figure $3 A$

EXPLANATION

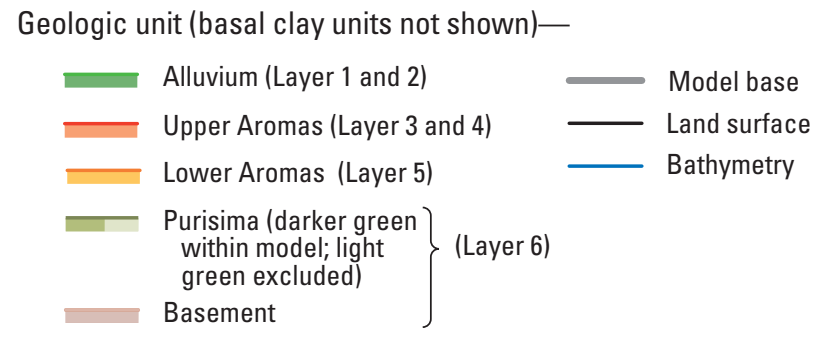

Layer structure

Alluvium

(Layer 1)

Alluvial confining unit (Layer 2)

Upper Aromas

(Layer 3)

Aromas confining unit (Layer 4)

Lower Aromas

(Layer 5)

Purisima

(Layer 6)

Figure 3. - Continued 


\section{Hydrologic System}

The conceptual model for the hydrologic cycle starts with inflows from precipitation and streamflow (fig. $2 A$ ). Streamflow enters the Pajaro Valley in the Pajaro River through the Chittenden gap and as runoff from the local stream networks. Infiltration of runoff, along with infiltration of irrigation water, contributes to groundwater recharge. Additional underflow of groundwater as inflows and outflows occurs along the coastal, northern, and southern boundaries of the valley (fig. $2 A$ ). Outflow also occurs as evapotranspiration of precipitation, surface-water, and groundwater from natural vegetation, urban landscapes, and irrigated agriculture; as groundwater pumpage for agricultural, urban, domestic, and industrial uses; and as runoff from irrigation and precipitation and from tile-drain flows. The drain flows represent the potential interception of deep percolation of excess irrigation water or precipitation moving downward from the land surface or of groundwater that has risen to high levels in the Alluvial aquifer during periods of wet conditions or reductions in pumpage. These inflows and outflows represent natural processes as well as man-made supply and demand components of water use. Since 2002, the developed hydrologic system also includes the capture, recharge and reuse of local recharge through an aquifer-storage and recovery system Since 2008, recycled urban wastewater has been used to supplant coastal agricultural pumpage.

\section{Climate}

The climate of the Monterey Bay region is temperate, with mild summers and wet, cool winters. The record of cumulative departure of precipitation (from the long-term mean value) at the CW (http://www.wrcc.dri.edu/cgi-bin/ cliMONtpre.pl?ca9473) for more than 100 years shows major and minor wet and dry periods are typical of the long-term climate for Pajaro Valley (fig. 4A). The mean precipitation for Pajaro Valley ranges from 16 in. near the coast to more than 40 in. in the foothills of the Santa Cruz Mountains.
The average precipitation for the $\mathrm{CW}$ is about $22 \mathrm{in.} \mathrm{for} \mathrm{a}$ 131-year period of record (1880-2010). The average annual precipitation for the simulation period of 1963-2010 for the model domain shows the orographic effects trending south to north, with precipitation increasing from about 18.6 in. to 55 in. (fig. 4B). The time series of annual precipitation volume indicates that most of it falls within the larger mountain-front inland regions (fig. 4C). Ten major wet and dry periods can be defined by inflections in the cumulative departure curve during the period of simulation of October 1963 through December 2009 (fig. 4A; table 2).

Time series analysis of the long-term hydrologic data in the Monterey Bay region and Pajaro Valley suggest a significant influence in climate variability derived from periodicities that are coincident with the oscillations of the El Nino-Southern Oscillation (ENSO), 2-6 years; the North American Monsoon-Pineapple Express (NAMS/PE), 7-10 years; and the Pacific Decadal Oscillation (PDO), 10-30 years (Hanson and others, 2006). When the spectral methods outlined by Hanson and others (2004) are applied, the long-term precipitation record from Watsonville shows periods of 33 and 10-18 years (PDO), 7 years (NAMS/PE), 3-6 years (ENSO), and annual periods that explain 97 percent of the total variation in precipitation. Similarly, the longterm streamflow record from the Pajaro River at Chittenden shows periods of $10-15$ years (PDO), $2-5$ years (ENSO), and annual periods, that explain 99 percent of the total variation in streamflow. Most of the variation in precipitation and streamflow occurs in the longer climate cycles. These cycles will be important periods for the evaluation of interdecadal sustainability of the water resources.

The average annual reference evapotranspiration $\left(\mathrm{ET}_{\mathrm{h}}\right)$ values show orographic effects similar to those for precipitation. From the highest $\mathrm{ET}_{\mathrm{h}}$ values of about 45.7 inches per year (in./yr) in the foothills of the Santa Cruz Mountains, $\mathrm{ET}_{\mathrm{h}}$ decreases to about $38.8 \mathrm{in}$./yr at the south end of the Pajaro Valley near Elkhorn Slough (fig. 4D). The highest $\mathrm{ET}_{\mathrm{h}}$ value consistently occurs in the inland areas of Pajaro Valley. 
$\boldsymbol{A}$

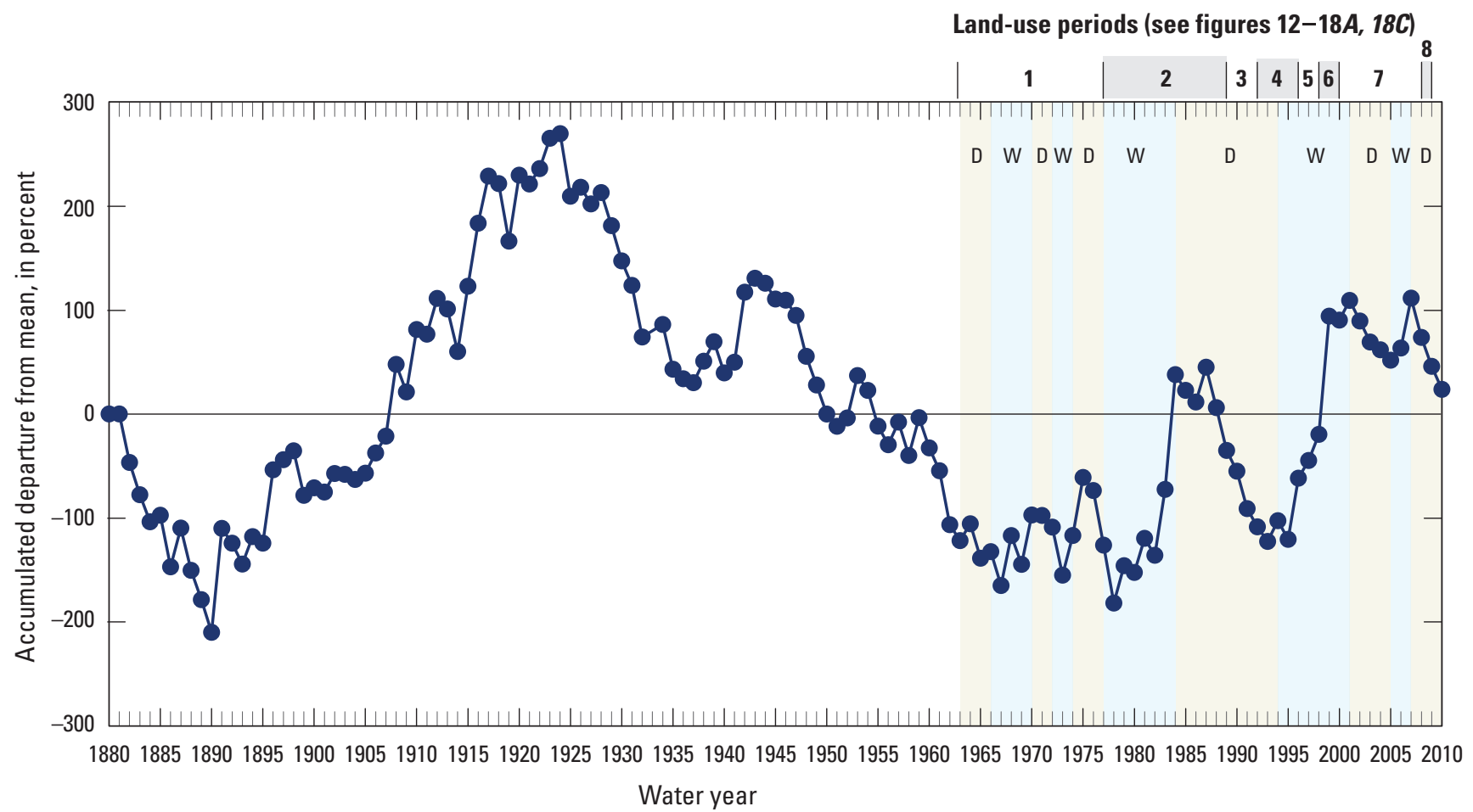

\section{EXPLANATION}

\begin{tabular}{|c|c|c|c|c|}
\hline & \multirow{2}{*}{$\begin{array}{l}\text { Cumulative departure of } \\
\text { precipitation at Watsonville, Calif. }\end{array}$} & \multicolumn{3}{|c|}{ Land-use periods- } \\
\hline & & 1 & 1970 & Figure 12 \\
\hline & Recent precipitation cycles & 2 & 1989 & Figure 13 \\
\hline $\mathrm{D}$ & (1) & 3 & 1991 & Figure 14 \\
\hline & Ury & 4 & 1993 & Figure 15 \\
\hline W & Wet & 5 & 1997 & Figure 16 \\
\hline & & 6 & 2000 & Figure 17 \\
\hline & & 7 & 2006 & Figure $18 \mathrm{~A}$ \\
\hline & & 8 & 2009 & Figure $18 \mathrm{C}$ \\
\hline
\end{tabular}

Figure 4. $\quad A$, Wet-dry periods, land-use map periods, periods of application for land-use maps, and precipitation cumulative departure; $B$, average annual precipitation; $C$, average annual precipitation for the simulation period; and $D$, average annual reference evapotranspiration for the simulation period, Pajaro Valley, California. [ASR, Aquifer-Storage-and-Recovery; CDS, Coastal Distribution System; >, greater than] 


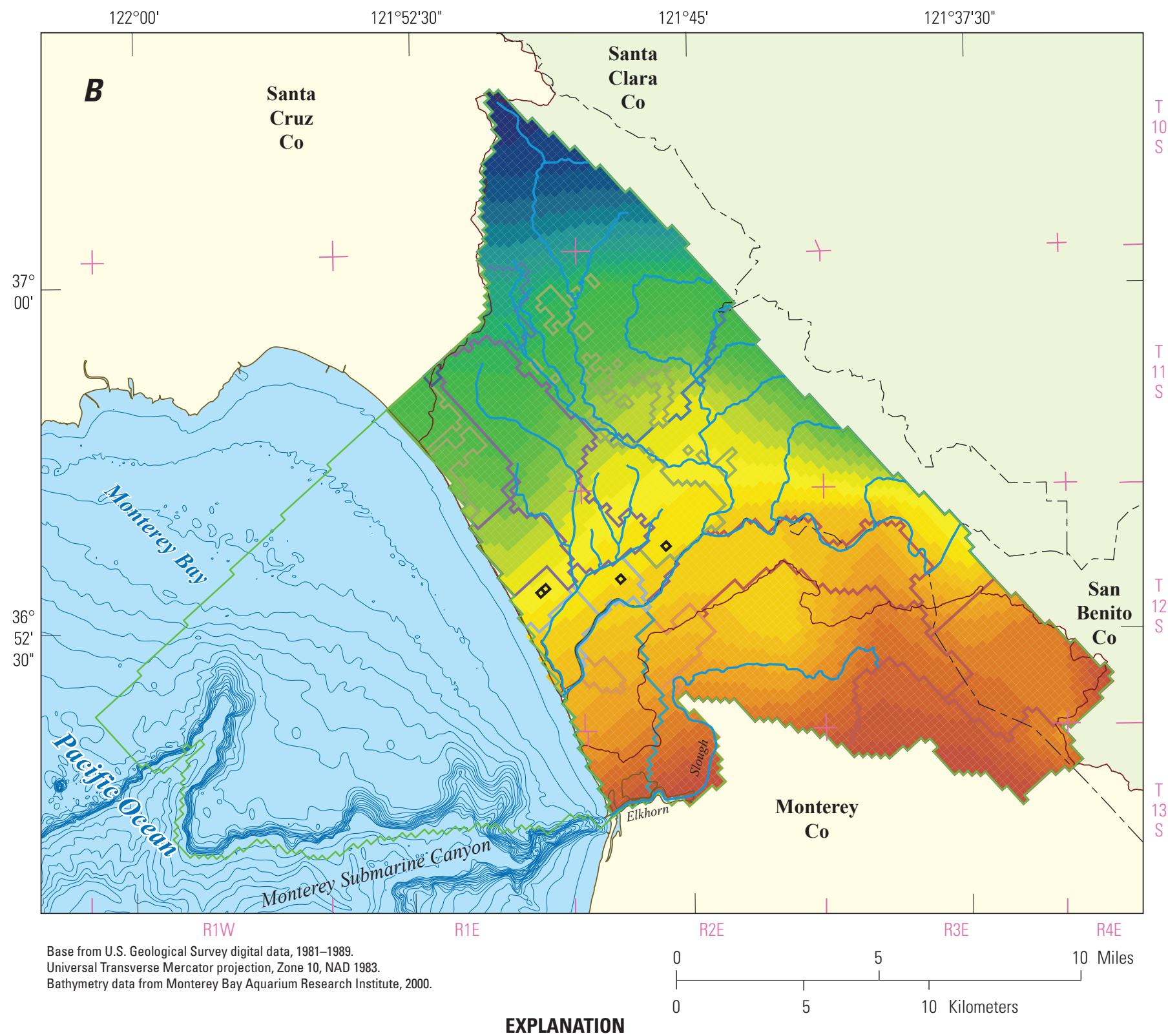

\section{EXPLANATION}

Precipitation, in inches per year

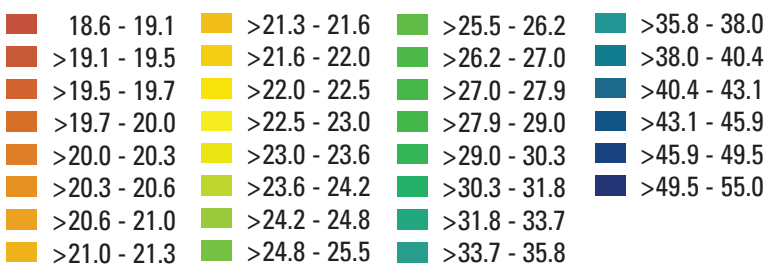

Sub-Region

$\square$ ASR system

$\square$ Santa Cruz County coast CDS

$\square$ Monterey County coast nonCDS

Monterey County coast CDS

$\square$ Santa Cruz County coast nonCDS

$\square$ Santa Cruz County water districts

Monterey County inland

Santa Cruz County inland

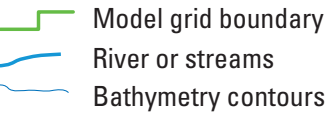

Figure 4. -Continued 


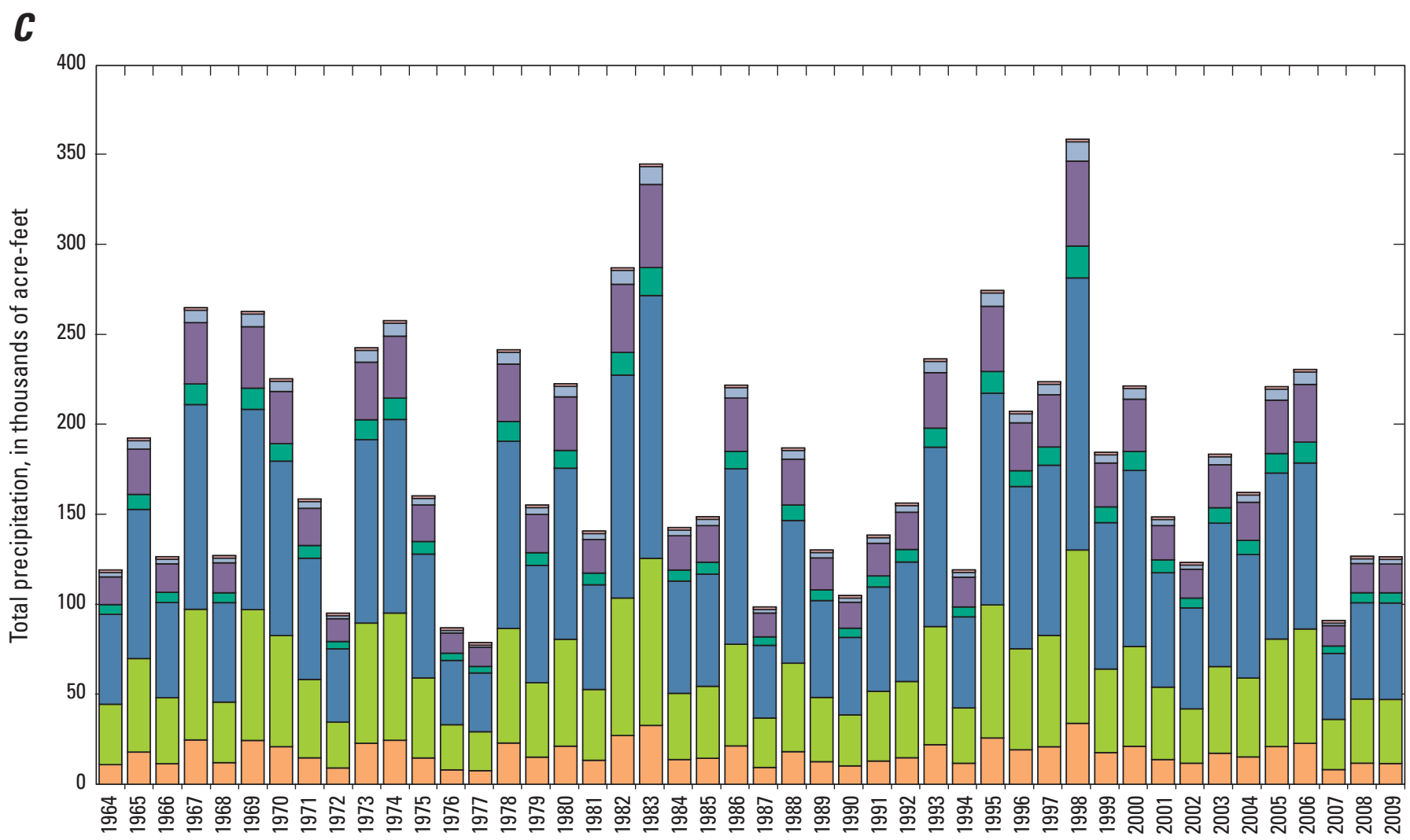

\section{Water year}

EXPLANATION

Sub-Region

$\square$ ASR system

$\square$ Santa Cruz County coast CDS

$\square$ Santa Cruz County coast nonCDS

$\square$ Monterey County coast CDS
Santa Cruz County inland

Monterey County inland

$\square$ Water purveyors

Figure 4. - Continued 


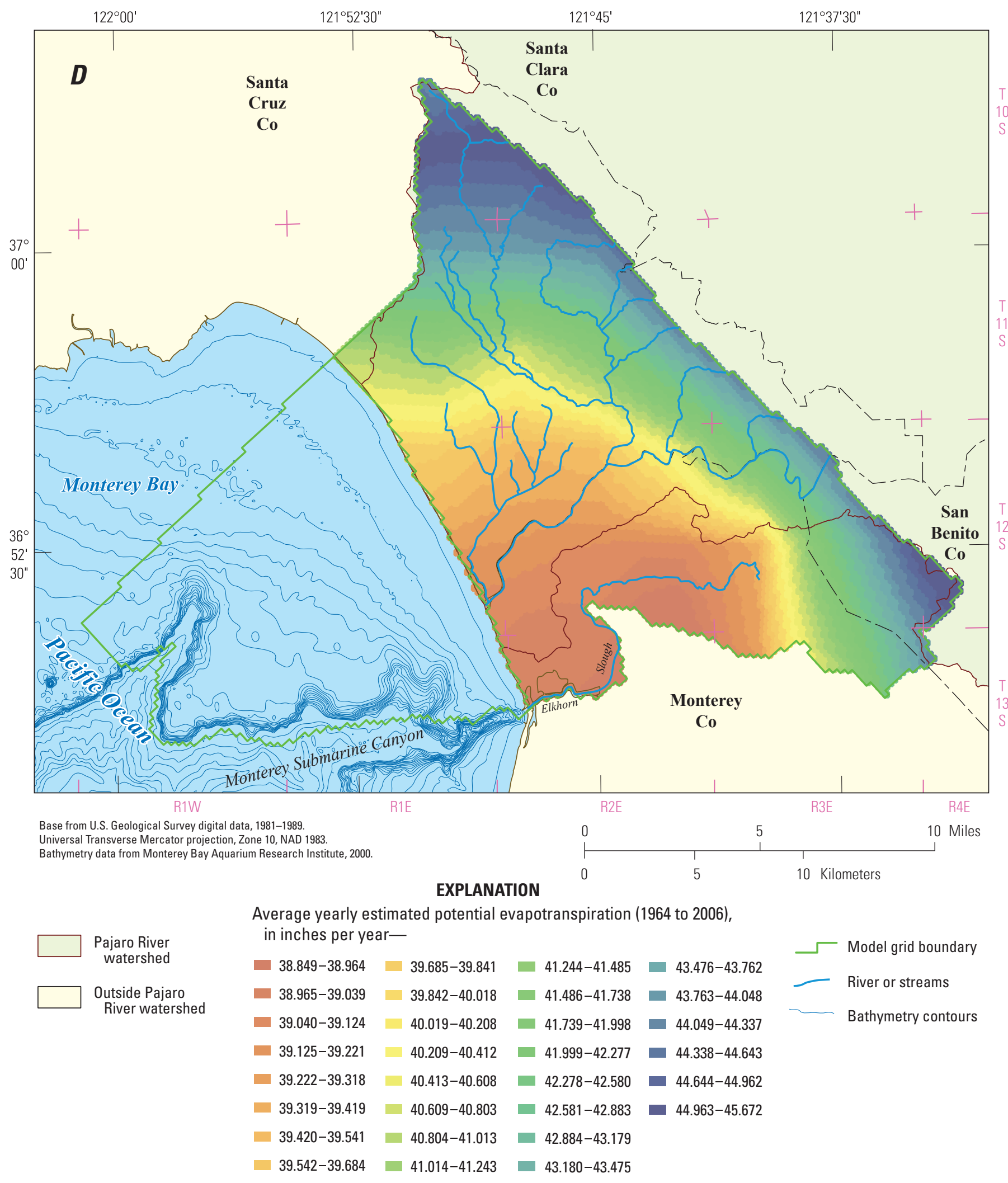

Figure 4. - Continued 
Table 2. Summary of climate periods, related model simulation, and related land-use periods for the Pajaro Valley.

\begin{tabular}{|c|c|c|c|}
\hline $\begin{array}{c}\text { Period } \\
\text { (calendar years) }\end{array}$ & $\begin{array}{l}\text { Climate } \\
\text { period }\end{array}$ & $\begin{array}{c}\text { Model stress periods } \\
\text { (months since October 1963) }\end{array}$ & $\begin{array}{l}\text { Land-use } \\
\text { map }\end{array}$ \\
\hline $1963-1966$ & DRY & $1-39$ & 1970 \\
\hline $1971-1972$ & DRY & $88-111$ & 1970 \\
\hline $1973-1974$ & WET & $112-135$ & 1970 \\
\hline $1984-1993$ & DRY & $144-351$ & 1989 \\
\hline 1994 - 2001 (1997-DRY) & WET & $352-447$ & $\begin{array}{c}1993(-96) / 1997(-98) / 2000 \\
(99-00)\end{array}$ \\
\hline $2002-2005$ & DRY & $448-495$ & 2006 \\
\hline
\end{tabular}

\section{Surface Water}

Streamflow originates as runoff outside the Pajaro Valley and enters through the Pajaro River, and runoff from within the valley moves toward small tributaries and then to the river. (fig. 1). Streamflow into the Pajaro Valley is currently measured at two gaging stations: the Pajaro River at Chittenden (11159000) and Corralitos Creek at Freedom (11159200; figs. 1, 5). A third gaging station measured the flow of Corralitos Creek at Corralitos (11159150) near Freedom further upstream (fig. 5) during the period 1958-73 and a fourth station measured downstream flow on Green Valley Creek (11159400) during water years 1964-67. The Pajaro River at Chittenden almost always contains flow, with a median discharge of about 12 cubic feet per second $\left(\mathrm{ft}^{3} / \mathrm{s} ; 8,700\right.$ acre-ft/yr; Hanson, 2003a, fig. 7). Five additional downstream gaging stations were temporarily operated by University of California at Santa Cruz (A. Fisher, University of California at Santa Cruz, written commun., 2007) just below the streamflow diversions on Brown's Creek and on the west branch of Corralitos Creek, on Corralitos Creek at Brown's Valley Road and at Varni Road, and on the Pajaro River at Murphy's Crossing (fig. 5). These additional stations were operated between 2001 and 2006 for measuring flows of less than about $150 \mathrm{ft}^{3} / \mathrm{s}$, and provide some of the more detailed streamflow loss and gain estimates for the Corralitos Creek and the upper reaches of the Pajaro River from recent years. Flow in the Pajaro River is partly regulated upstream from the Pajaro Valley by upstream releases and diversions. Similarly, the flow on Corralitos Creek is affected by the diversions on Brown's Creek and the west branch of Corralitos Creek as well as by urban and agricultural runoff.

Streamflow at the downstream stations operated by the USGS and University of California at Santa Cruz (Andrew
Fisher, University of California at Santa Cruz, written commun., 2007) and seasonal variations in streamflow show that the flow is largely related to winter runoff. Large amounts of water flowed to Monterey Bay during the short period of record even though these years were predominantly dry years. Streamflow below Murphy's Crossing (PR-10.9) totaled about 244,000 acre-ft/yr for 2002-06 with a mean monthly flow of 4,067 acre-ft $\left(68 \mathrm{ft}^{3} / \mathrm{s}\right)$ and a median of 42 acre- $\mathrm{ft}\left(0.7 \mathrm{ft}^{3} / \mathrm{s}\right)$. The streamflow exhibits losses and gains for different reaches between Chittendon and Murphy's Crossings, but indicates a total net infiltration of about 227,000 acre-ft for this same period. Ruehl and others (2006), and Hatch and others (2010) showed stream losses between Chittenden and Murphy's Crossing of 7.1 to $14.2 \mathrm{f}^{3} / \mathrm{s}\left(0.2\right.$ to $\left.0.4 \mathrm{~m}^{3} / \mathrm{s}\right)$. Streamflow below the diversions on the upper reaches of the Corralitos Creek also exhibits inflow and outflows between the diversions (Brown's Valley Bridge (BV), Varni Road Bridge (VR), and Corralitos at Freedom (CF)); streamflow below CF totaled about 54,000 acre- $\mathrm{ft}$ for the period October 1963 through December 2006, with a median monthly flow of 0.11 acre-ft $\left(0.002 \mathrm{ft}^{3} / \mathrm{s}\right)$. In downstream order below the diversion, the streamflow gains and losses were estimated to be a loss of about 6,300 acre-ft (October 2002-July 2006) between the diversions and $\mathrm{BV}$, a gain of about 5,300 acre-ft between $\mathrm{BV}$ and VR (October 2002-September 2006), and a gain of about 7,900 acre-ft (October 2002-December 2006) between VR and CF. While many upstream reaches show streamflow losses for some months, some reaches also show gains that are the result of additional overland flow. The reaches on the Pajaro River (segments 37, 40, 43, and 44, fig. 5), between highway 129 and Murphy's Crossing and on Corralitos Creek between the diversions and $\mathrm{BV}$, are predominantly losing reaches, whereas the lower reaches of the Corralitos Creek above Freedom generally gain flow. 


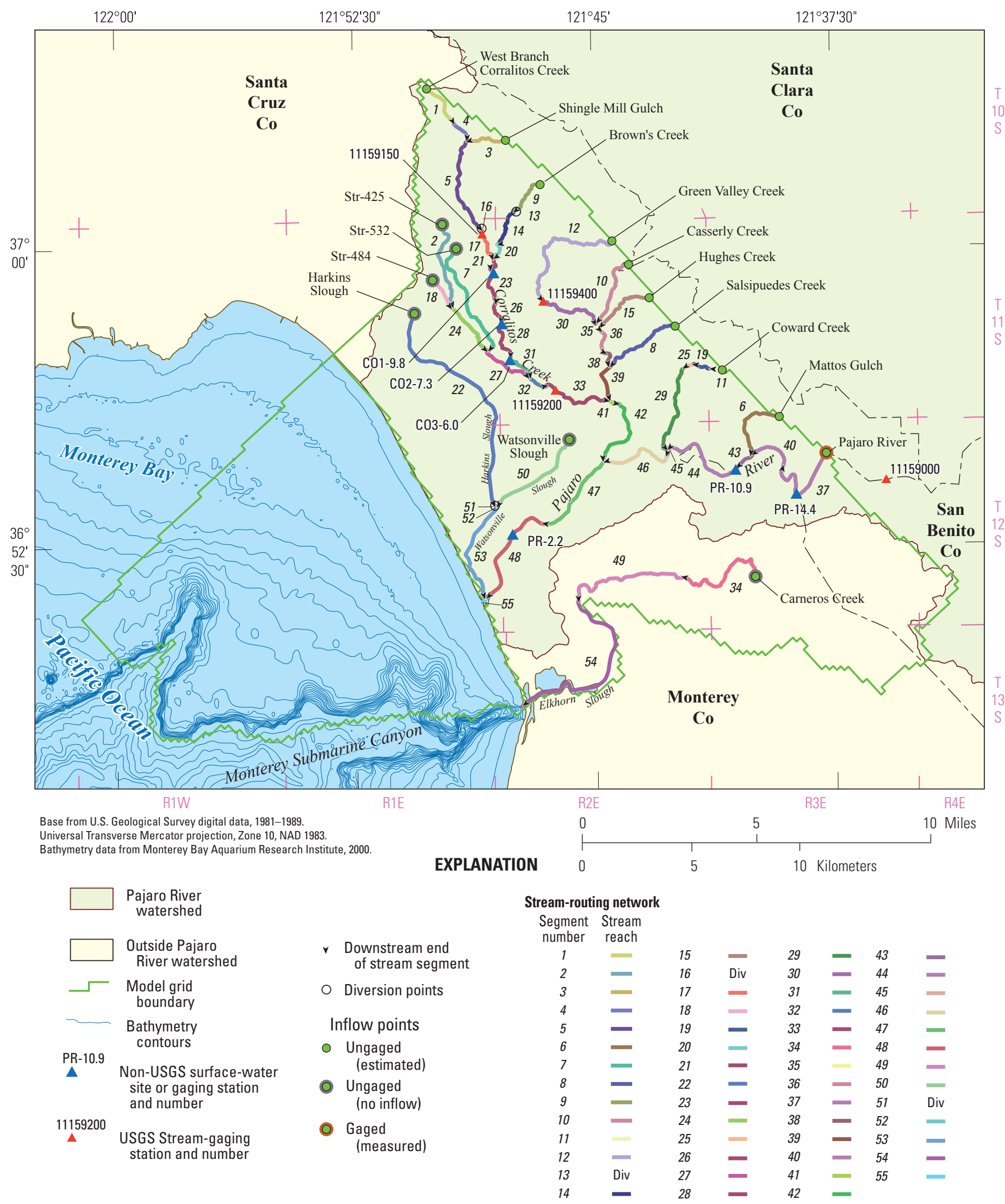

Figure 5. The stream network with streamflow routing cells and segments, streamgaging stations and other measurement sites, and location of inflows and diversions, Pajaro Valley, California. 
Changes in the natural streamflow that have occurred with the development of the surface-water system include the construction of diversions for drinking-water supply and more recently for agricultural supply and artificial recharge (fig. 5). Diversions occur in the upper watershed of Corralitos Creek on Brown's Creek and the west branch of Corralitos Creek. These upstream diversions provide supplemental water supply for the CW and represent about 46,900 acre-ft between October, 1963 and December, 2009. A diversion from Harkins Slough supplied about 5,120 acre-ft of water to the ASR system operation between 2002 and 2009. The CDS delivered about 2,730 acre- $\mathrm{ft}$ of the water diverted from Harkins Slough, or about 53 percent of the total water diverted and delivered to the ASR system. Thus, some local recharge is occurring from water not directly recaptured by the ASR system operation (Hanson and others, 2008).

\section{Groundwater}

Under predevelopment conditions in the Pajaro Valley, groundwater flowed from the foothills of the Santa Cruz Mountains to the Pacific Ocean. Under developed conditions, decades of withdrawals in excess of recharge has altered the movement of groundwater to onshore flow of seawater and the formation of regional cones of depression in the center of the valley. These persistent depressions show superimposed seasonal declines in groundwater levels that are driven by higher agricultural and municipal pumpage during summer. Groundwater inflows include recharge from infiltration of precipitation, streamflow, and applied water from irrigation (fig. 2A). In addition, underflow occurs along the northern and southern boundaries of the model and from the offshore portions of the aquifer systems. Along with deep percolation of precipitation, streamflow infiltration is the other major source of natural recharge in Pajaro Valley. Groundwater outflow includes pumpage from wells (fig $6 A$ ) and tile drains (fig. $6 B$ ), base flow or rejected recharge along streams, evapotranspiration, and subsurface underflow to the offshore portions of the aquifer systems and discharge to the ocean along submarine outcrops on the ocean shelf, Monterey submarine canyon, and Elkhorn Slough (fig. 2A).

Development of groundwater resources has resulted in the construction and pumping from more than 2,700 wells (fig. 6A). These include more than 1,695 domestic wells, 32 municipal-supply wells, and as many as 1,026 irrigation wells by 2009 (fig. 6A). Total pumpage for water supply grew from about 6,000 acre-ft in water year 1964 to more than 12,000 acre-ft in water years 1987-88, and then leveled off to about 11,000 acre-ft in 2006-09 with variations for wet and dry periods (fig. 7). The domestic pumpage was estimated on the basis of population and an assumed consumption of 0.6 acre-ft per year per land parcel for each domestic well identified by PVWMA. A minor amount of the increase can also be attributed to the increase in rural residential (domestic) pumpage between 1964 and 1997 while contributions from Soquel Creek Water District (SCWD) and the $\mathrm{CW}$ have remained relatively consistent since the drought of the mid-1980s and early 1990s (fig. 7). The majority (58 percent) of water supply is pumped by the $\mathrm{CW}$, with SCWD pumping 16 percent, municipal water companies pumping about 8 percent, and rural residential usage pumping an additional 18 percent. For the period 1999-2009, the overall distribution of pumpage is 79 percent agricultural supply, 18 percent municipal water supply, and 3 percent domestic use. Agricultural pumpage can vary by as much as 18 percent between sequential wet and dry years during this period and is similar to the 20 percent variation reported for other coastal agricultural basins (Hanson and others, 2009). 


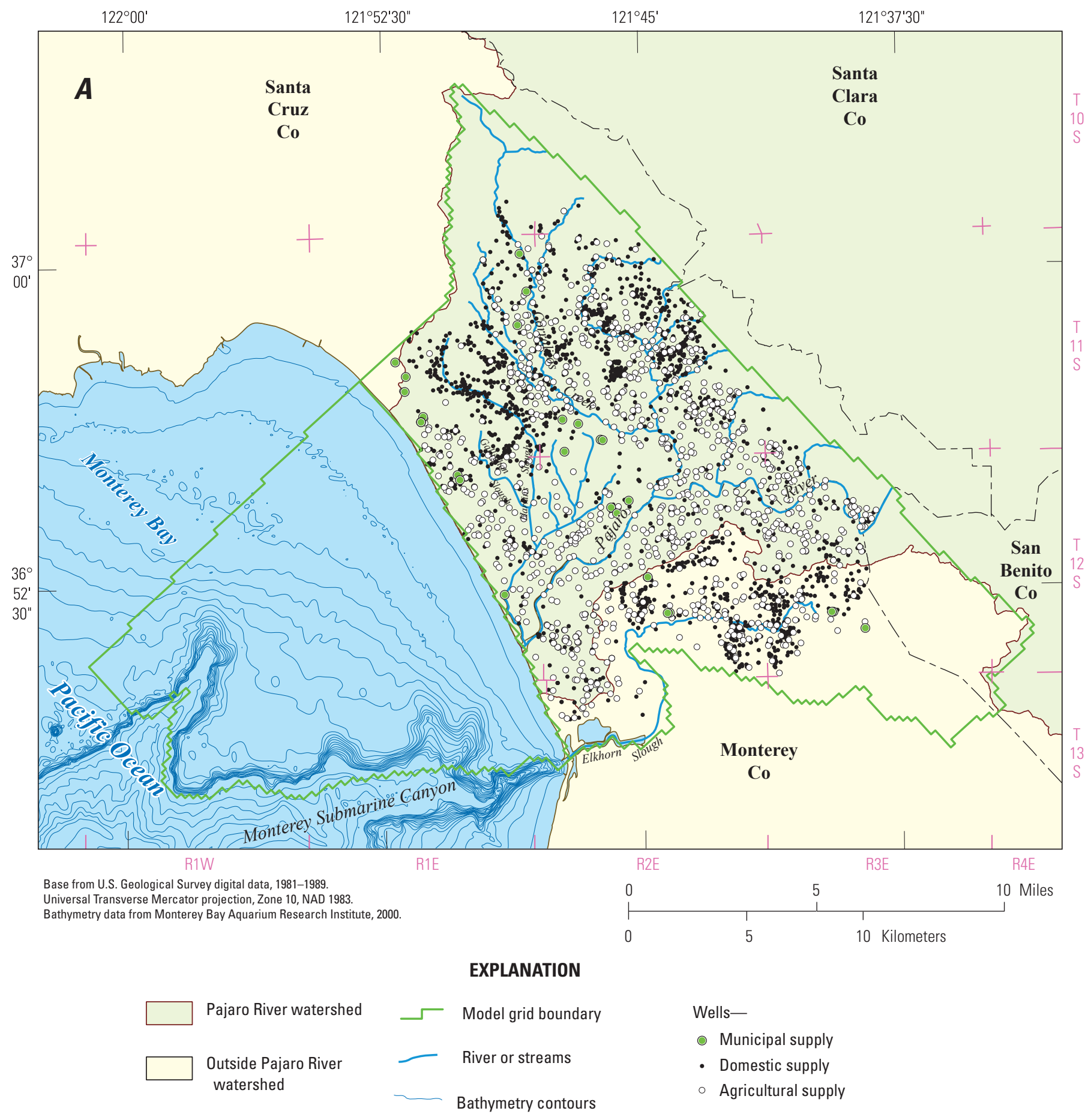

Figure 6. A, Distribution of agricultural, urban-supply, and domestic wells (indicate single and multi-aquifer wells); and $B$, modeled tile drain areas, Pajaro Valley, California. 


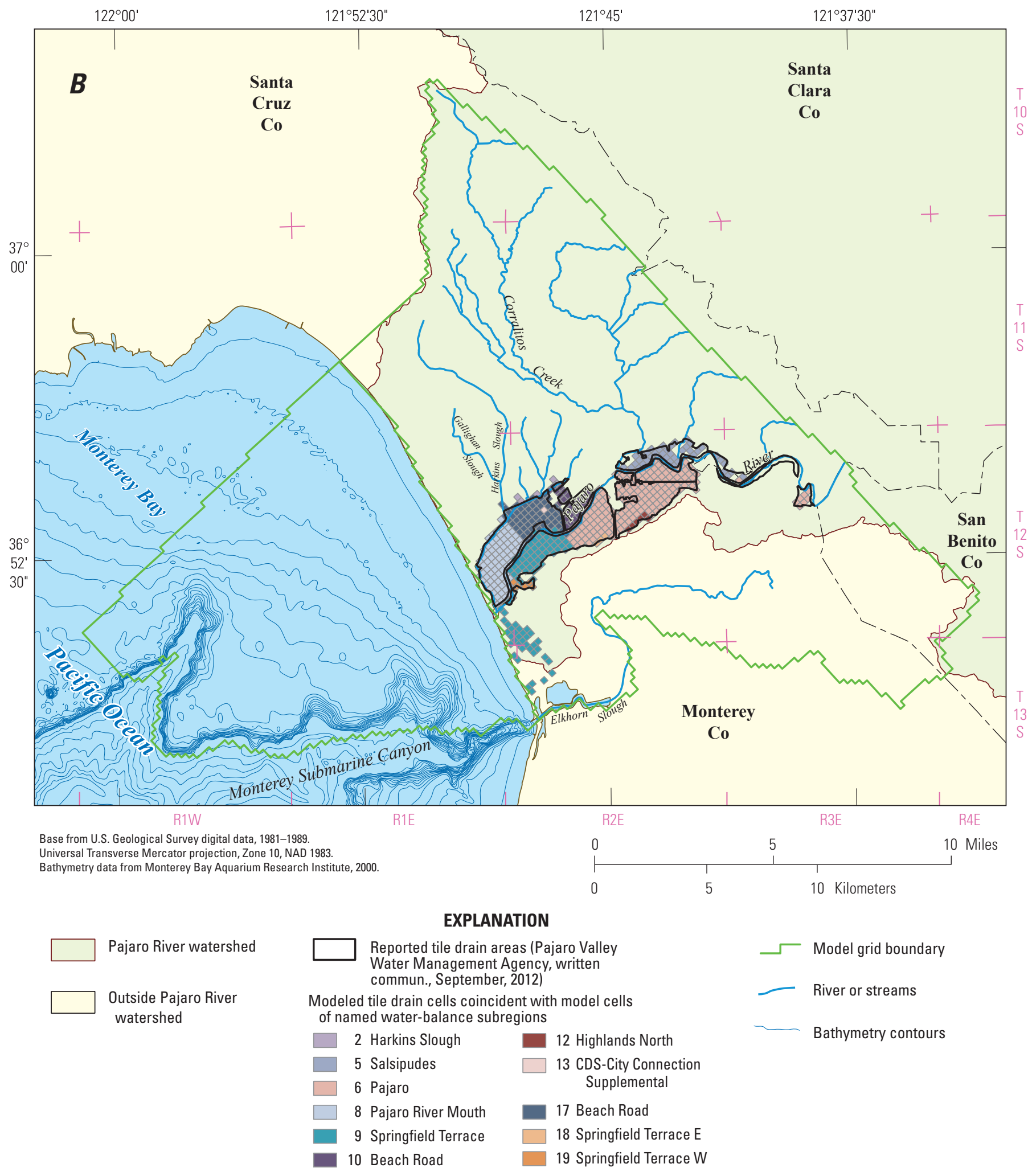

Figure 6. - Continued 


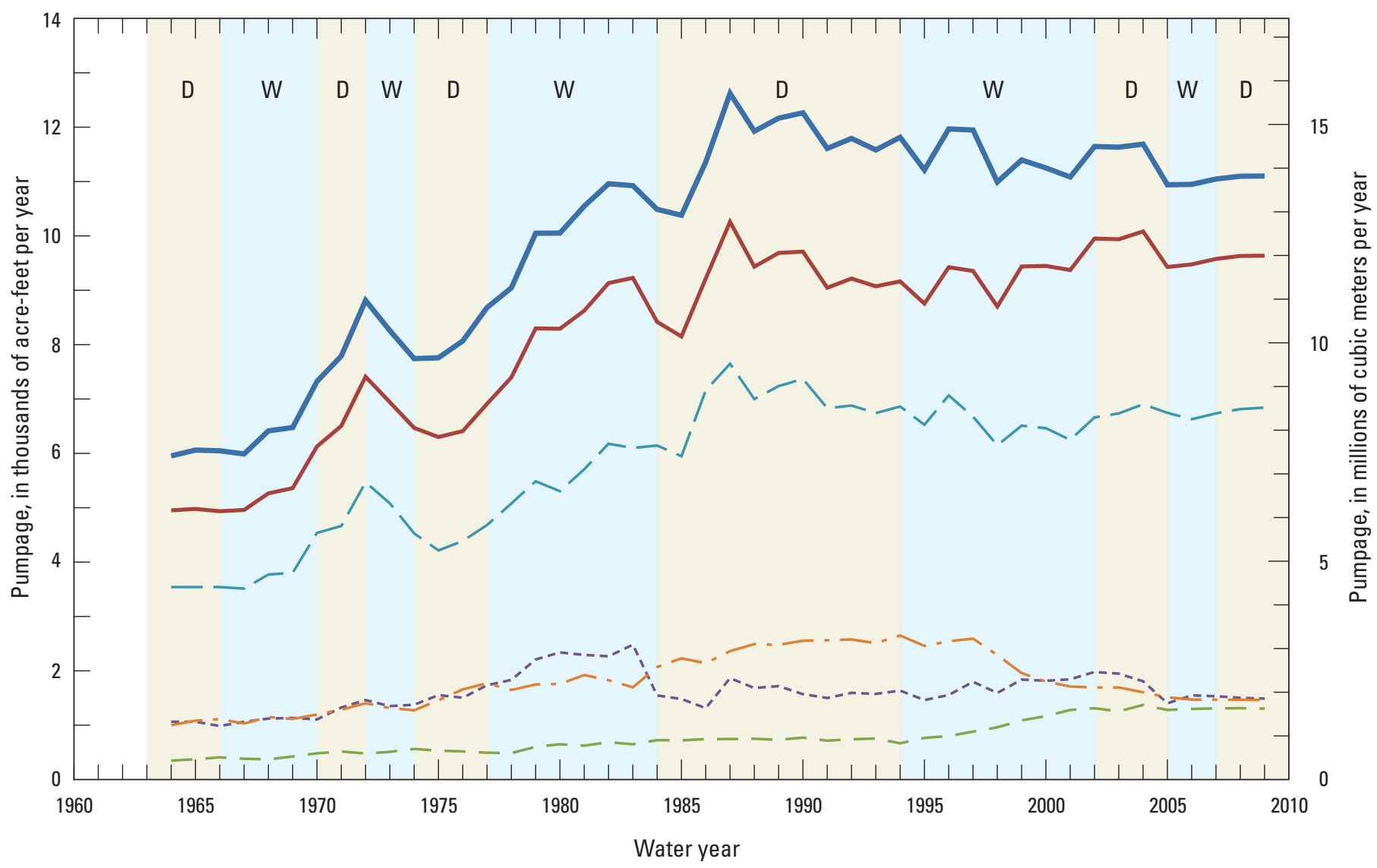

\section{EXPLANATION}

PumpageRecent precipitation cycles

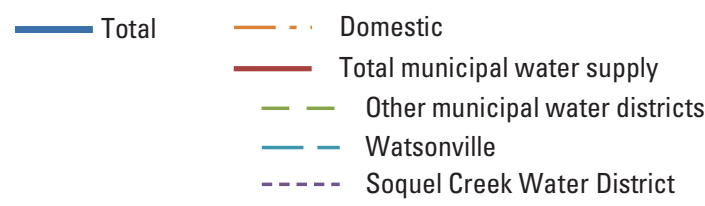

Dry

Wet

Figure 7. Estimated groundwater pumpage from municipal and domestic wells, Pajaro Valley, California.

\section{Previous Regional Groundwater Models}

Because of the long history of groundwater development and its impacts, many hydrologic investigations have been done in the Pajaro Valley. The California Department of Water Resources (CADWR), the USGS, and various local and federal agencies have completed such studies. Many of these studies were summarized by Hanson (2003a, b) and by Lear (2001). The earliest systematic studies included characterizations of the geohydrologic framework and some investigators calculated hydrologic budgets prior to the development and common use of numerical flow models (California State Water Resources Board, 1953; Muir, 1972, 1974, 1977; Muir and Johnson, 1979; Johnson, 1983; J.H. Kleinfelder and Associates, 1983). Since those early studies, a number of site-specific and regional groundwater models have been developed by various federal and local agencies. Two regional groundwater flow models and one subregional transport model are described briefly below.

\section{Initial Pajaro Valley MODFLOW Model}

The first groundwater model of Pajaro Valley was a three-layer USGS flow model (Johnson and others, 1988) that simulated a total loss from storage of about 23,000 acre- $\mathrm{ft}$ between spring 1970 and the fall of 1981. The average storage loss of about 2,100 acre-ft/yr, combined with the average simulated seawater intrusion of about 1,700 acre-ft/yr, yielded an average rate of overdraft of about 3,800 acre-ft/yr for the period 1970-81. The model showed rapid losses in storage of about 43,000 acre-ft that mostly occurred during the 1976-77 
drought period. This loss was followed by a storage recovery of 20,000 acre- $\mathrm{ft}$ in the subsequent wet period of 1978-80. The simulated pumpage for the upper layer (alluvium) was concentrated in the Corralitos subarea and in the northern parts of Salsipuedes, Harkins Slough, and San Andreas subareas. For the middle aquifer (Upper Aromas), simulated pumpage was distributed throughout the landward part of the model area. Municipal pumpage was about 7 percent of total simulated pumpage. The deepest simulated pumpage from the lower-aquifer system (Lower Aromas) occurred in the Beach Road, Pajaro River Mouth, and Watsonville subareas, and in the southern part of San Andreas subarea (Johnson and others, 1988, fig. 15). The estimated annual pumpage was about 92 percent of the outflow and started at 40,900 acre-ft in 1963, growing to 61,700 in 1971 and $71,000 \mathrm{acre}-\mathrm{ft} / \mathrm{yr}$ in 1981 . The fraction of precipitation that became recharge ranged from 5 to 30 percent, was about 78 percent of the inflow, and was simulated to be about $51,500 \mathrm{acre}-\mathrm{ft} / \mathrm{yr}$. Recharge from streamflow infiltration averaged about 12,000 acre-ft/yr. Groundwater recharge from irrigation return flow was estimated to range from 20 to 30 percent of applied water.

\section{Subregional Transport Model}

A one-layer flow and transport model of the middle aquifer system (Bond, 1986; Bond and Bredehoeft, 1987) simulated changes in pumpage, flow, and storage comparable to those in the model by Johnson and others (1988).

Pumpage varied seasonally and ranged from as low as $10,150 \mathrm{acre}-\mathrm{ft} / \mathrm{yr}$ in winter to as high as $42,750 \mathrm{acre}-\mathrm{ft} / \mathrm{yr}$ for the summer season during the drought of 1977 (Bond, 1986; Bond and Bredehoeft, 1987). Summer seasonal pumpage was simulated to vary by as much as 13,050 acre-ft/yr for the period 1970-81. The proportions of flow simulated by this model indicate that about 60 percent of the recharge to the middle aquifer comes from leakage: 17 percent from the lower aquifers, 40 percent from the upper-aquifer system, 36 percent from terrestrial underflow, 5 percent from submarine outcrop inflow, and 2 percent from ocean-floor leakage. The relative proportion of all outflows, except for changes in groundwater storage, was 85 percent to pumpage, 6 percent to the loweraquifer system, 4 percent to ocean-floor leakage, 3 percent to the upper-aquifer system, and about 2 percent each to the landward and submarine outcrop boundaries. Results of the simulation of chloride transport by this model indicated that the sloughs and estuaries contribute the least chloride to the middle-aquifer system; leakage through the ocean floor provided the largest source of chloride. The simulated inflow of chloride as seawater from submarine outcrops was a minor proportion of total chloride inflow until the mid-1980's, when it became comparable to ocean-floor leakage in contributing chloride to the middle-aquifer system (Bond, 1986; Bond and Bredehoeft, 1987); however, that inflow was largely restricted to the area around Springfield Terrace (fig. 2B).

\section{Initial Pajaro Valley IGSM Model}

The first integrated groundwater-surface water model of Pajaro Valley (PVIGSM) was a four-layer IGSM finiteelement model (Montgomery Watson, 1993a) initially developed to simulate hydrologic conditions over a 29-year period (1964-92) for the entire landward PVWMA region (Montgomery, 1990; Montgomery Watson, 1993b). This simulation indicated that more than 75 percent of the streamflow infiltration and about 67 percent of all recharge occurred in the two subregions of Salsipuedes-Murphy Crossings and Corralitos (fig. 2B, regions 1 and 5). About half of the pumpage occurred in those two subregions-33 percent in Salsipuedes-Murphy Crossings and 18 percent in the Corralitos. Coastal pumpage represents about 22 percent of the total pumpage, with about 9 percent from each of the two subregions of San Andreas and Springfield. The estimated pumpage steadily increased over time, and the 1992 pumpage was about 18 percent greater than the 29 -year average.

Superimposed on this increase were changes in pumpage of as much as 10,000 acre-ft/yr in the inland subareas that appear to be coincident with climatic periods. Three regional pumping troughs were delineated from previous studies (Montgomery, 1990, fig. 7B) in the Watsonville area (Corralitos, SalsipuedesMurphy Crossings, and the Watsonville subareas) and in the coastal areas of Pajaro River Mouth, Springfield, and the southern part of San Andreas subregion (fig. $2 B$, regions 8+10, $9+18+19+20$, and $16+14+13+21$, respectively).

The cumulative removal of water from storage was simulated to be about 169,000 acre-ft, yielding an average rate of about 5,800 acre-ft/yr. More than 80 percent of this loss was simulated to occur in the eastern-inland subregions (fig. $2 B$ ). The cumulative change in storage through time for each of the 10 previously delineated subregions indicated that the largest declines in storage occur in the foothill subregions of Carneros Hills (28 percent), Carneros Creek (19 percent), and Salsipuedes-Murphy Crossing (26 percent). The loss of water from storage in the Carneros Hills (region 11) and Carneros Creek (region 12) subregions was driven, in part, by pumping in the nearby Salsipuedes-Murphy Crossing subregion.

The cumulative overdraft includes removal of water from groundwater storage and an additional 113,000 acre- $\mathrm{ft}$ of seawater intrusion. About 43 percent of the overdraft occurred in the coastal regions and about 50 percent occurred in the inland regions (fig. 2B). The total overdraft for this period was simulated as about 282,000 acre-ft, yielding a rate of about 9,700 acre-ft/yr. About half of this overdraft occurred during the dry periods of 1976-79 and 1988-91. The simulated basin-wide loss of water from storage accounted for 60 percent of overdraft. Most of the simulated overdraft comes from about half of the subregions and represents coastal seawater intrusion and inland water from groundwater storage. The rates of seawater intrusion and overdraft for the initial model were reported to average about 5,400 acre-ft/yr and 11,200 acre-ft/yr respectively (Montgomery Watson, 1993b). 


\section{Revised Pajaro Valley IGSM Model}

The revised PVIGSM model included updates to the historical simulation through the year 1997, extension of the finite-element mesh offshore, and adjustments in model parameters (Teghavi and Smith, 1999a-d). The mesh was extended offshore to the submarine outcrops (fig. 3A), to the north to include the southern subregions of the SoquelAptos area, and to the south to include additional parts of northern Monterey County. The landward extensions helped to facilitate the coupling of the PVIGSM with models of SoquelAptos area and Salinas Valley. The adjustments in hydraulic properties included a significant reduction in the vertical hydraulic conductivity between model layers in the northern subregions of Corralitos, Harkins Slough, and San Andreas.

The revised PVIGSM simulation indicated that more than 79 percent of the streamflow infiltration and about 59 percent of all recharge occurred in the two subareas of Salsipuedes and Corralitos. About half (55 percent) of the pumpage still occurred in the Salsipuedes-Murphy Crossings subarea (41 percent) and the Corralitos subarea (14 percent). Coastal pumpage represented about 25 percent of the total pumpage, with about 10 and 11 percent from each of the two subareas of San Andreas and Springfield, respectively. The Watsonville and Beach Road subareas each had about 4 percent of total pumpage. The estimated pumpage steadily increased (Hanson and others, 2003a, fig. 4), and the 1997 pumpage was about 21 percent greater than the 34-year average. Superimposed on this increase are changes in pumpage of as much as $10,000 \mathrm{acre}-\mathrm{ft} / \mathrm{yr}$ in the inland subareas; these changes appear to be coincident with climatic periods (fig. 4A). Two regional pumping troughs were delineated from the revised simulation (Teghavi and Smith, 1999d, figs. 13-16) in the Watsonville area (Salsipuedes, Pajaro River, Beach Road, and the Watsonville subareas) and in the coastal areas of Pajaro River Mouth, Springfield and, the southern part of San Andreas subareas. The most extensive and largest declines in water levels were simulated to occur during the 1987-92 drought in the lower Aromas Sand as demonstrated by the large regions with simulated water levels more than $20 \mathrm{ft}$ below sea level in 1990 (Teghavi and Smith, 1999d, fig. 15C).

The revised PVIGSM model simulations indicated cumulative removal of water from storage of about 354,000 acre-ft over the 34-year period, yielding an average rate of about 10,400 acre-ft/yr. More than 57 percent of this loss was simulated to occur in the eastern-inland subareas and an additional 11 percent offshore in the Monterey Bay subregion (fig. 2A, region 25). The cumulative change in storage through time for each of the 13 subareas indicated that the largest declines in storage occurred in the inland subregions of Pajaro River (region 6; 21 percent) and
Salsipuedes (12 percent), and additional losses in the Highlands South (region 11; 4 percent) and Highlands North (region 12; 8 percent) subregions. The loss of water from storage in the Highlands subregions was substantially less than other nearby inland subregions but may still be driven by the pumpage trough in the adjacent Salsipuedes and Pajaro River subareas. The second largest loss of storage of 32 percent occurred in the coastal subregions of San Andreas (5 percent), Pajaro River Mouth (10 percent), Beach Road ( 5 percent), and Springfield (12 percent).

The cumulative overdraft simulated by the revised PVIGSM model included removal of water from groundwater onshore storage of 233,000 acre-ft and an additional 222,000 acre-ft of offshore storage depletion from coastal inflow (seawater intrusion) that represents 101,000 acre-ft of submarine leakage and 121,000 acre-ft of offshore storage depletion. The total simulated overdraft for this 34-year period of about 455,000 acre-ft yields a rate of about $13,400 \mathrm{acre}-\mathrm{ft} / \mathrm{yr}$. About half of this overdraft occurred during the dry periods of 1976-79 and 1987-91. About half of the simulated storage depletion occurred in the inland subregions. Most of the simulated overdraft occurred in about half of the subareas. The historical rates of seawater intrusion for the revised PVIGSM model were reported to average about 6,500 acre-ft/yr.

The revised PVIGSM model simulation results show a mean inflow in the upper aquifer system and mean outflow in the lower aquifer system (Purisima Formation) in the San Andreas subregion and reduced storage depletion. The Pajaro mouth and Springfield subregions are simulated to have coastal inflow and seawater intrusion throughout all model layers (Teghavi and Smith, 1999f, fig. 17B). Most of the seawater intrusion is simulated to occur in the Alluvial and Aromas Sand aquifers, with a total rate of intrusion that varies climatically between 4,000 and 10,000 acre-ft/yr (Teghavi and Smith, 1999f, fig. 18A). The largest proportion of intrusion was simulated in the upper and lower Aromas Sand (Teghavi and Smith, 1999f, fig. 18B). Most of the simulated recharge is from deep percolation of precipitation and applied irrigation water with boundary inflows a minor component (Teghavi and Smith, 1999f, fig. 11). The deep percolation of precipitation, amount of water applied for irrigation, and boundary inflows vary with climate conditions, therefore recharge, storage depletion, and intrusion can be considered to be climatically driven. The average water budget indicated by the revised PVIGSM included 69,000 acre-ft/yr of pumpage, 39,000 acre-ft/yr of recharge from precipitation and applied water, 3,000 acre-ft/yr of boundary flows, 17,000 acre-ft/yr of streamflow infiltration, and no outflow to the bay, which collectively yields 10,000 acre-ft/yr of overdraft (Raines, Melton, and Carella, Inc., 1999, fig. 3-2). 


\section{PVHM Model Development}

The PVHM was developed on the basis of historical conditions for the analysis of the use and movement of water throughout the valley and to provide a basis for addressing the effects of the new BMP components that will be developed as part of the updated sustainability analysis. In order to maintain the usefulness of a numerical hydrologic flow model, periodic updates will be required as the hydrologic system continues to respond to the changing stresses imposed upon it and as new information on the surface-water and groundwater systems becomes available. The PVHM was developed using the finitedifference hydrologic modeling software MODFLOW-2005 (MF2K5; Harbaugh, 2005; Harbaugh and others, 2000; Hill and others, 2000) and incorporates an updated version of the Farm Process (FMP2; Schmid and Hanson, 2009), which permits more-detailed and realistic simulation of agricultural and other processes on the landscape. MF2K5 with the Farm Process (MF-FMP2) is an integrated hydrologic model that incorporates a dynamically coupled water supply-and-demand accounting within agricultural areas and areas of native vegetation. Thus, the MF-FMP2 code provides the simulation of conjunctive use with linkages of supply-constrained and demand-driven use and movement of water across the landscape, surface-water, and groundwater flow systems (fig. 8; Hanson and others, 2008, 2010).

The PVHM was constructed in phases. The first phase was the conversion of the model from the previous revised PVIGSM model (Teghavi and Smith, 1999f). In the second phase, the converted model was further modified to include the inflows and outflows of the updated conceptual model and the new model layering and distribution of hydraulic properties. In the third phase, the model was updated and calibrated through 2006 with the inclusion of the ASR system and CDS components of the developed hydrologic system, and then recalibrated and updated through 2009. Table 3 summarizes the components of MF-FMP2 (processes and packages) used for the PVHM.

The hydrologic model (PVHM) was adjusted during model development, but calibrated primarily after the two final phases, with the aid of trial-and-error and automated parameter estimation calibration. The parameter estimation code (UCODE-2005; Poeter and others, 2005) was used to calculate model sensitivities and parameter estimates.
The model was calibrated to heads, head differences, head changes with time, streamflow, streamflow losses and gains, diversions, and pumpage estimates. During construction and calibration of the model, it became evident that several updates and enhancements were needed within MF2K5, the FMP2, and some post-processing software. These updates and enhancements are summarized in the documentation of FMP2 (Schmid and Hanson, 2009).

The PVHM model components can be grouped in terms of the discretization, initial conditions, boundaries, streamflow, groundwater pumpage, land-use, aquifer characteristics, and water budgets. The development of these model components is described in the following sections.

\section{Discretization}

The PVHM boundary encompasses the alluvial deposits of the entire Pajaro Valley, extending from the Santa Cruz Mountains on the east to the submarine shelf and outcrops beneath the Pacific Ocean to the west and bounded on the north by the Corralitos Creek watershed and on the south by the Granite Ridge (fig. 2A). The finite-difference model grid used to represent the land surface and subsurface alluvial deposits consists of a series of orthogonal square model cells. Spatial and temporal discretization are held to uniform increments throughout space and time.

\section{Spatial Discretization and Layering}

The total active modeled area is $543 \mathrm{mi}^{2}$ on a finitedifference grid consisting of 150 rows, 150 columns, and 6 layers (figs. 1B, 3C). About 43 percent of the cells are active with 65 percent $\left(150 \mathrm{mi}^{2}\right)$ of these active cells in the landward part of the hydrologic model. The model has a uniform horizontal discretization of 15.4 acres per cell $(820.2 \mathrm{ft}$ by $820.2 \mathrm{ft}$, equal to $250 \mathrm{~m}$ by $250 \mathrm{~m}$ ) and is oriented subparallel to the shoreline, 42.4 degrees west of due north (fig. $1 B$ ). This cell size was chosen to be comparable to the typical land parcel size and to facilitate the future linkage of the PVHM model with remotely sensed land-use data for potential updates of land use and other landscape properties. The bounding coordinates for the total model grid are summarized in table 4. 


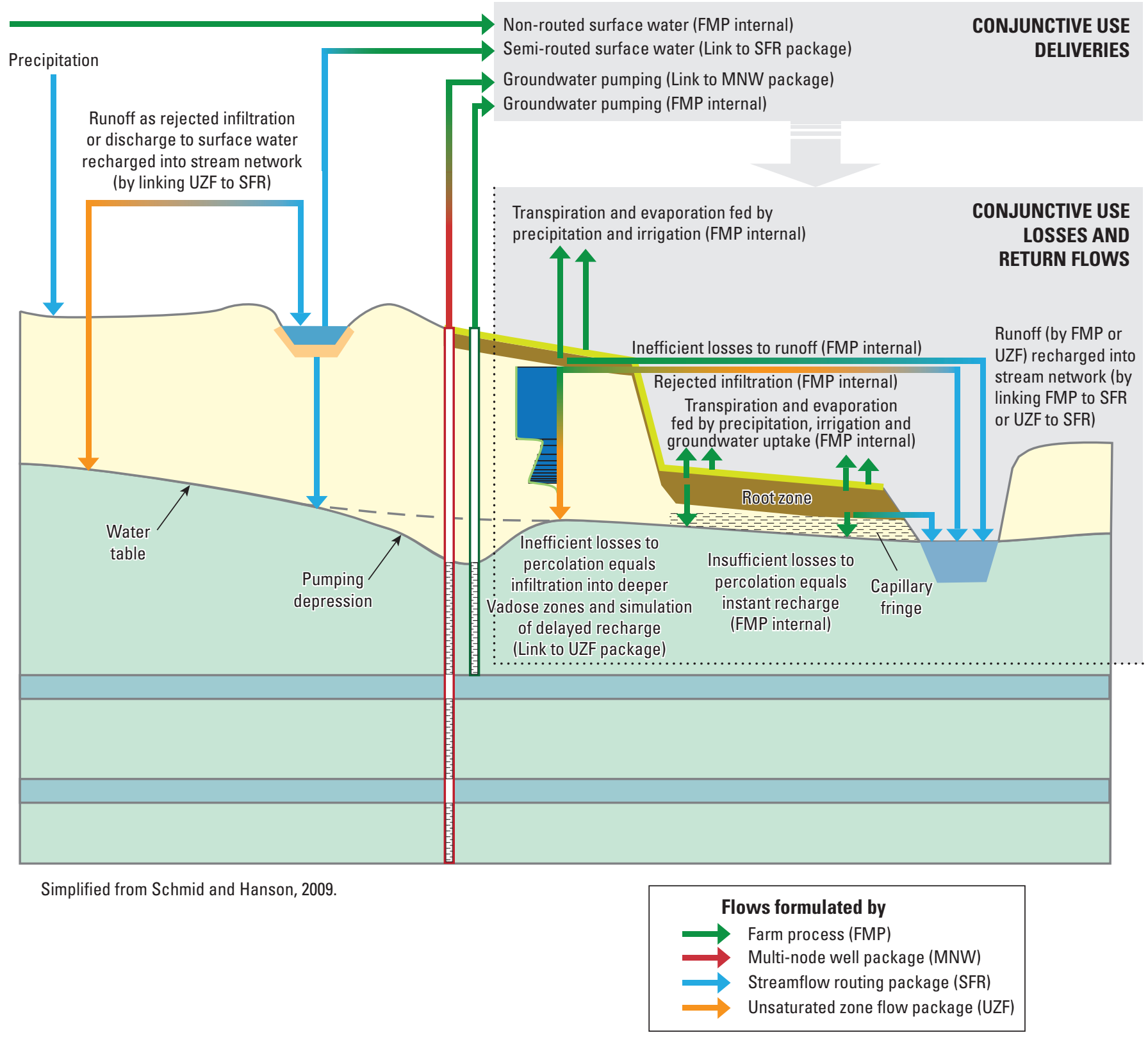

Figure 8. The flow interdependencies within MODFLOW-FMP2 between the landscape, streamflow, and groundwater flow components required to simulate a coupled hydrologic flow system (Schmid and Hanson, 2009).

The six model layers are aligned with the hydrostratigraphic units described previously. The top of the hydrologic model is represented by the elevation of the land surface or ocean floor and is a composite of model layers 1 , 3 , and 6 (fig. 3A). The uppermost Alluvial aquifer model layer (layer 1) ranges in thickness from an assumed minimum of $16 \mathrm{ft}(5 \mathrm{~m})$ to an estimated maximum of about $381 \mathrm{ft}(116 \mathrm{~m}$; fig. $3 B$ ). The second layer is coincident with the predominantly fine-grained basal confining layer at the base of the Alluvial aquifer system and ranges in thickness from an assumed minimum of $16 \mathrm{ft}(5 \mathrm{~m})$ to an estimated maximum of about $53 \mathrm{ft}(16 \mathrm{~m}$; fig. $3 B)$. The third layer is coincident with the extent of the upper Aromas and ranges in thickness from an assumed minimum of $16 \mathrm{ft}(5 \mathrm{~m})$ to an estimated maximum of about $502 \mathrm{ft}$ ( $153 \mathrm{~m}$; fig. 3B). The fourth layer is coincident with the basal fine-grained confining layer of the upper Aromas and ranges in thickness from an assumed minimum of $16 \mathrm{ft}(5 \mathrm{~m})$ to an estimated maximum of about $115 \mathrm{ft}$ (35 m; fig. 3B). The fifth layer is coincident with the extent of the lower Aromas and ranges in thickness from an assumed minimum of $16 \mathrm{ft}(5 \mathrm{~m})$ to an estimated maximum of about $1,047 \mathrm{ft}(319 \mathrm{~m}$; fig. $3 B$ ). The sixth layer is the lowest part of the model and is coincident with the Purisima Formation and other bedrock formations, with an assumed minimum of $16 \mathrm{ft}$ $(5 \mathrm{~m})$ to an estimated maximum of about 1,640 ft (500 m; fig. $3 B)$. 
Table 3. Summary of MODFLOW-2005 with Farm Process (MF-FMP2) packages and processes used with the hydrologic flow model of Pajaro Valley, California.

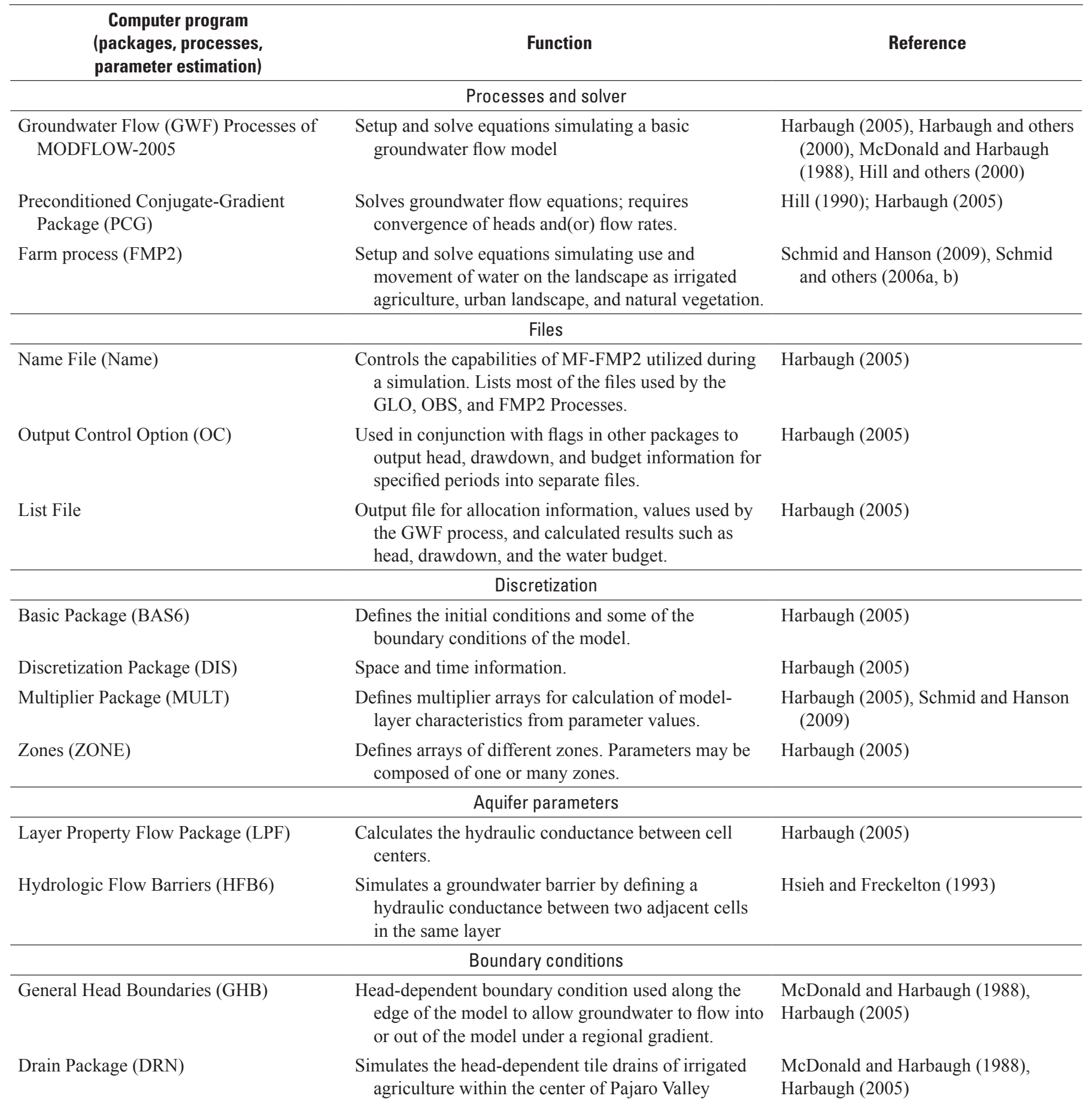


Table 3. Summary of MODFLOW-2005 with Farm Process (MF-FMP2) packages and processes used with the hydrologic flow model of Pajaro Valley, California.-Continued

\begin{tabular}{|c|c|c|}
\hline $\begin{array}{l}\text { Computer program } \\
\text { (packages, processes, } \\
\text { parameter estimation) }\end{array}$ & Function & Reference \\
\hline \multicolumn{3}{|c|}{ Recharge and discharge } \\
\hline Multi-node Wells (MNW1) & $\begin{array}{l}\text { Simulates pumpage from wells with screens that span } \\
\text { multiple layers. }\end{array}$ & Halford and Hanson (2002) \\
\hline Streamflow Routing (SFR2) & $\begin{array}{l}\text { Simulates the routed streamflow, infiltration, } \\
\text { exfiltration, runoff, and returnflows from FMP2 }\end{array}$ & Niswonger and Prudic (2006) \\
\hline \multicolumn{3}{|c|}{ Output, observations and sensitivity } \\
\hline Head Observation (HOB) & $\begin{array}{l}\text { Defines the head observation and weight by layer(s), } \\
\text { row, column, and time and generates simulated } \\
\text { values for comparison with observed values. }\end{array}$ & $\begin{array}{l}\text { Hill and others }(2000) \\
\text { Harbaugh }(2005)\end{array}$ \\
\hline Hydmod (HYD) & $\begin{array}{l}\text { Generates simulated values for specified locations } \\
\text { at each time-step for groundwater levels and } \\
\text { streamflow attributes. }\end{array}$ & Hanson and Leake (1998) \\
\hline
\end{tabular}

Table 4. Coordinates of the hydrologic flow model of Pajaro Valley, California.

[Model grid is rotated 42.4 degrees west; coordinates below are calculated at the cell center of the model grid using the North American Datum of 1983 in the Universal Transverse Mercator (UTM) Projection of North America, Zone 10; each model cell is 250 meters by 250 meters. DMS, degrees minutes seconds]

\begin{tabular}{|c|c|c|c|c|c|c|}
\hline $\begin{array}{c}\text { Corner } \\
\text { of } \\
\text { model grid }\end{array}$ & $\begin{array}{l}\text { Model } \\
\text { coordinates X } \\
\text { (column) }\end{array}$ & $\begin{array}{c}\text { Model } \\
\text { coordinates Y } \\
\text { (row) }\end{array}$ & $\begin{array}{l}\text { Latitude } \\
\text { (DMS) }\end{array}$ & $\begin{array}{l}\text { Longitude } \\
\text { (DMS) }\end{array}$ & $\begin{array}{l}\text { UTM coordinates } \mathrm{X} \\
\text { (easting) } \\
\text { (meters) }\end{array}$ & $\begin{array}{c}\text { UTM coordinates } Y \\
\text { (northing) } \\
\text { (meters) }\end{array}$ \\
\hline Northwest & 1 & 1 & $36^{\circ} 53^{\prime} 09^{\prime \prime}$ & $122^{\circ} 06^{\prime} 26^{\prime \prime}$ & $-597,547$ & $4,082,565$ \\
\hline Northeast & 150 & 1 & $37^{\circ} 06^{\prime} 39^{\prime \prime}$ & $121^{\circ} 47^{\prime} 34^{\prime \prime}$ & $-607,253$ & $4,107,844$ \\
\hline Southwest & 1 & 150 & $36^{\circ} 38^{\prime} 01^{\prime \prime}$ & $121^{\circ} 49^{\prime} 39^{\prime \prime}$ & $-604,821$ & $4,054,862$ \\
\hline Southeast & 150 & 150 & $36^{\circ} 51^{\prime} 28^{\prime \prime}$ & $121^{\circ} 30^{\prime} 48^{\prime \prime}$ & $-632,525$ & $4,080,137$ \\
\hline
\end{tabular}

\section{Temporal Discretization}

In order to represent the growing season adequately and the dynamics of changing precipitation and streamflow that collectively drive the major supply and demand components, the annual hydrologic cycle of the PVHM is discretized into monthly stress periods and biweekly time steps. Periods of user-specified model inflows and outflows and boundary heads are referred to as stress periods. Variations in stresses are simulated by changing inflows and outflows and boundary heads from one stress period to the next. These inflows, outflows, and boundary heads that include pumping, precipitation, $\mathrm{ET}_{\mathrm{h}}$, stream inflows, diversions, deliveries, sea level, and landward boundary heads are assumed to be constant within each stress period. Stress periods are further divided into time steps, which are units of time for which water levels and flows are calculated throughout all model cells. The total simulation period was 43.25 years (or 519 monthly stress periods) from October 1963 through December 2006.

\section{Initial Conditions}

Initial conditions in the model are the distribution of water levels at every active cell within each of the six model layers. The initial water levels for October 1963 were approximated by starting with water levels from the previous PVIGSM model and replacing these initial values during calibration with simulated water levels from the end of the first year (October, 1964). In this study, all model layers were simulated as confined to facilitate model calibration with parameter estimation. For confined model layers, the saturated thickness is equal to the layer thickness and does not change during the simulation regardless of the simulated value of hydraulic head. Although these layers are treated as confined, parts of model layers 1, 3, and 6 may be unconfined (California State Water Resources Board, 1953). Storage properties in the outcrop subregions (fig. $3 A$ ) of the uppermost layers $(1,3$, and 6$)$ are adjusted as necessary to represent the unconfined portion of the system (see "Storage Properties" section). 


\section{Groundwater Inflows and Outflows}

Boundary conditions are applied at some model cells to simulate the inflows and outflows from the active model region, including stream inflows, diversions, and groundwater underflow (fig. 2C). Three general types of boundary conditions are used in the model: no-flow, head-dependent, and specified flows.

\section{No-Flow Boundaries}

No-flow boundaries were used for the bottom of the model and selected landward lateral boundaries. The lower boundary was limited to the bottom of the Purisima Formation or a total thickness of Purisima and bedrock of $500 \mathrm{~m}(1,640 \mathrm{ft})$, which extends well below the deepest supply wells (fig. 3C). Lateral no-flow boundaries represent the contact between the Basement (low-permeability) rocks of the foothills and the unconsolidated alluvial sediments of Pajaro Valley in the southeastern part of the model and along the eastern side of the model, which is coincident with the San Andreas Fault Zone that traverses the foothills of the headlands of the Santa Cruz Mountains (fig. 3A).

\section{Head-Dependent Boundaries}

Two types of head dependent boundaries are used in PVHM. Subsurface and offshore flows are simulated with general-head boundaries, and drains are used to simulate tile drains where they are used for selected irrigated agriculture (fig. 6B).

\section{Groundwater Underflow Boundaries}

Groundwater underflow occurs as inflows and outflows from the landward northern and southern boundaries of PVHM and from the outcrops and lateral boundaries offshore. These are lateral and vertical hydrologic boundaries of the groundwater flow system that are simulated as a headdependent flow using general-head boundaries (fig. 9A). These regions were simulated with the General Head Boundary Package (GHB) of MODFLOW (McDonald and Harbaugh, 1988; Harbaugh and others, 2000; Harbaugh, 2005). Generalhead boundaries were specified in layers $1,3,5$, and 6 (fig. 9A) with time-varying boundary heads and cell specific conductance. The time-varying boundary heads were specified for landward subregions of the general-head boundaries on the basis of water levels from selected wells (fig. $9 B$ ) that were adjacent to the model area (table 5). These landward boundary heads varied with time from 1963-2006 and were held at the 2006 monthly levels for the updated period 2007-09. The changes in boundary heads for the offshore boundaries represent the median monthly changes in sea level from nearby San Francisco Bay (Theberge, 2010; National
Table 5. Wells from which water levels were used for timevarying Boundary Heads of General-Head Boundaries.

[CWD, Central Water District; MCWRA, Monterey County Water Resource Agency; SCWD, Soquel Creek Water District]

\begin{tabular}{llcl}
\hline \multicolumn{1}{c}{ Well } & \multicolumn{1}{c}{$\begin{array}{c}\text { Boundary } \\
\text { region }\end{array}$} & $\begin{array}{c}\text { Model } \\
\text { layers }\end{array}$ & Source \\
\hline Country Club (CC_51) & NW coastal & 3 & SCWD \\
SC-A1B & NW coastal & 5 & SCWD \\
SC-A1A & NW coastal & 6 & SCWD \\
MW-A & NW coastal & 1 & CWD \\
CWD-10 & NW coastal-inland & 3,5 & CWD \\
CWD-3 & NW inland & 3,5 & CWD \\
CWD-12 & NW coastal-inland & 6 & CWD \\
CWD_Black & NW inland & 6 & CWD \\
13S02E16D01 & SE coastal & $3,5,6$ & MCWRA \\
12S02E33H01 & SE coastal-inland & 3,5 & MCWRA \\
13S02E12D01 & SE coastal-inland & $3,5,6$ & MCWRA \\
13S03E04L01 & SE inland & 3,5 & MCWRA \\
12S03E33H01 & SE inland & $3,5,6$ & MCWRA \\
\hline
\end{tabular}

Oceanographic and Atmospheric Administrations, 2012; fig. $9 B$ ) as an equivalent fresh-water head for each offshore boundary cell for the entire simulation period. The hydraulic conductance of the lateral offshore boundary cells were based on the texture-derived hydraulic conductivity of the aquifer sediments (described in the section "Aquifer Characteristics"). Hydraulic conductances were adjusted during model calibration.

\section{Tile-Drain Boundaries}

The tile drains of the irrigated agriculture were simulated with the drain package in MODFLOW. The tile drains had a specified drain elevation that is about six $\mathrm{ft}$ below the land surface of 510 model cells that are generally coincident with the regions identified as having tile drains. The regions of tile drains were delineated by PVWMA and included cells within these regions that were not coincident with streamflow cells with nonzero streambed conductivity. Additional drain cells were added to represent the shallow sloughs in the Springfield Terrace coastal area and adjacent to Harkins Slough (fig. 6B). A total of 11 water balance regions along the central and coastal parts of Pajaro Valley adjacent to the Pajaro River floodplain contain tile drain model cells . These drains simulate the capture by tile drains or lowlands of rising groundwater and the deep percolation of excess water from irrigation or precipitation in these regions. 


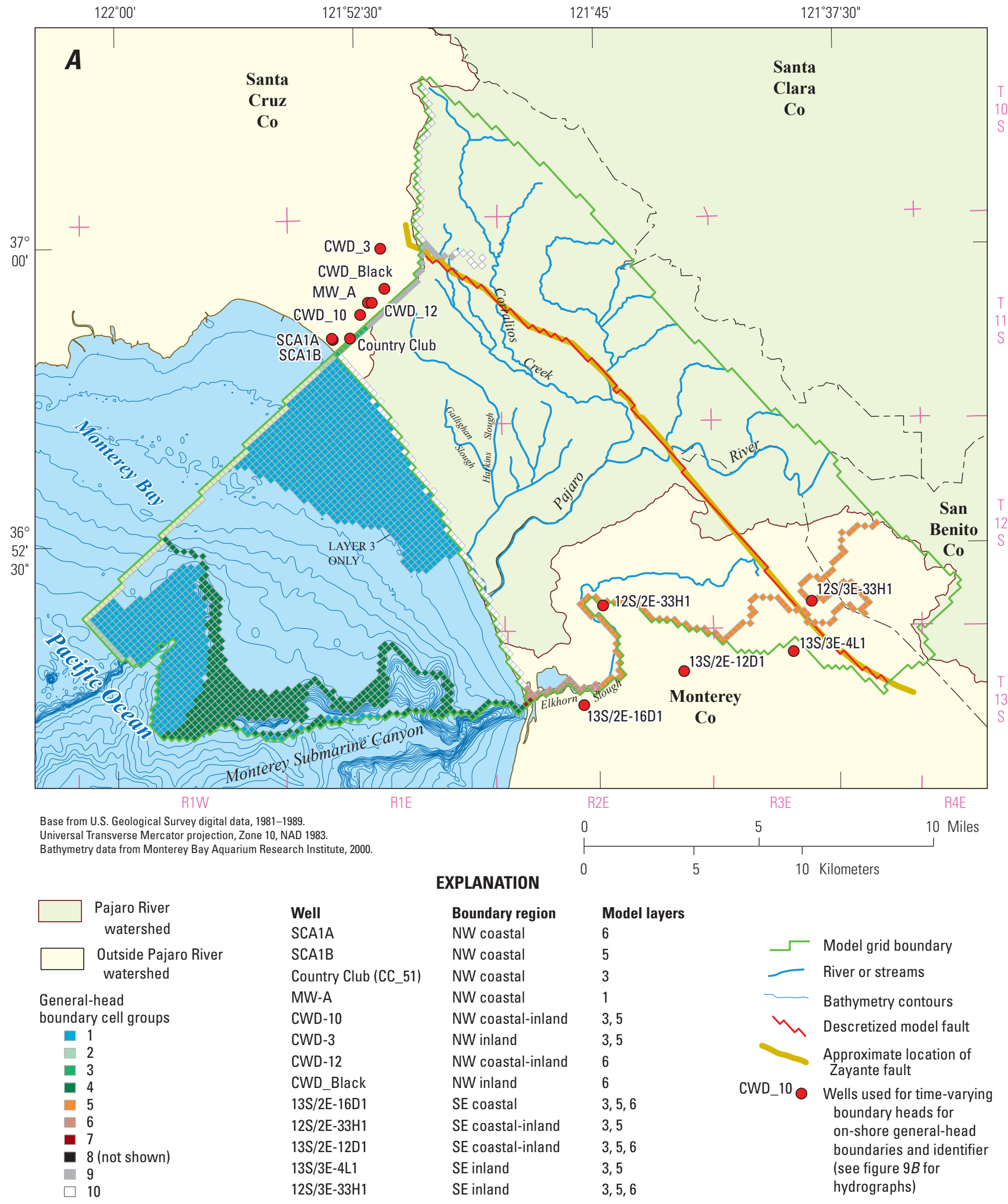

Figure 9. A, Distribution of general-head boundaries for aquifer layers; $B$, hydrographs of general head boundaries (GHB) and sea level; and $C$, distribution of tile-drain agricultural land, Pajaro Valley, California. 
B
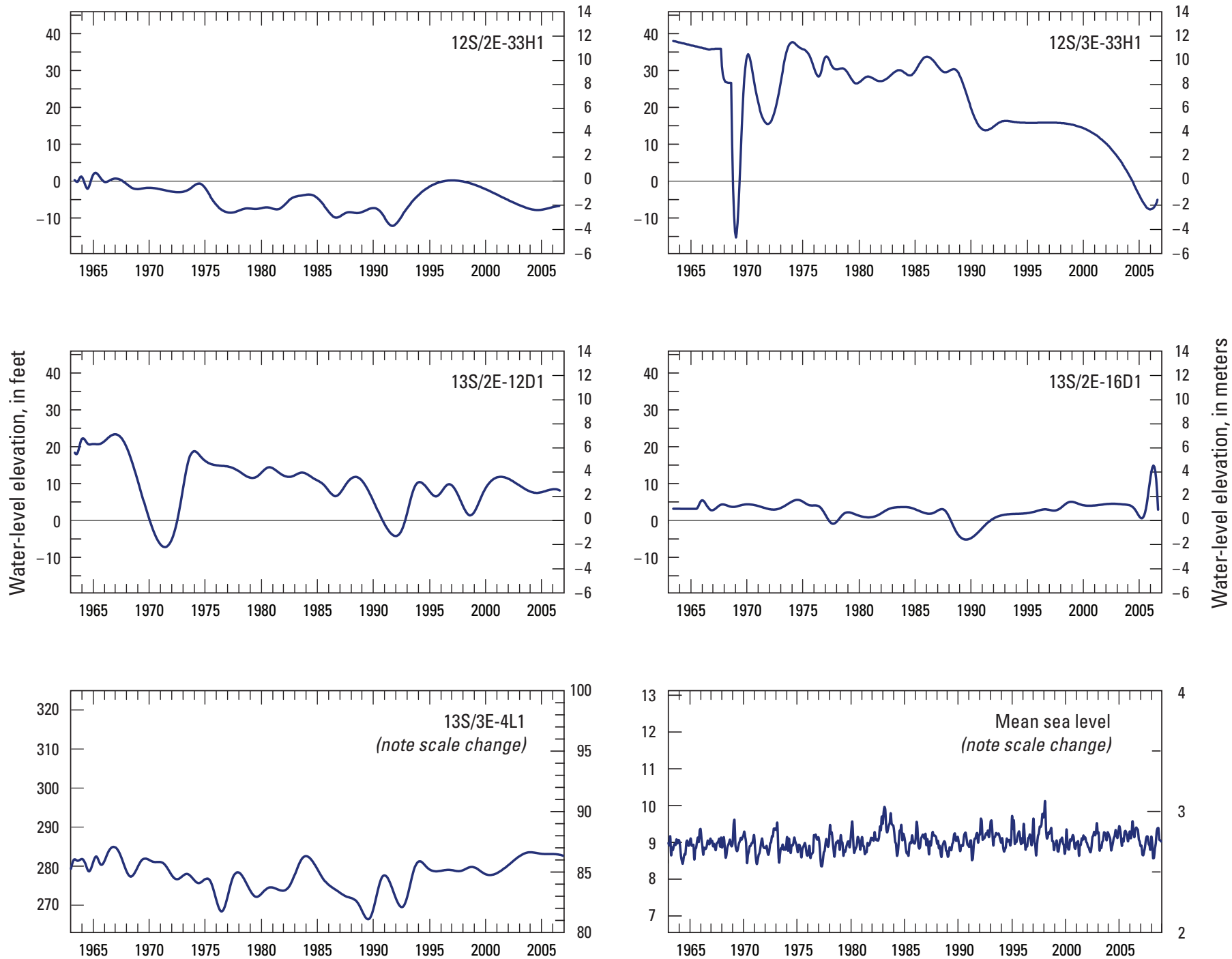

Year

Figure 9. - Continued 


\section{$\boldsymbol{B}$ (Continued)}
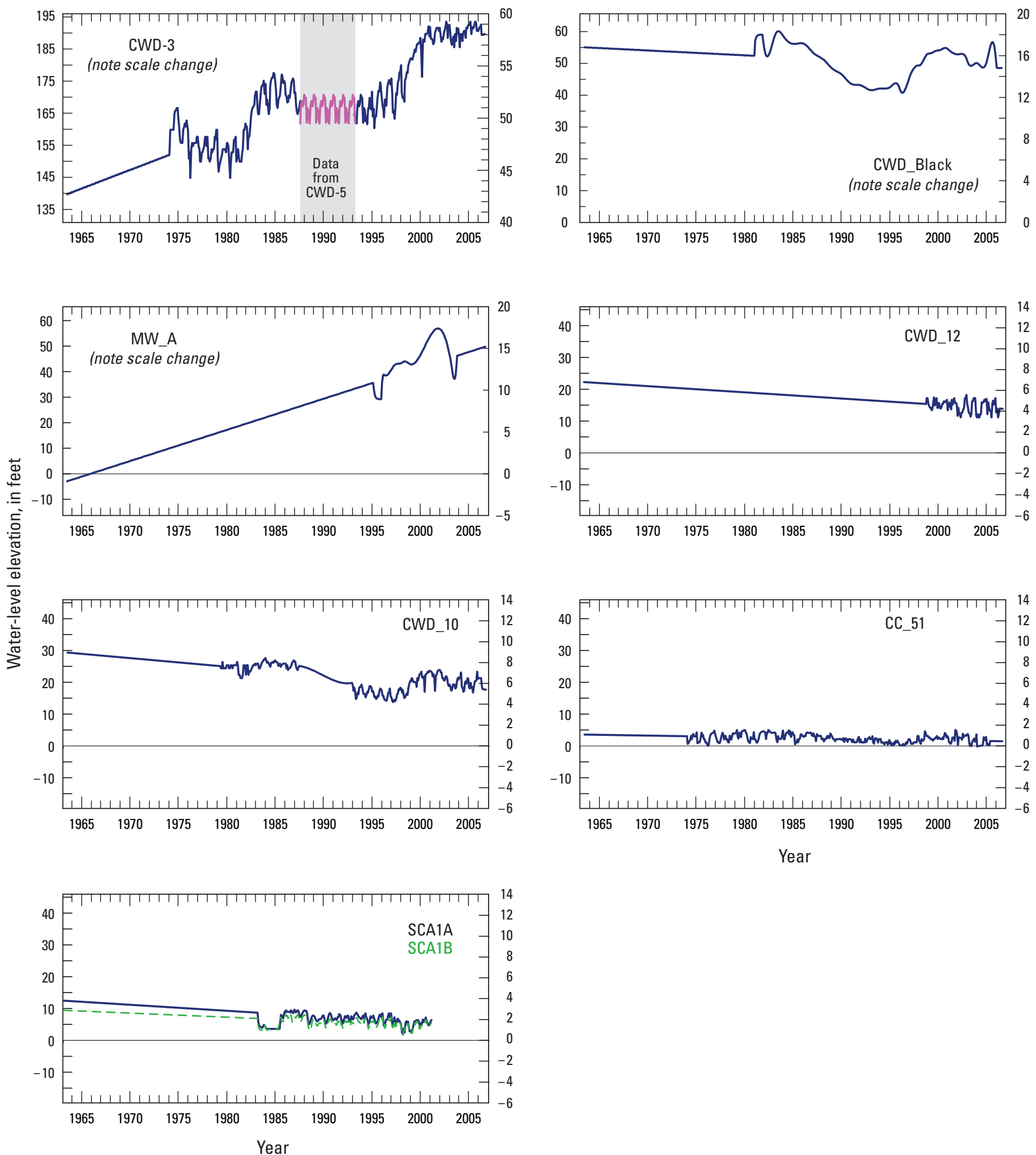

Figure 9. - Continued 


\section{Surface-Water Inflows and Outflows}

Surface-water inflows and outflows were simulated with a streamflow routing network composed of 55 stream segments representing the Pajaro River and Corralitos Creek and their tributaries. This network was used to simulate the inflows and outflows along the major streams, and streamflow diversions (fig. 10). The streamflow routing network also includes the separate drainage of Carneros Creek to Elkhorn Slough. These features were simulated using the Streamflow Routing Package (SFR2; Niswonger and Prudic, 2005; Prudic and others, 2004); this head-dependent boundary condition allows for streamflow routing and the conveyance of overland runoff, groundwater discharge (gaining stream reaches), streamflow infiltration into the aquifer (losing stream reaches), base flow as groundwater discharge (gaining stream reaches), and the diversion of water for water supply or irrigation.

The SFR2 package accounts for water that is routed through stream networks from the inflow of the Pajaro River through Chittenden Pass and the headwaters of local tributaries and creeks to the Pacific Ocean. This routing capability facilitates the simulation of streamflow, streamflow diversions, overland runoff, and the infiltration (recharge) and exfiltration (discharge) of water into and out of the groundwater flow system on a cell-by-cell basis. The streamflow routing network was modified, corrected, and expanded over the network used in the previous PVIGSM model to facilitate the major tributaries, creeks, and sloughs that may provide conveyance for overland runoff. Runoff estimated by FMP2 is redirected to the streamflow networks and provides a substantial component of groundwater recharge, streamflow discharge, and streamflow diversions. The stage-discharge relations were assumed to be constant for each group of river cells, called river segments (fig. 10), and were derived from the previous PVIGSM model (Teghavi, and Smith, 1999a). The streambed elevations for the beginning and end of each segment are specified along with the streambed thickness, and the vertical hydraulic conductivity of reaches (cells) within each segment.

The streamflow network has a total of 16 inflow points, which were specified on the basis of data from USGS gaging station Pajaro River at Chittendon (No. 11159000), and data from the station Corralitos Creek near Corralitos (No. 11159150) that was split based on fractions of watershed area between the West Branch of Corralitos Creek and Shingle Mill Gulch (fig. 5). Previous estimates of ungaged flow from Brown's and Casserly Creeks (fig. 5) were extended from the precipitation-runoff relations established from the previous PVIGSM model (Teghavi, and Smith, 1999a). The streamflow for Green Valley Creek was not included in previous models and was added to this model. The streamflow record was extended from the discontinued gaging station Green Valley Creek (No. 11159400) using measured data for 1963-67 and a regression relation between measured flow at Green Valley Creek and estimated flow in Brown's Creek. The constant inflows specified in the previous PVIGSM model at ungaged Hughes, Salsipuedes, and Coward Creeks, and for Shingle Mill, and Mattos Gulches were transformed into area-weighted time-varying flows from the estimated flows at Brown's Valley Creek. Additional ungaged inflow points were specified with no inflow, including Carneros Creek; three small tributary creeks below the confluence of the West Branch of Corralitos Creek and Brown's Creek; and above the USGS gaging station on Corralitos Creek at Freedom for three ungaged local tributaries, str425, str484, str532, derived from the USGS national hydrography data set (http://nhd.usgs.gov/; fig. 5). These tributaries were added to the model because field observations indicate that they may provide significant runoff and base flow to Corralitos Creek. Harkins and Watsonville Sloughs were also specified with zero inflow. FMP2 was used to simulate overland runoff in these watersheds and capture of local runoff to supply the HS-ASR.

Three diversions were specified in the PVHM model. The diversion of streamflow for water supply by the $\mathrm{CW}$ was simulated by two diversions. The previous PVIGSM model had the diversion of streamflow on Corralitos Creek at the Filter Plant as a single composite diversion. In the current model, these diversions were relocated to the actual points of diversion on the West Branch of Corralitos Creek and on Brown's Creek. The specified diversions were based on individual monthly historical data provided by the CW (Keith Kimes, City of Watsonville, written commun., 2006). The composite diversion data were split between the diversions on the West Branch of Corralitos Creek and Brown's Creek by fractions of 95 and 5 percent, respectively. The third diversion represents the more recent diversions from Harkins Slough by PVWMA for the period 2002-09, with monthly diversions specified at this location. All diversions specified with SFR are based on reported historical diversions for each month. The simulation of the diversion is set to take all water available up to the amount specified and the 'observation' is the amount of water allowed to be withdrawn, versus the amount of water desired to be withdrawn. This approach yields points of diversion that are dependent on the streamflow conveyance of the routing network upstream of the point of diversion. As such, the ability to satisfy the diversions is analogous to a downstream gaging station and these data were used as additional observations during model calibration. 


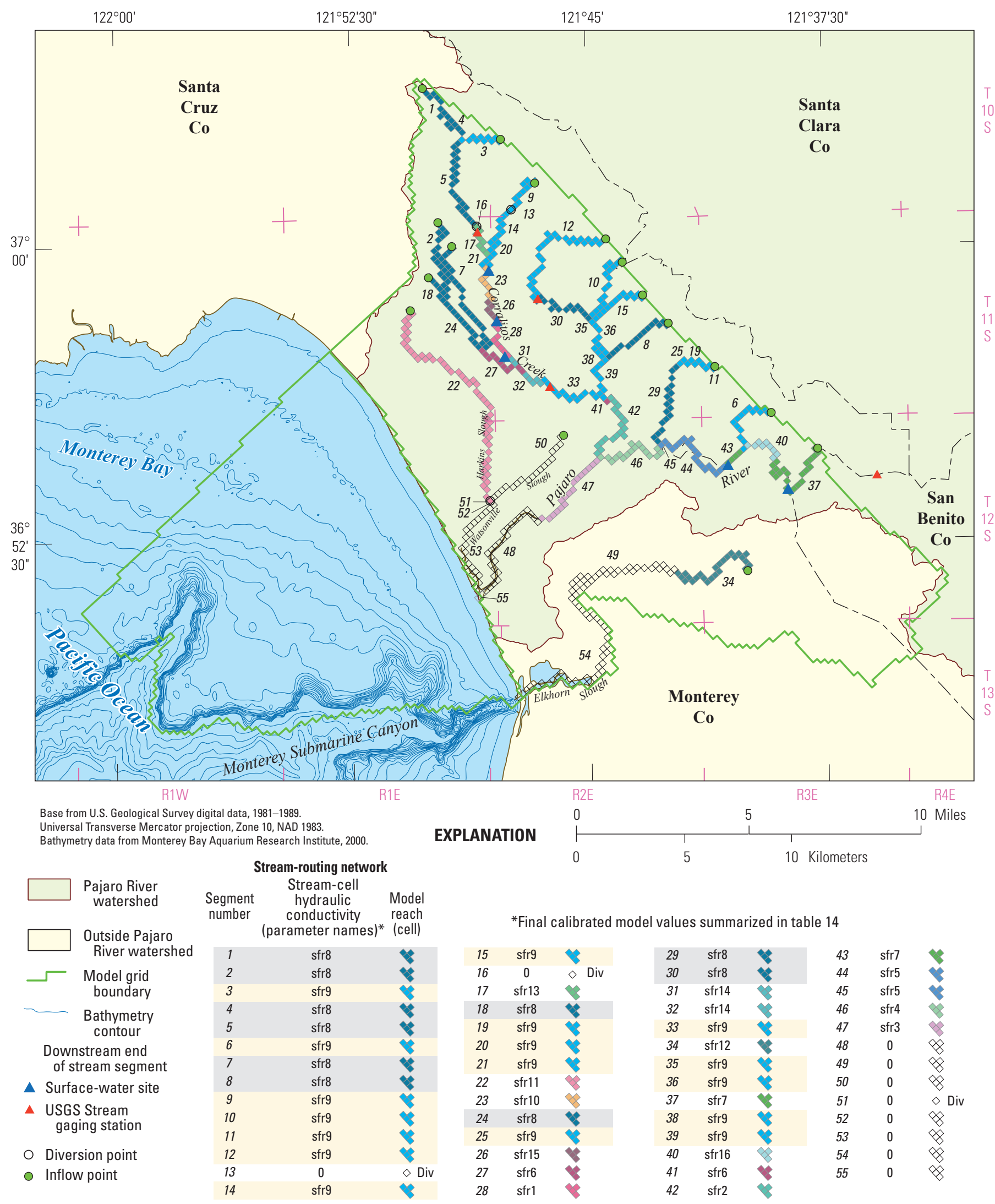

Figure 10. Distribution of model cells used for streams, colored by conductance values of model cells estimated during calibration (color ramp warmer colors higher conductance, see table 14). 
Through linkages with the FMP2, SFR2 also provides simulation of deliveries to the HS-ASR system from the Harkins Slough diversions, channeling of runoff from precipitation, and irrigation runoff and urban runoff. The remainder of the streamflow that does not infiltrate to become groundwater recharge, or is not diverted and consumed for agriculture, flows out of the Pajaro River and Watsonville Slough directly into Monterey Bay near Palm Beach, and out of Carneros Creek into Elkhorn Slough (figs. 5, 10). The hydraulic conductance of the streambed in each stream segment is dependent on stage, width, and flow relations (that is, the area), and the related streambed vertical hydraulic conductivity of the streambed. The streambed hydraulic conductivities were initially set to a zero value below an elevation of $6 \mathrm{~m}$ above mean sea level to prevent the streams from acting as regional drains to the groundwater system or promoting coastal inflow that could represent seawater intrusion. This approach is consistent with the distribution of fine-grained layers that generally prevent vertical flow in the outflow reaches of coastal stream networks. The remaining streambed hydraulic conductivities were grouped into 17 groups of stream segments with similar characteristics that were adjusted during model calibration (fig. 10).

\section{Groundwater Pumpage}

Groundwater pumpage is a major component of the hydrologic budget of Pajaro Valley, and is grouped into two categories for this study, agricultural and (other) water supply. Agricultural pumpage, which is estimated using FMP2, includes withdrawals from all farm wells used to supply water for irrigation. Water-supply pumpage includes withdrawals from wells used for municipal, domestic/rural-residential, and industrial purposes. Farm wells were simulated as a combination of single-aquifer wells (Schmid and others, 2006a) and multi-node wells (MNW; Halford and Hanson, 2002) that collectively supply water needed for irrigation for each WBS and monthly stress period (fig. $6 A$ ). Farm wells that are single-aquifer wells are simulated as in the WEL package (Harbaugh and others, 2000) and the total pumpage for each WBS (that is, virtual farm) is distributed among each of the farm wells within the WBS based on the fraction of total pumping capacity (Schmid and others, 2006a). Municipal pumpage for urban water supply is specified on the basis of reported values, and domestic pumpage was estimated from reported values (fig. 7). A subset of farm wells, all municipal wells, and some mutual water company wells are simulated as MNW wells that "pump" water from 1 to as many as 4 aquifer model layers.

\section{Agricultural Supply}

Discharge from agricultural wells has been metered in the Pajaro Valley since about 2000, when wells that pump greater than 10 acre-ft per year were required to have a flow meter installed and the well owners were required to report metered pumpage to PVWMA for payment of augmentation fees. However, an indirect method must be used to estimate unmetered pumpage for the period 1963-99. The two most common methods of indirectly estimating pumpage are through power consumption and consumptive use of water. Many well pumps are operated by either electric or diesel power sources. With the inherent complexity of additional uses for electricity on a farm-by-farm basis, the use of electric power records is considered unreliable for estimating pumpage. Consumptive use (CU) is defined by the USGS as that part of withdrawn water that is evaporated, transpired, incorporated into products or crops, consumed by humans or livestock, or otherwise removed from the immediate water environment (U.S. Geological Survey, 2010). Many estimates of CU are also considered uncertain because they typically do not account for the combined consumption of precipitation, water applied for irrigation, and direct uptake from groundwater, and do not capture the variability in consumption with climate.

For this study, FMP2, which does account for the above factors, was used to estimate unmetered pumpage for agricultural supply. This pumpage is estimated as a combination of crop irrigation requirement and inefficiency losses. The resulting total farm delivery requirement for a particular WBS is then distributed among all wells in the WBS. Inefficiency losses include those from on-farm conveyance of irrigation water and losses from runoff and deep percolation below the root zone during irrigation. The crop irrigation requirement refers to all evaporation and transpiration of water by various crop types, as determined using a suite of land use estimates for selected periods (table 2). The crop irrigation requirement is a component of the total consumptive use. Total consumptive use is the water consumed by evaporation and transpiration from all sources of water. Groundwater pumpage needed to satisfy total farm delivery requirement can be estimated by taking into account any surface-water supply, the efficiency of irrigation, effective precipitation, fractions of transpiration and evaporation within each model cell, and the fractions of inefficiency losses to runoff and deep percolation, as well as direct uptake of groundwater. Because most irrigation water in the Pajaro Valley is supplied by pumping from wells, surfacewater supplies become a factor only with the implementation of the CDS for the period 2002-09. Pumpage for irrigation was simulated for 1,032 farm wells in their actual locations; the number of active wells varied through time on the basis of drill dates and destruction dates (fig. 6 ). Reported pumpage for the period 2002-09 was used for selected WBS as calibration data. 
Pumpage was allocated to the model layers according to the construction information available from PVWMA databases. The open screen interval was used to identify the model layers from which pumping occurred. Specifically, the top and bottom of the open interval for each cell was assigned based on well construction records in the cell, although the model assumes full penetration of each layer. The FMP2 allocated pumpage to each well is based on the average pumping rate required for all the wells serving a WBS as a fraction of the total pumping demand but does not exceed the pumping capacity of any individual well. The capacity of the farm wells ranges from 250 to 1,500 gallons per minute and the casing diameters range from 7 to 16 in. In addition, for the CDS recovery wells at the ASR system and supplementary and blend wells that also serve water to the CDS regions that are simulated using MNW, the MNW head limit was initially set at an elevation above the pump bowls and was modified during calibration if necessary.

\section{Water Supply}

Pumpage values for municipal water supply were based on reported monthly to annual metered values on a well-by-well basis for CW, SCWD, and selected mutual water companies; estimates of domestic pumpage were also reported. The actual locations of municipal-supply and domestic wells were used in the model. Data from as many as 25 municipal and mutual wells, and up to 1,695 domestic wells, were used to simulate pumpage for drinking water and industrial water supply (fig. 6). The MNW package was used to simulate pumpage from all municipal-supply wells, which tend to tap multiple aquifers. The open screen interval or total depth was used to identify the model layers from which pumping occurred. The well package was used to simulate the domestic pumpage from single model layers. The number of domestic wells varies for each stress period and was determined by drilling and destruction dates when available; domestic wells were otherwise assumed to be in existence and being pumped for the entire period of simulation. The pumpage from each domestic well was initially estimated to be about 0.6 acre-ft/yr, but was rescaled to reported rural residential usage over the respective wells for the period 1999-2009 to match the reported total estimate of domestic pumpage from PVWMA. The reported domestic pumpage has decreased in recent years, from 1,883 acre-ft/yr in 1999 (1.2 acre-ft/yr per well) to 1,465 acre-ft/yr in 2009 (0.96 acre-ft/yr per well; fig. 7). The reported domestic pumpage has decreased in recent years owing to refinements in the reporting and estimation process.

\section{Landscape Use and Movement of Water}

The FMP2 provides coupled simulation of the groundwater and surface-water components of the hydrologic cycle for irrigated and non-irrigated areas (fig. 8). A dynamic allocation of groundwater recharge and pumping is simulated on the basis of residual crop-water demand after surface-water deliveries and root uptake from shallow groundwater. The estimation of irrigation pumpage in FMP2 is also dependent on contributions of water from precipitation and variable irrigation efficiencies. The FMP2 not only estimates supply and demand, movement, and consumption for agricultural irrigation water but also estimates these components for natural vegetation and for landscape irrigation in urban areas. Thus, the use and movement of water on the landscape is fully coupled with streamflow and groundwater flow, and is dependent on atmospheric conditions through precipitation and $\mathrm{ET}_{\mathrm{h}}$.

MF-FMP2 simulates the demand components representing crop irrigation requirement that are subject to crop and farm-specific inefficiency losses, and the supply components representing surface-water deliveries and supplemental groundwater pumpage. The FMP2 also simulates additional head-dependent inflows and outflows from the landscape such as surface runoff from precipitation and surface-water return flows to the streamflow network, and groundwater recharge as deep percolation of water in excess of actual evapotranspiration $\left(\mathrm{ET}_{\mathrm{act}}\right)$ and runoff (Schmid and others, 2006a,b; Schmid and Hanson, 2009).

The MF-FMP2 allocates water, simulates processes, and computes the surface-water and groundwater inflows and outflows as mass balances for each WBS for each time step (Schmid and others, 2006a,b; Schmid and Hanson, 2009). The FMP2 first calculates crop water demand as the plant transpiration and related evaporation, which are dependent on simulated conditions in the root zone (conditions approaching anoxia or wilting reduce crop water demand). The FMP2 then determines a residual crop water demand that cannot be satisfied by precipitation and root uptake directly from groundwater, if available. On a cell-by-cell basis, the FMP2 then equates this residual crop water demand with the crop irrigation requirement (CIR) for the cells with irrigated crops (that is, exclusive of any natural vegetation).

The CIR is then adjusted (increased) by accounting for evaporative losses from irrigation and other inefficiency losses to yield a final total farm delivery requirement (TFDR). The FMP2 then attempts to satisfy the TFDR using surface water, if available. The water delivered through the pipelines of the CDS in 2002-09 is simulated independent of the actual conveyance and is referred to here as "non-routed." Water routed through the stream network that is diverted at Harkins Slough in 2002-09 and delivered to the ASR system is referred to here as a "semi-routed." Overall, the non-routed deliveries are used first to satisfy the TFDR. Lastly, the FMP2 determines the amount of supplemental groundwater pumping necessary to satisfy the TFDR if the TFDR is not met by these other sources. The amount of excess water from irrigation and/ or precipitation that is not effectively used for crop growth then becomes either overland runoff to nearby streams or groundwater recharge as deep percolation below the root zone. Thus, the FMP2 dynamically links the demand, supply, and 
related change in aquifer storage (fig. 8). All of the supply and demand components are then tabulated into a WBS budget that complements the ground-water-flow and streamflow budgets that collectively represent the hydrologic cycle.

In order to do these calculations, the FMP2 integrates supply and demand data that can be specified over time, or held constant for the entire simulation. The FMP2 requires soil, crop, and climate data to compute consumptive use. Similarly, deliveries and well data are needed to estimate the semi-routed and non-routed surface-water deliveries, return flow locations, and the groundwater pumping requirements, respectively.

The FMP2 dynamically simulates these supply and demand components for a WBS within MF2005 by integrating the following generalized computational components (fig. 8):

1. Total Farm Delivery Requirement (TFDR), which is largely dependent on the Crop Irrigation Requirement (CIR) but also depends on efficiency, changing climate (ET and precipitation), and variable aquifer head;

2. Actual surface-water delivery to the WBS, which may be driven by TFDR, but limited by canal/stream inflow rates at the WBS's diversion head gate, or by allotments, or by semi- or non-routed deliveries;

3. Supplemental groundwater pumpage, which is estimated as the TFDR minus the actual surface-water delivery, but is limited by the summation of specified maximum WBS well-pumping capacity on a well-by-well basis; and

4. Net recharge (deep percolation) to groundwater, which is taken to be the sum of excess irrigation and precipitation minus the sum of surface-water runoff from precipitation and irrigation and ET from groundwater.

The MF-FMP2 maintains a mass balance for each WBS, for the streamflow network, and for the groundwater flow system (fig. 8). Flows between these hydrologic components are accommodated by head-dependent inflows and outflows. Quantities of interest, such as TFDR, surface-water and groundwater supply, and excess applied irrigation water depend on these head-dependent inflows and outflows.

For the PVHM, the processes of evaporation, transpiration, runoff, deep percolation to groundwater, and groundwater pumpage were estimated using MF-FMP2. The simulated changes in deliveries and groundwater pumpage during the 1963-2009 simulation period reflect climatic differences, differences in the characteristics of defined waterbalance subregions, and changes in the water-delivery system Because irrigation in Pajaro Valley is predominantly supplied from groundwater, coastal surface-water deliveries become a part of the simulation only with operation of the CDS during the last eight years of the simulation period (2002-09). The model provides a detailed transient analysis of changes in groundwater availability in relation to climatic variability, urbanization, and changes in irrigated agriculture.

\section{Delivery Requirement}

The TFDR is determined as consumptive use by irrigated crops and increased to account for inefficiency losses in all model cells within a WBS. In order to calculate the components of the water budget, the FMP2 also requires estimates of ET as a whole and fractions of ET attributed to irrigation and direct use of groundwater by plants. Groundwater uptake by individual crops from each WBS is simulated using transpiration rates approximated in FMP2 by an analytical solution that accounts for changes in transpiration rates with changes in depth to the groundwater table. The amount of evaporation and transpiration from the groundwater table are functions of water-table elevation, the root depth of each crop type, and the user-specified anoxia and wilting point of each crop. Therefore, the TFDR requires soil, land use (specifically distribution of crop types), and climate data to compute consumptive use on a cell-by-cell basis.

\section{Soils}

The PVHM soils were simplified into sandy loam, silty clay, and silt on the basis of data from the Soil Survey Geographic Database (SSURGO; U.S. Department of Agriculture Natural Resources Conservation Service, 2005; fig. 11). The thickness of the capillary fringe estimated for each soil type ranges from 4 to $6 \mathrm{ft}$. These soil attributes are used for the entire simulation period and the cell-bycell distribution is independent of the crop and WBS. The FMP2 associates the distributed soil types with the specified capillary fringes and internal coefficients that allow individual analytical solutions for the calculation of evapotranspiration as a function of depth to water (Schmid and others, 2006a).

\section{Land Use}

The FMP2 can be used to estimate components of consumptive use for a wide variety of land-uses, including vegetation in irrigated or non-irrigated agriculture, fallow fields, riparian or natural vegetation, and urban landscape settings. Likewise, FMP2 can be used to simulate an assortment of irrigation settings that span the spectrum from flooded fields such as those planted in rice and cotton, to drip irrigation of truck crops, strawberries, and orchards. The FMP2 also can be used for applications with zero transpiration, such as artificial recharge systems (ASR systems).

For the Pajaro Valley, the land-use attributes are defined on a cell-by-cell basis and include urban and agricultural areas, water bodies, and natural vegetation. The land use that covered the largest fraction of each cell (about 15 acres) was considered the use representative of the entire cell. The PVHM model uses a total of 20 land-use categories that represent 17 agricultural classes, urban vegetation, native vegetation, and water (table 6). Producing maps of land use, including 


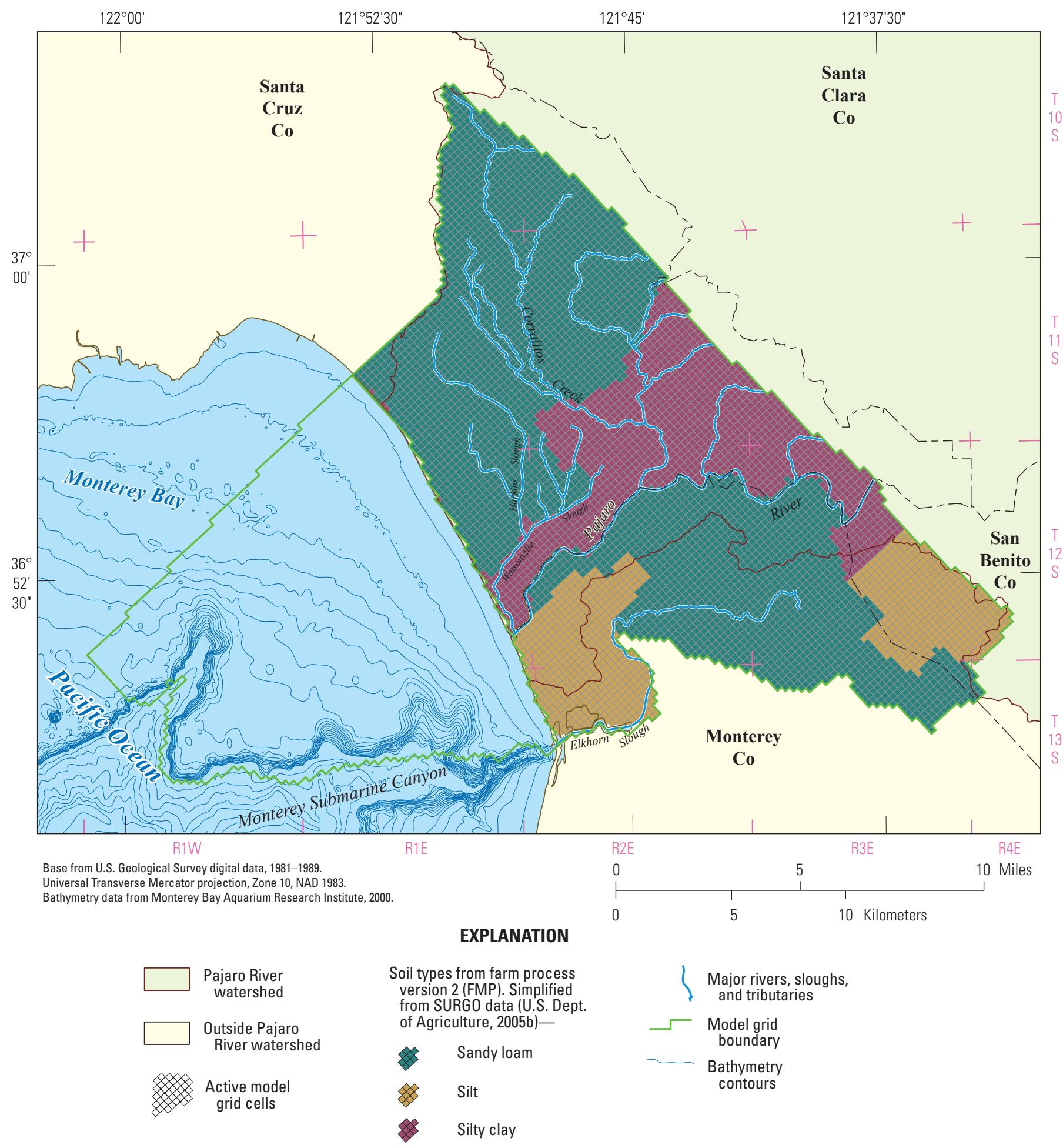

Figure 11. Agricultural soil types for the Pajaro Valley, simplified from Soil Survey Geographic Database (SSURGO; U.S. Department of Agriculture Natural Resources Conservation Service, 2005). 
crops, is problematic because of complex spatial patterns that change rapidly over time in the dynamic environment of modern agricultural practices. Despite their uncertainty and complexity, land-use maps were developed for seven periods spanning the period of simulation. Most of these maps were based on interpreted high-altitude aerial photography. Landuse changes may occur gradually or rapidly in response to changes in climate, urbanization, zoning, or farming practices. These changes required making decisions as to how to approximate the changes over time in the modeled domain. For this simulation, the seven land-use patterns were generally aligned with the climate cycle with which they coincided (table 2, fig. 4A).
Most of the valley floor is developed agricultural land (table 6). This agricultural land was further subdivided into agricultural classifications. The agricultural classifications are based on the CADWR 12 class-1 categories that represent groups of crops with similar water consumption and growth stages (California Department of Water Resources, 2000). The 12 class- 1 categories were augmented with more general classes for earlier years, when the delineation of land use was less detailed (table 3 ). In general, the 12 class-1 categories represent groups of vegetation that have similar amounts of water consumption and similar growth cycles that drive their consumption of water. Because of the interest in water use of strawberries, artichokes, and berries (raspberries,

Table 6. Land use periods with acreage in square miles and percentage of different virtual crop categories, Pajaro Valley, California.

\begin{tabular}{|c|c|c|c|c|c|c|c|c|c|c|c|c|c|c|c|c|}
\hline \multirow{2}{*}{ Description } & \multirow{2}{*}{ Irrigated } & \multicolumn{7}{|c|}{ Area (square miles) } & \multicolumn{8}{|c|}{ Percentage of active model area } \\
\hline & & 1970 & 1989 & 1991 & 1993 & 1997 & 2000 & 2006 & 1970 & 1989 & 1991 & 1993 & 1997 & 2000 & 2006 & 2009 \\
\hline $\begin{array}{l}\text { 1. Vegetable row crops } \\
{\text { (truck crops })^{2}}^{2}\end{array}$ & Yes & 18.4 & 27.6 & 27.9 & 7.2 & 16.7 & 15.4 & 13.9 & 12.3 & 18.5 & 18.7 & 4.8 & 11.2 & 10.3 & 9.3 & 8.7 \\
\hline 2. Strawberries & Yes & 8.5 & 4.0 & 4.0 & 16.0 & 11.2 & 10.9 & 12.7 & 5.7 & 2.7 & 2.7 & 10.7 & 7.5 & 7.3 & 8.5 & 9.5 \\
\hline $\begin{array}{l}\text { 3. Artificial storage and } \\
\text { recovery site }\end{array}$ & No & 0.0 & 0.0 & 0.0 & 0.0 & 0.0 & 0.1 & 0.1 & 0.0 & 0.0 & 0.0 & 0.0 & 0.0 & 0.1 & 0.1 & 0.1 \\
\hline 5. Field crops ${ }^{2}$ & Yes & 0.1 & 0.1 & 0.1 & 0.1 & 0.1 & 0.1 & 0.1 & 0.1 & 0.1 & 0.1 & 0.1 & 0.1 & 0.1 & 0.1 & 0.1 \\
\hline $\begin{array}{l}\text { 6. Deciduous trees } \\
\text { (orchards) }\end{array}$ & Yes & 10.6 & 8.1 & 8.1 & 6.4 & 5.7 & 6.0 & 5.5 & 7.1 & 5.4 & 5.4 & 4.3 & 3.8 & 4.0 & 3.7 & 3.4 \\
\hline 7. Subtropical crops ${ }^{2}$ & Yes & 0.1 & 0.1 & 0.1 & 4.5 & 0.1 & 0.1 & 0.3 & 0.1 & 0.1 & 0.1 & 3.0 & 0.1 & 0.1 & 0.2 & 0.2 \\
\hline $\begin{array}{l}\text { 8. Vines (bushberries, } \\
\text { grape, etc.) }\end{array}$ & Yes & 1.9 & 0.3 & 0.3 & 1.2 & 2.7 & 2.7 & 1.3 & 1.3 & 0.2 & 0.2 & 0.8 & 1.8 & 1.8 & 0.9 & 0.4 \\
\hline 11. Turf (urban) & No & 12.9 & 18.1 & 18.1 & 22.0 & 26.2 & 25.9 & 25.9 & 8.6 & 12.1 & 12.1 & 14.7 & 17.5 & 17.3 & 17.3 & 16.6 \\
\hline $\begin{array}{l}\text { 12. Native vegetation / } \\
\text { riparian }\end{array}$ & No & 82.9 & 82.8 & 81.9 & 64.6 & 72.9 & 73.8 & 71.9 & 55.5 & 55.4 & 54.8 & 43.2 & 48.8 & 49.4 & 48.1 & 47.7 \\
\hline 13. Water & No & 1.2 & 0.1 & 0.9 & 4.8 & 1.6 & 1.8 & 1.6 & 0.8 & 0.1 & 0.6 & 3.2 & 1.1 & 1.2 & 1.1 & 1.2 \\
\hline 14. Nurseries & Yes & 1.6 & 0.1 & 0.1 & 2.1 & 3.6 & 3.6 & 3.6 & 1.1 & 0.1 & 0.1 & 1.4 & 2.4 & 2.4 & 2.4 & 2.7 \\
\hline 15. Cropland and pasture ${ }^{3}$ & Yes & 0.0 & 0.1 & 0.1 & 0.1 & 0.1 & 0.1 & 0.1 & 0.0 & 0.1 & 0.1 & 0.1 & 0.1 & 0.1 & 0.1 & 0.1 \\
\hline $\begin{array}{l}\text { 16. Raspberries / } \\
\text { blackberries / } \\
\text { blueberries }\end{array}$ & Yes & 0.1 & 0.4 & 0.4 & 1.6 & 0.0 & 0.0 & 3.7 & 0.1 & 0.3 & 0.3 & 1.1 & 0.0 & 0.0 & 2.5 & 5.1 \\
\hline
\end{tabular}

${ }^{1}$ Semi-agriculture includes livestock feedlots, diaries, and poultry farms.

${ }^{2}$ California Department of Water Resources class-1 categories (California Department of Water Resources, 2000).

${ }^{3}$ Cropland and pasture represent combination of crop groups $1,2,4,5,6,7,8,9,10$, and 16 from "description" in column 1.

${ }^{4}$ Irrigated row and field crops represent combination of crops groups 1 and 5 from "description" in column 1. 
blackberries and blueberries), these crops are delineated separately on the land-use maps when data are available. Groups of similar crops are herein referred to as "virtual crops." The virtual crops are defined from eight land-use maps for 1970, 1989, 1991, 1993, 1997, 2000, 2006 and 2009 (tables 2, 6; figs. 12-18). Each virtual crop is represented by an index number in the FMP2 (table 6). Some of the virtual crops are amalgamations of the others (table 6 , grouping of other classes) for selected years and sources of land-use maps. For example, the virtual crop "cropland and pasture" is an amalgamation of other more detailed virtual crops (table 6). Because the virtual crop maps for the earlier periods are more generalized, some of the more permanent or more established crop types such as native vegetation and orchards that were mapped more recently are assumed to be active earlier and are embedded on the basis of the most recent land-use period (2006).

\section{Virtual Crop Maps}

For the period 1963-82, land use was interpreted using the Anderson level II classifications (Anderson and others, 1976) for the 1970 land-use map (fig. 12), and stored in the Geographic Information Retrieval and Analysis System (GIRAS; USGS, 1990). Although the map is referred to as a 1970 land-use map, it is actually based on imagery acquired from the mid-1970s to the early 1980s (USGS, 1990). The 1970 map includes nineteen vegetation classes that matched eight of the PVHM virtual crops (fig. 12). Five of these classes are different types of native vegetation, and six classes represent developed land use. Because of this generalized classification, the agricultural virtual crop classes were replaced with the virtual crop of identical extent from the 2000 virtual-crop map. For example, where only "cropland" was specified in 1970, the virtual crops interpreted on the 2000 map were embedded in the 1970 map. This assumes the same type of crop was grown in a given area specified with the category "cropland" was replaced when present over the time frame of the hydrologic simulation until replaced with other crops from more recent land-use maps. In some cases, such as orchards that require a long growth period and a substantial long-term investment, this is generally a good assumption; in other cases, the crops may have changed several times. Despite the general nature of the map, approximately 56 percent of the valley was covered by native vegetation, 35 percent was agricultural land and 9 percent was urban land (fig. 12).

For the period 1983-90, land use was based on the North American Land Class Data 1992 (NLCD) for the 1989 landuse map (fig. 13), a 21-class hierarchical modified Anderson
Land Cover Classification (USGS, 1999). The NLCD 1992 data are derived from images acquired by Landsat's Thematic Mapper (TM) sensor, as well as a number of ancillary data sources. Although the map is referred to as NLCD 1992, it represents land use for earlier years and is actually based on imagery acquired throughout the 1980s (USGS, 1999). It was the first national land-cover data set produced since the early 1970s. NLCD 1992 data are an improvement over GIRAS data in that the agricultural areas, in which herbaceous plants constitute all ground cover (Cropland and Pasture; Anderson Level II), are subdivided into four NLCD classes: Pasture/Hay, Row Crops, Small Grains and Fallow. The 30-m resolution of the raster-based NLCD was enhanced with GIRAS data to better represent orchards and residential areas (Gilliom and others, 2006). In addition, land-use data for the Salinas Valley and northern Monterey County was obtained from CADWR for 1989-91. These maps show detailed classification (including crop types) for agricultural uses, though fewer classes for urban uses. The detailed classifications are missing in the northern (majority evergreen forest) and eastern portions of the valley. In this combined map, approximately 55 percent of the valley was covered by native vegetation, 33 percent was agricultural land, and 12 percent was urban land use (fig. 13). Urban areas and agricultural land are predominantly on the valley floor. Most orchards are on the north side of the valley.

For the 1991 land-use map, land cover for Santa Cruz and northern Monterey County was interpreted from 1986 and 1993 Landsat TM images using NOAA's Coastal Change Analysis Program (CCAP) protocol (Geiben, 1998; fig. 14). These data provided good definition of cultivated versus noncultivated areas, but contained very little crop information. Where only deciduous crops (orchards) were specified, the crop classifications were updated based on the land use from the 2000 land use map. Where data were missing, the 1989 land use map was used. Approximately 55 percent of the valley was covered by native vegetation, 33 percent was agricultural land, and 12 percent was urban land (fig. 14).

For the 1993 land-use map, data were obtained from 1990 and 1993 Landsat TM images (fig. 15). These data were digitized by the California Coastal Commission (CCC) for their Watershed Analysis Tool project (Geiben, 1998). Although detailed throughout most of the valley area, the maps have limited crop information near the river and often conflict with previous maps, especially in the classification of pasture. The largest discrepancy, however, occurs in the classification of urban areas, where excessive urban areas are mapped by the CCC. To correct this problem, where land on this map was classified as urban, the 1991 land-use map was used to replace the urban categories. In addition, where the 1997 and 1991 land use maps did not have corresponding 


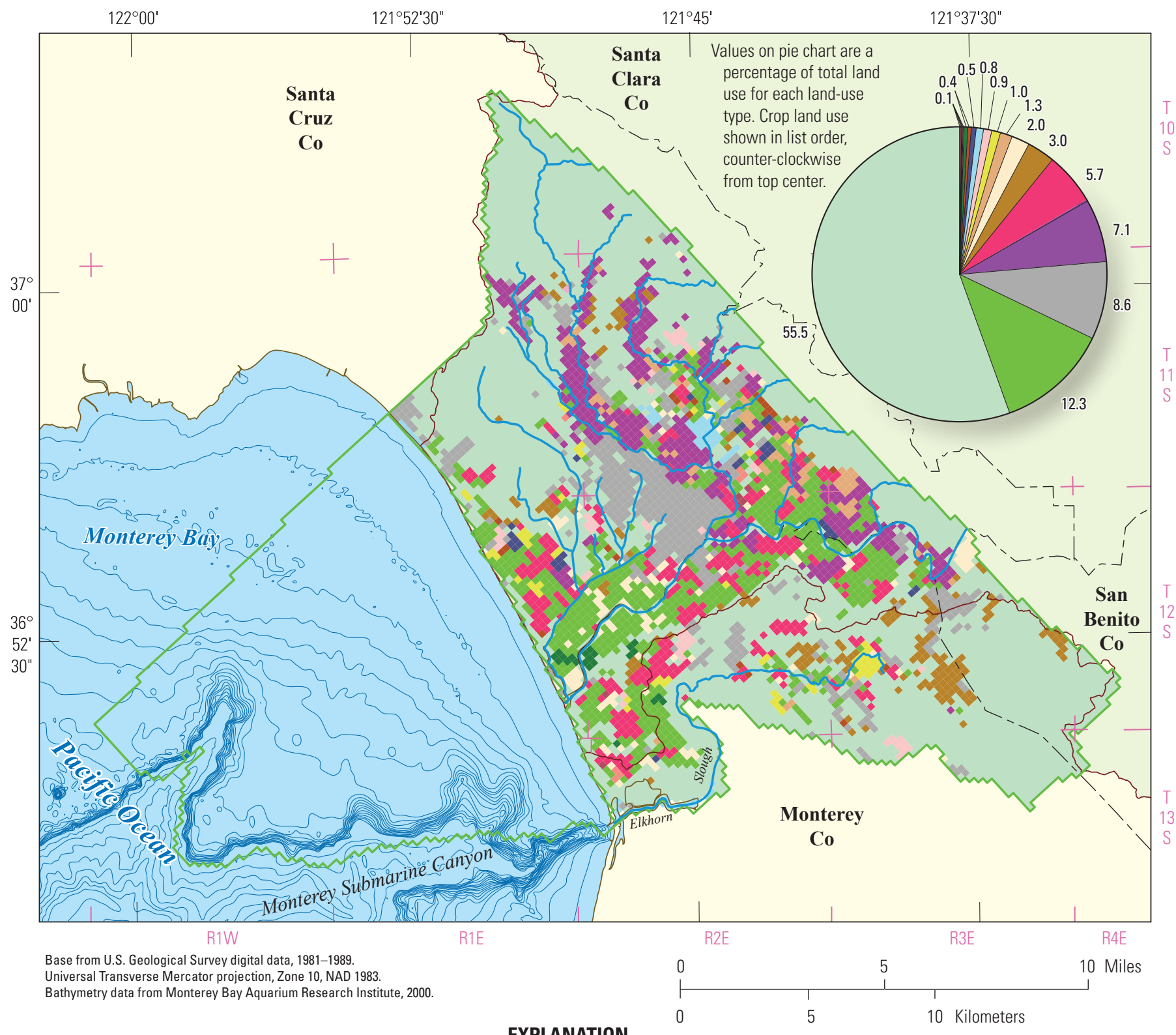

EXPLANATION

Model cell crop land use, 1970 (Modified from U.S. Geological Survey, 1990; California Department of Water Resources, 2000)
Pajaro Rive
Outside Pajaro River watershed

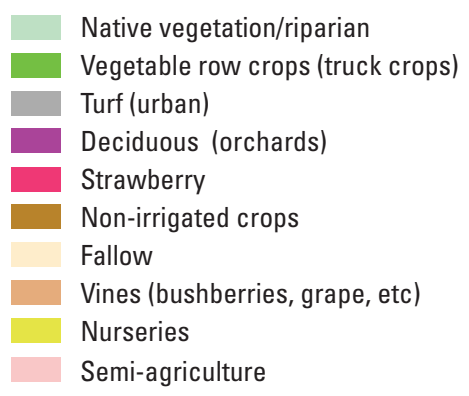

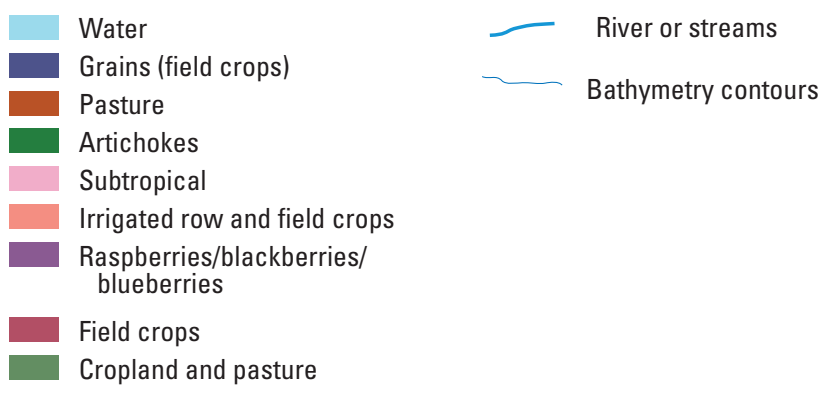

Figure 12. Land-use (virtual crop) groups discretized to model grid for 1970 (modified with 2000 data) and pie chart of percentages of total land use over model area (sources: Geographic Information Retrieval and Analysis System Data), Pajaro Valley, California. 


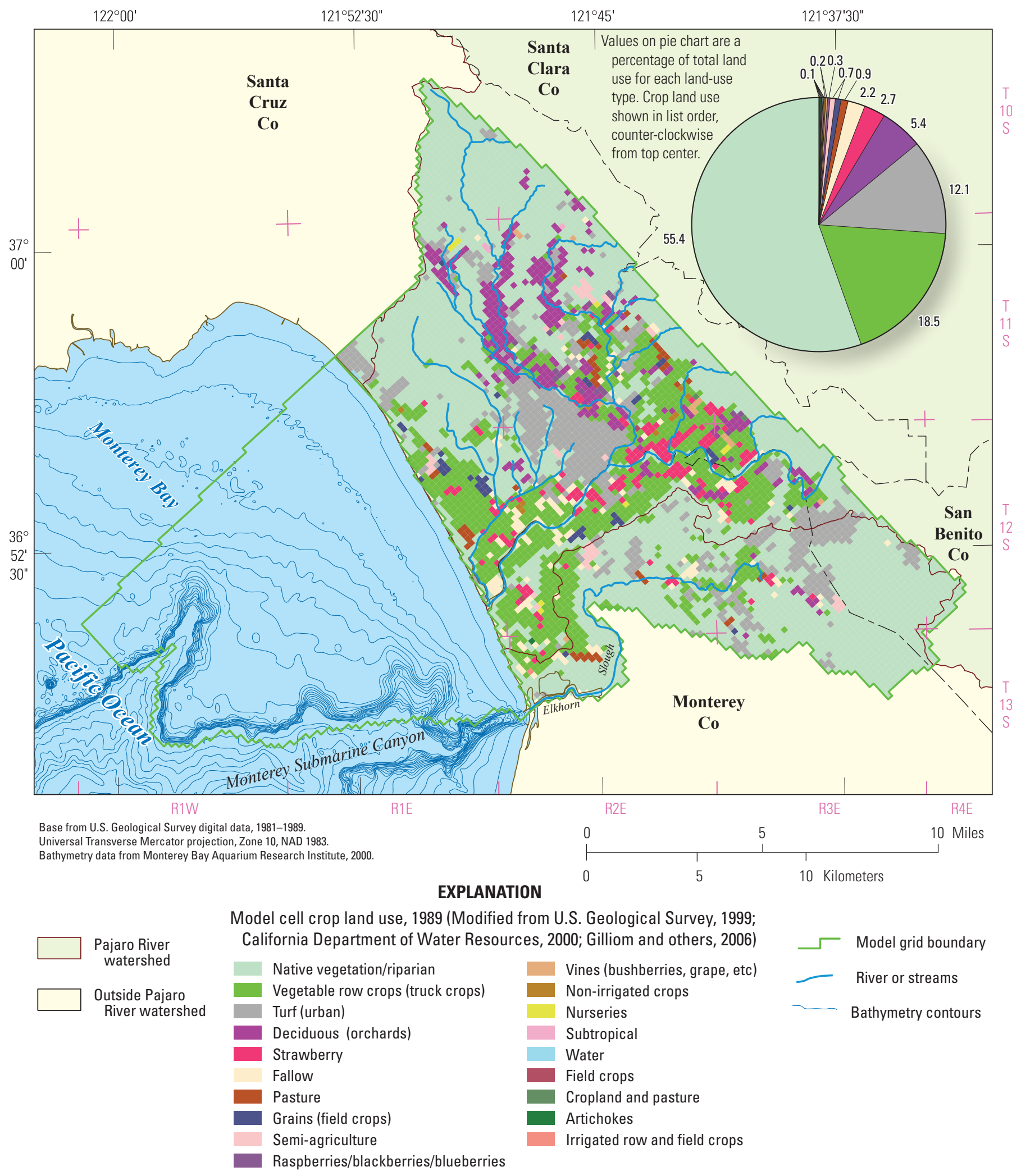

Figure 13. Land-use (virtual crop) for 1989 and pie chart of percentages of total land use over entire model area, Pajaro Valley, California. 


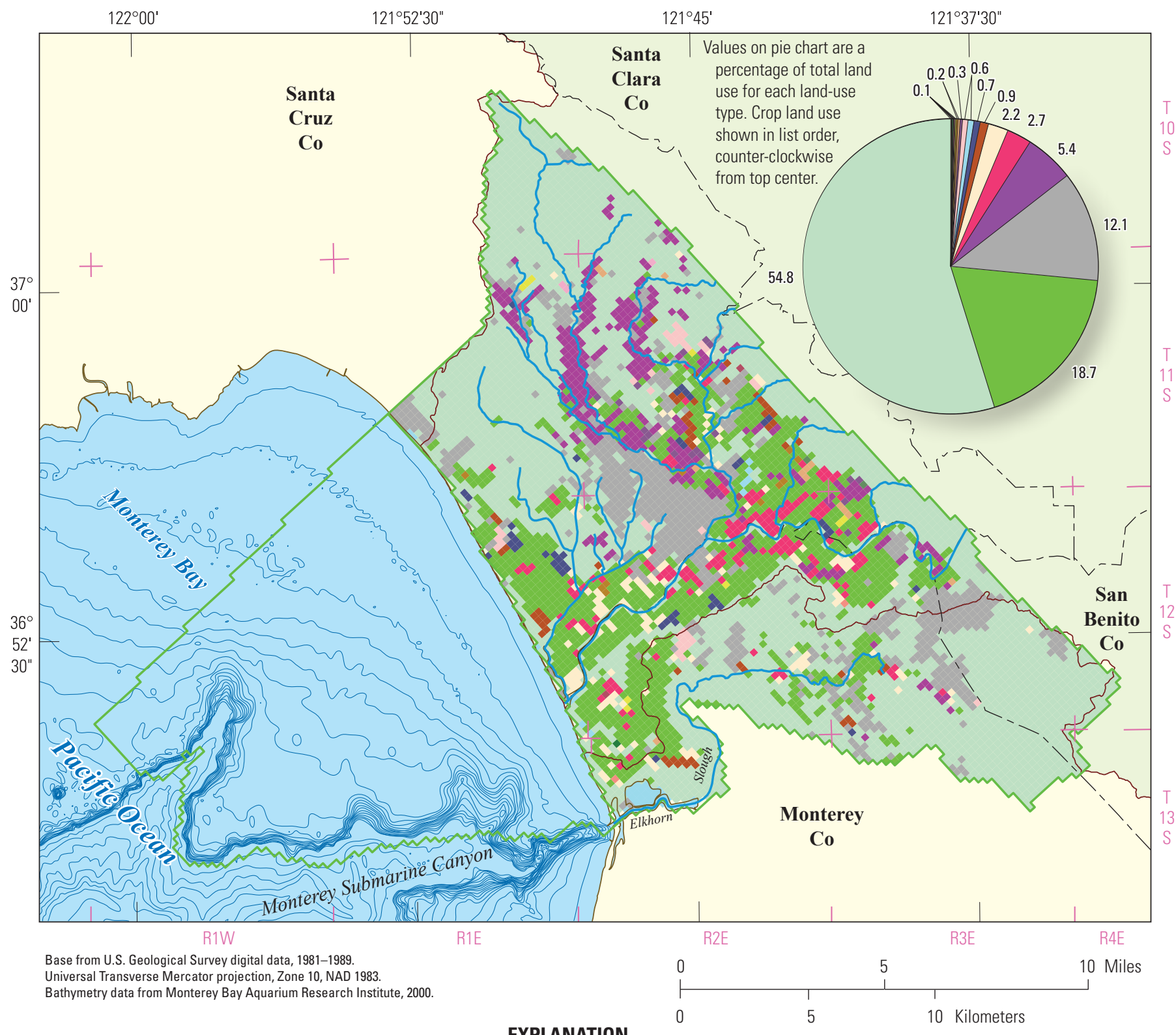

EXPLANATION

Model cell crop land use, 1991 (Modified from U.S. Geological Survey, 1999; California Department of Water Resources, 2000; Gilliom and others, 2006)
Pajaro River
Outside Pajaro River watershed

Native vegetation/riparian
Vegetable row crops (truck crops)
Turf (urban)
Deciduous (orchards)
Strawberry
Fallow
Pasture
Grains (field crops)
Water

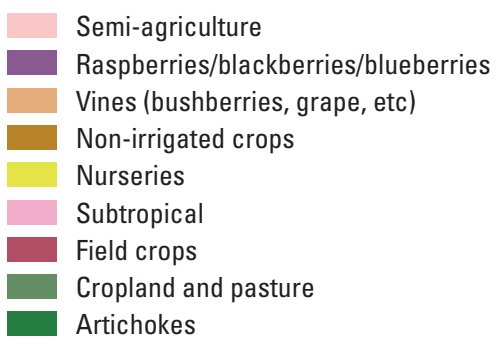

Irrigated row and field crops

Figure 14. Land-use (virtual crop) groups discretized to model grid for 1991, and pie chart of percentage of total land use over entire model area, Pajaro Valley, California. 
urban cells, the maps were updated to the 1997 land use. Finally, where only irrigated row and field crops were specified, the crops were updated based on data from the 2000 land use map. In this amalgamated 1993 map, approximately 43 percent of the valley was covered by native vegetation, 42 percent was agricultural land (of this 42 percent, 63 percent was cropland and pasture and 6 percent was orchards and vineyards), 15 percent was urban land (fig. 15).

For the 1997 land-use map, data were obtained from CADWR land-use maps for Monterey, Santa Cruz, and San Benito counties for 1997 (California Department of Water Resources, 1997; fig. 16). The county land use survey data were developed by CADWR through its Division of Planning and Local Assistance from aerial photography and extensive field surveys. The land use survey gathered detailed information on agricultural land uses, but less detailed information on urban and native vegetation land uses. The agricultural classifications can be correlated to the CADWR 12 class- 1 categories (California Department of Water Resources, 2000). This level of spatial detail is adequate for the current study. The CADWR prepares detailed county maps of the agricultural land use on the valley floor every 6-7 years, which may not represent the cropping patterns involving seasonal or annual rotations that have become more widespread in recent years. Hence, the 1997 virtual crop map represents a composite map for land use from the early to mid-1990s and this type of map still lacks the temporal detail needed to accurately reflect the effects of short crop rotation schedules. Although the data are suitable for representing regional spatial patterns of land use and crop patterns, there are potential discrepancies across county boundaries. The agricultural classes were kept at the class level as opposed to the more detailed crops that were identified. The agricultural land was grouped into 14 classes of use. The upland areas were missing and were classified as native vegetation. Approximately 49 percent of the valley was covered by native vegetation, 32 percent was agricultural land, and 18 percent was urban land use (fig. 16). The largest agricultural land use, which was all irrigated, was strawberries, 8 percent, and vegetable row crops (truck crops), 11 percent.
For the 2000 land-use map, data were obtained in digital format (California Department of Water Resources, 2000; fig. 17). These data are of a similar type, source, and quality as that for the 1997 land use map. Approximately 49 percent of the valley was covered by native vegetation, 33 percent was agricultural land, and 17 percent was urban land (fig. 17). As might be expected, the spatial distribution is similar to that of 1997, with only small local changes.

For the 2006 land-use map, data were obtained in digital format from the Pajaro Valley Water Management Agency (Jonathan Lear, written commun., 2007; fig. 18). These data were based on parcel maps for Santa Cruz County and show more detailed distributions of the crops than the CADWR land use maps (California Department of Water Resources, 2000). These data, however, do not cover the entire valley and were supplemented with the CADWR land use maps (California Department of Water Resources, 2000) where they did not exist. Approximately 48 percent of the valley was covered by native vegetation, 35 percent was agricultural land, and 17 percent was urban land (fig. 18). As might be expected, the spatial distribution is similar to that of 1997 and 2000, with only small local changes. The actual land use (fig. 18A) and the model discretized land use (fig. 18B) are shown for this most detailed land-use cover to demonstrate the alignment of actual and modeled land use over the active model area.

For the final year of the modeled period, the 2009 landuse classification was used for crop and land-use distributions (fig. 18C). The 2009 data were updates of the 2006 land use based on field checks made during pumpage meter readings in June 2009 (Pajaro Valley Water Management Agency, written commun., 2010).

Overall, the changes in total land use from 1970 to 2009 include a small decrease for natural vegetation, a small increase in percentage of urban land use, and multiple changes in agricultural land use. Changes in agricultural land use are towards more efficiently grown crops and a decline in vegetable row crops from 12 to 9 percent of the land use, a decline in orchards crops in recent years from about 7 to 3.5 percent of total land use, and an increase in the strawberry, vine crops and other berries, and nursery land use (fig. 18D). The area of nonirrigated agriculture also shows some temporary increases, but a net decrease by 2006 (fig. 18D). 


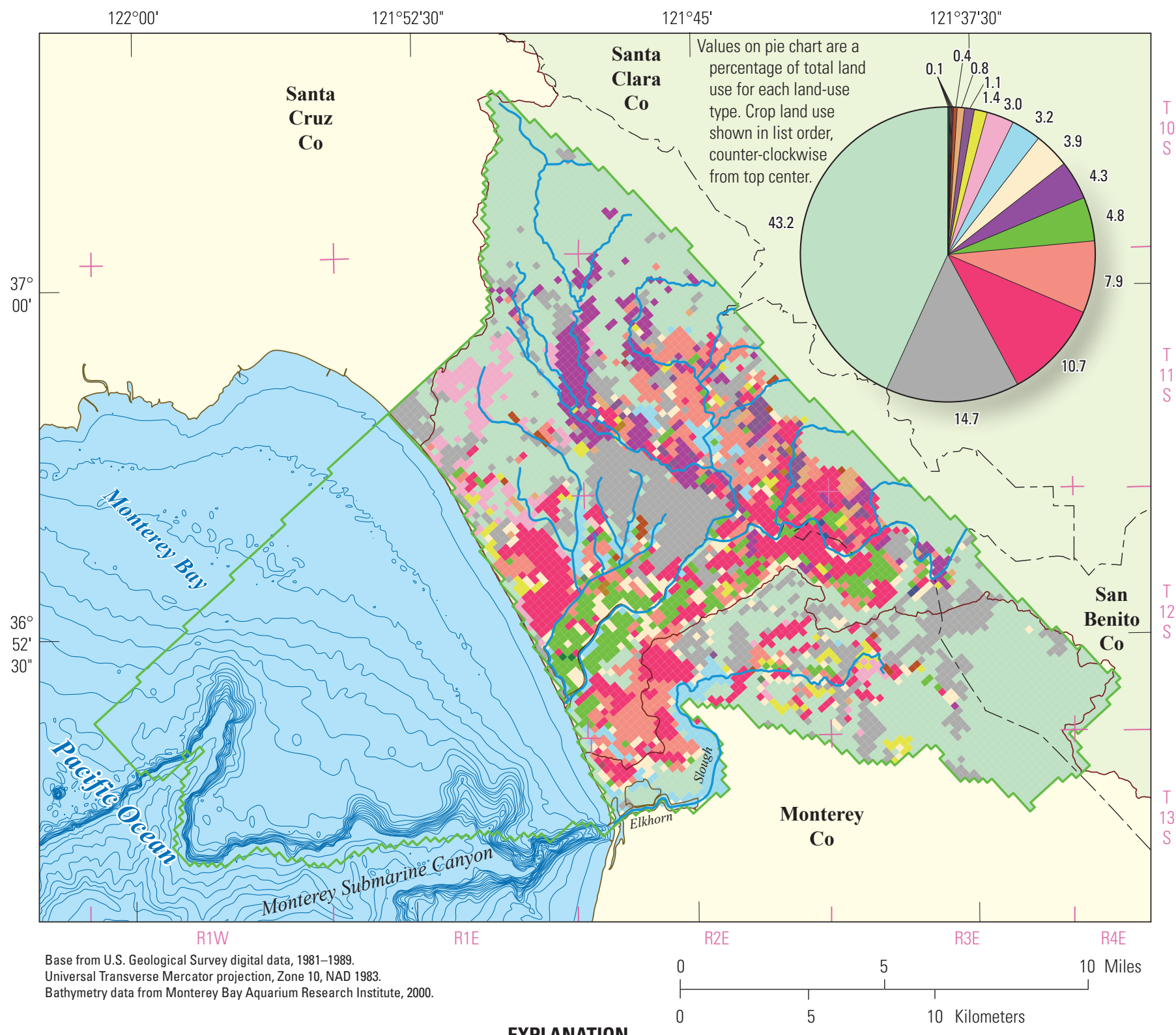

EXPLANATION

Model cell crop land use, 1993 (Modified from Geiben, 1998)

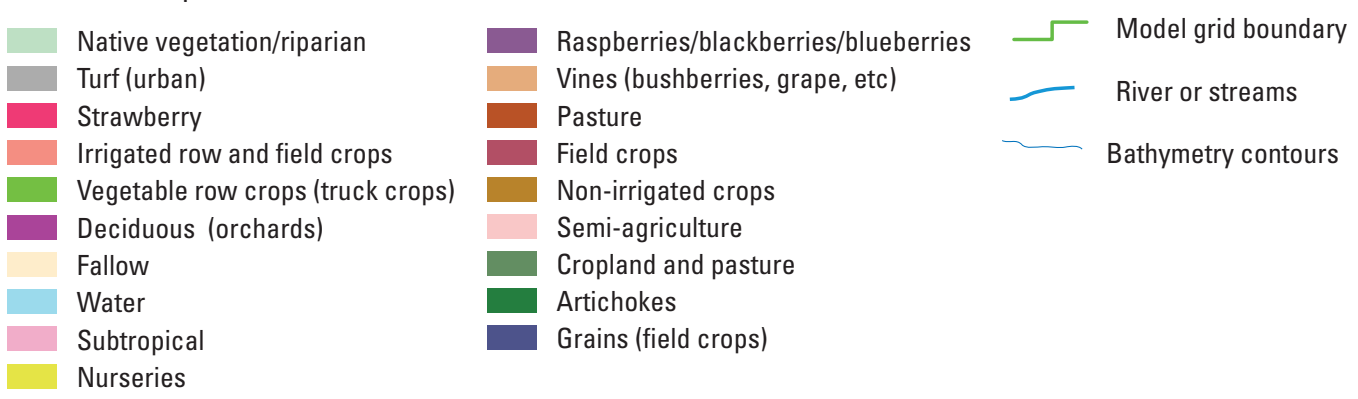

Figure 15. Land-use (virtual crop) groups discretized to model grid for 1993, and pie chart of percentage of total land use over entire model area, Pajaro Valley, California. 


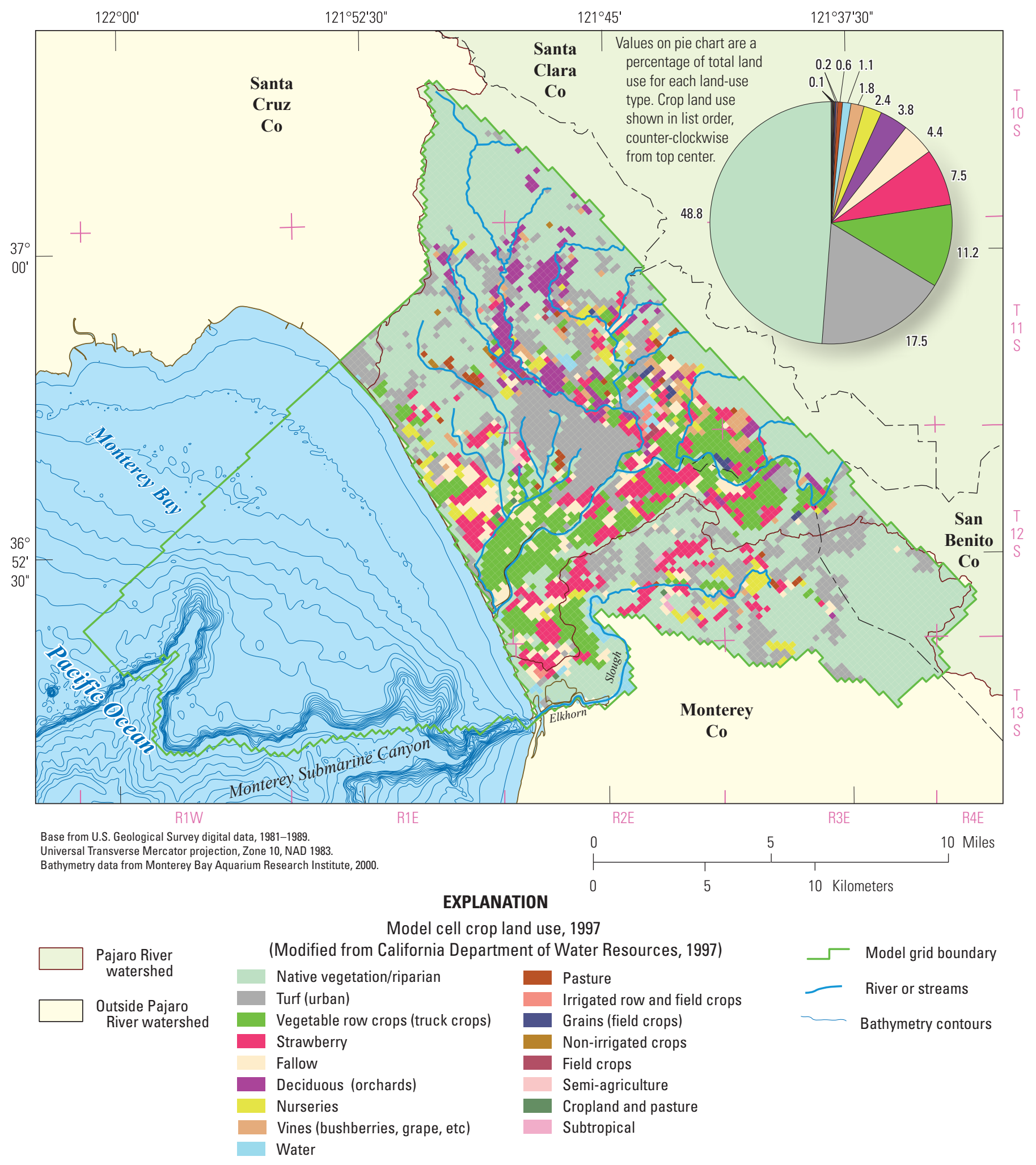

Figure 16. Land-use (virtual crop) groups discretized to model grid for 1997, and pie chart of percentage of total land use over entire model area, Pajaro Valley, California. 


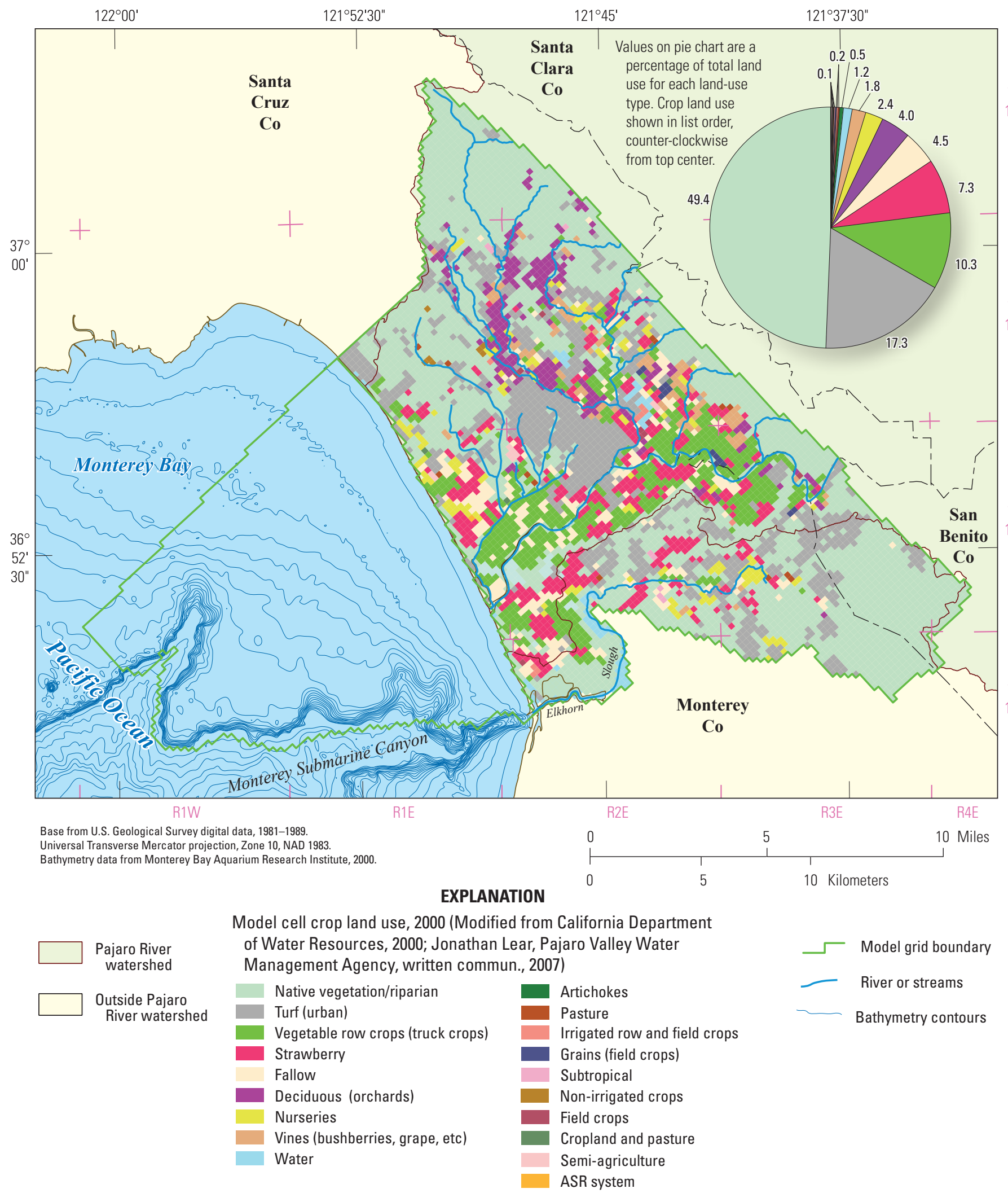

Figure 17. Land-use (virtual crop) groups discretized to model grid for 2000, and pie chart of percentage of total land use over entire model area, Pajaro Valley, California. [ASR, aquifer-storage-and-recovery] 


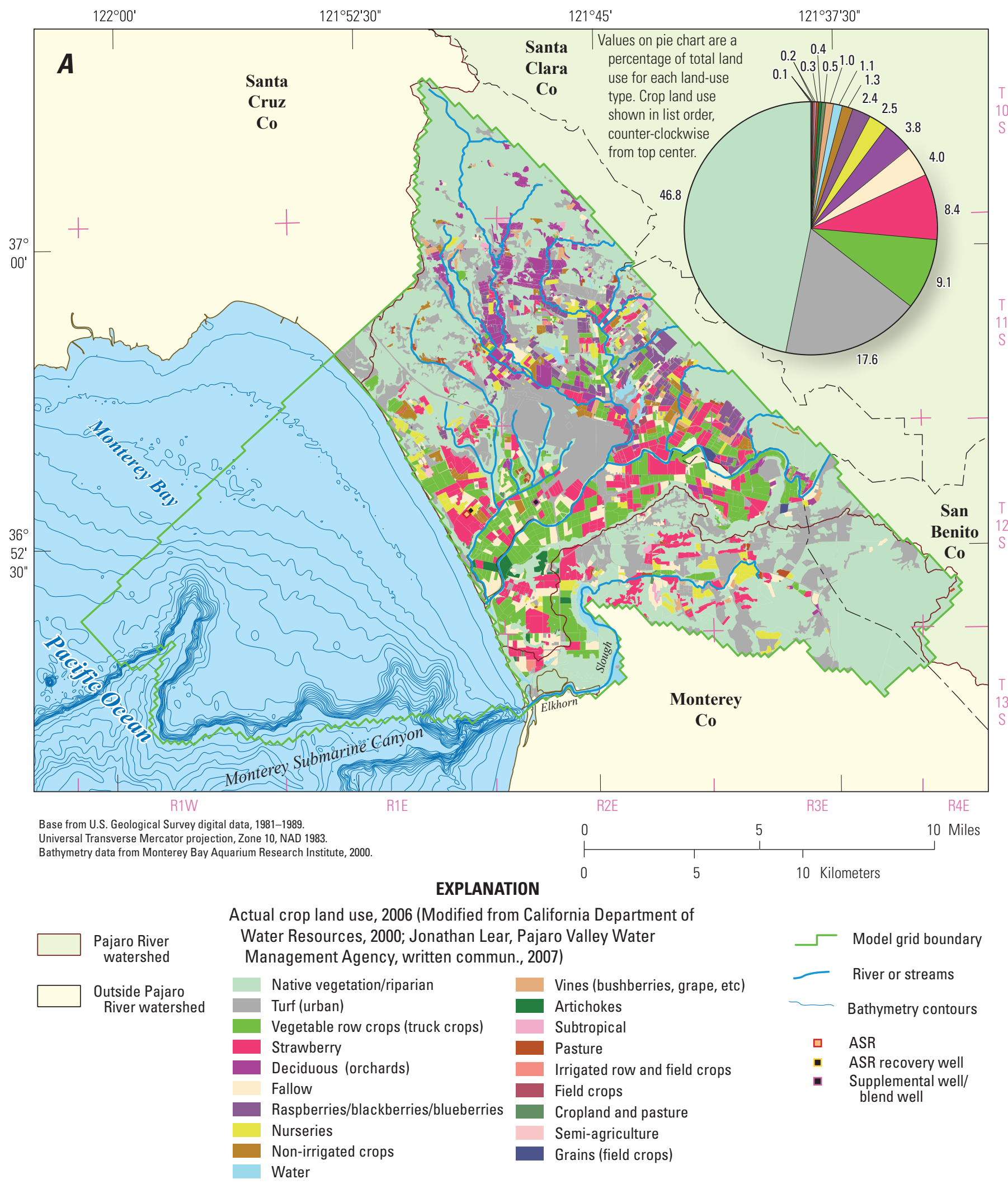

Figure 18. A, actual major categories of land-use for 2006; $B, 2006$ model equivalent land-use (virtual crop) groups discretized to model grid, and pie chart of percentage of total land use over entire model area; $C, 2009$ model equivalent land-use (virtual crop) groups discretized to model grid, and pie chart of percentage of total land use over entire model area; and $D$, changes in percentages of selected land use through time (2000-09), Pajaro Valley, California. [ASR, aquifer-storage-and-recovery] 


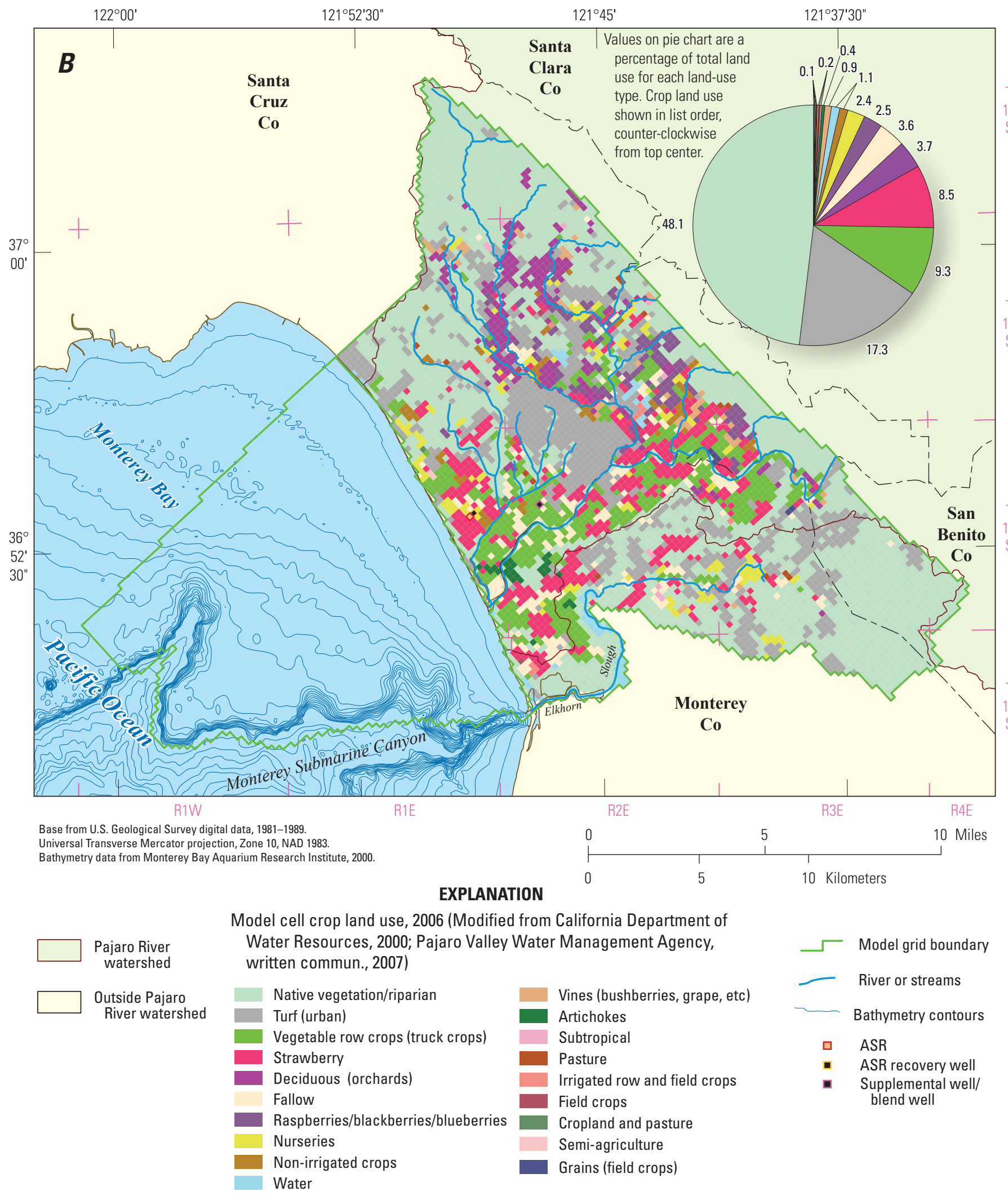

Figure 18. - Continued 


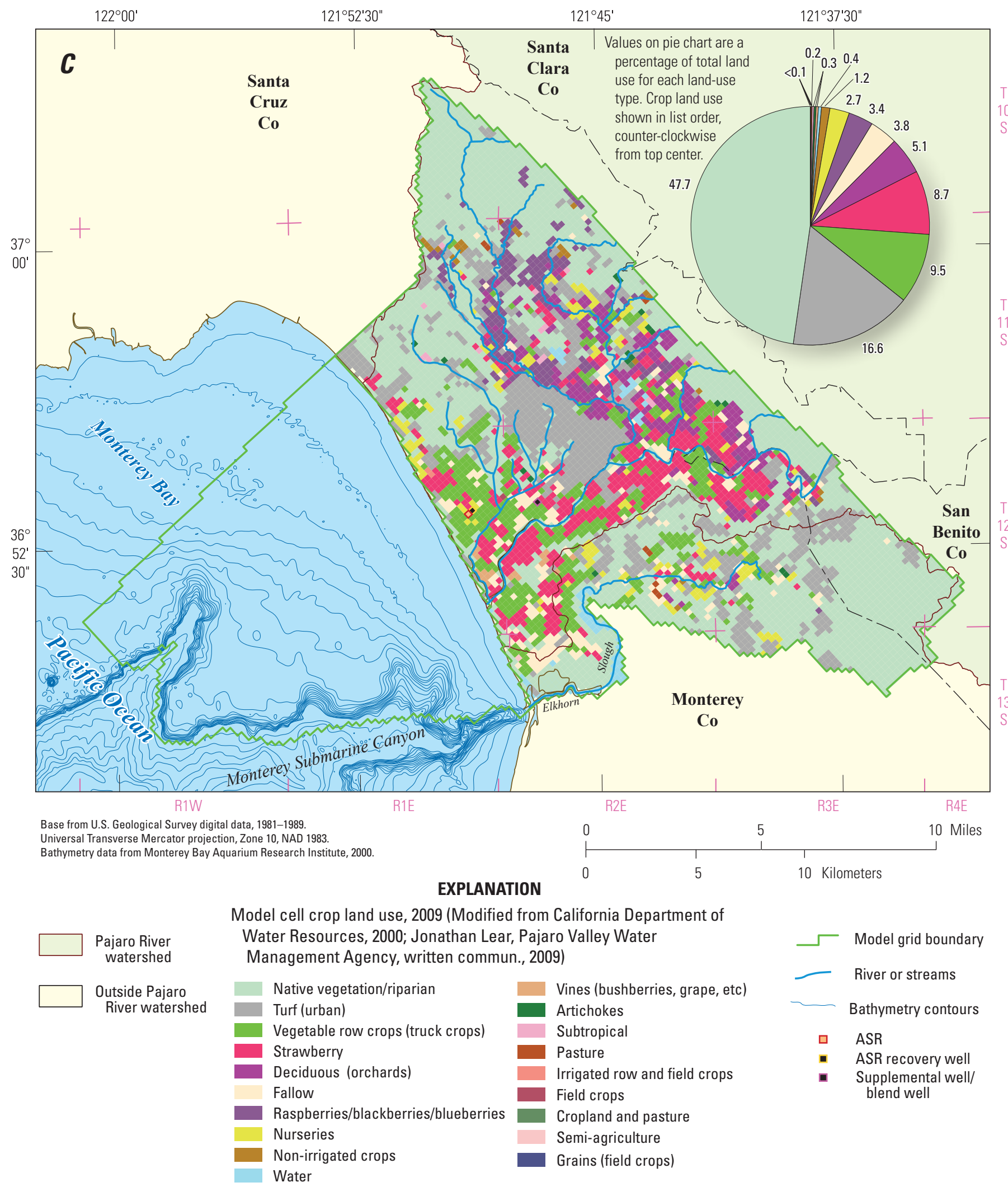

Figure 18. - Continued 


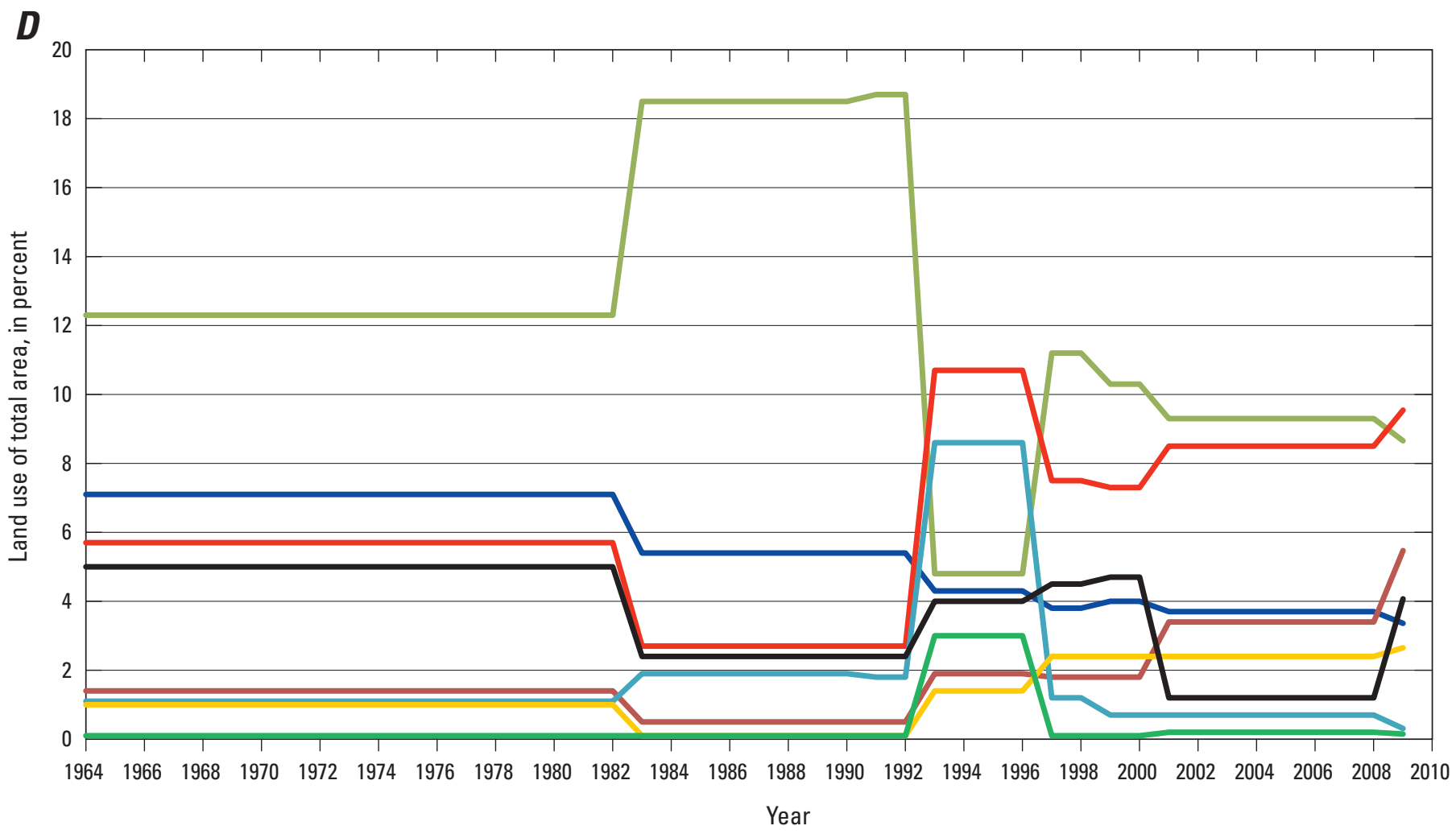

EXPLANATION

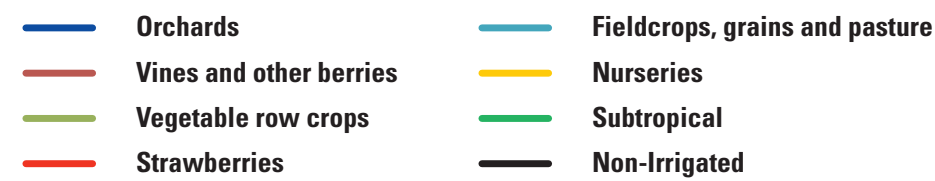

Figure 18. - Continued

\section{Crop-Type Data}

The virtual crops provide a basis for estimating the consumptive use of water at the land surface, a key component of the TFDR (Schmid and others, 2006a). The TFDR is largely determined by the crop irrigation requirement (CIR). The CIR is determined on a cell-by-cell basis from the product of a $\mathrm{ET}_{\mathrm{h}}$ and an area-weighted crop coefficient $\left(\mathrm{K}_{\mathrm{c}}\right)$; these products are summed over all cells within each WBS. Because so many factors affect ET (including weather parameters, soil factors, and plant factors), it is difficult to formulate an equation that can produce estimates of ET under different sets of conditions (California Department of Water Resources, 2007). Therefore, the idea of a reference crop ET was developed (California Department of Water Resources, 2007). The reference ET from a standardized (evenly mowed) grass surface is commonly denoted either as ETo or $\mathrm{ET}_{\mathrm{h}}$ (the latter form is used in this report).
Specified root depths, suction pressures for the unsaturated root zone, crop coefficients, and fractions of transpiration and evaporation affect the consumption and movement of water for each crop category. For the PVHM, the root depths and root uptake pressures were held constant for the entire simulation and are based on values from the literature (table 7; Schmid and others, 2006a). Suction pressures in the root zone can range from positive (hydrostatic) for water-saturated settings including the ASR system and riparian vegetation in wetlands, to negative (unsaturated) pressure for agriculture and native vegetation such as grasses, shrubs, and trees.

Direct Transpiration (T) and Evaporation (E) from the groundwater occurs for a rising water table when the top of the capillary fringe above the water table reaches the bottom of the root zone of plants and when the top of the capillary fringe above the water table reaches the land surface, 
Table 7. Summary of Pajaro Valley virtual crop categories and properties, the Pajaro Valley hydrologic model (PVHM), Pajaro Valley, California.

[FMP2, updated version of the Farm Process; - , no data]

\begin{tabular}{|c|c|c|c|c|c|c|c|}
\hline \multirow{3}{*}{$\begin{array}{c}\begin{array}{c}\text { FMP2 } \\
\text { crop index number } \\
\text { and virtual-crop } \\
\text { crop category }\end{array} \\
\text { 1. Vegetable row crops (truck crops) }{ }^{2}\end{array}$} & \multirow{3}{*}{$\begin{array}{c}\begin{array}{c}\text { Maximum } \\
\text { root } \\
\text { depth } \\
\text { (feet) }\end{array} \\
1.51\end{array}$} & \multicolumn{4}{|c|}{$\begin{array}{c}\text { Root uptake pressure heads } \\
\text { (feet) }\end{array}$} & \multirow{2}{*}{\multicolumn{2}{|c|}{$\begin{array}{l}\text { Fraction of surface-water } \\
\text { runoff from precipitation } \\
\text { (left) and irrigation (right) } \\
\text { (dimensionless) }\end{array}$}} \\
\hline & & \multirow{2}{*}{$\begin{array}{c}\text { Anoxia } \\
-0.49\end{array}$} & \multirow{2}{*}{$\begin{array}{c}\begin{array}{c}\text { Lower optimal } \\
\text { range }\end{array} \\
-0.98\end{array}$} & \multirow{2}{*}{$\begin{array}{c}\begin{array}{c}\text { Upper optimal } \\
\text { range }\end{array} \\
-17.88\end{array}$} & \multirow{2}{*}{$\begin{array}{l}\text { Wilting } \\
-262.48\end{array}$} & & \\
\hline & & & & & & 0.99 & 0.99 \\
\hline 2. Strawberries & 3.00 & -0.49 & -0.98 & -17.88 & -262.48 & 0.03 & 0.01 \\
\hline 3. Artificial storage and recovery site & 0.33 & 0.00 & 0.00 & 0.00 & 0.00 & 0.00 & 0.00 \\
\hline 5. Field crops ${ }^{2}$ & 3.98 & -0.49 & -0.98 & -98.43 & -405.86 & 0.60 & 0.40 \\
\hline 6. Deciduous trees (orchards) ${ }^{2}$ & 6.00 & -0.43 & -0.89 & -22.77 & -377.32 & 0.60 & 0.40 \\
\hline 7. Subtropical crops $^{2}$ & 4.00 & -0.49 & -0.98 & -19.69 & -262.48 & 0.60 & 0.40 \\
\hline 8. Vines (bushberries, grape, etc) ${ }^{2}$ & 4.99 & -0.49 & -0.98 & -23.79 & -262.48 & 0.70 & 0.02 \\
\hline 12. Native vegetation / riparian $^{3}$ & 49.21 & 0.00 & 0.00 & -27.07 & -377.32 & 0.945 & - \\
\hline 13. Water & 3.61 & 1.64 & 0.33 & -0.98 & -1.31 & 0.9 & - \\
\hline 14. Nurseries & 3.00 & -0.49 & -0.98 & -17.88 & -262.48 & 0.99 & 0.35 \\
\hline 15. Cropland and pasture ${ }^{3}$ & 4.92 & 0.00 & 0.00 & -37.40 & -262.48 & 0.60 & 0.40 \\
\hline 16. Raspberries / blackberries / blueberries ${ }^{2}$ & 6.27 & -0.49 & -0.98 & -17.88 & -262.48 & 0.90 & 0.02 \\
\hline 17. Irrigated row and field crops $^{3}$ & 3.98 & -0.43 & -0.92 & -37.40 & -262.48 & 0.60 & 0.40 \\
\hline 18. Semi-agriculture ${ }^{3}$ & 3.28 & -0.25 & -0.66 & -27.07 & -377.32 & 0.70 & 0.50 \\
\hline 19. Fallow & 5.28 & 0.00 & 0.00 & -27.07 & -377.32 & 0.70 & - \\
\hline 20. Non-irrigated crops ${ }^{3}$ & 4.92 & 0.00 & 0.00 & -17.88 & -262.48 & 0.70 & - \\
\hline
\end{tabular}

${ }^{1}$ For additional information on FMP parameters please refer to Schmid and others (2006a) and Schmid and Hanson (2009).

${ }^{2}$ Area-weighted crop groups.

${ }^{3}$ Undifferentiated crop groups based on generalized land-use map categories.

respectively. For a declining water table, the direct $\mathrm{T}$ and $\mathrm{E}$ from groundwater are eliminated when the top of the capillary fringe above the water table falls below the bottom of the root zone and when the top of the capillary fringe above the water table falls below the land surface (Schmid and others, 2006a).

Crop water demand can be related to the crop growth stages by the product of the $\mathrm{K}_{\mathrm{c}}$ values and a crop stress coefficient. The $\mathrm{K}_{c}$ values used in this study were based on an unstressed crop growth curve. This growth curve was divided into twelve monthly stages spanning the initial growth stage, the rapid growth stage, the mid-season stage, the late-season stage, and a period of no planting (fig. 19). Although the specific growth dates for each virtual crop vary depending on the planting date and climatic zone, growth dates are assumed to be spatially uniform throughout the valley. The only change in $\mathrm{K}_{\mathrm{c}}$ value at a location is based on a change in virtual crop with land-use changes and the crop stress coefficient for different wet- and dry-year seasons.
The $\mathrm{K}$ values (figs. 19A-D) were derived from several sources. When available, published $\mathrm{K}_{c}$ values for similar coastal areas were used (Allen and others, 1998; Snyder and others, 1987a, b; Brouwer and others, 1985; Brouwer and Heibloem, 1986). When no published $\mathrm{K}_{\mathrm{c}}$ values for coastal areas were available, published $\mathrm{K}_{\mathrm{c}}$ values for the western San Joaquin Valley compiled by Brush and others (2004) were used. Additional specific crop coefficients were used for greenhouse crops (Orgaz and others, 2005), turfgrass (Gibeault and others, 1989), and strawberries (Hanson and Bendixen, 2004; Snyder and Schullbach, 1992). In many cases, multiple crops were area weighted to produce a composite virtual $\mathrm{K}_{\mathrm{c}}$ value. For example, the virtual crop "deciduous" is largely composed of apples, with some minor acreage of walnuts, pears, olives, avocados, and other miscellaneous deciduous trees. The $\mathrm{K}_{\mathrm{c}}$ values were divided into two periods of agriculture representing an early period of more traditional seasonal agriculture in the Pajaro Valley from 1963-92 and a 
$\boldsymbol{A}$

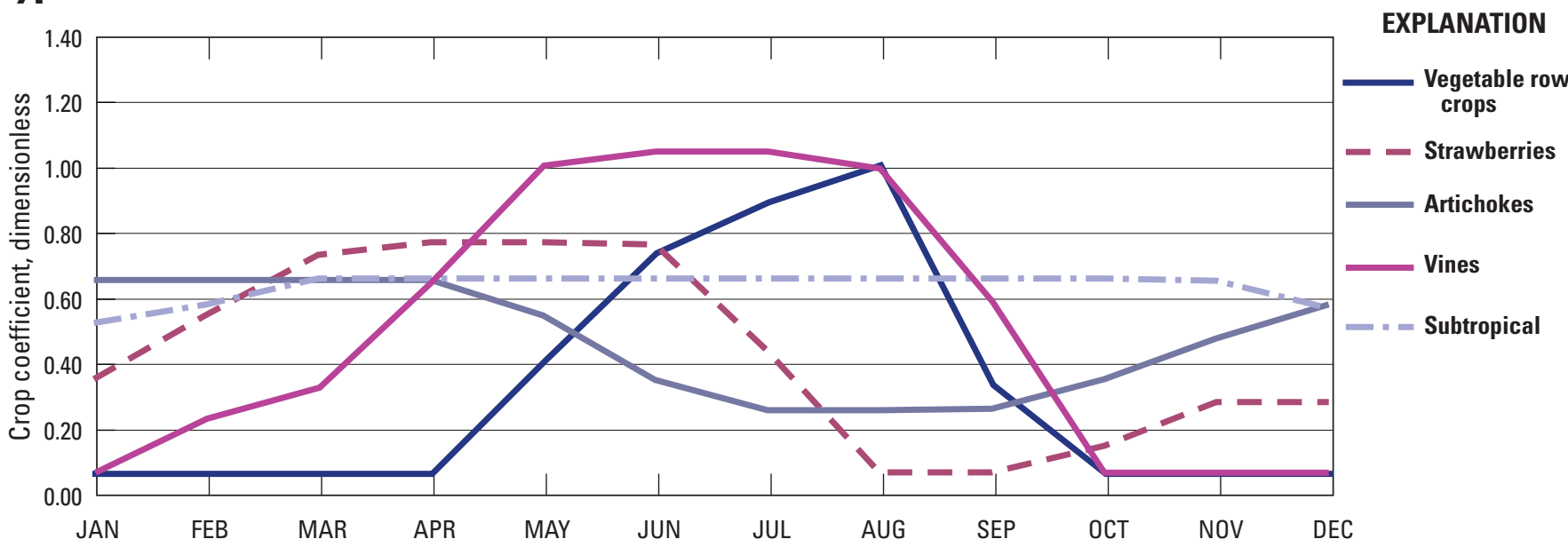

B

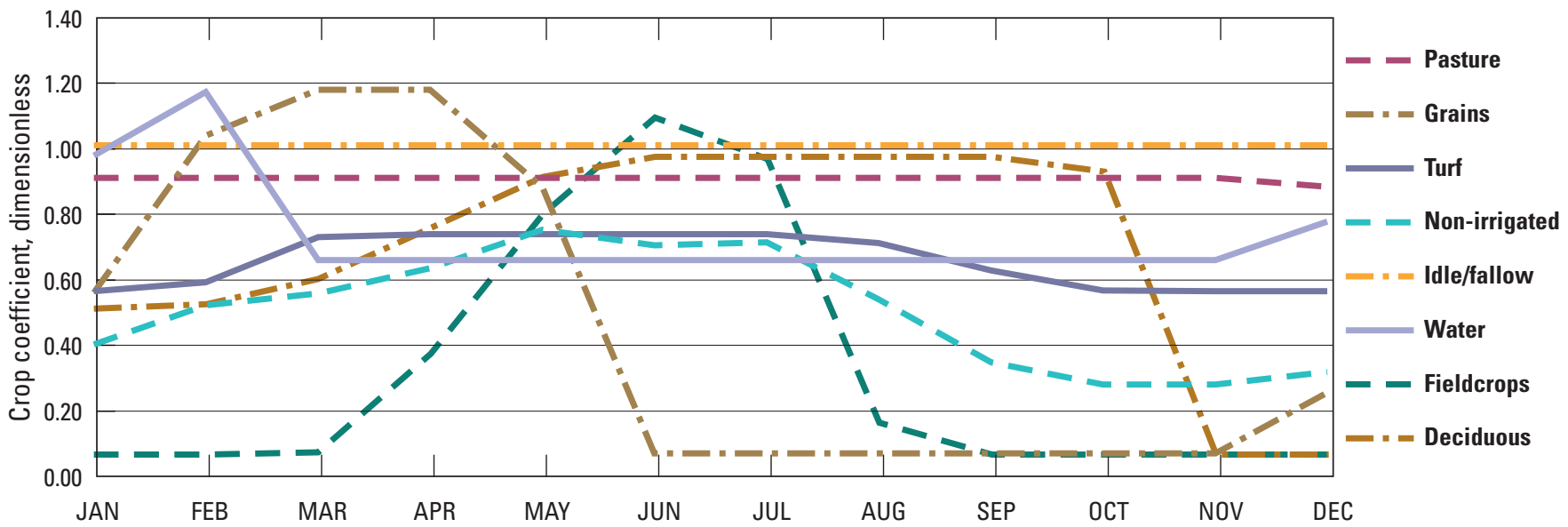

C

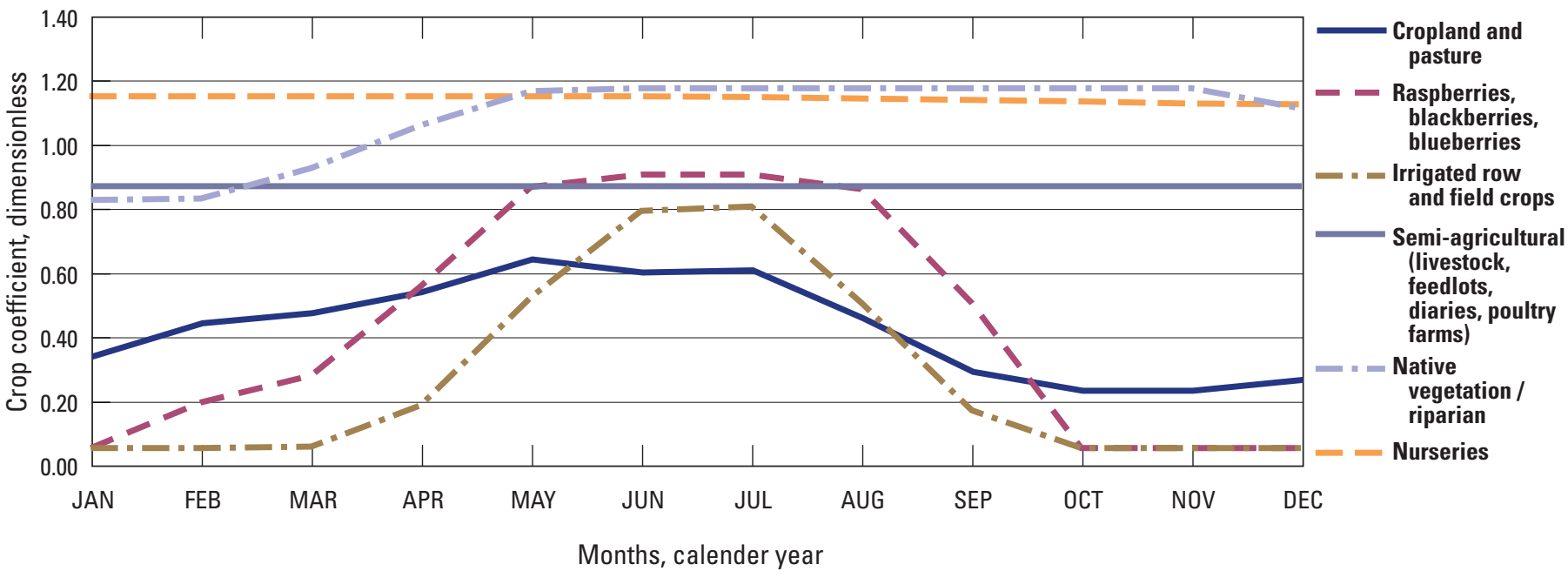

Figure 19. Monthly crop coefficients for $A$, fruits and vegetables; $B$, grains and turf, $C$, native and pasture; and $D$, crops with modified growth or double crops in the Pajaro Valley, California. 
D
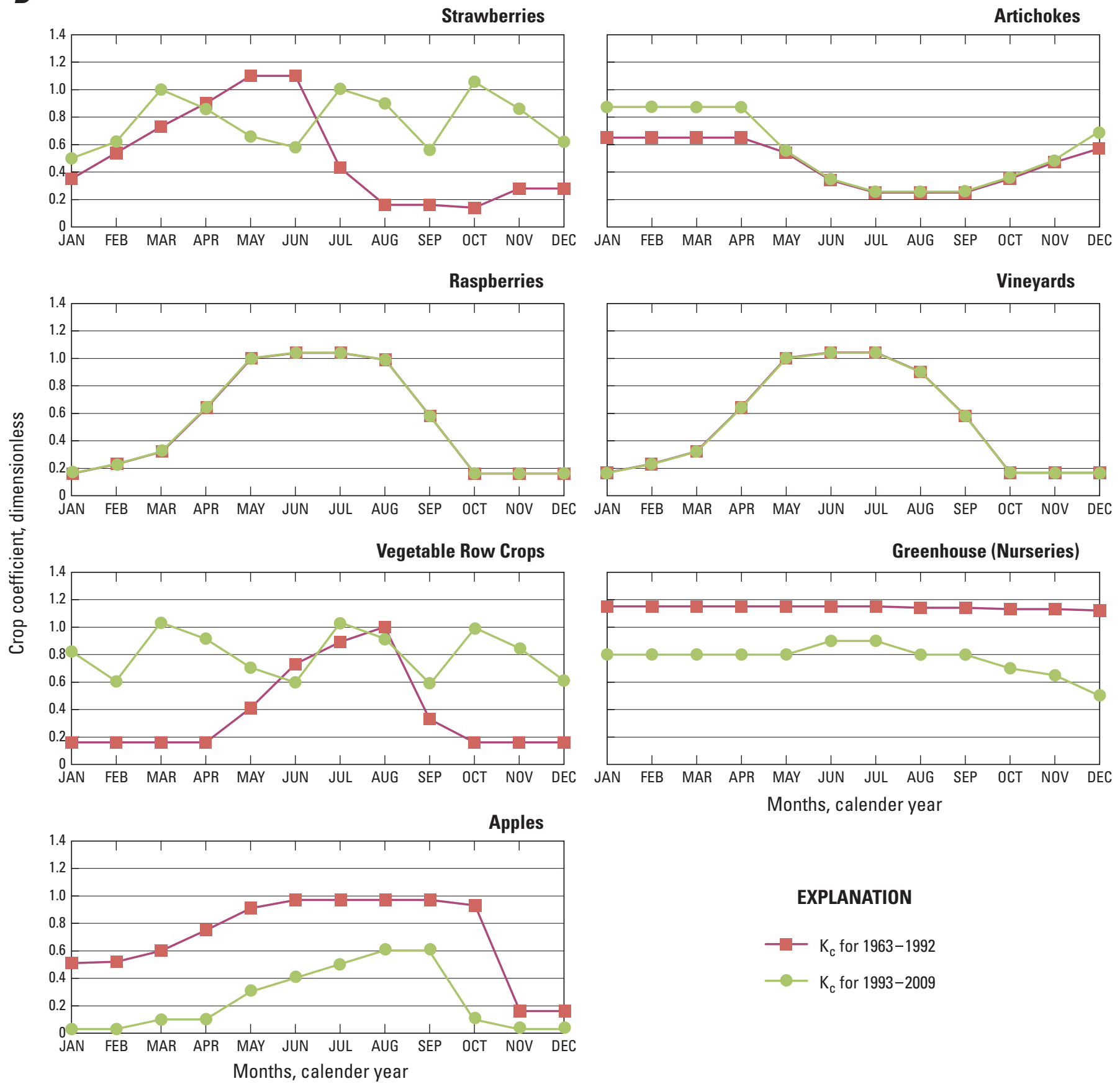

Figure 19. -Continued

more recent period of more intensified agriculture from 19932006. The transition between these periods of agriculture was placed at the end of the last multi-year drought (1984-92). The $\mathrm{K}_{\mathrm{c}}$ values for the one model cell (Virtual crop 3 and WBS 14) that represents the ASR system near Harkins Slough were further modified for the months of January through May to create the demand needed to deliver water from the HS-ASR system The increases in monthly $\mathrm{K}_{\mathrm{c}}$ values are a function of a reported infiltration rate of about 16 acre-ft per day and an assumed efficiency of about 50 percent. The monthly $\mathrm{ET}_{\mathrm{h}}$ at this ASR system model cell was used with these data to estimate the increased $\mathrm{K}_{\mathrm{c}}$ value needed to create the demand for the delivery at the potential infiltration rate. Note that the potential simulated demand is constrained by the potential simulated supply represented by the amount of water actually diverted at the Harkins Slough each month. 
Finally, the $\mathrm{K}$ values were multiplied by a crop-stress coefficient (Schmid and Hanson, 2009), the values of which depended on climatic conditions and other factors. The climatic stress on irrigated agriculture can vary by more than 20 percent between wet and dry seasons (Hanson and others, 2010). Eight stress coefficients were used that represent the wet- and dry-year seasons. These stress coefficients were adjusted during model calibration.

Other WBS and crop-related properties that were specified include the fraction of total ET that is transpiration $\left(\mathrm{F}_{\mathrm{tr}}\right)$, fraction of evaporation from precipitation $\left(\mathrm{F}_{\mathrm{ep}}\right)$, fraction of evaporation from irrigation ( $\mathrm{F}_{\mathrm{ei}}$; dimensionless), and the irrigation efficiencies. These fractions vary linearly with the respective area occupied by crops and the area with no crop canopy that is open to soil-evaporation (Schmid and others, 2006a). Because the crop canopy area and the exposed soil area sum to the entire area, $\mathrm{F}_{\mathrm{tr}}$ plus $\mathrm{F}_{\mathrm{ep}}$ equals one. In addition, $\mathrm{F}_{\mathrm{ei}}$ must be less than or equal to $\mathrm{F}_{\mathrm{ep}}$, because transpiration from crop canopy areas inherently reduces the evaporative fraction in canopy areas. The $\mathrm{F}_{\mathrm{tr}}$ is assumed to be independent of whether the transpiratory consumptive use is satisfied by irrigation, precipitation, or groundwater uptake. The fraction of the consumptive use that is transpiratory $\left(\mathrm{F}_{\mathrm{tr}}\right)$ or evaporative $\left(\mathrm{F}_{\mathrm{ep}}\right.$ and $\left.\mathrm{F}_{\mathrm{ei}}\right)$ depends highly on type of crop and growth stage. When the vegetation cover reaches nearly 100 percent, then $\mathrm{F}_{\mathrm{tr}}=1$ while $\mathrm{F}_{\mathrm{ep}}$ and $\mathrm{F}_{\mathrm{ei}}=0$. As a result, the fractions of transpiration and evaporation vary by virtual crop for different months of the year (table 8). These values are derived from the literature and from related studies (Faunt and others, 2009a; Schmid and others, 2006a).

Table 8. Summary of fractions of transpiration and evaporation by month for Pajaro Valley crop categories (virtual crops).

[FMP2, an updated version of the Farm Process, $\mathrm{F}_{\mathrm{tr}}$, fraction of transpiration; $\mathrm{F}_{\mathrm{ep}}$, fraction of evaporation from precipitation; $\mathrm{F}_{\mathrm{e} i}$, fraction of evaporation from irrigation]

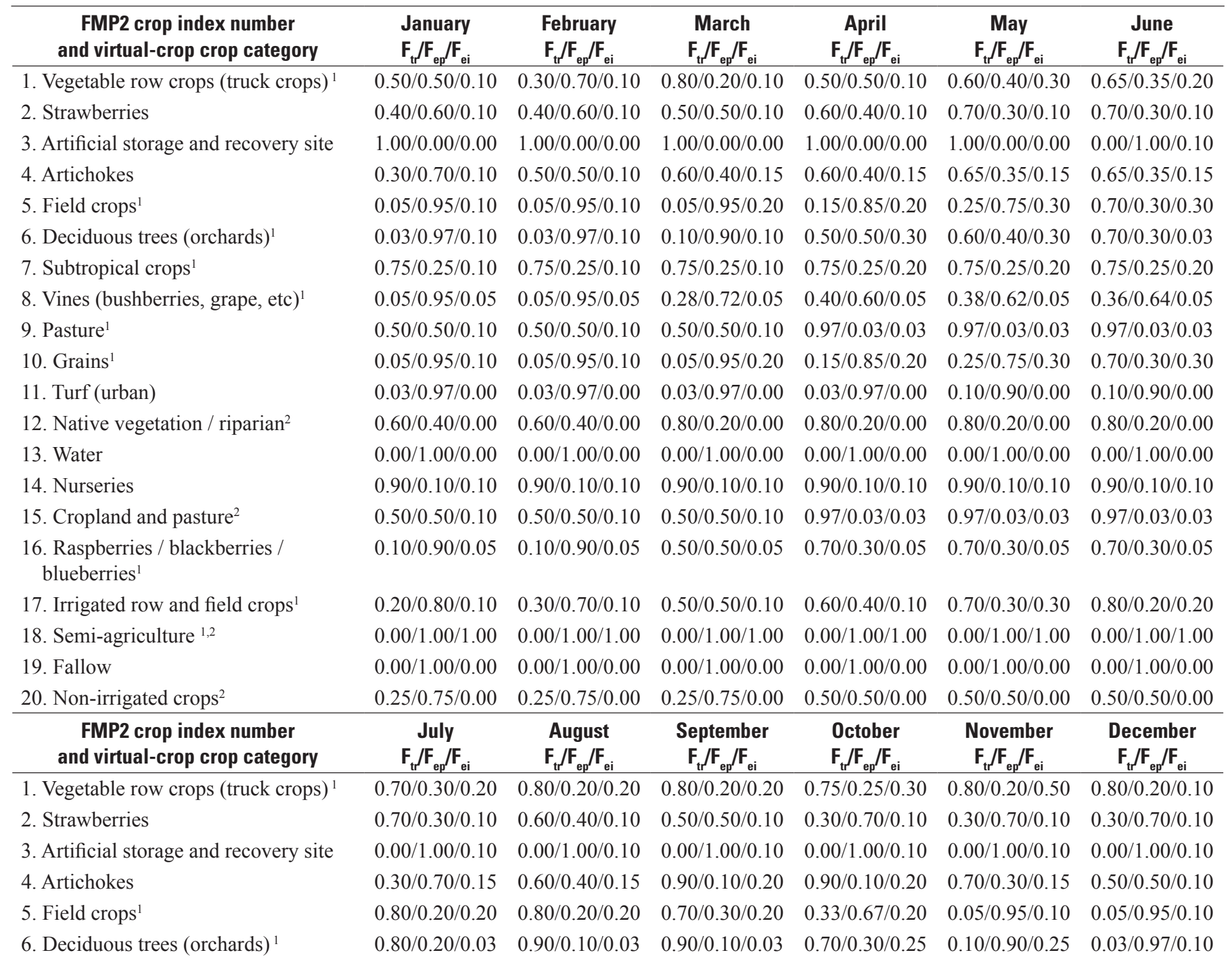


Table 8. Summary of fractions of transpiration and evaporation by month for Pajaro Valley crop categories (virtual crops).-Continued

[FMP2, an updated version of the Farm Process, $\mathrm{F}_{\mathrm{tr}}$, fraction of transpiration; $\mathrm{F}_{\mathrm{ep}}$, fraction of evaporation from precipitation; $\mathrm{F}_{\mathrm{e}}$, fraction of evaporation from irrigation]

\begin{tabular}{|c|c|c|c|c|c|c|}
\hline $\begin{array}{l}\text { FMP2 crop index number } \\
\text { and virtual-crop crop category }\end{array}$ & $\begin{array}{l}\text { January } \\
\mathrm{F}_{\mathrm{t}} / \mathrm{F}_{\mathrm{ep}} / \mathrm{F}_{\mathrm{ei}}\end{array}$ & $\begin{array}{l}\text { February } \\
F_{t} / F_{e p} / F_{e i}\end{array}$ & $\begin{array}{c}\text { March } \\
\mathrm{F}_{\mathrm{t} /} / \mathrm{F}_{\mathrm{ep}} / \mathrm{F}_{\mathrm{ei}}\end{array}$ & $\begin{array}{c}\text { April } \\
\mathrm{F}_{\mathrm{t}} / \mathrm{F}_{\mathrm{ep}} / \mathrm{F}_{\mathrm{ei}}\end{array}$ & $\begin{array}{c}\text { May } \\
\mathrm{F}_{\mathrm{t} /} / \mathrm{F}_{\mathrm{ep}} / \mathrm{F}_{\mathrm{ei}}\end{array}$ & $\begin{array}{c}\text { June } \\
\mathrm{F}_{\mathrm{t}} / \mathrm{F}_{\mathrm{ep}} / \mathrm{F}_{\mathrm{ei}}\end{array}$ \\
\hline 7. Subtropical crops ${ }^{1}$ & $0.75 / 0.25 / 0.20$ & $0.75 / 0.25 / 0.20$ & $0.75 / 0.25 / 0.20$ & $0.75 / 0.25 / 0.20$ & $0.75 / 0.25 / 0.10$ & $0.75 / 0.25 / 0.10$ \\
\hline 8. Vines (bushberries, grape, etc) ${ }^{1}$ & $0.36 / 0.64 / 0.05$ & $0.36 / 0.64 / 0.05$ & $0.36 / 0.64 / 0.05$ & $0.36 / 0.64 / 0.05$ & $0.20 / 0.80 / 0.05$ & $0.05 / 0.95 / 0.05$ \\
\hline 9. Pasture $^{2}$ & $0.96 / 0.04 / 0.04$ & $0.97 / 0.03 / 0.03$ & $0.97 / 0.03 / 0.03$ & $0.50 / 0.50 / 0.30$ & $0.50 / 0.50 / 0.10$ & $0.50 / 0.50 / 0.10$ \\
\hline 10. Grains ${ }^{2}$ & $0.80 / 0.20 / 0.20$ & $0.80 / 0.20 / 0.20$ & $0.70 / 0.30 / 0.20$ & $0.33 / 0.67 / 0.20$ & $0.05 / 0.95 / 0.10$ & $0.05 / 0.95 / 0.10$ \\
\hline 11. Turf (urban) & $0.10 / 0.90 / 0.00$ & $0.10 / 0.90 / 0.00$ & $0.70 / 0.30 / 0.20$ & $0.03 / 0.97 / 0.00$ & $0.03 / 0.97 / 0.00$ & $0.03 / 0.97 / 0.00$ \\
\hline 12. Native vegetation / riparian ${ }^{2}$ & $0.80 / 0.20 / 0.00$ & $0.80 / 0.20 / 0.00$ & $0.80 / 0.20 / 0.00$ & $0.80 / 0 . .2 / 0.00$ & $0.80 / 0.20 / 0.00$ & $0.60 / 0.40 / 0.00$ \\
\hline 13. Water & $0.00 / 1.00 / 0.00$ & $0.00 / 1.00 / 0.00$ & $0.00 / 1.00 / 0.00$ & $0.00 / 1.00 / 0.00$ & $0.00 / 1.00 / 0.00$ & $0.00 / 1.00 / 0.00$ \\
\hline 14. Nurseries & $0.90 / 0.10 / 0.10$ & $0.90 / 0.10 / 0.10$ & $0.90 / 0.10 / 0.10$ & $0.90 / 0.10 / 0.10$ & $0.90 / 0.10 / 0.10$ & $0.90 / 0.10 / 0.10$ \\
\hline 15. Cropland and pasture ${ }^{2}$ & $0.96 / 0.04 / 0.04$ & $0.97 / 0.03 / 0.03$ & $0.97 / 0.03 / 0.03$ & $0.50 / 0.50 / 0.30$ & $0.50 / 0.50 / 0.10$ & $0.50 / 0.50 / 0.10$ \\
\hline $\begin{array}{l}\text { 16. Raspberries / blackberries / } \\
\text { blueberries }^{1}\end{array}$ & $0.70 / 0.30 / 0.05$ & $0.70 / 0.30 / 0.05$ & $0.70 / 0.30 / 0.05$ & $0.70 / 0.30 / 0.05$ & $0.70 / 0.30 / 0.05$ & $0.10 / 0.90 / 0.05$ \\
\hline 17. Irrigated row and field crops ${ }^{2}$ & $0.80 / 0.20 / 0.20$ & $0.80 / 0.20 / 0.20$ & $0.80 / 0.20 / 0.20$ & $0.70 / 0.30 / 0.30$ & $0.50 / 0.50 / 0.50$ & $0.30 / 0.70 / 0.10$ \\
\hline 18. Semi-agriculture ${ }^{2}$ & $0.00 / 1.00 / 1.00$ & $0.00 / 1.00 / 1.00$ & $0.00 / 1.00 / 1.00$ & $0.00 / 1.00 / 1.00$ & $0.00 / 1.00 / 1.00$ & $0.00 / 1.00 / 1.00$ \\
\hline 19. Fallow & $0.00 / 1.00 / 0.00$ & $0.00 / 1.00 / 0.00$ & $0.00 / 1.00 / 0.00$ & $0.00 / 1.00 / 0.00$ & $0.00 / 1.00 / 0.00$ & $0.00 / 1.00 / 0.00$ \\
\hline 20. Non-irrigated crops ${ }^{2}$ & $0.50 / 0.50 / 0.00$ & $0.50 / 0.50 / 0.00$ & $0.50 / 0.50 / 0.00$ & $0.50 / 0.50 / 0.00$ & $0.25 / 0.75 / 0.00$ & $0.25 / 0.75 / 0.00$ \\
\hline
\end{tabular}

${ }^{1}$ Area weighted crop groups.

${ }^{2}$ Undifferentiated crop groups based on generalized land-use map categories.

The irrigation efficiencies are defined as the fraction of applied water actually consumed by plants (transpiration). Inefficiency in the conveyance and spreading of applied water results in losses to runoff and deep percolation, particularly as a result of excess irrigation and excess precipitation (Schmid and others, 2006a). In the PVHM, the irrigation efficiencies are specified as a matrix of efficiencies for each WBS and each crop for each of the monthly stress periods (Schmid and Hanson, 2009). In this way, the efficiencies vary from crop to crop for different WBSs and can change through time. The range in efficiency for each crop or crop group for each month in the simulation is tabulated in table 9. Irrigation efficiencies are assumed to have varied in time, reflecting improvements in irrigation application technologies, increased use of tail-water return systems and recycling of drainage water, and changes in the cost and availability of water (Brush and others, 2004). In general, the efficiencies have improved through time with technology advances in sprinkler systems and drip irrigation, and changes in cropping patterns (California Department of Water Resources, 1994). The increase in efficiency was taken into account during calibration with fractional irrigation efficiencies that were estimated to increase (table 9).

In general, irrigation efficiencies are poorly known (California Department of Water Resources, 1994; Brush and others, 2004) in early years of the model simulation period considered here, but likely improve for some crops in recent years owing to increasing use of efficient irrigation techniques such as drip irrigation. Because of the details incorporated in the FMP2, some part of what is typically lumped into the irrigation efficiency term in models (particularly uptake from the groundwater system) is now accounted for directly in the FMP2. Compared to previous simulations in the Pajaro Valley, the PVHM efficiencies specified in the FMP2 are typically more variable, with lower efficiencies in wet seasons and higher efficiencies in dry seasons. Irrigation efficiencies also may differ between wet-year and dry-year periods. Thus, irrigation efficiencies were also scaled on the basis of wet and dry-year seasons. These eight wet- and dry-year seasonal scale factors were adjusted during model calibration.

\section{Climate Data}

The consumptive use of water, specifically the TFDR, is directly related to climatic conditions. Although several of the properties specified previously take into account yearly or monthly variations, and some have a climatic component, the main climatic contributors to the FMP2 are precipitation and $\mathrm{ET}_{\mathrm{h}}$. In constructing the PVHM, a method similar to that used for the hydrologic model of the Central Valley (Faunt and others, 2009a) was developed to synthesize temperature and precipitation data for the FMP2; this method and associated results are summarized below. 
Table 9. Range of irrigation efficiencies for each crop for all water-balance subregions (WBS) within Pajaro Valley hydrologic model (PVHM), Pajaro Valley, California.'

$[-$, no data $]$

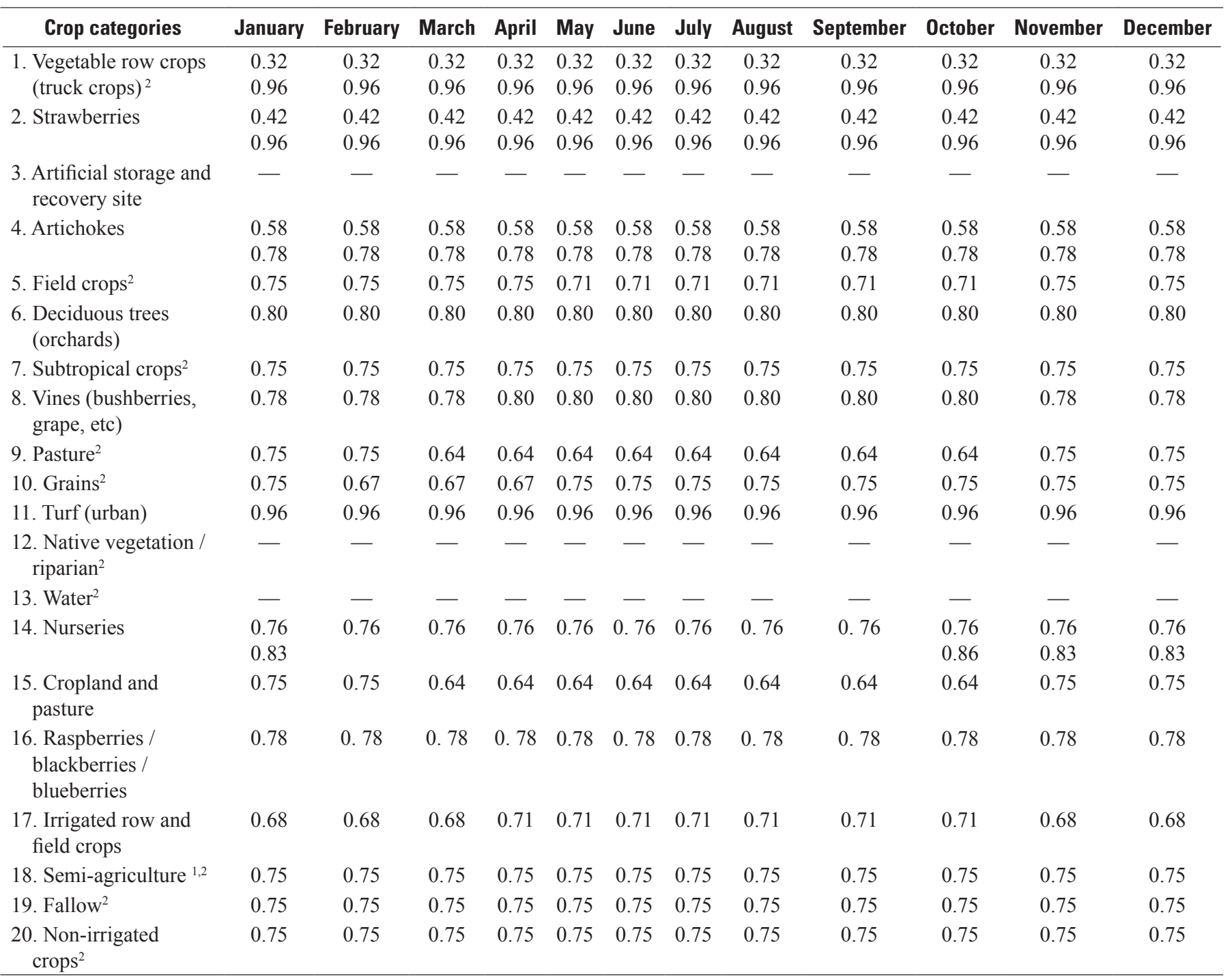

${ }^{1}$ Efficiencies are adjusted seasonally for wet and dry climatic periods with multipliers (see Model Calibration section).

${ }^{2}$ Efficiencies were specified for but are not used for nonirrigated land use.

\section{Precipitation}

Precipitation for the PVHM is specified through the FMP2 at the uppermost active cell for every month of the period of simulation. Gridded regional estimates of precipitation were obtained at a 1.24 mile (mi; 2 kilometer [km]) spatial resolution from the Climate Source (2006) for the period 1963-2005 and from the USGS (Alan Flint, USGS, written commun., 2010) for the period 2006-09. Comparison of monthly precipitation data from 4 weather stations distributed across the valley (figs. $1 A, 4 B$ ) to the gridded estimates indicate that the precipitation from these gridded sources preserve the total mass of precipitation measured at these stations. A monthly precipitation rate was bilinearly interpolated to the center of each 15 -acre model cell of the rotated model grid. The resulting monthly gridded precipitation values varied month to month; the general distribution reflected the long-term average shown in figure $4 A$. The precipitation is applied at an average daily rate equivalent to each monthly precipitation total on a cell-by-cell basis. 
If precipitation in excess of ET occurs, a portion of this residual precipitation becomes runoff, and another portion becomes deep percolation as groundwater recharge. The portions of runoff from precipitation vary by land-use type specified through the estimation of virtual-crop properties (table 7). Certain types of crops have additional runoff, such as strawberries that are planted with plastic mulch, raspberries that are shrouded in plastic canopy hoops, indoor nurseries that have elevated runoff of precipitation and not applied water, or some vegetable row crops planted in fields with tile drains. The runoff fractions for crops related to tile drain areas is redirected to the lower part of the streamflow network of Pajaro River as a semi-routed returnflow without simulating the network of tile drain canals.

\section{Reference Evapotranspiration $\left(\mathrm{ET}_{\mathrm{h}}\right)$}

Estimates of $\mathrm{ET}_{\mathrm{h}}$ can be derived using complex equations to explicitly represent physical processes or simpler empirical equations. The main difficulty encountered when using complex equations is the lack of data with a sufficient spatial and temporal distribution to make estimates on a daily basis. In addition, the detailed climatological data required for the complex equations (such as the Penman-Monteith equation, Snyder and Eching, 2002) are not available for many sites in California, especially prior to the operation of the California Irrigation Management Information System (CIMIS) stations started in 1987. Empirical equations use a small number of parameters (usually air temperature, difference in air temperature, and solar radiation) to estimate $\mathrm{ET}_{\mathrm{h}}$, and are well suited for application to sites with limited climatological data on a monthly basis. Samani (2000) determined that temperature and radiation explain at least 80 percent of $\mathrm{ET}_{\mathrm{h}}$. Hidalgo and others (2005) determined the seasonal cycle of $\mathrm{ET}_{\mathrm{h}}$ can be fairly accurately approximated from the seasonal cycle of net solar radiation (Rn) or average air temperature. The Hargreaves-Samani (H-S) equation (Hargreaves and Samani, 1982 and 1985; Hargreaves and others, 1985; Hargreaves, 1994; Hargreaves and Allen, 2003) provides an accurate estimate of $\mathrm{ET}_{\mathrm{h}}$ using a simple, reliable method with minimal data requirements and little sensitivity to weather station aridity (Hargreaves and Allen, 2003). Temperature data from the Climate Source (2006) for the period 1963-2005 were used to estimate $\mathrm{ET}_{\mathrm{h}}$. The $_{\mathrm{ET}}$ is approximated from the daily minimum and maximum air temperatures and the extraterrestrial solar radiation as follows:

$$
E T_{\mathrm{h}}=0.0023 * R a\left(\left(T_{\text {max }}+T_{\text {min }}\right) / 2 * 17.8\right)\left(T_{\text {max }}-T_{\text {min }}\right) / 2
$$

where

$T_{\max }$ is the maximum daily air temperature $\left({ }^{\circ} \mathrm{C}\right)$,

$T_{\min } \quad$ is the minimum daily air temperature $\left({ }^{\circ} \mathrm{C}\right)$, and

$R a \quad$ is the estimated extraterrestrial solar radiation (megaJoule/meter ${ }^{2} /$ day).

Jensen and others (1997) found the H-S equation to be one of the simplest and most accurate of the empirical methods for estimating $\mathrm{ET}_{\mathrm{h}}$. The Hargreaves method compared well with the Food and Agriculture Organization PenmanMonteith method in most parts of California, with the greatest differences occurring for days with extreme values of wind speed or relative humidity (Temesgen and others, 2005). The $\mathrm{H}-\mathrm{S}$ equation also compared well with the Penman-Monteith method on a global scale using a high-resolution monthly data set (Droogers and Allen, 2002). For the period 2006-09, the monthly average $\mathrm{ET}_{h}$ was derived from the Priestley-Taylor approximation (Hanson and others, 2012), which may provide a better estimate of $\mathrm{ET}_{\mathrm{h}}$.

Monthly $\mathrm{ET}_{\mathrm{h}}$ values for the FMP2 in the PVHM were derived from estimates of total monthly $\mathrm{ET}_{\mathrm{h}}$ values developed using the H-S equation (1963-2005; Hargreaves and Samani, 1982 and 1985; Snyder and Eching, 2002) and the Priestley Taylor (P-T) equation (2006-09). These raster estimates and gridded (1.24 mi, $2 \mathrm{~km}$ ) regional estimates were derived from minimum and maximum temperature the Climate Source (2006) and the USGS (Alan Flint, written commun., 2010). The gridded average monthly minimum and maximum temperature values were bilinearly interpolated to the center of each 15-acre cell of the rotated model grid. $\mathrm{ET}_{\mathrm{h}}$ was calculated at each active model cell for each month during the period of simulation using the H-S or P-T equations. $\mathrm{ET}_{h}$ varies month to month; the general spatial distribution reflects the long-term $\mathrm{ET}_{\mathrm{h}}$ averages (fig. $4 D$ ).

As part of CIMIS, CADWR has set up more than 120 weather stations throughout California since the 1980 s for use in calculating $\mathrm{ET}_{\mathrm{h}}$. Three CIMIS stations have been operated in Pajaro Valley: Green Valley Station No. 111 (active 1992-2008, now inactive), Watsonville West II Station No. 209 (active 2000-05), and Pajaro Station No. 129 (active 1995-present; fig. 1A). The Watsonville station (No. 209) has an average $\mathrm{ET}_{\mathrm{h}}$ of $39 \mathrm{in}$./yr. In contrast, the average annual $\mathrm{ET}_{\mathrm{h}}$ for the Pajaro Valley CIMIS stations ranges between 


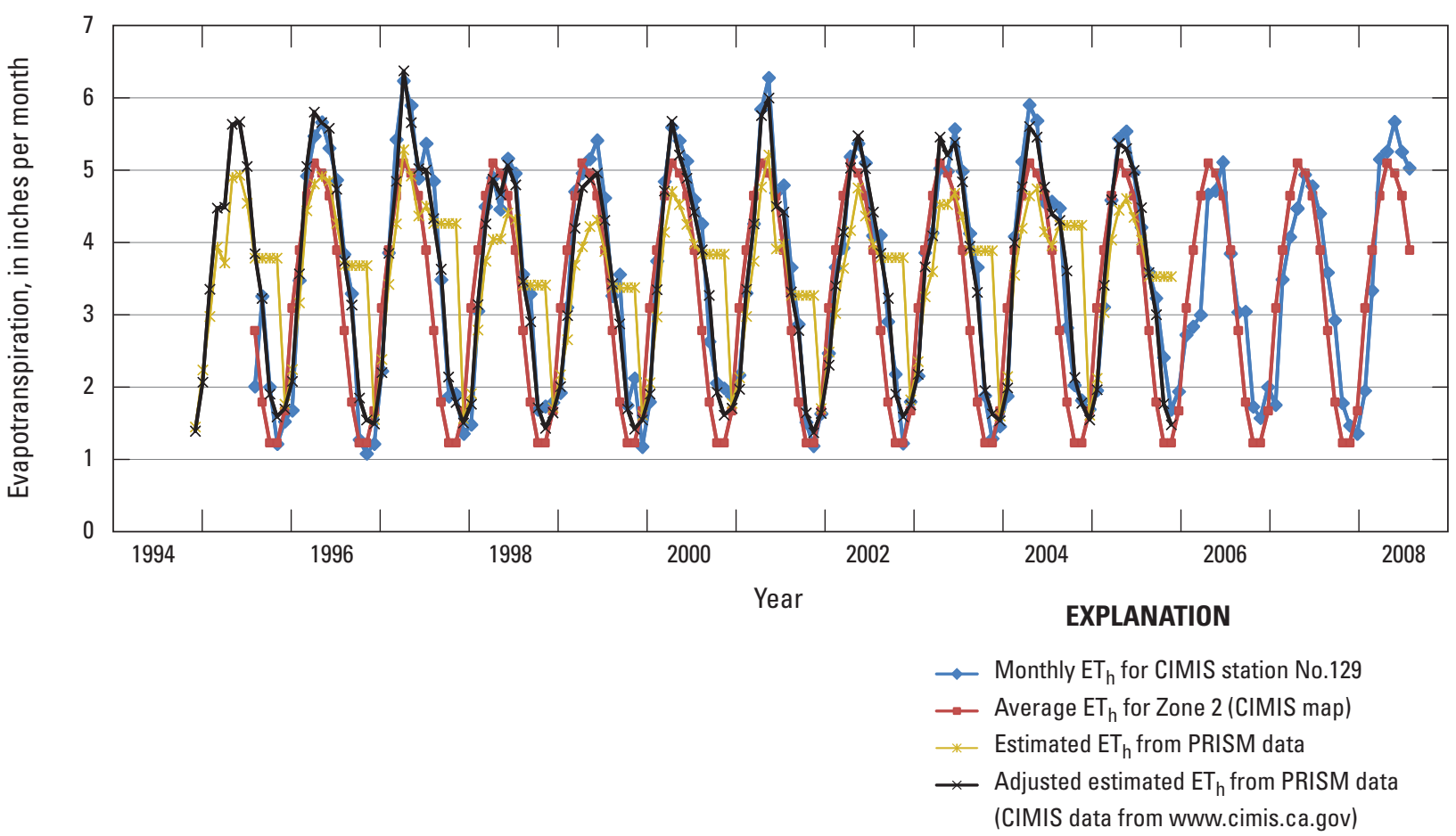

Figure 20. Monthly California Irrigation Management Information System (CIMIS) $\mathrm{ET}_{\mathrm{h}}$ and Hargrave-Semani $\mathrm{ET}_{\mathrm{h}}$ values through time for selected stations in Pajaro Valley, California.

42.5 in. at Pajaro (Station 129) and 43.8 in. further inland, at Green Valley (Station 111). As a reference crop, CIMIS uses a well-watered, actively growing, closely clipped grass that completely shades the soil. The $\mathrm{ET}_{\mathrm{h}}$ values estimated using the Hargreaves-Samani equation are correlated highly with corresponding CIMIS ET values. However, summer $\mathrm{ET}_{\mathrm{h}}$ values generally were underestimated and fall-winter $\mathrm{ET}_{h}$ values generally were overestimated by the H-S ET ${ }_{h}$ method in comparison with CIMIS values. These discrepancies occur in a coastal setting, where fog and other factors are not accounted for in the H-S method, which is based on temperature differences (California Department of Water Resources, 2007). The relation between CIMIS ET ${ }_{h}$ and the $\mathrm{H}_{-}$S estimated ET $_{h}$ using PRISM minimum and maximum temperature data suggest that the H-S method generally represents the temporal variation in $\mathrm{ET}_{\mathrm{h}}$ (fig. 20).
Several studies have reported methods for adjusting the constants in the Hargreaves-Samani equation to correct for local climate factors (Samani 2000; Droogers and Allen 2002). These methods correct differences for high $\mathrm{ET}_{h}$ values but do not address differences for low $\mathrm{ET}_{\mathrm{h}}$ values. An adjustment was made based on the average monthly fraction of $\mathrm{ET}_{\mathrm{h}}$ represented by the ratio of (CIMIS ET $\left.\mathrm{CH}_{\mathrm{h}}\right) /\left(\mathrm{H}-\mathrm{SET}_{\mathrm{h}}\right)$; the monthly $\mathrm{ET}_{\mathrm{h}}$ adjustments ranged from 0.42 in December to 1.21 in May and were applied to each month of all years of the simulation period. The adjusted monthly values (see table below) compare favorably with the CIMIS values for the period 1995-2005 (fig. 20). Additional adjustments to ET were made during model calibration to better match measured groundwater pumpage; the adjustments were to multipliers for the wet- and dry-year seasonal $\mathrm{K}_{\mathrm{c}}$ values.

\begin{tabular}{|c|c|c|c|c|c|c|c|c|c|c|c|c|}
\hline \multirow{2}{*}{$\begin{array}{c}\mathrm{ET}_{\mathrm{h}} \text { average } \\
\text { monthly value }\end{array}$} & Jan & Feb & Mar & Apr & May & Jun & Jul & Aug & Sept & Oct & Nov & Dec \\
\hline & \multicolumn{12}{|c|}{ (inch per month) } \\
\hline $\begin{array}{l}\text { California Irrigation Management Information System } \\
\text { (CIMIS) Station } 129 \text { (California Department of Water } \\
\text { Resources, 2007) }\end{array}$ & 1.60 & 2.05 & 3.46 & 4.49 & 5.38 & 5.37 & 5.08 & 4.63 & 3.80 & 3.19 & 1.88 & 1.58 \\
\hline Original Hargrave-Semani (H-S) Estimate & 1.66 & 2.21 & 3.08 & 3.95 & 4.46 & 4.67 & 4.42 & 4.16 & 3.74 & 3.74 & 3.74 & 3.74 \\
\hline $\begin{array}{l}\text { Adjusted Fraction of CIMIS Value of H-S Estimate } \\
\text { [dimensionless] }\end{array}$ & 0.96 & 0.93 & 1.13 & 1.14 & 1.21 & 1.15 & 1.15 & 1.11 & 1.02 & 0.85 & 0.5 & 0.42 \\
\hline
\end{tabular}




\section{Surface-Water Agricultural Supply}

In Pajaro Valley, the limited surface-water supply is simulated as a combination of non-routed surface-water deliveries to the three WBS that are served by the CDS, and semi-routed conveyances from the Harkins Slough diversion to the HS-ASR system for the period 2002-06 (figs. 2A, 5). The simulated movement of water from Harkins Slough Diversion to the HS-ASR is illustrated in figure $21 \mathrm{~A}$. The operation of the CDS is simulated for the last 8 years (2002-09) of the 43.25 years simulated by the PVHM with the fundamental hierarchy of deliveries shown in figure $21 \mathrm{~B}$.

The first eight years of the history of ongoing water deliveries of the CDS system were simulated in the last part of the simulation period of PVHM (fig. 21A). The deliveries of the CDS system were incrementally expanded during this period to almost full capacity by 2009. Deliveries to all regions continued during the entire eight-year period. The CDS deliveries are simulated as non-routed deliveries (NRDs) within FMP2 with the structure, progression, and hierarchy of deliveries shown in figure 21. The CDS deliveries to the Pajaro River mouth WBS ("virtual" farm 8) were simulated first where they receive water in lieu of some of the coastal pumpage for two years (2002-03; fig. 21 A, 22). In 2004, additional water deliveries to the Beach Road WBS (farm 17) were simulated to partially substitute for coastal pumpage. In the next two years (2005-06), additional water deliveries to the San Andreas WBS (farm 16) were simulated north of the Pajaro River (figs. 21A, 22). The CDS pipelines were extended in 2007 south of the Pajaro River into Monterey County and an additional WBS was added to the CDS, the Springfield Terrace subregion (WBS 9; figs. 21A, 22). Thus, four of the coastal the WBS served by CDS deliveries grew from 1 to four regions over the eight years of the CDS Project. Some adjacent regions in Monterey County that were eligible for CDS deliveries but elected to not receive them were designated as separate water-balance regions (WBS 18, 19, and 20; fig. 2A). Other coastal subregions in Santa Cruz County do not have access to the CDS yet (WBS 2, 3, 10, and $22)$. In these subregions, only precipitation and groundwater from coastal pumpage are sources of irrigation water.

The sources of water for the CDS have changed during the initial eight years of deliveries. The first source used was local runoff from Harkins Slough. PVWMA has the right to divert up to 2,000 acre-ft/yr from Harkins Slough from November through May. The historical records of diversions were used to simulate the historical reported diversions from Harkins Slough (Brian Lockwood, Pajaro Valley Water Management Agency, written commun., 2010). Local runoff that is available during the diversion months is diverted and delivered to the HS-ASR system pond, where it recharges the groundwater and is pumped back during the growing season from May to October. Harkins Slough is simulated as a river channel; monthly or longer-term storage is not currently simulated, and would require using the LAK package or SWR Process within PVHM. The demand of the HS-ASR system is formulated as a percolation requirement that is supplied from a diversion from the routed surface-water flows of the Harkins Slough. The demand is reduced during the recharge cycle months based on measured reduction of the infiltration rate (Schmid and others, 2009). The implementation of the CDS and related deliveries occurred in phases as the BMP components and pipeline facilities were constructed (fig. 22) and are reflected in changes in the simulation structure implemented in the PVHM, as described above and in figure 21. Local runoff is diverted from Harkins Slough when available, but water is not always available for diversion or left over from surface storage in the slough. The climatically variable amount of streamflow diversion is simulated using the SFR package linked to FMP2. In addition, because there is no in-line storage in the CDS, the delivery of water from the ASR system operation is augmented with pumpage from supplemental wells (fig. 21). With completion of the Recycled-Water Treatment Plant (RWF) in 2009, the CDS also received deliveries of treated waste water. In the model simulation, the RWF was assumed to operate during the months of March through October and is the highest priority delivery to the CDS during those months. The RWF water is blended with additional groundwater supplied by $\mathrm{CW}$ wells. Since there is no storage in the CDS system, a fourth supply from a connection to water from the City is used as a source of supplemental water for the period 2007-09. This City water source is used only if all other sources to the CDS are insufficient (figs. 21, 22).

The crop water demand in the water-balance subregions governs the amount of delivery required from the local supply sources (fig. 21). The user-specified order of simulated deliveries used with MF-FMP2 is aligned with the priorities set by PVWMA (fig. 21B). The simulated priorities for sources of irrigation water, from highest to lowest are, the ASR system, recycled water (during the operational months), remote supplemental wells, blend wells (replaced with a city connection in 2007), and, finally, local coastal wells (fig. 21B). Note that the priority of deliveries can change, as occurred in July and August of 2004, when the supplemental wells delivered most of the water to the CDS (fig. 21B). The priority also changes when the RWF, starting in 2009, is operating (fig. 22). Water deliveries from the RWF and city connection were specified in the PVHM based on the reported deliveries. Water deliveries from ASR and supplemental wellfields were simulated as demand-limited and are dependent on the estimated demand for irrigation water from FMP2 in each subregion. Water deliveries from the ASR "virtual" recovery well and supplemental well are also head-limited within the MNW package, with reduced or no pumpage below specified groundwater elevations at each well. 


\section{FARM PROCESS SIMULATION OF PROJECT OPERATIONS}

$\boldsymbol{A}$

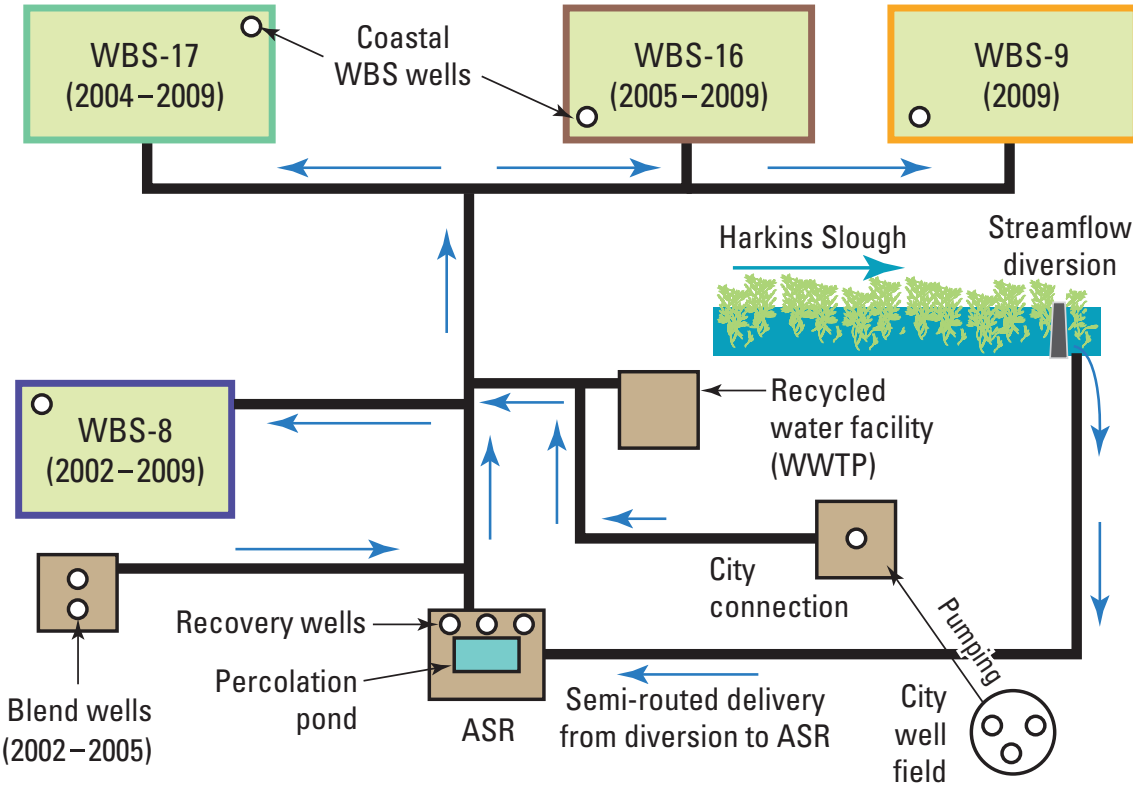

WBS is water balance subregion from fig $2 A$.

Modified from Hanson et al., 2008

WBS-8 Pajaro River mouth WBS-16 San Andreas

WBS-9 Springfield terrace WBS-17 Beach Road

B

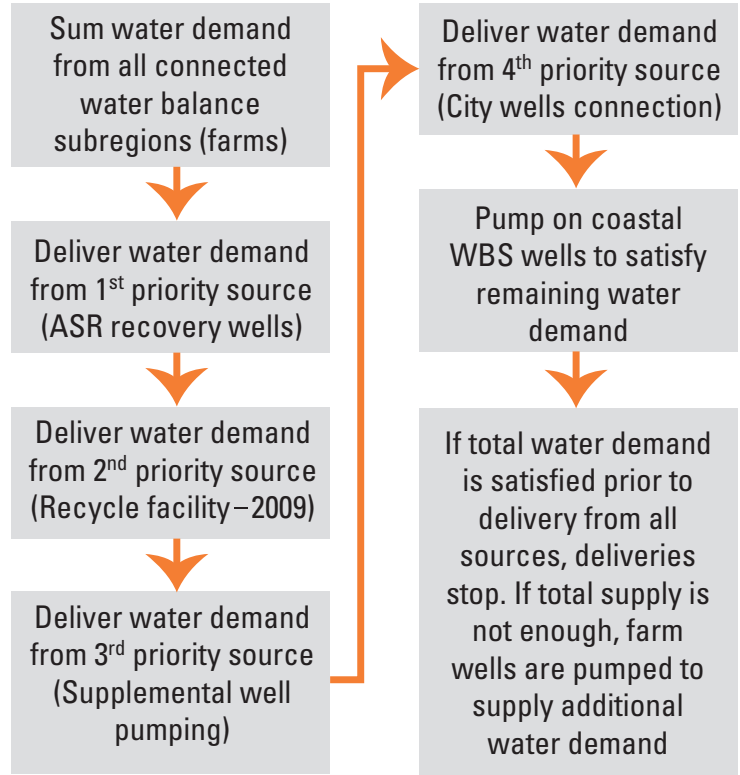

Modified from Hanson et al., 2008

Figure 21. $A$, Structure of local water deliveries, and $B$, hierarchy of simulated operation of the aquifer-storage-and-recovery (ASR) system and Coastal Distribution System (CDS) water deliveries to the regions serviced by the CDS, Pajaro Valley, California. 


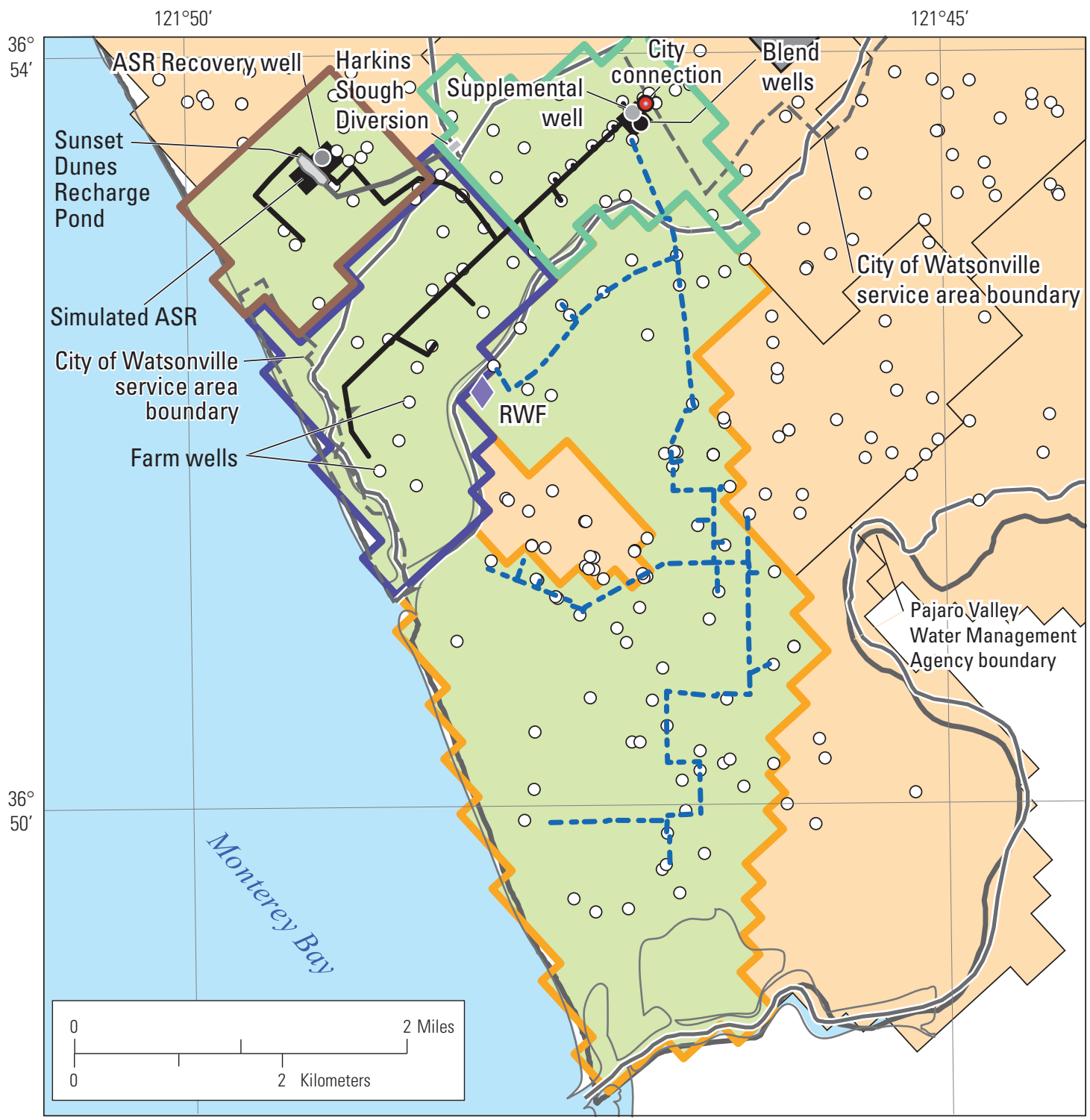

Modified from Hanson and others, 2010

\section{EXPLANATION}

Coastal region with Water balance subregions CDS connection Coastal region without CDS connection

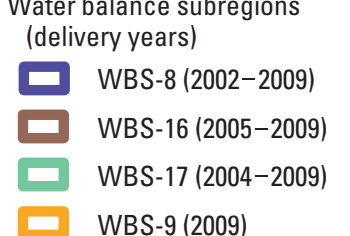

(delivery years)

WBS-8 (2002-2009)

WBS-16 (2005-2009)

WBS-9 (2009)
Original CDS (2002-2008), service to WBS-8, $-16,-17$

- Additional CDS (2009), service to WBS-9

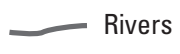

Recycled water facility (2009)

Figure 22. Coastal Distribution System (CDS) portion of the PVHM, selected water-balance subregions, selected wells, AquiferStorage-and-Recovery System (ASR), and CDS, Pajaro Valley, California. 
When water transfers are specified as deliveries, municipal-supply components (RWF and city connections deliveries) are the first priority, when available, to satisfy the TFDR. If more water is delivered than the WBS demands, the excess deliveries are returned to the streamflow network in the last outflow segment of the Pajaro River as it discharges to Monterey Bay (Schmid and Hanson, 2009).

The Harkins Slough diversion supplied about 5,330 acre-ft of water to the ASR system between 2002 and 2009 (fig. 23A). Some months such as January and February 2007, simulated diversions did not yield reported diversions. The CDS delivered 2,730 acre-ft during this period, which represents about 58 percent of the total water diverted and delivered to the ASR system. Thus, about 2,600 acre-ft of recharged water was not directly recaptured by the ASR system operation, resulting in a net increase in groundwater storage (Hanson and others, 2008). The completed CDS has the capacity to deliver about 7,150 acre-ft per year to coastal farms within the Pajaro Valley, provided there is a suitable supply of water for delivery. This could represent about 15 percent of the 48,300 acre-ft per year average agricultural pumpage in the study area for the period 2004-09 (Hanson and others, 2010). The PVHM successfully simulates the total and individual deliveries of the CDS system and is ultimately dominated in 2009 by the deliveries to the Springfield Terrace WBS (fig. 23C).

\section{Groundwater Agricultural Supply}

The groundwater supplied to each WBS is simulated by a series of single-layer "farm wells" or through multi-aquifer "farm wells" simulated with the linkage of FMP2 to MNW1 package (Halford and Hanson, 2002). The FMP2 does not currently allow more than one multi-aquifer farm well in the same cell. Therefore, multi-aquifer farm wells residing in the same cell and simulated using MNW1 were reduced to a single priority well; this occurred in 30 model cells. The priority for simulating farm wells as multi-aquifer was given first to those wells with more than 10 percent of the total screened interval in multiple layers, then to wells of largest capacity, and then to wells with longest history of use. This procedure resulted in up to 834 single-aquifer farm wells. There are 198 multi-aquifer farm wells simulated as multiaquifer wells, representing about 19 percent of all farm wells (fig. 6). All remaining wells were simulated as single-aquifer farm wells.
Agricultural groundwater pumpage requirements are estimated by the FMP2 after water supplied by precipitation, after any groundwater uptake is calculated, and after any deliveries are accounted for, is subtracted from the total actual ET on a cell-by-cell basis. The remainder of the water needed for agricultural land is the crop irrigation requirement (CIR) that is summed on a cell-by-cell basis within each WBS. CIR is the TFDR which includes other potential losses from inefficient irrigation. The TFDR that is required from groundwater pumpage is estimated after surface-water imports and exports from routed and non-routed deliveries have been subtracted from the TFDR, which occurs only in Pajaro Valley in 2002-09 and is related to the operation of the Coastal Delivery System. Thus, prior to 2002, the TFDR was solely satisfied by the groundwater pumpage throughout the valley. Comparison of simulated and reported metered pumpage for 2002-09, and model calibration to improve correspondence, provides greater confidence in simulation estimates of historical unmetered pumpage for 1963-99 than would be possible without such an approach.

\section{Net Recharge}

The net recharge in a WBS is defined as inefficient losses to groundwater recharge after consumption due to excess irrigation and excess precipitation, reduced by losses to surface-water runoff and ET from groundwater (Schmid and others, 2006a). Alternatively, the net recharge can be defined in terms of consumptive use: the portion of irrigation and precipitation not consumptively used by plants reduced by losses to surface-water runoff and ET from groundwater. The fraction of losses to surface-water runoff is specified separately for irrigation and precipitation. The ET from groundwater is subtracted from the potential net downward flux to the uppermost aquifer. Hence, the simulated net recharge to groundwater is affected by user-specified and head-dependent parameters. This conceptual model of net recharge is physically valid, given the following assumptions: deep percolation beyond the active root zone is equal to groundwater recharge, recharge is simulated without delay and represents an instantaneous source of flow into the aquifer, ET from groundwater equals an instantaneous outflow from aquifer storage during any time step within a monthly stress period, and the net change in soil moisture storage for irrigated agricultural areas for periods of weeks to months is negligible (Schmid and others, 2006a). The net recharge to the aquifers is applied to the uppermost active model cells in each WBS. 

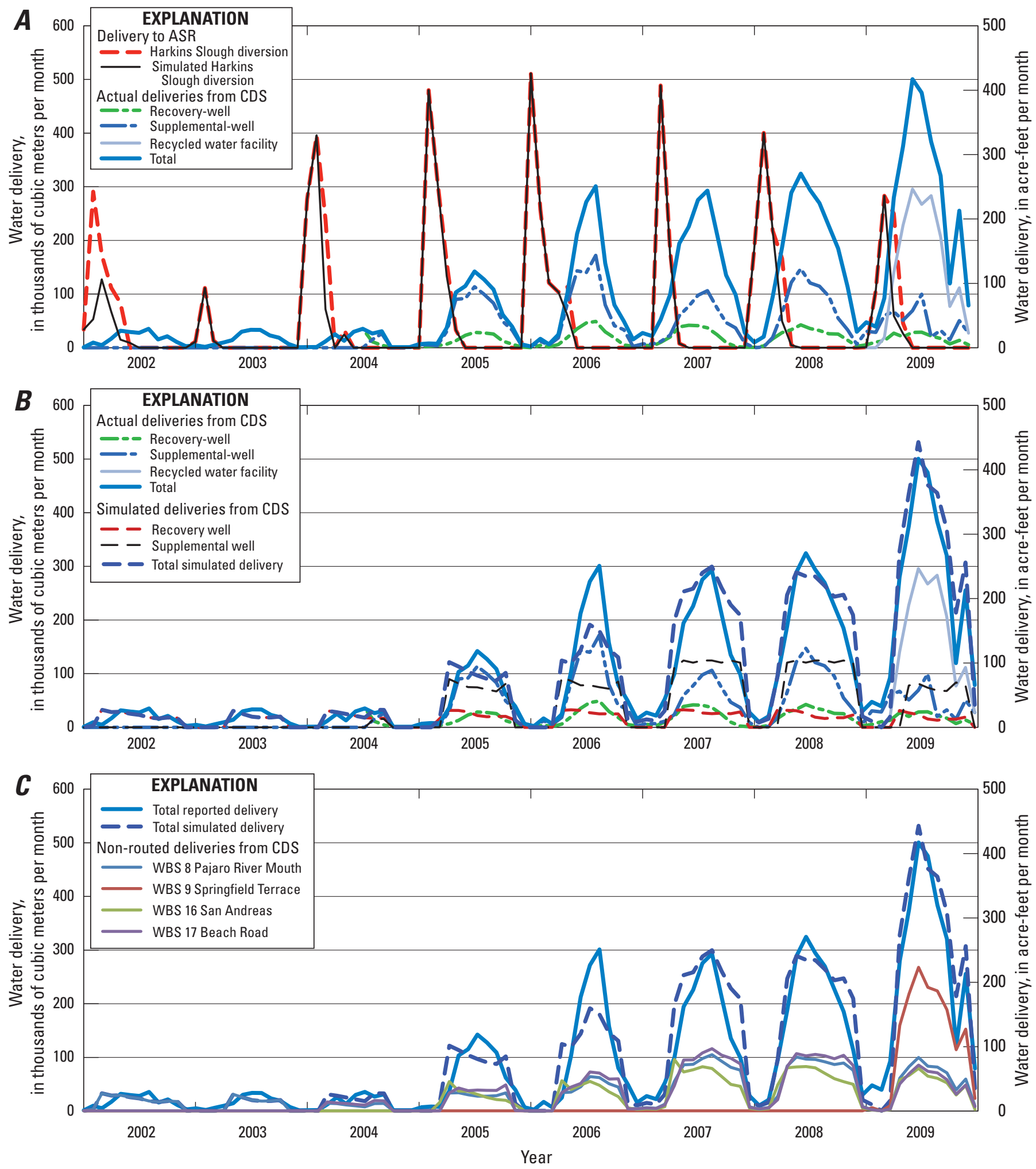

Figure 23. $A$, Simulated and reported deliveries to the aquifer-storage-and-recovery (ASR) system; $B$, simulated and reported deliveries from the Coastal Delivery System (CDS); and $C$, simulated and reported total deliveries from the CDS, and by water budget subarea (WBS), Pajaro Valley, California. 


\section{Aquifer Characteristics}

The alluvial deposits in Pajaro Valley constitute a layered aquifer system of terrestrial and marine source. The deposits can be classified into three aquifers, each of which can be characterized by variations in hydraulic properties that are based on the textural distribution of coarse and fine-grained sediments and zones in which the sediments are derived from particular depositional environments. The water-transmitting properties of the aquifers, as represented by horizontal $\left(\mathrm{K}_{\mathrm{h}}\right)$ and vertical $\left(\mathrm{K}_{\mathrm{v}}\right)$ hydraulic conductivity) and vertical anisotropy, are functions of depositional environment and lithology that differ according to grain size and the degree of sorting of the sediments. Thus, considerable variation exists in the hydraulic properties of the aquifers from place to place. The relation between hydrogeologic units, lithology, and selected water-transmitting properties (hydraulic conductivity and vertical anisotropy) has been developed in many previous studies (Hanson and others, 1990, 2003, 2004; Hanson and Benedict, 1993, Laudon and Belitz, 1991; Phillips and Belitz, 1991; Leighton and others, 1994; Fio and Leighton, 1995; Belitz and Phillips, 1995; Burow and others, 2004, Phillips and others, 2007; and Faunt and others, 2009a,b).

\section{Textural Analysis}

Lateral and vertical variations in sediment texture affect the direction and rate of groundwater flow through the sediments as well as the magnitude and distribution of aquifersystem storativity. Therefore, the textural distribution was used to define the vertical and lateral hydraulic conductivity and storage property distributions for the hydrologic model. As in many of the previous studies identified above, this textural distribution was based on information about sediment texture derived primarily from drillers' logs, and supplemented with geologic and geophysical logs. The primary variable used for the textural analysis was the percentage of sediment thickness per depth interval composed of coarse-grained materials; the complement is the percentage of fine-grained materials. Textural data were compiled from drillers' logs of 824 boreholes drilled in the Pajaro Valley (fig. $3 A$ ).
A database was constructed to organize information on well construction and subsurface lithology in the study area using the database design of Burow and others (2004). Drillers' logs for 824 wells containing adequate location and lithology information were digitized out of 1,387 available logs. The deepest of these wells is $1,015 \mathrm{ft}$ and the wells average about $350 \mathrm{ft}$ deep. These drillers' logs include 8,518 lithologic descriptions for particular depth intervals.

Texture is defined as the percentage of coarse-grained sediment present within a specified subsurface depth interval (Hanson and others, 1990; Laudon and Belitz, 1991). Each lithologic log interval was classified according to a discrete binary texture classification of either "coarse-grained" or "fine-grained" sediments on the basis of the major descriptor in each entry of the logged intervals. In this study, coarsegrained sediment is defined as that consisting principally of sand, gravel, pebbles, boulders, cobbles, or conglomerate. Fine-grained sediment is defined as that consisting principally of clay, lime, loam, mud, or silt.

The sediment texture data in the Pajaro Valley was assigned to six hydrogeologic (and model) layers based on the reanalysis of the hydrogeology (fig. 3). The texture distribution was estimated independently for each model layer. The fraction of coarse and fine-grained sediments within each layer was geostatistically estimated on a cellby-cell basis. The alluvial unit was split into two zones, an upper, coarse-grained aquifer and a lower, fine-grained confining unit. The upper Aromas was spatially subdivided into two subregions representing the northwestern aeolian and eastern fluvial facies. Properties of the variogram models for each of the units and zones for the twodimensional ordinary Kriging are summarized in table 10. The distribution of estimated percentage of coarse-grained sediments for layers 1, 3, 5, and 6 are shown in figure 24; the estimated percentage of fine-grained sediments for layers 2 and 4 are shown in figure 25. Offshore estimates for all layers are extrapolations based on extensions of the nearshore estimates and therefore have greater uncertainty.

Table 10. Summary of variogram model properties for the Pajaro Valley hydrogeologic units.

[All variogram models fitted with 12 lags at distance intervals of 700 meters]

\begin{tabular}{lcccc}
\hline \multicolumn{1}{c}{$\begin{array}{c}\text { Hydrogeologic } \\
\text { unit / subunit }\end{array}$} & $\begin{array}{c}\text { Variogram } \\
\text { model }\end{array}$ & $\begin{array}{c}\text { Nugget / sill } \\
\text { (dimensionless) }\end{array}$ & $\begin{array}{c}\text { Major / minor range } \\
\text { (meters) }\end{array}$ & $\begin{array}{c}\text { Anistropy } \\
\text { direction / ratio }\end{array}$ \\
\hline Alluvial aquifer & Gaussian & $0.13 / 0.04$ & $6,000 / 3,000$ & $\mathrm{~N} 72 \mathrm{E} / 2: 1$ \\
Alluvial confining layer & Gaussian & $0.15 / 0.05$ & $6,000 / 4,000$ & $\mathrm{~N} 15 \mathrm{~W} / 3: 2$ \\
Upper Aromas aeolian subunit & Gaussian & $0.085 / 0.02$ & $5,000 / 2,500$ & $\mathrm{~N} 90 \mathrm{~W} / 2: 1$ \\
Upper Aromas fluvial subunit & Gaussian & $0.09 / 0.04$ & $7,000 / 3,000$ & $\mathrm{~N} 0 \mathrm{~W} / 2: 1$ \\
Aromas confining layer & Gaussian & $0.11 / 0.05$ & $6,500 / 3,000$ & $\mathrm{~N} 60 \mathrm{~W} / 2.2: 1$ \\
Lower Aromas & Gaussian & $0.095 / 0.06$ & $6,000 / 3,000$ & $\mathrm{~N} 60 \mathrm{~W} / 2: 1$ \\
Purisima/Bedrock formation (undifferentiated) & Gaussian & $0.09 / 0.07$ & $8,300 / 4,000$ & $\mathrm{~N} 0 \mathrm{~W} / 2: 1$ \\
\hline
\end{tabular}




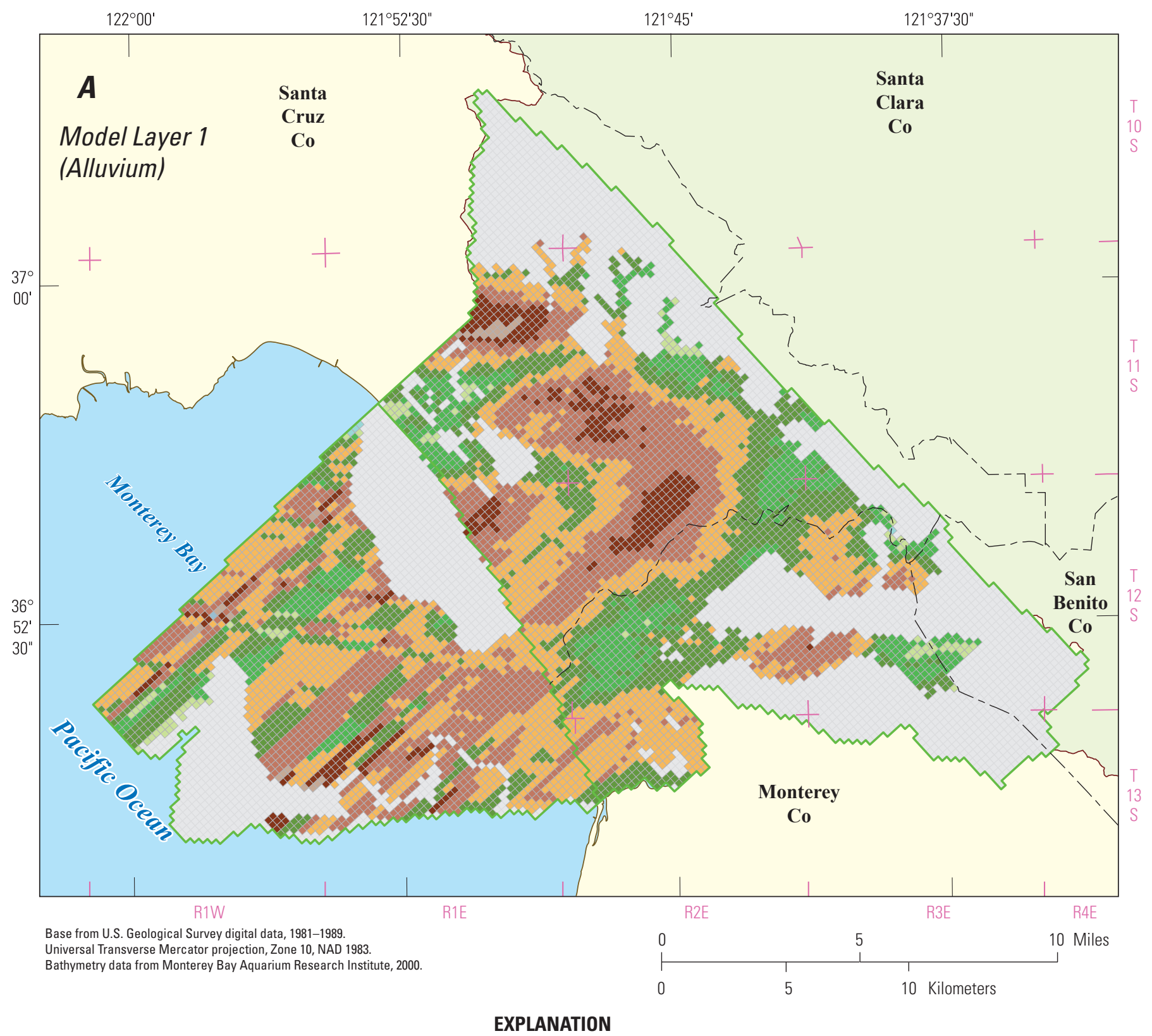

EXPLANATION
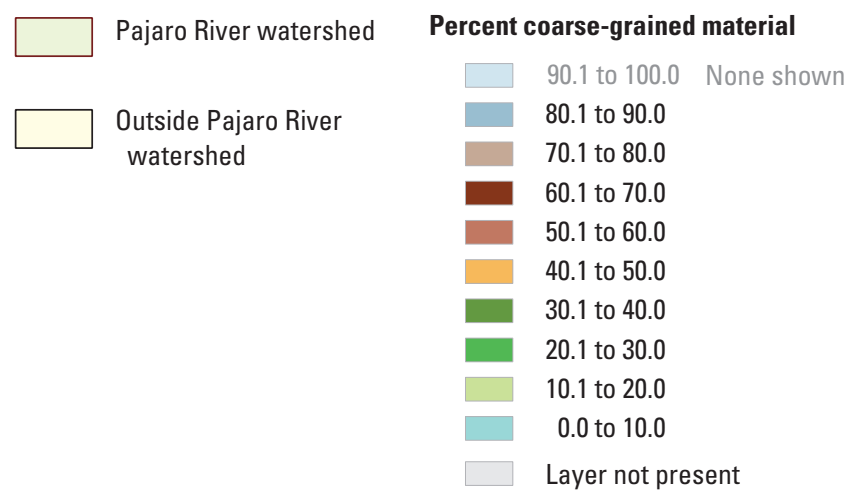

Figure 24. Distribution of coarse-grained deposits for $A$, layer $1 ; B$, layer $3 ; C$, layer 5 ; and $D$, layer 6 of the hydrologic model, Pajaro Valley, California. 


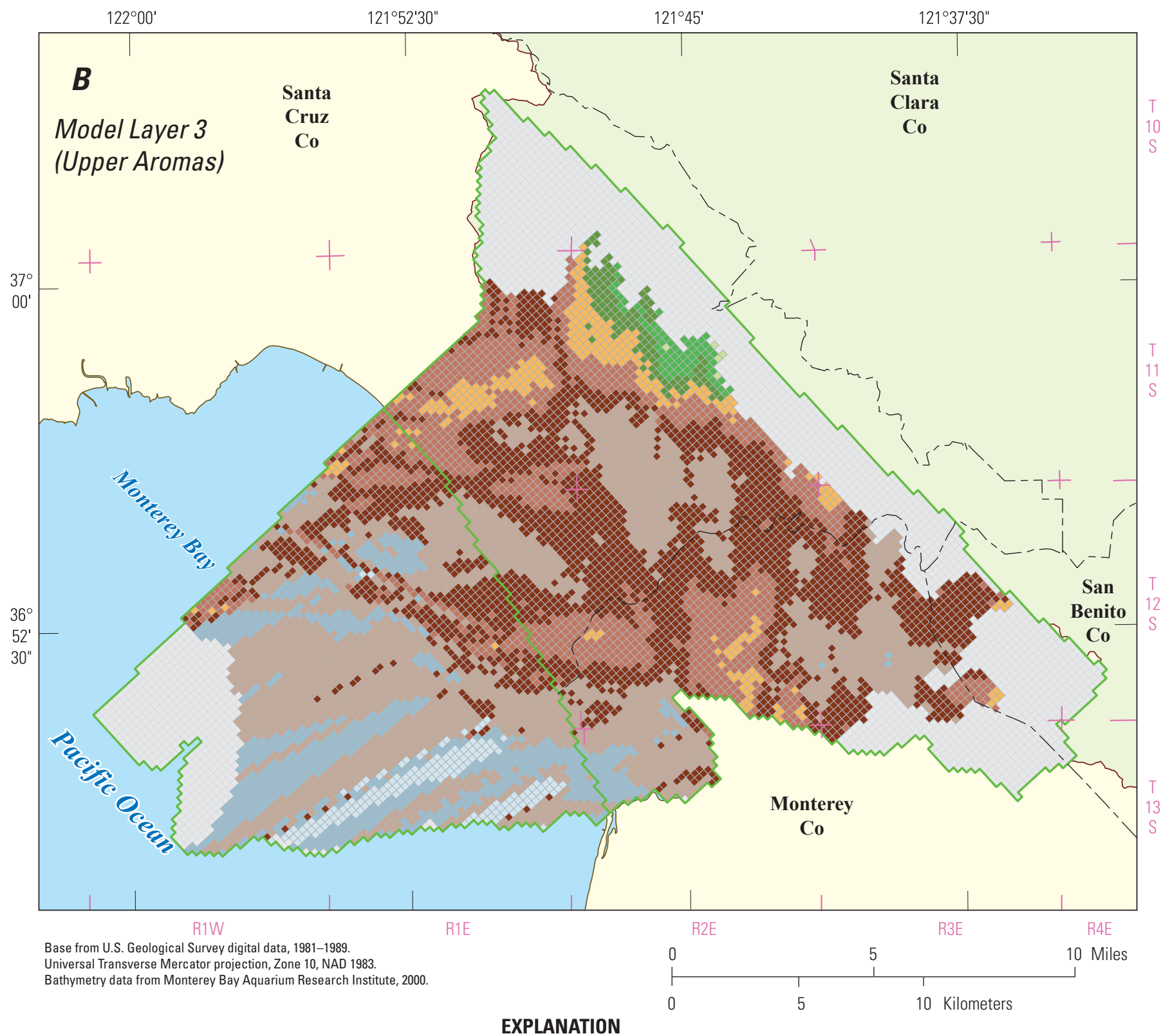

Percent coarse-grained material

Pajaro River watershed $\quad \square \quad \square .1$ to 100.0

80.1 to 90.0

Outside Pajaro River $\quad 70.1$ to 80.0

watershed 60.1 to 70.0

50.1 to 60.0

40.1 to 50.0

30.1 to 40.0

20.1 to 30.0

10.1 to 20.0

0.0 to 10.0 None shown

Layer not present

Figure 24. - Continued 


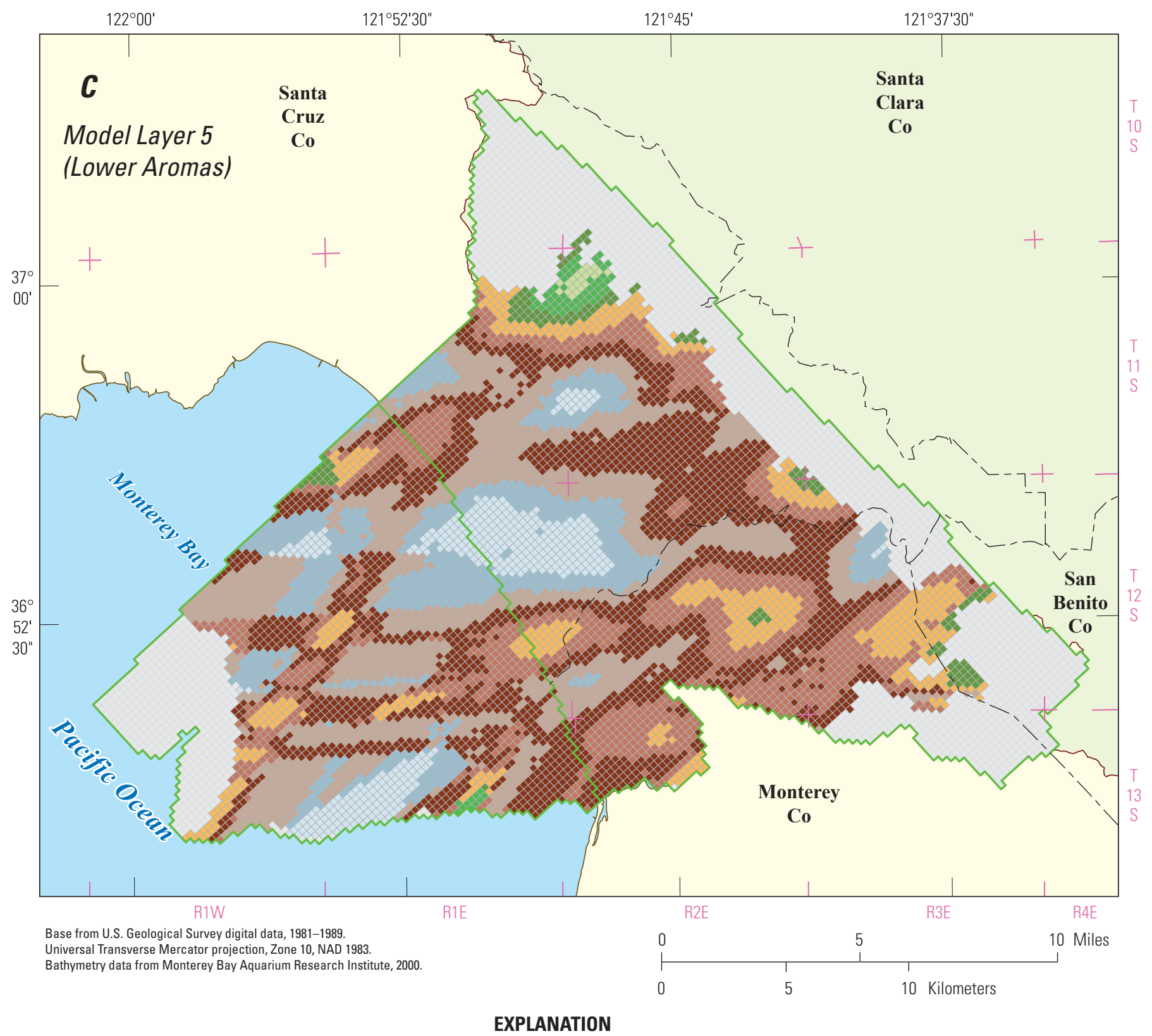

EXPLANATION

\section{Pajaro River watershed Percent coarse-grained material}

90.1 to 100.0

80.1 to 90.0

70.1 to 80.0

60.1 to 70.0

50.1 to 60.0

40.1 to 50.0

30.1 to 40.0

20.1 to 30.0

10.1 to 20.0

0.0 to 10.0 None shown

Layer not present

Figure 24. - Continued 


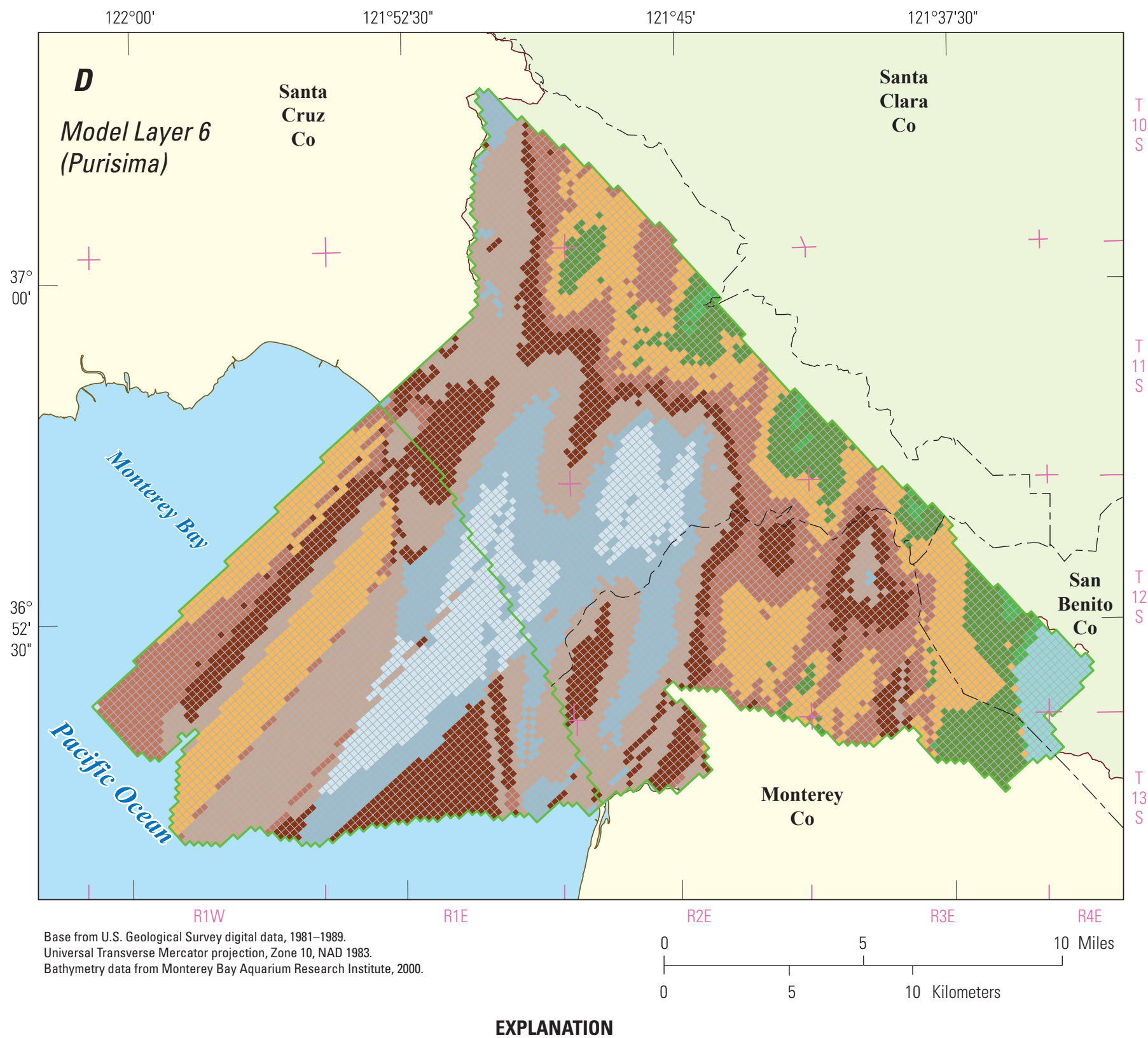

EXPLANATION

\begin{tabular}{|l|r|}
\hline Pajaro River watershed & Percent coarse-grained \\
\hline & 90.1 to 100.0 \\
\hline & 80.1 to 90.0 \\
\hline Outside Pajaro River & 70.1 to 80.0 \\
watershed & 60.1 to 70.0 \\
& 50.1 to 60.0 \\
& 40.1 to 50.0 \\
& 30.1 to 40.0 \\
& 20.1 to 30.0 \\
& 10.1 to 20.0 \\
& 0.0 to 10.0
\end{tabular}

Figure 24. - Continued 


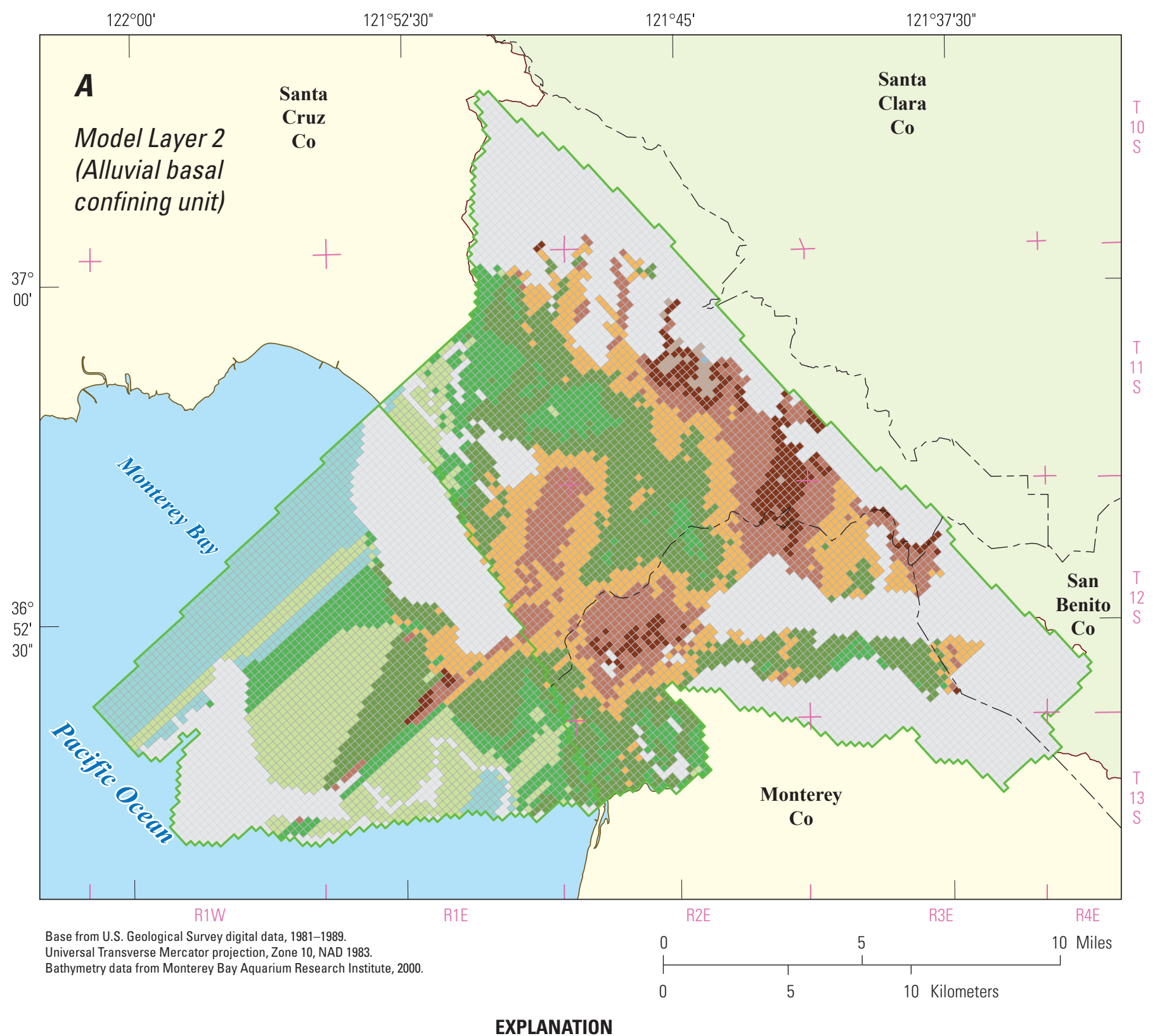

EXPLANATION

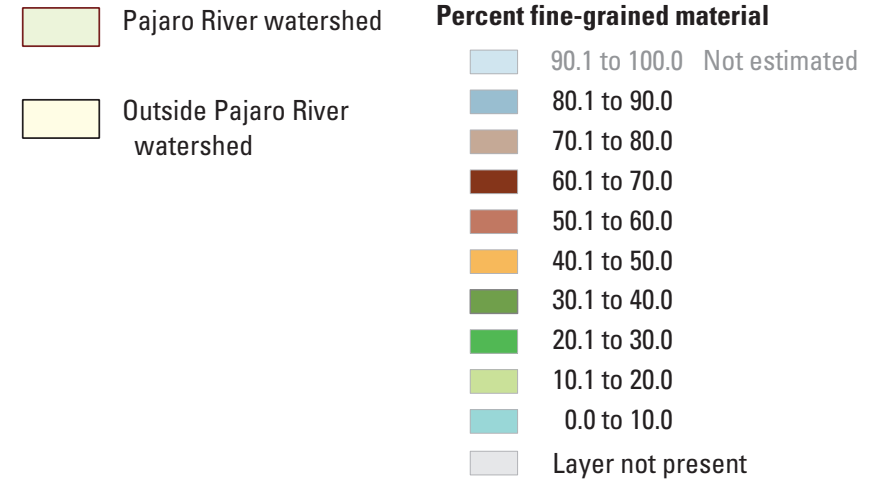

Figure 25. Distribution of fine-grained deposits for $A$, the alluvial confining unit (model layer 2 ) and $B$, the upper Aromas confining unit (model layer 4) Pajaro Valley, California. 


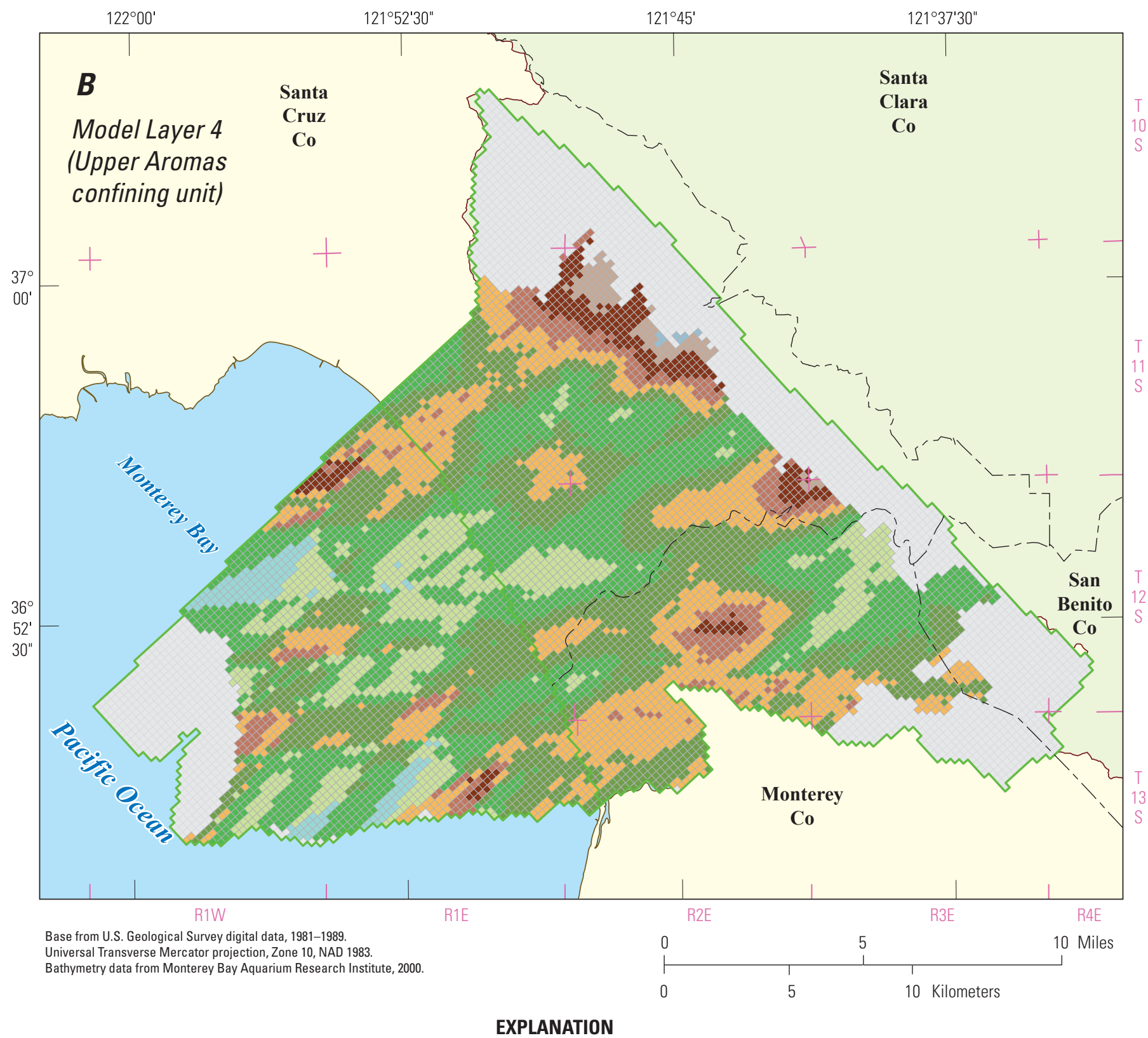

EXPLANATION

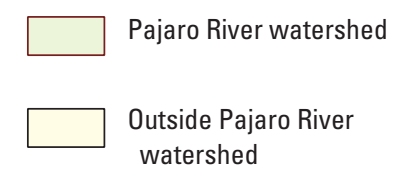

Percent fine-grained material

\begin{tabular}{|l|l|}
\hline & 90.1 to $100.0 \quad$ Not estimated \\
& 80.1 to 90.0 \\
& 70.1 to 80.0 \\
60.1 to 70.0 \\
50.1 to 60.0 \\
40.1 to 50.0 \\
30.1 to 40.0 \\
20.1 to 30.0 \\
10.1 to 20.0 \\
\hline 0.0 to 10.0 \\
\hline \\
\hline \\
\hline \\
\hline
\end{tabular}

Figure 25. - Continued 


\section{Hydraulic Properties}

Textural-based hydraulic properties were estimated by hydrogeologic unit (model layer) on the basis of the distribution of sediment texture derived from drillers' logs, geologic logs, and geophysical logs. The hydraulic properties of an aquifer are its transmission and storage properties. The transmission properties of the Pajaro Valley aquifer are represented by the hydraulic conductivity $(\mathrm{K})$ in this study. Equivalent horizontal $\left(\mathrm{K}_{\mathrm{h}}\right)$ and vertical $\left(\mathrm{K}_{\mathrm{v}}\right)$ hydraulic conductivities are assumed to be correlated to sediment texture (the fraction of coarse-grained and fine-grained sediment). The method used for estimating $\mathrm{K}_{\mathrm{h}}$ and $\mathrm{K}_{\mathrm{v}}$ for each cell within a model layer makes use of the estimated binary sediment texture for each cell within the layer and estimates of the horizontal and vertical hydraulic conductivity of each textural end member (100 percent coarse-grained, and 100 percent fine-grained) for the layer.

Faunt and others (2009a) identify the power mean as a useful means for estimating hydraulic conductivity values. In addition, their work includes a review of the literature that describes the use of the power mean for calculating hydraulic conductivity. A power mean is a mean (M) of the form:

$$
M^{p}(x)=\left(\frac{1}{n} \sum_{k=1}^{n} x_{k}^{p}\right)^{1 / p}
$$

where

$$
\begin{array}{ll}
p & \text { is the averaging power-mean exponent, } \\
n & \text { is the number of elements being averaged, and } \\
x_{k} & \text { is the } k^{\text {th }} \text { element in the list. }
\end{array}
$$

The horizontal hydraulic conductivity $\left(\mathrm{K}_{\mathrm{h}, \mathrm{i}}\right)$ was calculated as the weighted arithmetic mean $(\mathrm{p}=1.0$ in eqn. 2) of the hydraulic conductivities of the coarse-grained $\left(\mathrm{K}_{\mathrm{c}}\right)$ and fine-grained $\left(K_{f}\right)$ lithologic end members and the sediment texture for each $\left(i^{\text {th }}\right)$ model cell:

$$
K_{h, i}=\left[K_{c} F_{c, i}+K_{f} F_{f, i}\right]
$$

where

$$
\begin{gathered}
F_{c, i} \quad \text { is the fraction of coarse-grained sediment in a } \\
\text { cell, estimated from sediment texture data } \\
\text { as described in the previous section, and } \\
F_{f, i} \quad \text { is the fraction of fine-grained sediment in a } \\
\text { cell }\left(1-F_{c, i}\right) .
\end{gathered}
$$

Because $K_{f}$ is much smaller than $K_{c}$, the arithmetic mean heavily weights the coarse-grained end member for horizontal hydraulic conductivity.
Vertical hydraulic conductivity between model layers $\left(K_{v, k+1 / 2}\right)$ was calculated as the weighted power mean of the hydraulic conductivities of the coarse-and fine-grained lithologic end members (Faunt and others, 2009b):

$$
K_{v, k+1 / 2}=\left[F_{c, k+1 / 2} K_{c}^{p}+F_{f, k+1 / 2} K_{f}^{p}\right]^{1 / p}
$$

where

$$
\begin{array}{cc}
F_{c, k+1 / 2} & \begin{array}{c}
\text { is the fraction of coarse-grained sediment } \\
\text { between layer midpoints, and }
\end{array} \\
F_{f, k+1 / 2} & \text { is the fraction of fine-grained sediment } \\
\text { between layer midpoints. }
\end{array}
$$

The harmonic mean is a weighted power mean with the exponent $\mathrm{p}=-1.0$ in eqn. 4 and results in increased vertical anisotropy. The geometric mean is a weighted power mean with $\mathrm{p}=0.0$ in eqn. 4 and results in decreased vertical anisotropy. Phillips and Belitz (1991) determined that vertical conductivities could be calculated by using either weighted harmonic or weighted geometric means. Belitz and others (1993) represented the vertical conductivities with the weighted harmonic mean. Faunt and others (2009b) calculated the vertical conductivities as power means in which $\mathrm{p}$ varied between -1.0 (the harmonic mean) and 0.0 (the geometric mean). The relation between hydraulic conductivity and percentage coarse-grained deposits based on hydraulic conductivity end members and exponent of the power mean is nonlinear (fig. 26). $K_{f}$ is sensitive to the averaging method used. Both the harmonic and geometric means more heavily weight the fine-grained end member and as a result, the calculated vertical hydraulic conductivity is much lower than the horizontal. Dimitrakopoulos and Desbarats (1993) determined that the value of $p$ depended to some extent on the size and thickness of the grid blocks used to discretize the model domain; smaller grid cells resulted in smaller values of $p$. An initial value of the exponent $p$ was set for each model layer and adjusted during model calibration. The resulting values of $p$ were -0.9 for the Alluvial aquifer (layer 1), -0.5 for the alluvial confining layer (layer 2), -0.8 for the upper Aromas aquifer layer (layer 3), -0.25 for the Aromas confining unit (layer 4 ), -0.35 for the lower Aromas aquifer, and -0.95 for the Purisima aquifer (layer 6). While endmember $\mathrm{K}$ values, and $\mathrm{p}$ values change during calibration, it is the resulting $\mathrm{K}$ distribution that is most significant, not the $\mathrm{p}$ values or end-member K's.

Few aquifer tests have been conducted in the Pajaro Valley, but transmissivity and hydraulic conductivity can be approximated from specific capacity data available for supply wells from Central and Soquel Creek Water Districts (Johnson 


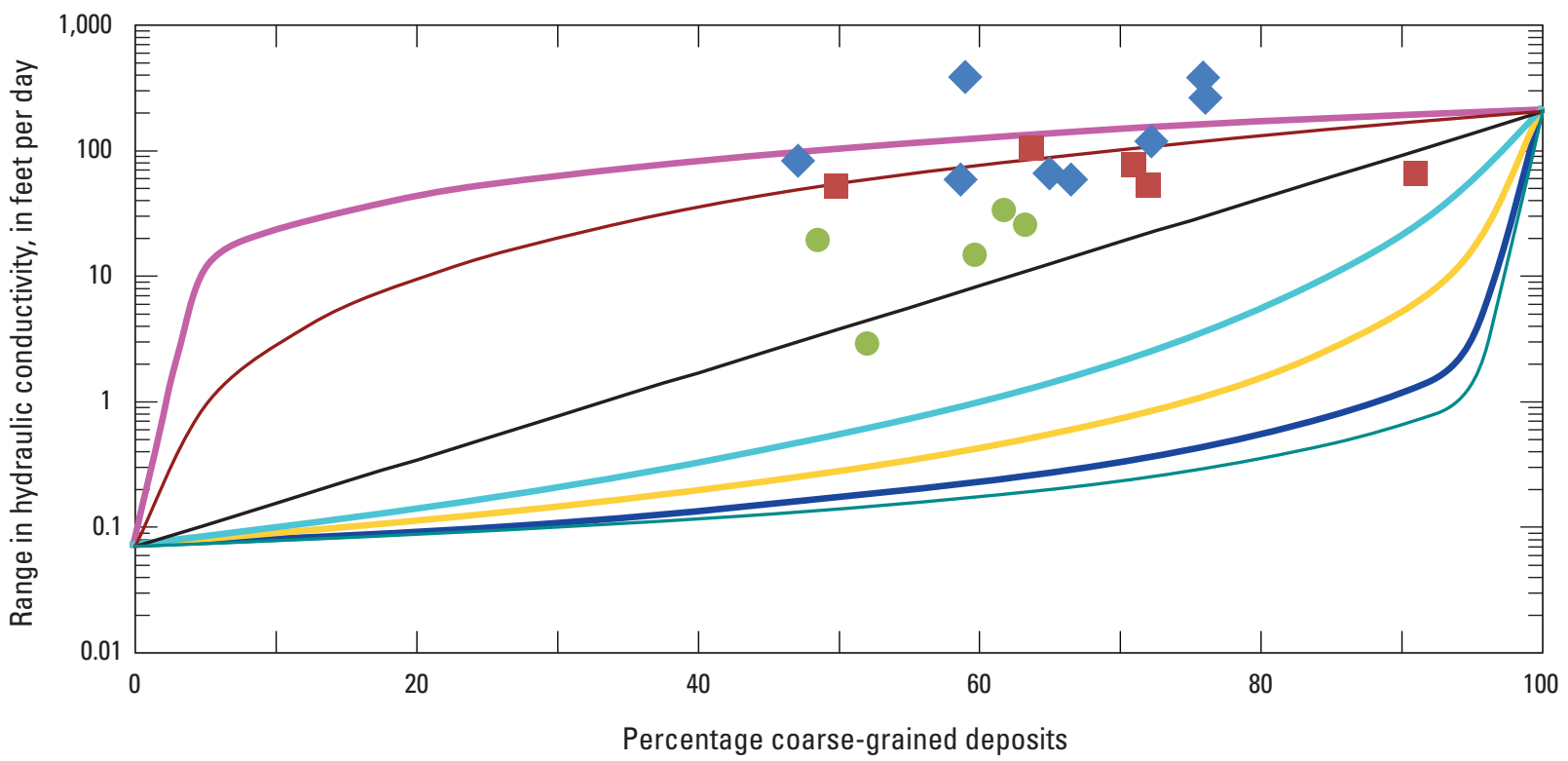

\section{EXPLANATION}

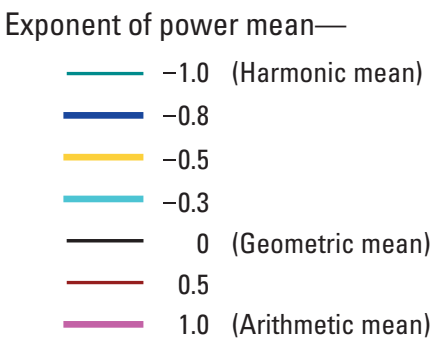

Estimates of lateral hydraulic conductivity from selected water-supply wells-

Upper Aromas

Lower Aromas

Purisima

Figure 26. Relation of hydraulic conductivity and percentage coarse-grained deposits based on hydraulic conductivity end members and exponent of the power mean, with selected values from aquifer tests or specific capacity tests in Pajaro Valley, California.

and others, 2004; Johnson, 2006) and from the CW (Keith Kimes, written commun., 2008). The revised PVIGSM model provides another indirect estimate of hydraulic properties that were used as initial estimates for model calibration. (table 11). The hydraulic conductivities $\left(\mathrm{K}_{\mathrm{h}}\right.$ and $\mathrm{K}_{\mathrm{v}}$ ) from the calibration of the original model (PVIGSM) ranged from 0.35 to $35 \mathrm{ft} / \mathrm{d}$ for the alluvial layer and transmissivity values ranged from 6,500 to $13,000 \mathrm{ft} / \mathrm{d}$ for the lower layers (table 11). The geometric mean of hydraulic conductivity for the upper and lower Aromas and Purisima model layers estimated from specific capacity tests of selected supply wells are 78,69 , and $23 \mathrm{ft}$ per day, respectively. The 100 percent coarse-grained adjusted values are 118,109, and $39 \mathrm{ft}$ per day, respectively. One recent single-well aquifer step-test was completed on a well (BW2) that penetrates the upper and lower Aromas in the study area (Pajaro Valley Water Management Agency, written commun., 2008). The estimated hydraulic conductivity value from this test was $66 \mathrm{ft}$ per day from an estimated transmissivity of $16,619 \mathrm{ft}^{2} /$ day, with an assumed storage coefficient of $5 \times 10^{-4}$ and total screened thickness of $250 \mathrm{ft}$. The equivalent hydraulic conductivity for 100 percent coarsegrained material was estimated to be about $86 \mathrm{ft} / \mathrm{day}$. This estimate is based on the average fractions of coarse-grained material and layer thicknesses in this model cell of 0.65 for $325 \mathrm{ft}$ of upper Aromas and $0.91 \mathrm{for} 266 \mathrm{ft}$ of Lower Aromas, respectively. Previous estimates of hydraulic conductivity for the Purisima Formation aquifers include those from slug tests of wells in the Marina area that range from 6 to $15 \mathrm{ft} / \mathrm{day}$ (Hanson and others, 2002). 
Table 11. Summary of hydraulic properties estimated from the Pajaro Valley Hydrologic Model calibration (bold) and previous groundwater models with grain-size adjusted values from selected aquifer tests.

[Model reported values from Teghavi and Smith (1999d) and in brackets from Johnson and others (1988). —, no estimate]

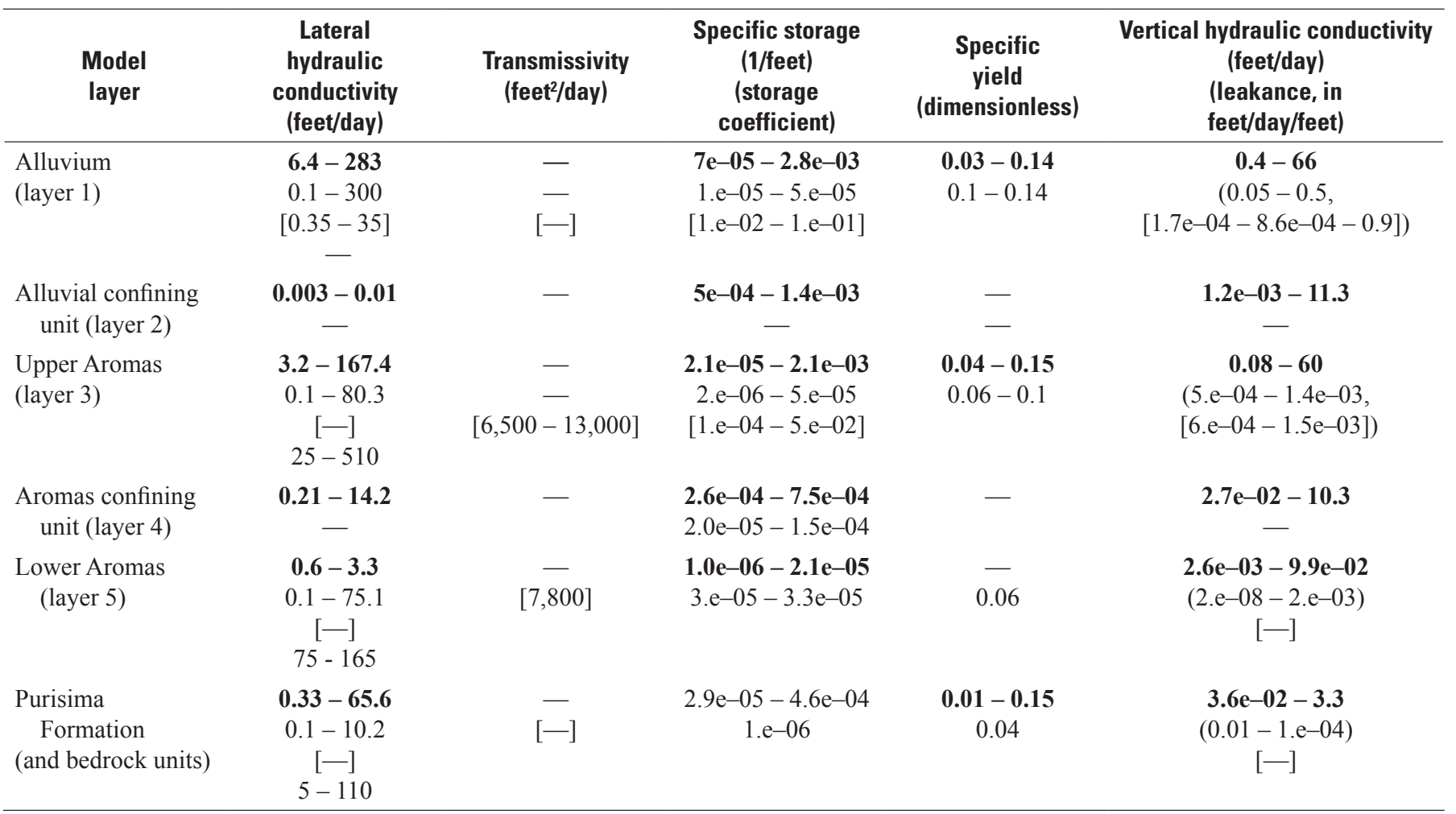

\section{Hydraulic Conductivity of Lithologic End Members}

The lithologic end-member hydraulic conductivities used in this study are $K_{c}$ and $K_{f}$, as defined in the "Texture Analysis" section of this report. Parameter estimation was used, in combination with the texture model developed for the region on the basis of the known stratigraphic units and kriged subsurface texture based on reported lithology, to estimate these end-member $\mathrm{K}$ values. These end members were used to estimate the horizontal and vertical conductivities for each cell in the model. The values of hydraulic conductivity are then related to zonal subareas (table 12) that are used to estimate final values derived from model calibration. The final parameters from model calibration representing hydraulic properties and related scale factors are included in the summary of parameter values in table 13 discussed in the section "Calibration to Measured Water Levels, Streamflows, and Pumpage." Final values of hydraulic properties that include these various scale factors are summarized in table 11.
The hydrostratigraphic layers of the aquifer systems in Pajaro Valley have somewhat different depositional environments and textural compositions that affect the end-member $\mathrm{K}$ values. Allowing for the adjustment of end-member $\mathrm{K}$ values (and related scale factors) by subarea enables the calibration process to account for spatial variability in hydraulic properties owing to differences in depositional environments and textural compositions. Each of the hydrostratigraphic model layers was subdivided into subareas to allow for spatial variability in hydraulic properties within layers (table 12, fig. 27). Parts of the confining units where they were estimated to be missing are represented by "phantom" subregions with hydraulic properties that allow communication between surrounding layers; the assigned thickness of phantom subregions was $16.4 \mathrm{ft}(5 \mathrm{~m})$. All layers have a separate zone for the offshore region where the geostatisitical estimates were extrapolated, and are therefore more uncertain. 
Table 12. Summary of parameter zones and related property parameter names used to calibrate horizontal hydraulic conductivity $\left(\mathrm{K}_{H}\right)$, vertical hydraulic conductivity $\left(\mathrm{K}_{v}\right)$, and specific storage and specific yield (SS) in the Pajaro Valley hydrologic model (PVHM), Pajaro Valley, California.

$[\%$, percent; <, less than; >, greater than $]$

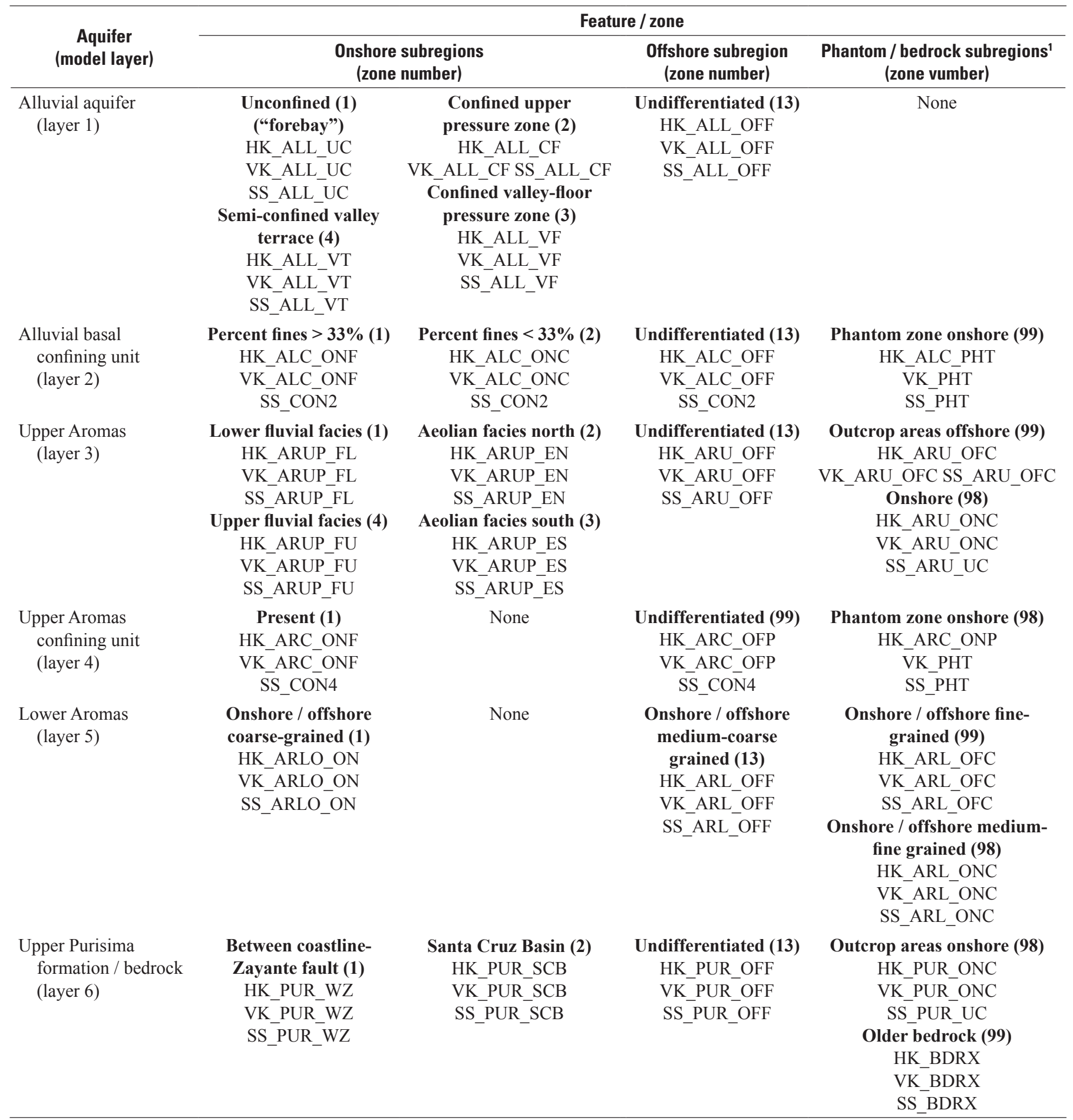

${ }^{1}$ Phantom zones within a model layer are groups of cells within the interior active parts of a specific model layer where the geohydrologic unit is missing and an assumed thickness of 5 meters is used. 
Table 13. Summary of parameter values and sentivities estimated for the Pajaro Valley hydrologic model (PVHM), Pajaro Valley, California.

\begin{tabular}{|c|c|c|c|c|c|c|c|}
\hline $\begin{array}{l}\text { Parameter } \\
\text { type } \\
\text { [model } \\
\text { layers] }\end{array}$ & $\begin{array}{l}\text { Parameter } \\
\text { name }\end{array}$ & $\begin{array}{l}\text { Parameter } \\
\text { description }\end{array}$ & Value & Units $^{1}$ & $\begin{array}{l}\text { Estimated } \\
\text { using } \\
\text { automated } \\
\text { methods } \\
\end{array}$ & $\begin{array}{l}\text { Rank and } \\
\text { composite } \\
\text { scaled } \\
\text { sensitivity }{ }^{1} \\
\end{array}$ & $\begin{array}{l}\text { Package / } \\
\text { process- } \\
\text { parameter } \\
\text { group }\end{array}$ \\
\hline$[1,3,6]$ & $\begin{array}{l}\text { Dry seasons } \\
\text { SCL_KCSDFL } \\
\text { SCL_KCSDWN } \\
\text { SCL_KCSDSP } \\
\text { SCL_KCSDSU } \\
\text { Wet seasons } \\
\text { SCL_KCSWFL } \\
\text { SCL_KCSWWN } \\
\text { SCL_KCSWSP } \\
\text { SCL_KCSWSU }\end{array}$ & $\begin{array}{l}\text { Stress coefficient for } \\
\text { early (1963-92) } \\
\text { agriculture crop } \\
\text { coefficients }\end{array}$ & $\begin{array}{l}1.05 \\
1.05 \\
1.05 \\
1.25 \\
- \\
0.85 \\
0.80 \\
0.80 \\
0.95\end{array}$ & multiplier & no & $\begin{array}{c}27 / 1.66 \\
19 / 2.79 \\
12 / 5.30 \\
4 / 7.89 \\
- \\
38 / 1.08 \\
24 / 2.00 \\
18 / 2.97 \\
15 / 4.65\end{array}$ & $\begin{array}{l}\text { FMP2 - Kc- } \\
\text { properties }\end{array}$ \\
\hline$[1,3,6]$ & $\begin{array}{l}\text { Winter (December-April) } \\
\text { Precipitation factor } \\
\text { Wet-winters } \\
\text { PRECIP_MTLWWN } \\
\text { Dry-winters } \\
\text { PRECIP_MLT_DWN } \\
\text { PRECIP_MLT }\end{array}$ & $\begin{array}{l}\text { Multiplier for winter } \\
\text { precipitation } \\
\text { to account for } \\
\text { fraction of total } \\
\text { precipitation } \\
\text { available for } \\
\text { consumptive use } \\
\text { and recharge }\end{array}$ & $\begin{array}{l}3.28 \mathrm{e}-05 \\
3.28 \mathrm{e}-05 \\
3.28 \mathrm{e}-05\end{array}$ & $\begin{array}{l}\text { multiplier- } \\
\text { units } \\
\text { conversion }\end{array}$ & no & $\begin{array}{c}2 / 12.00 \\
3 / 11.63 \\
8 / 7.23\end{array}$ & $\begin{array}{l}\text { FMP2 - } \\
\quad \text { precipitation }\end{array}$ \\
\hline
\end{tabular}


Table 13. Summary of parameter values and sentivities estimated for the Pajaro Valley hydrologic model (PVHM), Pajaro Valley, California.-Continued

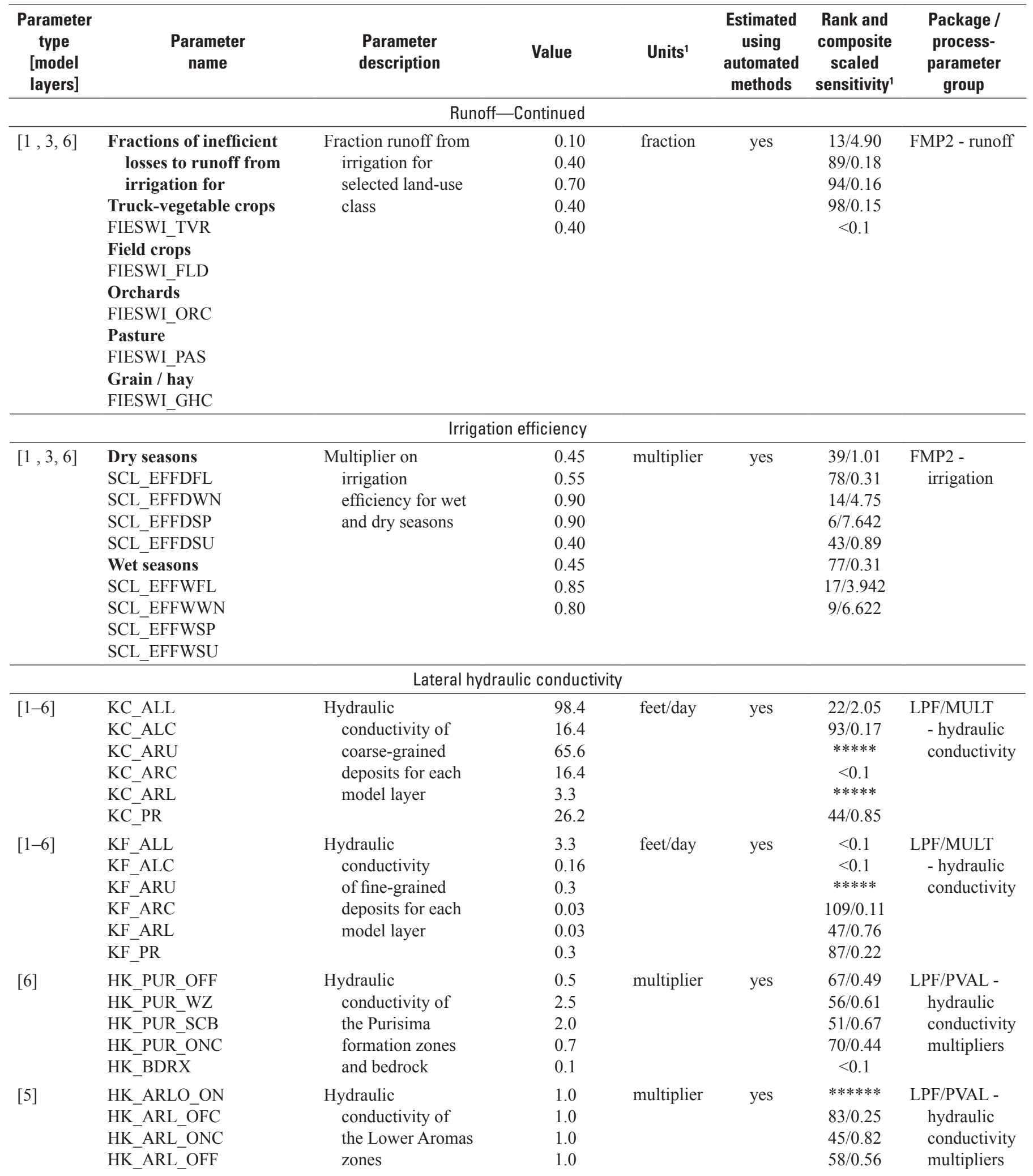


Table 13. Summary of parameter values and sentivities estimated for the Pajaro Valley hydrologic model (PVHM), Pajaro Valley, California.-Continued

\begin{tabular}{|c|c|c|c|c|c|c|c|}
\hline $\begin{array}{l}\text { Parameter } \\
\text { type } \\
\text { [model } \\
\text { layers] }\end{array}$ & $\begin{array}{l}\text { Parameter } \\
\text { name }\end{array}$ & $\begin{array}{l}\text { Parameter } \\
\text { description }\end{array}$ & Value & Units $^{1}$ & $\begin{array}{l}\text { Estimated } \\
\text { using } \\
\text { automated } \\
\text { methods }\end{array}$ & $\begin{array}{l}\text { Rank and } \\
\text { composite } \\
\text { scaled } \\
\text { sensitivity }\end{array}$ & $\begin{array}{l}\text { Package / } \\
\text { process- } \\
\text { parameter } \\
\text { group }\end{array}$ \\
\hline \multicolumn{8}{|c|}{ Lateral hydraulic conductivity-Continued } \\
\hline [4] & $\begin{array}{l}\text { HK_ARC_ONF } \\
\text { HK_ARC_ONC } \\
\text { HK_ARC_OFP } \\
\text { HK_ARC_OND }\end{array}$ & $\begin{array}{l}\text { Hydraulic } \\
\text { conductivity of the } \\
\text { Aromas confining } \\
\text { zones }\end{array}$ & $\begin{array}{l}0.1 \\
0.0001 \\
1 . e-10 \\
1 . e-10\end{array}$ & multiplier & yes & $\begin{array}{c}<0.1 \\
<0.1 \\
108 / 0.11 \\
<0.1\end{array}$ & $\begin{array}{l}\text { LPF/PVAL - } \\
\text { hydraulic } \\
\text { conductivity } \\
\text { multipliers }\end{array}$ \\
\hline$[3]$ & $\begin{array}{l}\text { HK_ARUP_FU } \\
\text { HK_ARUP_FL } \\
\text { HK_ARUP_EN } \\
\text { HK_ARUP_ES } \\
\text { HK_ARU_OFC } \\
\text { HK_ARU_ONC } \\
\text { HK_ARU_OFF }\end{array}$ & $\begin{array}{l}\text { Hydraulic } \\
\text { conductivity of } \\
\text { the Upper Aromas } \\
\text { zones }\end{array}$ & $\begin{array}{l}2.1 \\
0.1 \\
3.0 \\
3.0 \\
1.0 \\
2.0 \\
0.01\end{array}$ & multiplier & yes & $\begin{array}{c}65 / 0.49 \\
* * * * * \\
<0.1 \\
57 / 0.59 \\
85 / 0.22 \\
81 / 0.28 \\
72 / 0.41\end{array}$ & $\begin{array}{l}\text { LPF/PVAL - } \\
\text { hydraulic } \\
\text { conductivity } \\
\text { multipliers }\end{array}$ \\
\hline$[1]$ & $\begin{array}{l}\text { HK_ALL_UC } \\
\text { HK_ALL_CF } \\
\text { HK_ALL_VT } \\
\text { HK_ALL_VF } \\
\text { HK_ALL_OFF }\end{array}$ & $\begin{array}{l}\text { Hydraulic } \\
\text { conductivity of the } \\
\text { Alluvial zones }\end{array}$ & $\begin{array}{l}3.8 \\
0.2 \\
3.6 \\
0.3 \\
3.0\end{array}$ & multiplier & yes & $\begin{array}{c}30 / 1.46 \\
110 / 0.11 \\
59 / 0.54 \\
46 / 0.79 \\
111 / 0.10 \\
\end{array}$ & $\begin{array}{l}\text { LPF/PVAL - } \\
\text { hydraulic } \\
\text { conductivity } \\
\text { multipliers }\end{array}$ \\
\hline \multicolumn{8}{|c|}{ Vertical hydraulic conductivity } \\
\hline$[6]$ & $\begin{array}{l}\text { VK_BDRX } \\
\text { VK_PUR_OFF } \\
\text { VK_PUR_WZ } \\
\text { VK_PUR_SCB } \\
\text { VK_PUR_ONC }\end{array}$ & $\begin{array}{l}\text { Hydraulic } \\
\text { conductivity of } \\
\text { the Purisima } \\
\text { formation zones } \\
\text { and bedrock }\end{array}$ & $\begin{array}{l}1.0 \\
0.1 \\
0.1 \\
0.1 \\
1.0\end{array}$ & multiplier & no & $\begin{array}{l}<0.1 \\
<0.1 \\
<0.1 \\
<0.1 \\
<0.1\end{array}$ & $\begin{array}{l}\text { LPF/PVAL - } \\
\text { hydraulic } \\
\text { conductivity } \\
\text { multipliers }\end{array}$ \\
\hline [4] & $\begin{array}{l}\text { VK_ARC_ONF } \\
\text { VK_ARC_ONP } \\
\text { VK_ARC_OFP }\end{array}$ & $\begin{array}{l}\text { Hydraulic } \\
\text { conductivity of the } \\
\text { Aromas confining } \\
\text { zones }\end{array}$ & $\begin{array}{l}0.5 \\
10.0 \\
5.0\end{array}$ & multiplier & no & $<0.1$ & $\begin{array}{l}\text { LPF/PVAL - } \\
\text { hydraulic } \\
\text { conductivity } \\
\text { multipliers }\end{array}$ \\
\hline$[3]$ & $\begin{array}{l}\text { VK_ARUP_FU } \\
\text { VK_ARUP_FL } \\
\text { VK_ARUP_EN } \\
\text { VK_ARUP_ES } \\
\text { VK_ARU_OFC } \\
\text { VK_ARU_ONC } \\
\text { VK_ARU_OFF }\end{array}$ & $\begin{array}{l}\text { Hydraulic } \\
\text { conductivity of } \\
\text { the Upper Aromas } \\
\text { zones }\end{array}$ & $\begin{array}{l}0.5 \\
0.1 \\
5.0 \\
5.0 \\
5.0 \\
20.0 \\
0.01\end{array}$ & multiplier & yes & $\begin{array}{c}103 / 0.12 \\
52 / 0.66 \\
<0.1 \\
<0.1 \\
<0.1 \\
106 / 0.11 \\
99 / 0.15\end{array}$ & $\begin{array}{l}\text { LPF/PVAL - } \\
\text { hydraulic } \\
\text { conductivity } \\
\text { multipliers }\end{array}$ \\
\hline$[2]$ & $\begin{array}{l}\text { VK_ALC_ONF } \\
\text { VK_ALC_ONC } \\
\text { VK_ALC_OFF } \\
\text { VK_PHT }\end{array}$ & $\begin{array}{l}\text { Hydraulic } \\
\text { conductivity of the } \\
\text { Alluvial confining } \\
\text { zones }\end{array}$ & $\begin{array}{l}5 . \mathrm{e}-03 \\
5.0 \\
0.1 \\
1.0 \mathrm{e}-03\end{array}$ & multiplier & yes & $\begin{array}{c}100 / 0.14 \\
<0.1 \\
<0.1 \\
84 / 0.24\end{array}$ & $\begin{array}{l}\text { LPF/PVAL - } \\
\text { hydraulic } \\
\text { conductivity } \\
\text { multipliers }\end{array}$ \\
\hline
\end{tabular}


Table 13. Summary of parameter values and sentivities estimated for the Pajaro Valley hydrologic model (PVHM), Pajaro Valley, California.-Continued

\begin{tabular}{|c|c|c|c|c|c|c|c|}
\hline $\begin{array}{l}\text { Parameter } \\
\text { type } \\
\text { [model } \\
\text { layers] }\end{array}$ & $\begin{array}{l}\text { Parameter } \\
\text { name }\end{array}$ & $\begin{array}{l}\text { Parameter } \\
\text { description }\end{array}$ & Value & Units $^{1}$ & $\begin{array}{l}\text { Estimated } \\
\text { using } \\
\text { automated } \\
\text { methods }\end{array}$ & $\begin{array}{l}\text { Rank and } \\
\text { composite } \\
\text { scaled } \\
\text { sensitivity }{ }^{1}\end{array}$ & $\begin{array}{l}\text { Package / } \\
\text { process- } \\
\text { parameter } \\
\text { group }\end{array}$ \\
\hline [1] & $\begin{array}{l}\text { VK_ALL_UC } \\
\text { VK_ALL_CF } \\
\text { VK_ALL_VT } \\
\text { VK_ALL_VF } \\
\text { VK_ALL_OFF }\end{array}$ & $\begin{array}{l}\text { Hydraulic } \\
\text { conductivity of the } \\
\text { Alluvial zones }\end{array}$ & $\begin{array}{l}5.0 \\
0.1 \\
5.0 \\
0.1 \\
1.0\end{array}$ & multiplier & yes & $\begin{array}{l}<0.1 \\
<0.1 \\
<0.1 \\
<0.1 \\
<0.1\end{array}$ & $\begin{array}{l}\text { LPF/PVAL - } \\
\text { hydraulic } \\
\text { conductivity } \\
\text { multipliers }\end{array}$ \\
\hline \multicolumn{8}{|c|}{ Storage properties } \\
\hline$[1-3]$ & SSKECA & $\begin{array}{l}\text { Skeletal elastic } \\
\text { specific storage } \\
\text { of coarse-grained } \\
\text { terrestrial deposits } \\
\text { of alluvium and } \\
\text { Upper Aromas }\end{array}$ & $5.0 \mathrm{e}-06$ & $1 /$ foot & no & $<0.1$ & $\begin{array}{l}\text { LPF/MULT } \\
\text { - storage } \\
\text { properties }\end{array}$ \\
\hline$[1-3]$ & SSKEFA & $\begin{array}{l}\text { Skeletal elastic } \\
\text { specific storage } \\
\text { of fine-grained } \\
\text { terrestrial deposits } \\
\text { of Alluvium and } \\
\text { Upper Aromas }\end{array}$ & $5.0 \mathrm{e}-05$ & $1 /$ foot & no & $79 / 0.29$ & $\begin{array}{l}\text { LPF/MULT } \\
\text { - storage } \\
\text { properties }\end{array}$ \\
\hline [4-6] & SSKECM & $\begin{array}{l}\text { Skeletal elastic } \\
\text { specific storage } \\
\text { of coarse-grained } \\
\text { marine deposits } \\
\text { of Lower Aromas } \\
\text { and Purisima }\end{array}$ & $5.0 \mathrm{e}-06$ & $1 /$ foot & no & $73 / 0.36$ & $\begin{array}{l}\text { LPF/MULT } \\
\text { - storage } \\
\text { properties }\end{array}$ \\
\hline$[1-3]$ & PHI_CRS & $\begin{array}{l}\text { Porosity of the } \\
\text { coarse-grained } \\
\text { Alluvial deposits }\end{array}$ & 35 & percentage & no & $<0.1$ & $\begin{array}{l}\text { LPF/MULT } \\
\text { - storage } \\
\text { properties }\end{array}$ \\
\hline$[1-3]$ & PHI_FIN & $\begin{array}{l}\text { Porosity of the fine- } \\
\text { grained Alluvial } \\
\text { deposits }\end{array}$ & 40 & percentage & no & $101 / 0.14$ & $\begin{array}{l}\text { LPF/MULT } \\
\text { - storage } \\
\text { properties }\end{array}$ \\
\hline [4-6] & PHI_CRS_ARU & $\begin{array}{l}\text { Porosity of the } \\
\text { coarse-grained } \\
\text { marine deposits }\end{array}$ & 20 & percentage & no & $69 / 0.48$ & $\begin{array}{l}\text { LPF/MULT } \\
\text { - storage } \\
\text { properties }\end{array}$ \\
\hline$[4-6]$ & PHI_FIN_ARU & $\begin{array}{l}\text { Porosity of the fine- } \\
\text { grained marine } \\
\text { deposits }\end{array}$ & 25 & percentage & no & $<0.1$ & $\begin{array}{l}\text { LPF/MULT } \\
\text { - storage } \\
\text { properties }\end{array}$ \\
\hline [1] & SY1_FAC & $\begin{array}{l}\text { Specific yield of } \\
\text { Alluvial deposits }\end{array}$ & 0.20 & fraction & no & $<0.1$ & $\begin{array}{l}\text { LPF/MULT } \\
\text { - storage } \\
\text { properties }\end{array}$ \\
\hline [3] & SY3_FAC & $\begin{array}{l}\text { Specific yield of } \\
\text { Upper Aromas } \\
\text { deposits }\end{array}$ & 0.15 & fraction & no & $<0.1$ & $\begin{array}{l}\text { LPF/MULT } \\
\text { - storage } \\
\text { properties }\end{array}$ \\
\hline
\end{tabular}


Table 13. Summary of parameter values and sentivities estimated for the Pajaro Valley hydrologic model (PVHM), Pajaro Valley, California.-Continued

\begin{tabular}{|c|c|c|c|c|c|c|c|}
\hline $\begin{array}{c}\text { Parameter } \\
\text { type } \\
\text { [model } \\
\text { layers] }\end{array}$ & $\begin{array}{l}\text { Parameter } \\
\text { name }\end{array}$ & $\begin{array}{l}\text { Parameter } \\
\text { description }\end{array}$ & Value & Units $^{1}$ & $\begin{array}{l}\text { Estimated } \\
\text { using } \\
\text { automated } \\
\text { methods }\end{array}$ & $\begin{array}{l}\text { Rank and } \\
\text { composite } \\
\text { scaled } \\
\text { sensitivity }\end{array}$ & $\begin{array}{c}\text { Package / } \\
\text { process- } \\
\text { parameter } \\
\text { group }\end{array}$ \\
\hline$[6]$ & SY6_FAC & $\begin{array}{l}\text { Specific yield } \\
\text { of Purisima } \\
\text { formation }\end{array}$ & 0.10 & fraction & no & $<0.1$ & $\begin{array}{c}\text { LPF/MULT } \\
\text { - storage } \\
\text { properties }\end{array}$ \\
\hline$[5]$ & $\begin{array}{l}\text { SS_ARLO_ON } \\
\text { SS_ARL_ONC } \\
\text { SS_ARL_OFF } \\
\text { SS_ARL_OFC }\end{array}$ & $\begin{array}{l}\text { Specific storage of } \\
\text { Lower Aromas } \\
\text { zones }\end{array}$ & $\begin{array}{l}0.15 \\
0.01 \\
0.01 \\
0.15\end{array}$ & multiplier & no & $\begin{array}{c}75 / 0.34 \\
<0.1 \\
31 / 1.44 \\
90 / 0.18\end{array}$ & $\begin{array}{c}\text { LPF/PVAL } \\
\text { - storage } \\
\text { properties }\end{array}$ \\
\hline$[4]$ & SS_CON4 & $\begin{array}{l}\text { Specific storage of } \\
\text { Aromas confining } \\
\text { zones }\end{array}$ & 5.0 & multiplier & no & $34 / 1.16$ & $\begin{array}{l}\text { LPF/PVAL } \\
\text { - storage } \\
\text { properties }\end{array}$ \\
\hline$[3]$ & $\begin{array}{l}\text { SS_ARUP_FU } \\
\text { SS_ARUP_FL } \\
\text { SS_ARUP_EN } \\
\text { SS_ARUP_ES } \\
\text { SS_ARU_OFC } \\
\text { SS_ARUP_UC } \\
\text { SS_ARU_OFF }\end{array}$ & $\begin{array}{l}\text { Specific storage of } \\
\text { Upper Aromas } \\
\text { zones }\end{array}$ & $\begin{array}{l}0.5 \\
0.5 \\
1.0 \\
0.7 \\
2.0 \\
1.2 \\
1.0\end{array}$ & multiplier & no & $\begin{array}{c}107 / 0.11 \\
<0.1 \\
<0.1 \\
92 / 0.17 \\
66 / 0.49 \\
<0.1 \\
<0.1\end{array}$ & $\begin{array}{l}\text { LPF/PVAL } \\
\text { - storage } \\
\text { properties }\end{array}$ \\
\hline [2] & SS_CON2 & $\begin{array}{l}\text { Specific storage of } \\
\text { Alluvial confining } \\
\text { zones }\end{array}$ & 5.0 & multiplier & no & $<0.1$ & $\begin{array}{l}\text { LPF/PVAL } \\
\text { - storage } \\
\text { properties }\end{array}$ \\
\hline \multicolumn{8}{|c|}{ SKIN factor for multi-node wells } \\
\hline$[6]$ & SKIN_MNW6 & $\begin{array}{l}\text { Skin factor for } \\
\text { Purisima } \\
\text { formation layer }\end{array}$ & 68.0 & multiplier & no & $102 / 0.13$ & $\begin{array}{l}\text { MNW } \\
\text { property }\end{array}$ \\
\hline [5] & SKIN_MNW5 & $\begin{array}{l}\text { Skin factor for } \\
\text { Lower Aromas } \\
\text { layer }\end{array}$ & 58.0 & multiplier & no & $104 / 0.12$ & $\begin{array}{l}\text { MNW } \\
\text { property }\end{array}$ \\
\hline [4] & SKIN_MNW4 & $\begin{array}{l}\text { Skin factor for } \\
\text { Aromas confining } \\
\text { layer }\end{array}$ & 36.0 & multiplier & no & $<0.1$ & $\begin{array}{l}\text { MNW } \\
\text { property }\end{array}$ \\
\hline$[3]$ & SKIN_MNW3 & $\begin{array}{l}\text { Skin factor for Upper } \\
\text { Aromas layer }\end{array}$ & 32.0 & multiplier & no & $97 / 0.16$ & $\begin{array}{l}\text { MNW } \\
\text { property }\end{array}$ \\
\hline [2] & SKIN_MNW2 & $\begin{array}{l}\text { Skin factor for } \\
\text { Alluvial confining } \\
\text { layer }\end{array}$ & 36.0 & multiplier & no & $<0.1$ & $\begin{array}{l}\text { MNW } \\
\text { property }\end{array}$ \\
\hline$[1]$ & SKIN_MNW1 & $\begin{array}{l}\text { Skin factor for } \\
\text { Alluvial layer }\end{array}$ & 35.0 & multiplier & no & $<0.1$ & $\begin{array}{l}\text { MNW } \\
\text { property }\end{array}$ \\
\hline
\end{tabular}


Table 13. Summary of parameter values and sentivities estimated for the Pajaro Valley hydrologic model (PVHM), Pajaro Valley, California.-Continued

\begin{tabular}{|c|c|c|c|c|c|c|c|}
\hline $\begin{array}{c}\text { Parameter } \\
\text { type } \\
\text { [model } \\
\text { layers] }\end{array}$ & $\begin{array}{l}\text { Parameter } \\
\text { name }\end{array}$ & $\begin{array}{l}\text { Parameter } \\
\text { description }\end{array}$ & Value & Units $^{1}$ & $\begin{array}{l}\text { Estimated } \\
\text { using } \\
\text { automated } \\
\text { methods }\end{array}$ & $\begin{array}{l}\text { Rank and } \\
\text { composite } \\
\text { scaled } \\
\text { sensitivity' }\end{array}$ & $\begin{array}{l}\text { Package / } \\
\text { process- } \\
\text { parameter } \\
\text { group }\end{array}$ \\
\hline [6] & $\begin{array}{l}\text { GHBSCA1A_6 } \\
\text { GHB233H1_6 } \\
\text { GHB_12D1_6 } \\
\text { GHB_16D1_6 } \\
\text { GHBCWDBE_6 } \\
\text { GHBCWD12_6 } \\
\text { GHBCWDBW_6 }\end{array}$ & $\begin{array}{l}\text { Multiplier for } \\
\text { Purisima GHB } \\
\text { cells }\end{array}$ & $\begin{array}{l}2.2 \mathrm{e}-02 \\
1.0 \mathrm{e}-05 \\
1.0 \mathrm{e}-06 \\
1.0 \mathrm{e}-06 \\
1.0 \mathrm{e}-06 \\
1.0 \mathrm{e}-06 \\
1.0 \mathrm{e}-06\end{array}$ & multiplier & no & $\begin{array}{l}63 / 0.50 \\
<0.1 \\
<0.1 \\
<0.1 \\
<0.1 \\
<0.1 \\
<0.1\end{array}$ & $\begin{array}{l}\text { GHB/PVAL } \\
\text { - hydraulic } \\
\text { conductance }\end{array}$ \\
\hline [5] & & $\begin{array}{l}\text { Multiplier for Lower } \\
\text { Aromas GHB } \\
\text { cells }\end{array}$ & $\begin{array}{l}2.0 \mathrm{e}-00 \\
2.5 \mathrm{e}-00 \\
1.8 \mathrm{e}-02 \\
1.0 \mathrm{e}-02 \\
2.0 \mathrm{e}-00 \\
1.0 \mathrm{e}-06 \\
1.0 \mathrm{e}-01 \\
1.0 \mathrm{e}-00\end{array}$ & multiplier & no & $\begin{array}{c}<0.1 \\
82 / 0.26 \\
<0.1 \\
<0.1 \\
96 / 0.15 \\
<0.1 \\
<0.1 \\
<0.1\end{array}$ & $\begin{array}{l}\text { GHB/PVAL } \\
\text { - hydraulic } \\
\text { conductance }\end{array}$ \\
\hline$[3]$ & $\begin{array}{l}\text { GHB_CC51_3 } \\
\text { GHB_4L1_3 } \\
\text { GHB333H1_3 } \\
\text { GHB233H1_3 } \\
\text { GHB_12D1_3 } \\
\text { GHB_16D1_3 } \\
\text { GHB_CWD3_3 } \\
\text { GHBCWD10_3 }\end{array}$ & $\begin{array}{l}\text { Multiplier for Upper } \\
\text { Aromas GHB } \\
\text { cells }\end{array}$ & $\begin{array}{l}0.5 \\
1.0 \mathrm{e}-05 \\
1.0 \mathrm{e}-06 \\
1.0 \mathrm{e}-05 \\
1.0 \mathrm{e}-05 \\
1.0 \mathrm{e}-05 \\
1.0 \mathrm{e}-04 \\
1.0 \mathrm{e}-04\end{array}$ & multiplier & no & $\begin{array}{c}97 / 0.15 \\
<0.1 \\
<0.1 \\
<0.1 \\
<0.1 \\
<0.1 \\
<0.1 \\
<0.1\end{array}$ & $\begin{array}{l}\text { GHB/PVAL } \\
\text { - hydraulic } \\
\text { conductance }\end{array}$ \\
\hline$[1]$ & GHB_MWA_1 & $\begin{array}{l}\text { Multiplier for } \\
\text { Alluvium GHB } \\
\text { cells }\end{array}$ & $1.0 \mathrm{e}-05$ & multiplier & no & $<0.1$ & $\begin{array}{l}\text { GHB/PVAL } \\
\text { - hydraulic } \\
\text { conductance }\end{array}$ \\
\hline \multicolumn{8}{|c|}{ Offshore General-Head Boundary conductance (GHB) } \\
\hline$[3]$ & $\begin{array}{l}\text { Nearshore Shelf Outcrop } \\
\text { ghbLY3_1V } \\
\text { Northern Boundary } \\
\text { ghbLY3_2L } \\
\text { Southern Boundary } \\
\text { ghbLY3_4V }\end{array}$ & Upper Aromas & $\begin{array}{l}328.0 \\
0.03 \\
0.003\end{array}$ & $\mathrm{ft}^{2} /$ day & $\begin{array}{l}\text { yes } \\
\text { no } \\
\text { no }\end{array}$ & $\begin{array}{l}<0.1 \\
<0.1 \\
<0.1\end{array}$ & $\begin{array}{l}\text { GHB - } \\
\text { hydraulic } \\
\text { conductance }\end{array}$ \\
\hline$[5]$ & & Lower Aromas & $\begin{array}{l}0.003 \\
0.0003\end{array}$ & $\mathrm{ft}^{2} /$ day & $\begin{array}{l}\text { no } \\
\text { no }\end{array}$ & $\begin{array}{l}<0.1 \\
<0.1\end{array}$ & $\begin{array}{l}\text { GHB - } \\
\text { hydraulic } \\
\text { conductance }\end{array}$ \\
\hline
\end{tabular}


Table 13. Summary of parameter values and sentivities estimated for the Pajaro Valley hydrologic model (PVHM), Pajaro Valley, California.-Continued

\begin{tabular}{|c|c|c|c|c|c|c|c|}
\hline $\begin{array}{l}\text { Parameter } \\
\text { type } \\
\text { [model } \\
\text { layers] }\end{array}$ & $\begin{array}{l}\text { Parameter } \\
\text { name }\end{array}$ & $\begin{array}{l}\text { Parameter } \\
\text { description }\end{array}$ & Value & Units $^{1}$ & $\begin{array}{l}\text { Estimated } \\
\text { using } \\
\text { automated } \\
\text { methods }\end{array}$ & $\begin{array}{l}\text { Rank and } \\
\text { composite } \\
\text { scaled } \\
\text { sensitivity' }\end{array}$ & $\begin{array}{l}\text { Package / } \\
\text { process- } \\
\text { parameter } \\
\text { group }\end{array}$ \\
\hline \multicolumn{8}{|c|}{ Offshore General-Head Boundary conductance (GHB)_Continued } \\
\hline [6] & $\begin{array}{l}\text { Nearshore Shelf Outcrop } \\
\text { ghbLY6_1V } \\
\text { Northern Boundary } \\
\text { ghbLY6_2L } \\
\text { Southern Boundary } \\
\text { ghbLY6_4V }\end{array}$ & Purisima formation & $\begin{array}{l}0.3 \\
0.0003 \\
0.00003\end{array}$ & $\mathrm{ft}^{2} /$ day & $\begin{array}{l}\text { yes } \\
\text { no } \\
\text { no }\end{array}$ & $\begin{array}{c}61 / 0.53 \\
<0.1 \\
<0.1\end{array}$ & $\begin{array}{l}\text { GHB - } \\
\text { hydraulic } \\
\text { conductance }\end{array}$ \\
\hline \multicolumn{8}{|c|}{ Horizontal flow-barrier conductance } \\
\hline$[6]$ & HFB0001 & $\begin{array}{l}\text { Conductance of } \\
\text { Zayante fault in } \\
\text { Pursima formation }\end{array}$ & $1.7 \mathrm{e}-11$ & $\mathrm{ft}^{2} /$ day & no & $<0.1$ & $\begin{array}{l}\text { HFB/PVAL - } \\
\text { hydraulic } \\
\text { conductance }\end{array}$ \\
\hline
\end{tabular}

${ }^{1}$ Ranks and Scaled sensitivities indicated with '*****' reached upper limit at which point model became unstable and would not converge.

\section{EXPLANATION}

\begin{tabular}{|c|c|c|}
\hline Pajaro River watershed & Model grid boundary \\
Outside Pajaro River \\
watershed
\end{tabular}

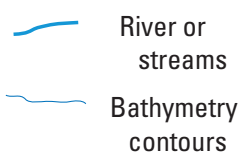

D $\begin{gathered}\text { Upper } \\ \text { Aromas } \\ \text { confining unit }\end{gathered}$

(Layer 4)
Lower
E $\quad \begin{aligned} & \text { Aromas } \\ & \text { (Layer 5) }\end{aligned}$
$\boldsymbol{F} \quad$ Upper Purisima FM/
Bedrock
(Layer 6)
Present (1) Percent fines $>16 \%$
- Phantom zone-Onshore (98)
- Phantom zone-Offshore (99)
- Coarse grained (1)
- Medium-coarse grained (13)
- Northwest medium-fine grained (14)
Medium-fine grained (98)
- Fine grained (99)
- Purisima Fm Coastline-Zayante (1)
- Purisima Fm Santa Cruz Basin (2)
- Purisima Fm-Offshore (13)
- Outcrop areas (98)-Onshore***
- Outcrop areas (99)-Older bedrock
$\square$ Not present

${ }^{* *}$ Offshore (2) not used for SS $\quad{ }^{* * *}$ Onshore (98) not used for VK

Figure 27. Distribution of subareas, or zones, for hydraulic properties for model layers $A, 1 ; B, 2 ; C, 3 ; D, 4 ; E$, 5; and $F, 6$ in the Pajaro Valley, California. 

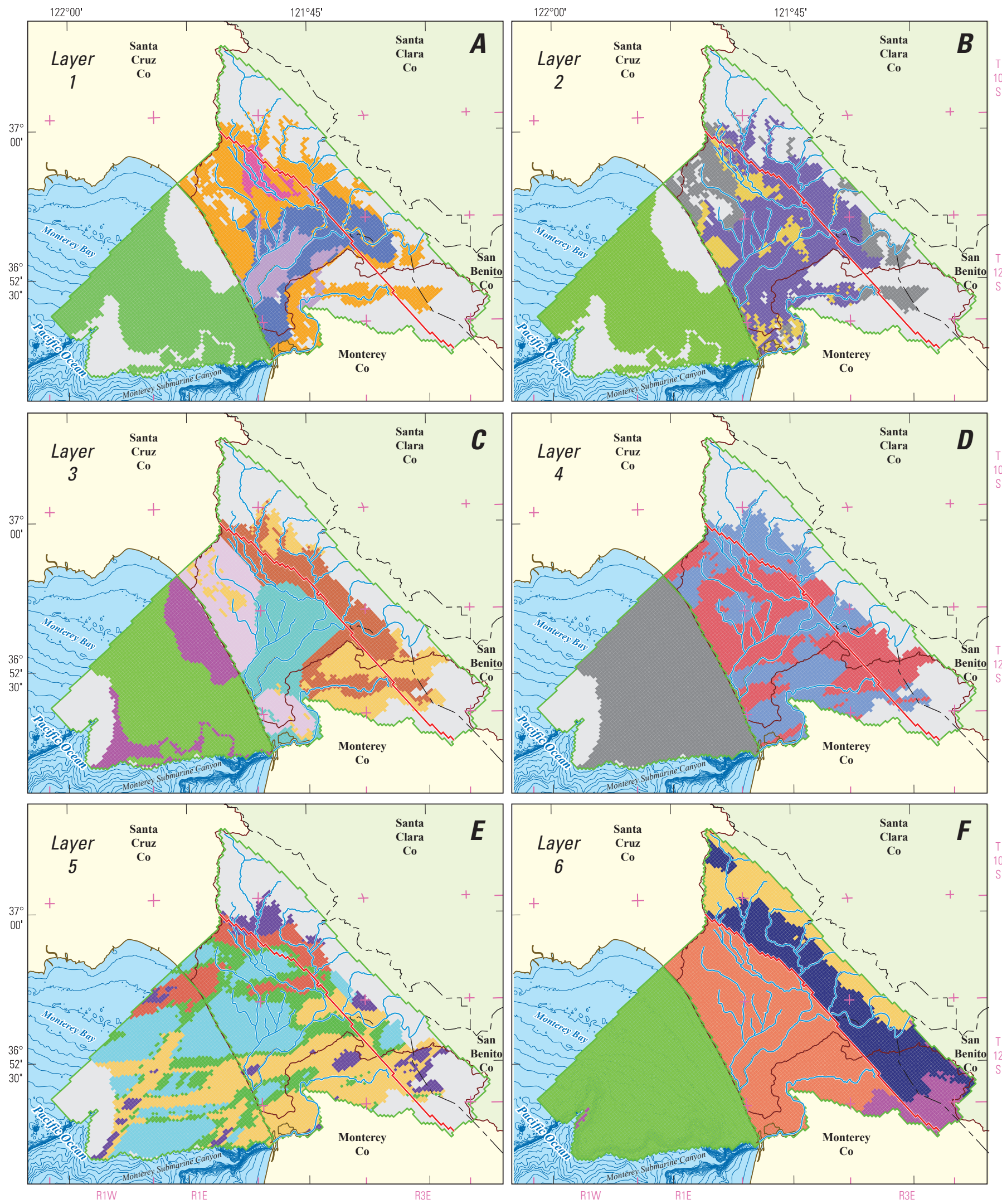

Figure 27. - Continued 
Because the hydraulic properties differ for each of the hydrostratigraphic units, they were estimated separately. The parameters used to control these subareas within each model layer represent offshore areas, outcrop areas, and subareas of confined and unconfined aquifers. In addition, the subareas where the alluvial basal confining unit and the Aromas confining unit are missing are also treated separately and represent regions where the hydraulic properties allow the surrounding units to communicate. Therefore, the hydraulic properties of each of these subareas were estimated with separate model parameters during model calibration (table 12). The calibrated values of $\mathrm{K}_{\mathrm{f}}$ range from $3.3 \mathrm{ft} / \mathrm{d}$ for the Alluvial aquifer layer to $0.03 \mathrm{ft} / \mathrm{d}$ for the Lower Aromas; $\mathrm{K}_{c}$ values range from $98.4 \mathrm{ft} / \mathrm{d}$ for the Alluvial aquifer to $16.4 \mathrm{ft} / \mathrm{d}$ for the sediments of the alluvial and lower Aromas confining layers. For each unit, the distributions of horizontal and vertical $\mathrm{K}$ values vary with the distribution of sediment texture (figs. 24, 25) within each zone of each layer (fig. 27). These values are similar in many parts of the valley to the values tabulated in previous models (Johnson and others, 1988; Teghavi and Smith, 1999d).

Unlike previous models in which the hydraulic conductivity was specified for the confining units below the Alluvial aquifer and below the Upper Aromas, in this study the $\mathrm{K}$ values were delineated for individual units, and were also based on the coarse- and fine-grained end-member values of the hydraulic conductivity. Hydraulic conductivities generally decrease with depth and with increasing distances from the original source of the sediments from adjacent mountain ranges, dune fields, and river channels, which is consistent with the fining downward and fining toward the center sequences observed in the aquifer sediments and textural model. Coarser-grained sediments were simulated near stream channels in the alluvial and Aromas layers (fig. 27A, C) and in the aeolian deposits in the coastal regions of the Upper Aromas. The zones of the lower Aromas were aligned with the textural zones, with the exception of the medium-to-fine grained zone in the Corralitos watershed in the northwestern part of the model that is combined with the fine-grained zone (fig. 27E) By contrast, the Purisima thickness and coarseness was partitioned by the Zayante Fault (fig. 27F), where it is generally coarser grained in the Santa Cruz basin between the Zayante and San Andreas Faults.

\section{Storage Properties}

The hydraulic properties used to simulate the changes in storage of water within the aquifer system consist of three components (Hanson, 1988): specific yield, elastic specific storage, and inelastic specific storage. The first two components, specific yield and the elastic specific storage, represent and govern the reversible uptake and release of water to and from storage. Specific yield represents unconfined storage, which is governed by gravity-driven drainage of the shallow sediments following a decline of the water table. The elastic storage coefficient represents the component of confined storage owing to the compressibility of water and to the reversible compressibility of the matrix or the skeletal framework of the aquifer system (Jacob, 1940; Hanson, 1988). The inelastic storage coefficient governs the irreversible release of water from the inelastic compaction of principally fine-grained deposits, or permanent reduction of pore space, which is associated with land subsidence. However, inelastic storage in fine-grained beds is probably not a significant source of water because of the relatively small water-level declines in the Pajaro Valley. The historical water levels, except for drawdowns near selected supply wells, occur in a range whose lower extent is thought to be above the preconsolidation stress threshold for these aquifersystem sediments and was therefore not included as a feature in this hydrologic model. Separate values of elastic storage for coarse- and fine-grained sediments were used to simulate elastic specific storage that was applied to all layers. Specific yield typically is orders of magnitude larger than specific storage and is volumetrically the dominant storage parameter for the outcrop regions of the alluvium, Upper Aromas, and Purisima.

The Layer Property Flow Package (LPF) was used to define the storage properties in the model. The LPF and multiplier (MULT) packages were used to calculate and specify the storage components that included the compressibility of water for all model layers, the specific yield for the unconfined portions of the uppermost active layers (layers 1, 3, and 6; fig. 3A), and the specific storage (related to the skeletal elastic compressibility of the coarse and finegrained materials). The resulting equation for the composite storage for a model layer is represented as follows:

$$
S^{*}=S+S^{\prime}+S_{y}
$$

where

$S^{*} \quad$ is the total storage of an aquifer layer,

$S \quad$ is the storage of the coarse-grained component,

$S^{\prime} \quad$ is the storage of the fine-grained component, and

$S_{y} \quad$ is the specific yield from the water table drainage for the unconfined portions of an aquifer. 
Both $S$ and $S^{\prime}$ can be further represented by their respective components as follows:

$$
S=b \times S_{s}=\rho g(\alpha+n \beta) \times b
$$

where

$$
\begin{aligned}
& S_{s} \quad \text { is the specific storage, } \\
& p g \text { is the weight of water, } \\
& \alpha \quad \text { is the elastic compressibility of the matrix } \\
& \text { (skeletal) material, } \\
& n \quad \text { is the porosity of the coarse- and fine-grained } \\
& \text { material, } \\
& b \quad \text { is the total thickness of the coarse- and fine- } \\
& \text { grained material, and } \\
& \beta \quad \text { is the compressibility of water. }
\end{aligned}
$$

$S_{s}$ for each model layer on a cell-by-cell basis can be further subdivided into its components for coarse and finegrained material resulting in a complete equation of storage based on textural fractions, total porosity and matrix elastic compressibility as follows:

$$
S_{s}=S_{s F C}+S_{s F f}=\rho g\left[\left(\alpha_{F c}+n_{F c} \beta\right) \times F_{c, i}+\left(\alpha_{F f}+n_{F f} \beta\right) \times F_{f, i}\right](7)
$$

where

total porosity, $n_{T}=n_{F c}+n_{F p}$ is the sum of the coarse and finegrained fractions of porosity, with $n_{F c}=$ $n_{F c} \times F_{c, i}$ and $n_{F f}=n_{F f} \times F_{f, i}$

$\alpha_{F c}$ and $\alpha_{F f}$ are the elastic compressibility of the coarse or fine-grained matrix (skeletal) material, respectively,

$F_{c, i} \quad$ is the fraction of coarse-grained sediment in the $i^{\text {th }}$ cell, and

$F_{f, i} \quad$ is the fraction of fine-grained sediment in the $i^{\text {th }}$ cell, equal to $\left(1-F_{c, i}\right)$.

Although all model layers are simulated as confined, the uppermost active model cells represent unconfined conditions, and are therefore assigned a specific yield. Specific yield, which is a function of sediment porosity and moistureretention characteristics, cannot exceed sediment porosity. The zones used to specify the subareas of the storage properties are similar to those used for the other hydraulic properties (table 12, fig. 26), except for the unconfined subareas of the uppermost layers. The higher end of the range of of specific storage for the alluvium, alluvial and Aromas confining layers (table 11) are beyond the typical range of elastic skeletal compressibilities and may also represent some inelastic compaction, uncertainties in fine-grained thicknesses, or calibration requirements to reduce the amplitude of seasonal variations of groundwater levels.
The compressibility of water as well as the aquifer skeletal elastic compressibilities are dependent on the specified porosities for the coarse- and fine-grained fractions of each hydrostratigraphic unit (model layer). Porosity ranges from 25 to 45 percent in the Purisima Formation on the basis of estimates from sonic logs of the Purisima Formation at Marina (Hanson and others, 2002). The estimated total porosities from selected core samples of alluvial sediments in nearby Santa Clara Valley ranged from 23 to 43 percent, and the effective porosity ranged from 22 to 40 percent in laboratory tests of selected cores (Newhouse and others, 2004). For this model, porosity values range from 20 percent for the coarse-grained Aromas marine deposits to 40 percent for the fine-grained alluvial deposits (table 13). The products of these porosity values and the respective cell-by-cell average coarse- and fine-grained fractional aggregate thicknesses are summed and multiplied by the compressibility of water $\left(1.4 \times 10^{-6} \mathrm{ft}^{-1}\right)$ to yield a value of specific storage for water for each active cell of every layer.

For the uppermost active cells, specific yield divided by aquifer thickness was added to the specific storage values. Specific yield was calculated using a linear relation between the fraction of coarse grained deposits, between 0 and 1 , and an upper specific yield values ranging from 0.3 for the alluvial deposits to 0.1 for the Purisima Formation (table 13). During calibration, a multiplier was used for each zone, and the final range in specific yield of 0.08 for the alluvium, 0.11 for the upper and lower Aromas, and 0.06 for the Purisima Formation (fig. 27, tables 12,13).

\section{Hydrogeologic Structures}

The only fault structures included in the PVHM are simplifications of the San Andreas and the Zayante Faults. The San Andreas Fault forms the eastern no-flow boundary of the model and edge of the active groundwater flow region along the foothills of the headlands of the Santa Cruz Mountains (figs. 3A,C). The Zayante Fault, as described by Dupre (1975), is the bounding fault of the inland structural subbasin called the Santa Cruz Basin (figs. 3A, C). This fault was used to delineate a potential partial hydrologic flow barrier within the Purisima Formation based on the gravity maps and earthquake analysis of Jachens (2006) and a recent bedrock subsurface map (Michael Cloud, Santa Cruz County Environmental Department, written commun., 2007). The Horizontal Flow Barrier Package (Hsieh and Freckelton, 1993) was used to simulate resistance to flow across the Zayante Fault in the Purisima Formation (fig. 3A). The effectiveness of this fault as a partial flow barrier was estimated by a parameter representing the conductance of the vertical model cell faces aligned with the fault trace (table 13). 


\section{Initial Conditions}

For transient models, initial conditions define the system state at the beginning of the simulation. There is a long history of groundwater development and irrigation in the study area. Despite the fact that the system has been under stress since the 1940s, sufficient historical water levels and data for estimating stresses are not available until about the 1960s. The combined effects of groundwater pumping for demands by irrigation and water supply have greatly depressed the groundwater levels in the most inland parts of the PVGB. The pumpage has also increased the vertical head differences at various depths within the aquifer system. Heads are higher in the shallow part of the aquifer system than at depth, with differences ranging from about $25 \mathrm{ft}$ near the Central Water District region on the northern inland boundary of the model to about 10 to $15 \mathrm{ft}$ near Elkhorn Slough at Hudson landing on the southern edge of the model. While the hydrologic system was not at steady-state during the early 1960 s owing to the changing vertical head gradients and the continued development of the groundwater resources, this early period was used to align this model with previous models and to start the simulation prior to the larger agricultural and climatic changes that occurred in the following decades. As a result of these conditions, the model does not represent steady hydrologic conditions in 1963. Therefore, there is little choice but to begin the simulation with initial conditions derived from a combination of water-level data and model-derived initial water levels. The groundwater flow simulation starts in 1963, for which there are enough data to generally map the groundwater levels throughout the regional aquifer system. These data were also used for the initial conditions for the previous PVIGSM model (Teghavi and Smith, 1999c).

When the simulation is started, the simulated heads and flows change in response to the initially specified and ongoing stresses. Because the irrigation and pumping stresses on the system change rapidly, the inconsistencies between the initially specified conditions and the simulated initial processes and properties generally are not problematic because the next stress regime soon dominates the solution (Hill and Tiedeman, 2007). As a result, comparing observed and simulated values becomes meaningful after a relatively short simulated time. This study and previous studies (Belitz and Phillips, 1995; Brush and others, 2006, Faunt and others, 2009a) show that the time frame for the stabilization is typically less than several months of the simulation.

\section{Model Calibration and Sensitivity}

Calibration of the model for transient-state conditions was dependent on the components of the use and movement of water across the landscape and their interplay with the streamflow network and groundwater flow system A total of 202 parameters were created to facilitate model calibration (table 13). Calibration started with adjustments of parameters within the landscape such as fractions of transpiration, irrigation efficiencies, stress factors for crop coefficients, and fractions of runoff. Then other features related to movement of water on the land surface, such as the hydraulic conductivity of the streambeds in the upstream portions of the streamflow network, and the recharge areas of the groundwater flow system, were adjusted. Finally, adjustments included and transitioned to the hydraulic properties of the central and coastal regions of the groundwater flow system.

The calibration of the part of the model that simulates the groundwater flow system involved adjustment of streambed vertical hydraulic conductivity parameters that influence recharge from streamflow infiltration, runoff parameters that influence areal recharge, and parameters that control discharge by pumpage, evapotranspiration, and base flow. Additional adjustment of inflows and outflows owing to groundwater underflow was part of the calibration process. The underflow to the aquifer system of the Pajaro Valley from adjacent inland regions to the north and south, along with coastal inflows and outflows, were controlled by hydraulic conductivity, storage, vertical hydraulic conductivity between layers, fault hydraulic characteristics, and general-head boundary (GHB) conductance.

Components of the water budget fall into two categories: specified fixed values, and calibrated values that are calculated (model output). Many of the water-budget components are specified values of inflows and outflows. Specified inflows and outflows that are not adjusted during calibration include stream inflows, urban pumpage, streamflow diversions, surface-water deliveries, monthly precipitation and $\mathrm{ET}_{\mathrm{h}}$, and many water-balance area and crop properties. Water-budget components calculated by the model and subject to calibration include streamflow gains/losses, outflow through the stream network, actual evaporation and transpiration, groundwater pumpage from agricultural uses, runoff from irrigation and from precipitation, farm-net recharge, wellbore flow through MNW wells, and change in storage. The implementation of 
the multi-node well package maintained the net pumpage but redistributed groundwater flow vertically between layers and allowed for intra-wellbore flow. This wellbore flow occurs during periods of pumpage and in unused wells, and also in wells that are only used periodically for water supply or irrigation. Model parameters related to smaller inflows and outflows, such as GHBs at the landward sides of the model and the submarine outcrops, also were adjusted during model calibration. With the addition of the years 2007-09 after the main calibration through 2006, the inclusion of tile drains was required to reduce rising groundwater during the recovery that began with the CDS deliveries to the coastal subregions.

\section{Measurements and Observations used in Model Calibration}

To assess model performance, simulated changes in water levels, vertical water-level differences, streamflows and diversions, streamflow gains and losses, and pumpage through time were compared to those changes measured in long-term monitoring wells and at streamflow gages, and in metered or reported pumpage. A total of 17,073 of these measurements (herein referred to as observations) were used to calibrate the model from 1963 to 2009. The locations and types of observation sites are shown in figure 28. In addition, qualitative comparisons were made of the CDS supplies and deliveries for the period 2002-09. Maps of groundwater levels were used for qualitative comparisons as well, but were considered less reliable than well data due to the spatial averaging involved in generating such maps. The distribution of error between simulated and observed values constrains the values of model parameters, allowing for improvement of model fit during calibration. Differences in simulated values as various model parameters are changed - their values either increased or decreased - provide the basis for analysis of the sensitivity of the model to the parameter adjustments.

Because so many variables can be adjusted in a model such as this, and so much about complex hydrologic systems is not known, there may be significant uncertainties in the application of the PVHM. These uncertainties and associated model limitations are discussed later in this report in the section "Model Uncertainty and Limitations."

\section{Groundwater Observations}

The largest suite of calibration targets was the groundwater levels and changes in groundwater levels over time. Observations as groundwater levels are the intial water level at each well and changes in water levels are drawdown since the intial water level and represent the rate of decline or recovery of groundwater storage. PVWMA maintains a database of water levels in key wells in the Pajaro Valley that are regularly measured as part of their monitoring network; these data were used for the calibration of the previous PVIGSM model and for the calibration of the PVHM model. A total of 11,506 water-level measurements from 73 single-well and multi-well monitoring sites (94 wells total; locations shown in fig. 28) were used for model calibration.

Hydrographs for these wells were constructed and examined; there are ten additional sites were included to supplement the sites used to calibrate the previous PVIGSM model. All comparisons of simulated to observed water levels are interpolated in time within a monthly stress period to the actual date of measurement. The single-well observation sites represent supply wells that are screened over multiple aquifers. Water-level comparisons at these sites required the estimation of composite heads that are interpolated across the portions of model layers represented by the screened intervals. Water levels from the multiple-well monitoring sites are depth- and aquifer-specific, and represent portions of the thicker model layers.

In order to represent the overall trends in heads throughout the region and to minimize the potential effects of initial conditions, the change in head relative to the first observation for the time span of measurements from each observation well were used as observation data for the PVHM. In addition to changes in water levels, 2,366 water-level differences were calculated between 20 monitoring wells completed in vertically adjacent aquifers at the 10 multi-well monitoring sites that span the coastal region from La Selva Beach (Soquel Creek Water District subregion 21) south to Hudson Landing near the Elkhorn Slough (Springfield Terrace subregion 9; figs. 1A, 2B, 28). These observations were included in the parameter estimation to help with the calibration of vertical hydraulic conductivity and distribution of pumpage during parameter estimation. 


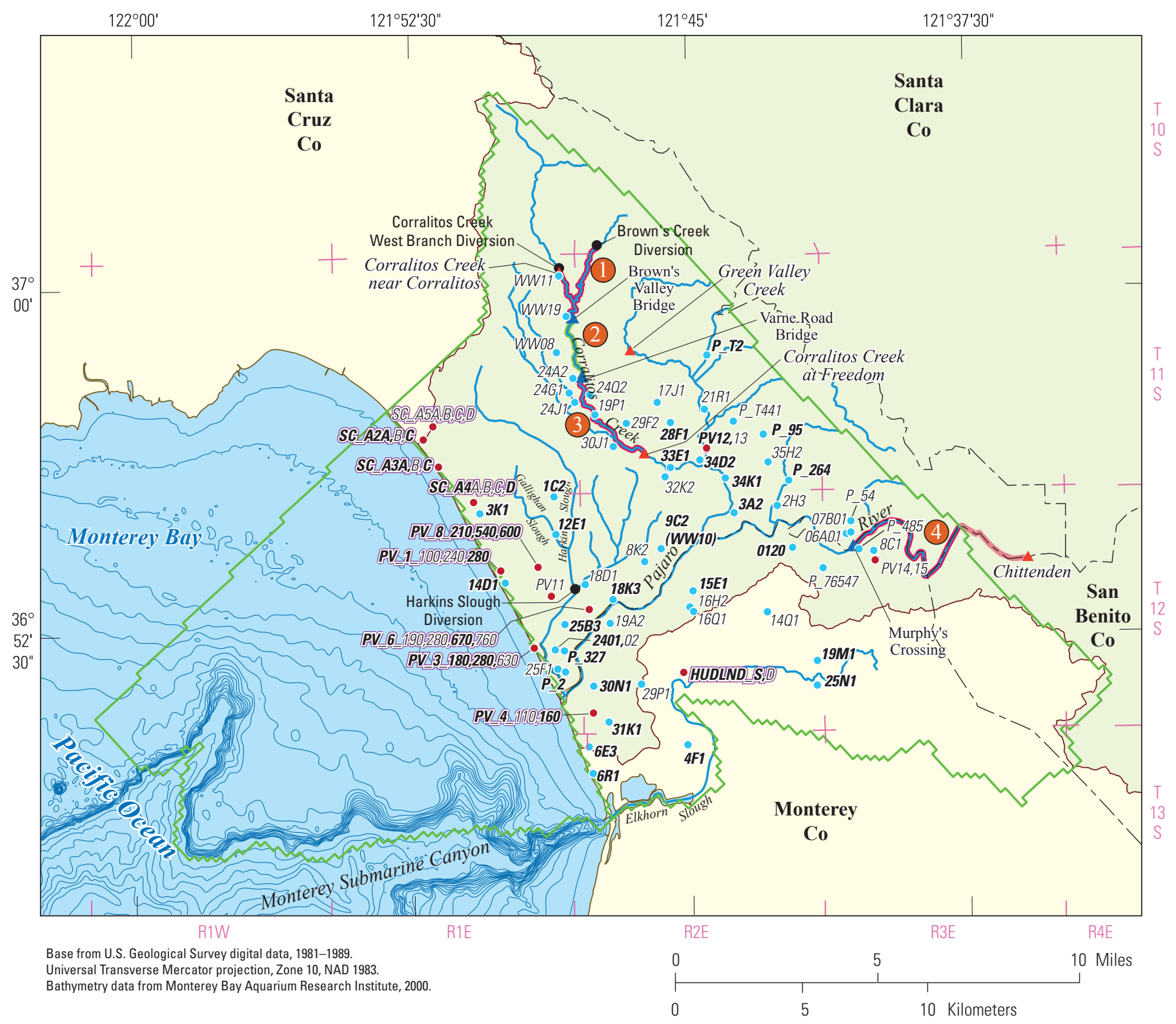

EXPLANATION

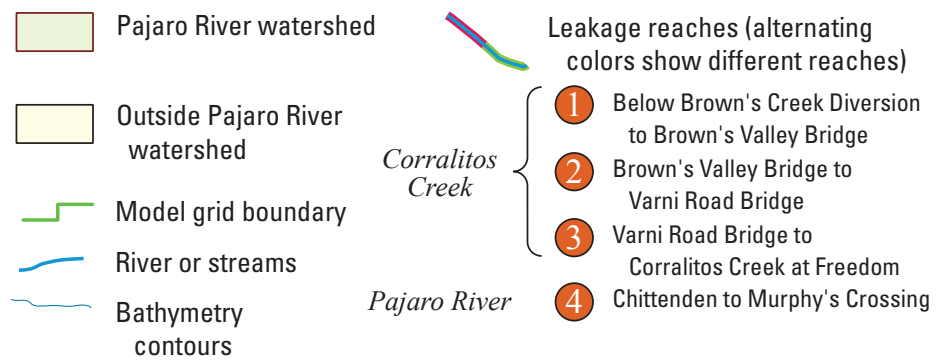

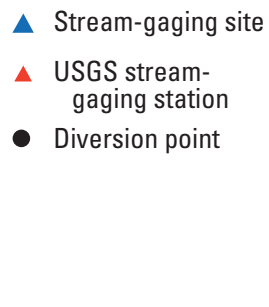

- Stream-gaging site

Calibration well—Hydrographs for well with numbers in bold are shown on figure 30

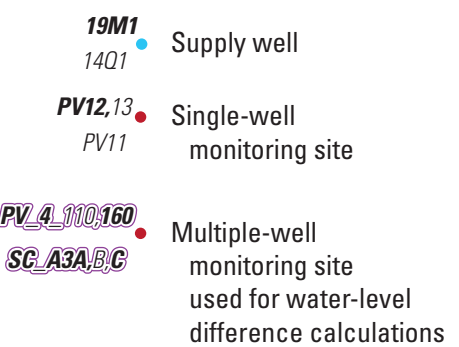

Figure 28. Calibration data sites, including wells for groundwater levels and water-level differences, streamflow gages, streamflow leakage reaches, and streamflow diversions for the Pajaro Valley Hydrologic Model, Pajaro Valley, California. 
The overall model fit for 11,506 water-level comparisons is generally good when the simulated head values are compared with the measured water levels. About 81 percent of the residuals were between -10 and $+10 \mathrm{ft}$, and 90 percent were between -20 and $+20 \mathrm{ft}$ (fig. 29A). Simulated water levels closely matched measured water levels, as indicated by an average residual of $-1.6 \mathrm{ft}$ and a sum of squared weighted residual (SOSWR) of $0.06 \mathrm{ft}$; the residuals ranged from -81 to $133 \mathrm{ft}$ and the standard deviation was $6.5 \mathrm{ft}$. These residuals are comparable to the fit of the previous PVIGSM model; however, the previous PVIGSM model was biased towards an overestimation of head (negative residuals), whereas the PVHM residuals are less biased and tend to underestimate water levels (positive residuals), which is considered a conservative bias in a coastal setting. In addition, more of the PVHM residuals are within $10 \mathrm{ft}$ of the measured values.
The total change in measured water levels in wells ranged from -55 to $73 \mathrm{ft}$ and the total simulated change in water levels at these well locations range from -46 to $55 \mathrm{ft}$. The crossplots of simulated versus measured water levels (herein referred to as correlation diagrams) for the major coastal and inland regions (figs. 2C, 29B) indicate that there are some outlier observations for which the model underestimated measured water levels in the inland regions and in the northern and central coastal regions. The central region shows some underestimation related to the amplitude of the seasonal waterlevel variations, but overall are still within a few meters of measured values for most observations. Simulated water levels show a better correlation with measured water levels in the southern coastal regions where a more accurate analysis of the effects of the ASR system and CDS system will be a critical part of the analysis of the BMP components.

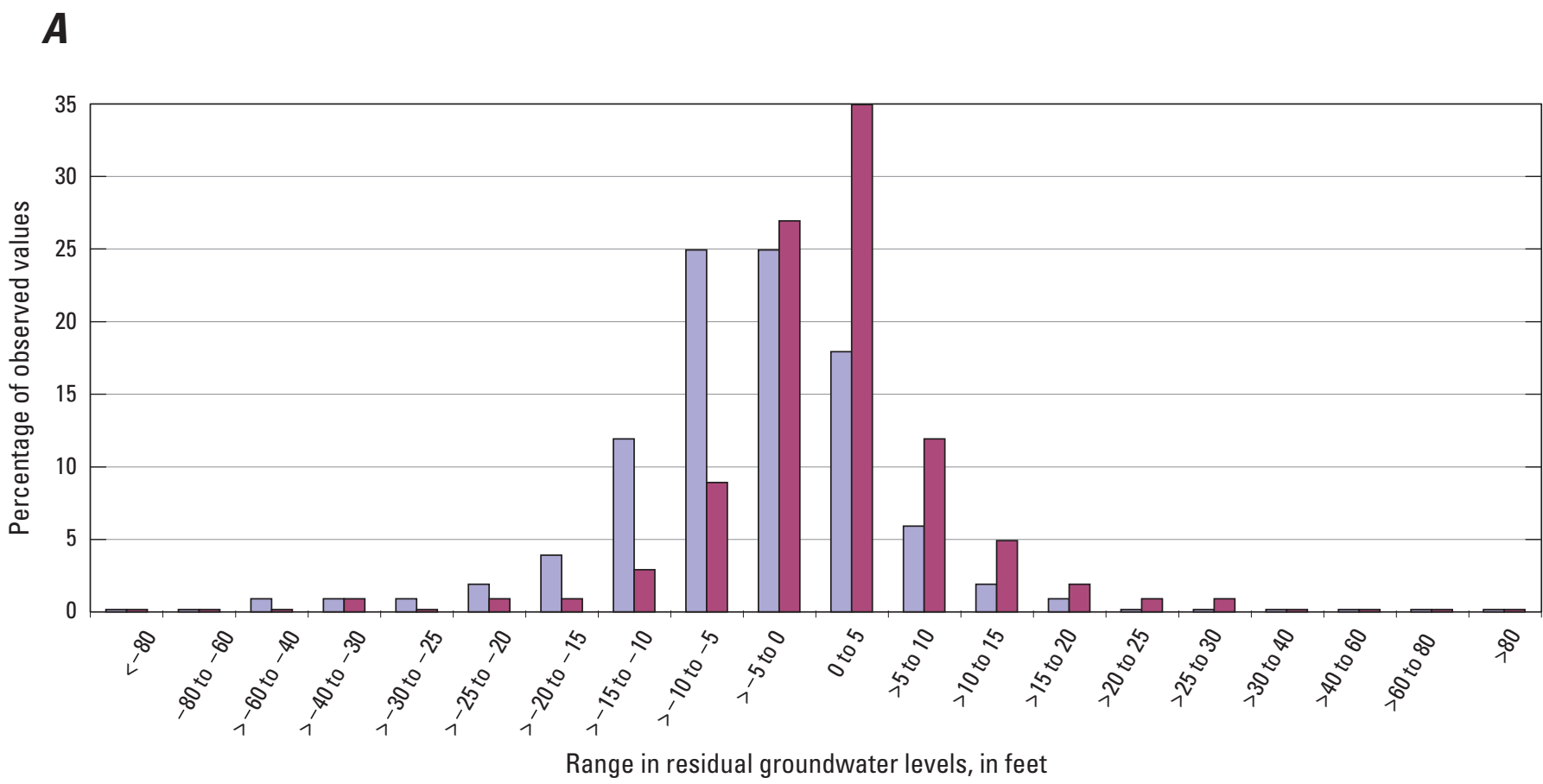

\section{EXPLANATION}

$\begin{array}{ccc}\begin{array}{c}\text { Range in residuals, } \\ \text { in feet }\end{array} & \text { Percentage of comparisons } \\ -10 \text { to }+10 & \text { PVHM } & \square \text { PVIGSM } \\ -15 \text { to }+15 & 78 & 74 \\ -20 \text { to }+20 & 88 & 88 \\ \text { Total Residuals } & 93 & 93\end{array}$

Figure 29. A, Histogram of distribution of water-level residuals (observed minus simulated) for the Pajaro Valley hydrologic model (PVHM) and the Pajaro Valley integrated groundwater-surface water models (PVIGSM); and $B$, correlation graphs of measured versus simulated water levels, by subregions, Pajaro Valley, California. [ $>$, greater than; $<$, less than] 
B

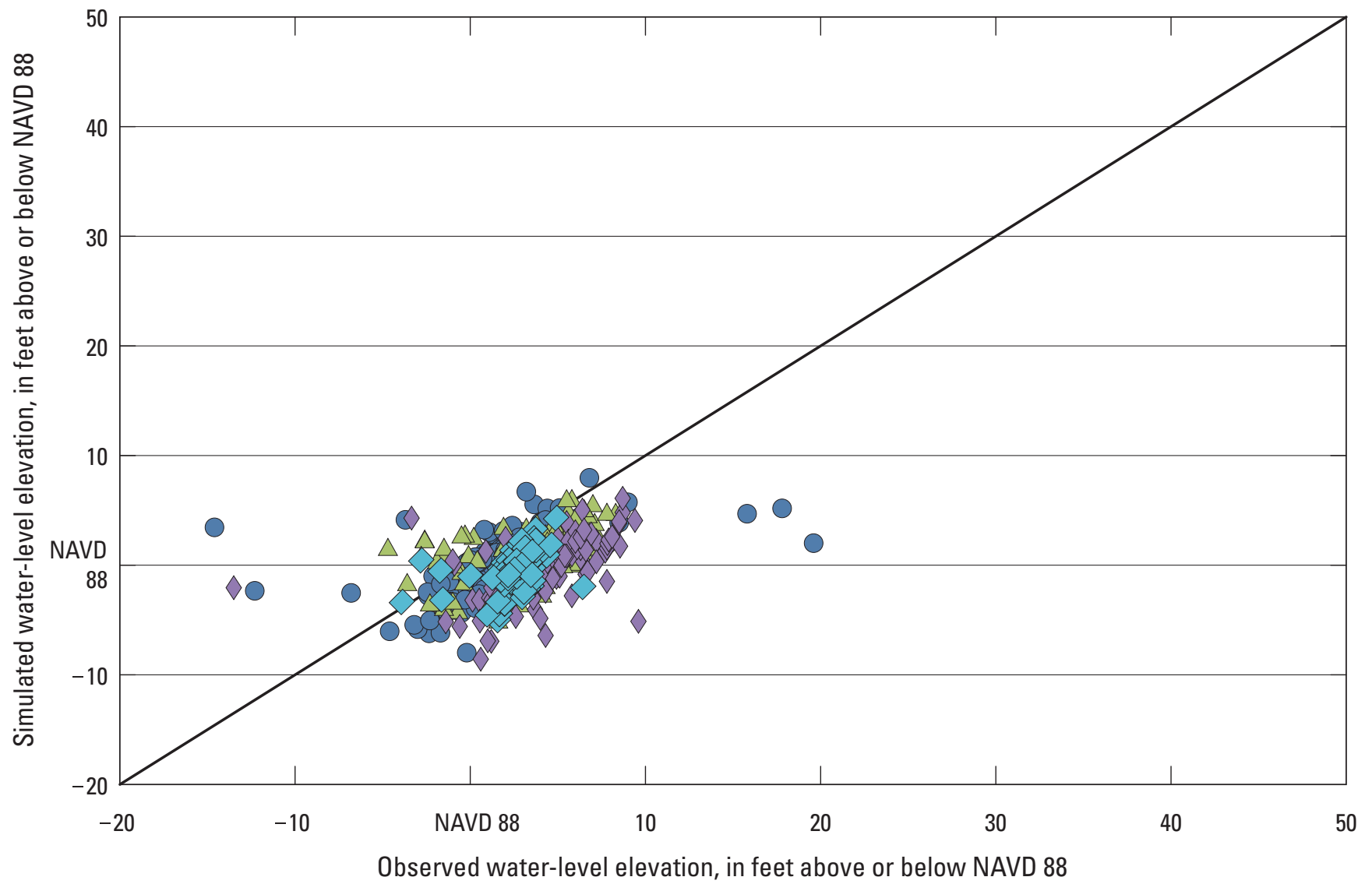

$$
\text { COASTAL - North }
$$

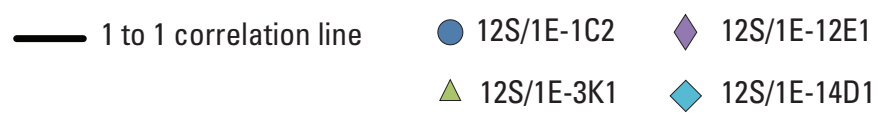

Figure 29. - Continued 
$\boldsymbol{B}$ (Continued)

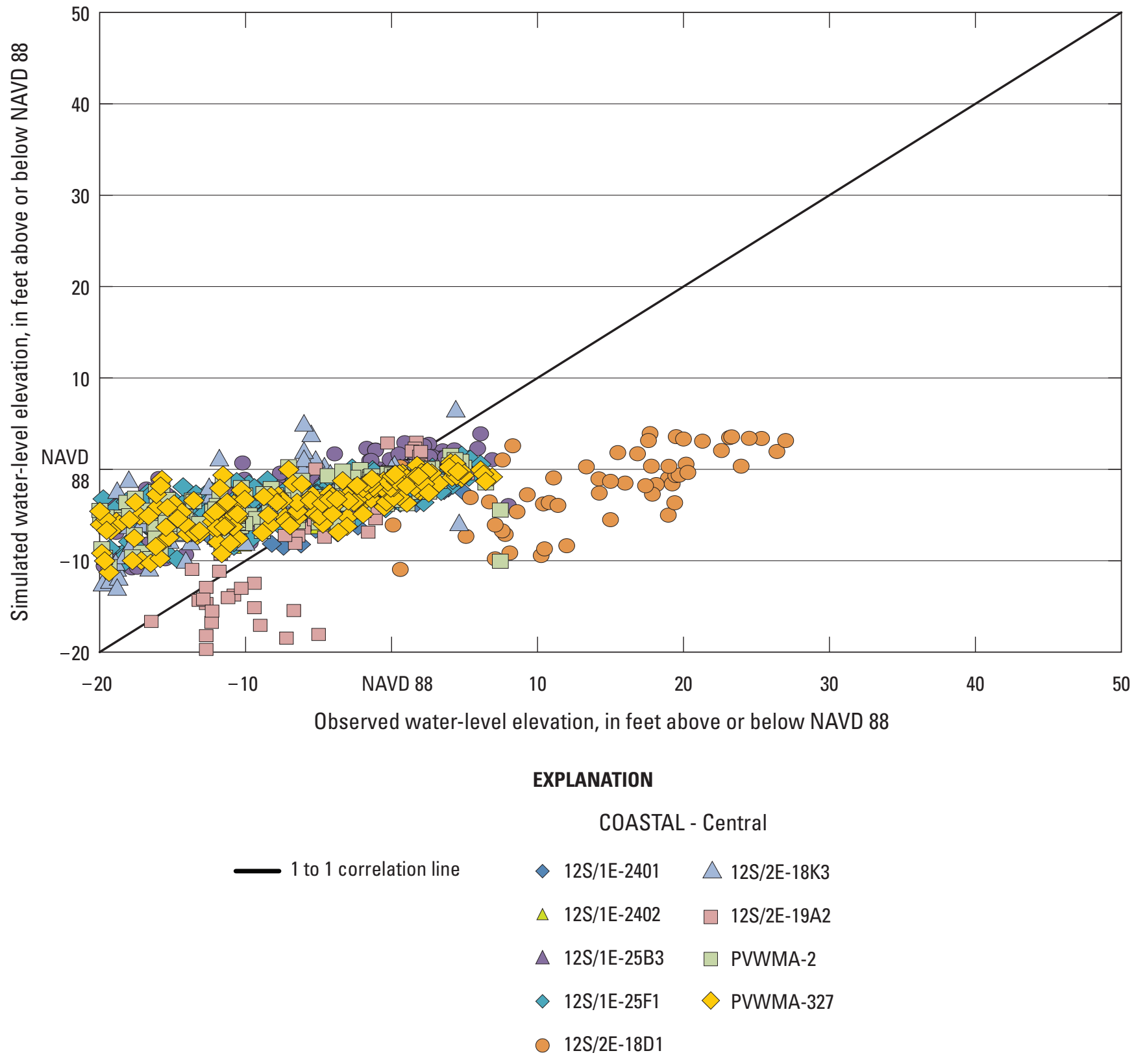

Figure 29. - Continued 
B (Continued)

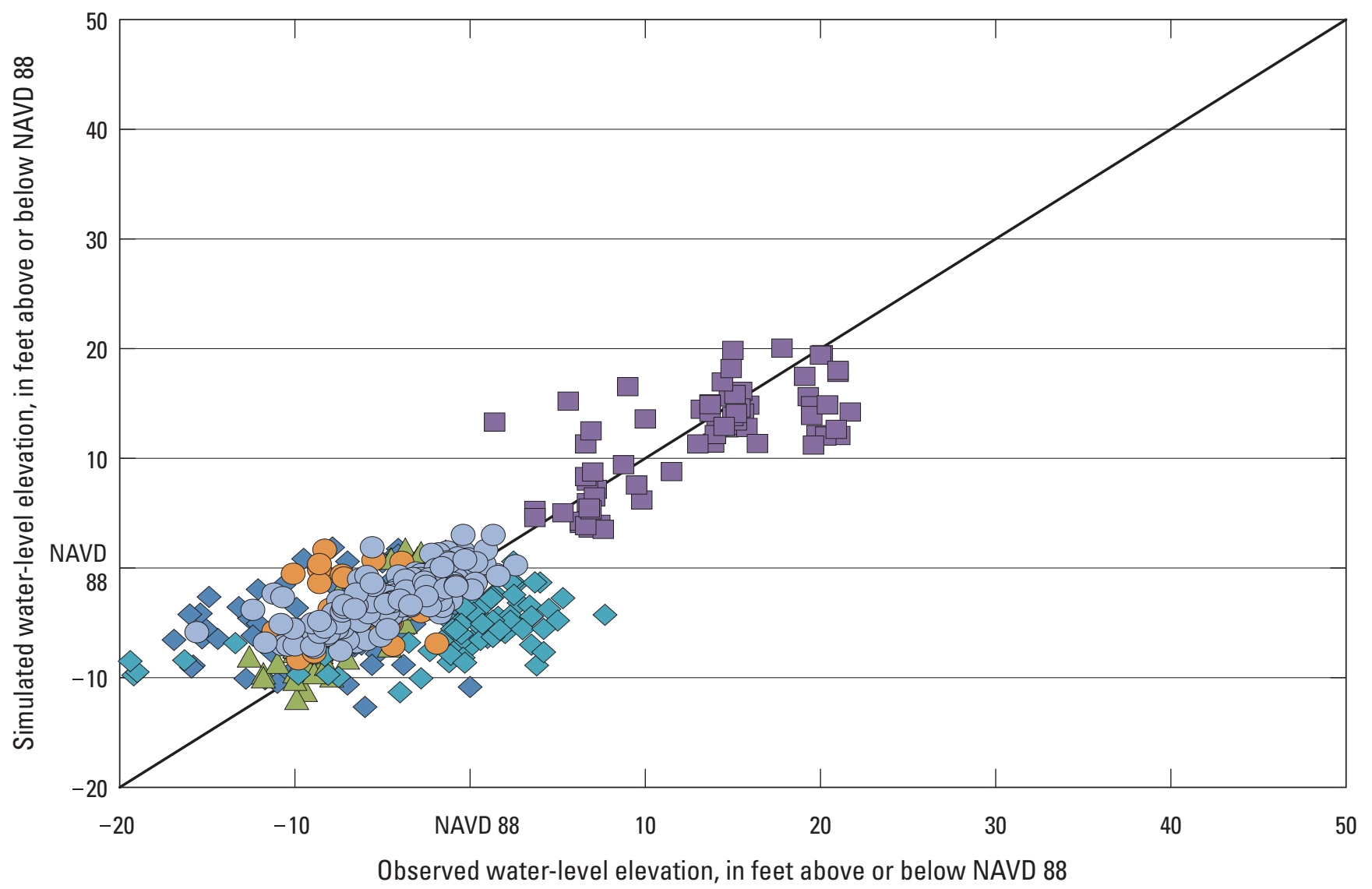

EXPLANATION

\section{COASTAL - South}

- 1 to 1 correlation line
$>12 \mathrm{~S} / 2 \mathrm{E}-30 \mathrm{~N} 1$
13S/2E-4F1
$\triangle 12 \mathrm{~S} / 2 \mathrm{E}-31 \mathrm{~K} 1$
$13 \mathrm{~S} / 2 \mathrm{E}-6 \mathrm{E} 3$
12S/3E-19M1
13S/2E-6R1

Figure 29. - Continued 
B (Continued)

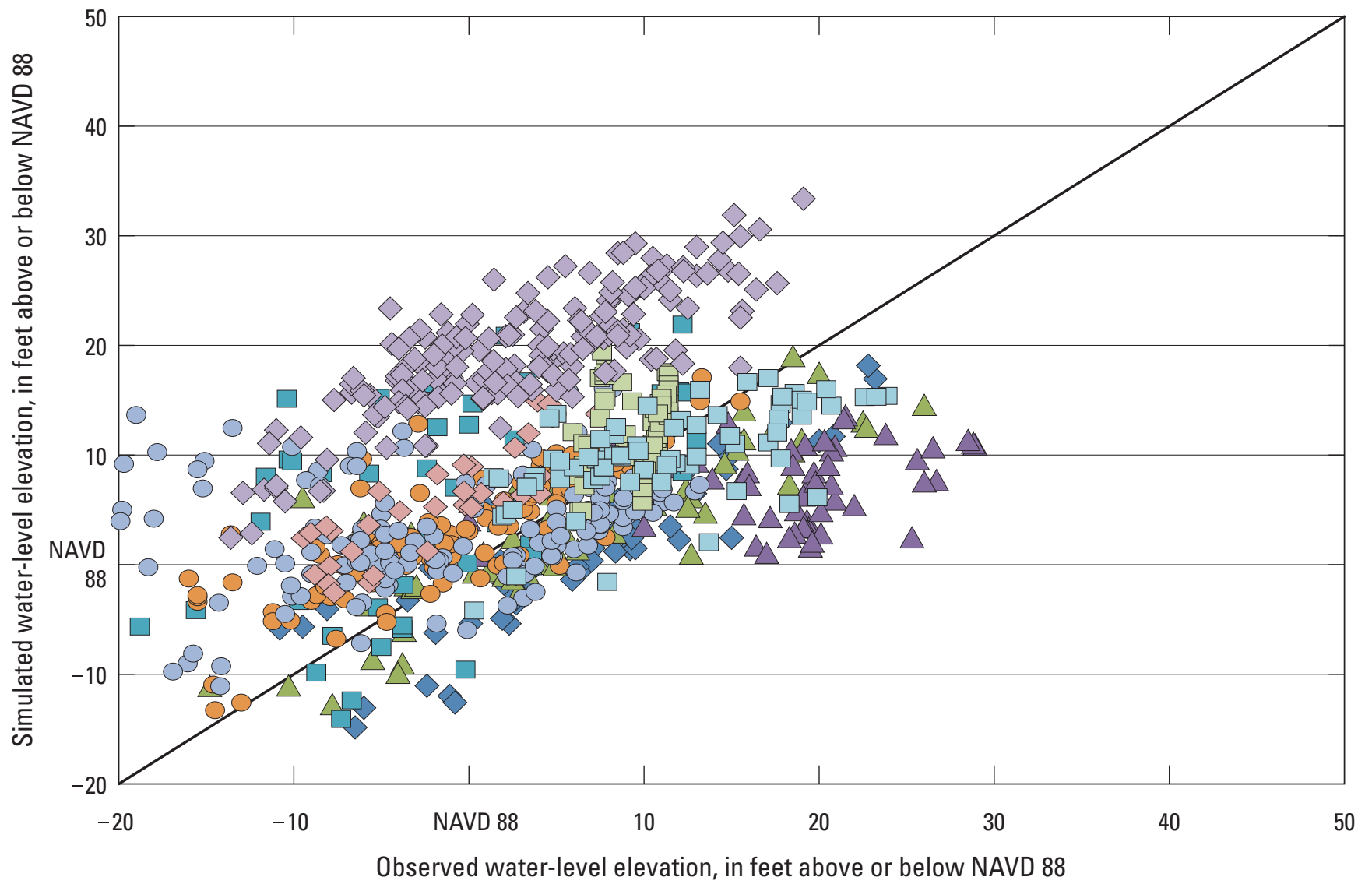

EXPLANATION

INLAND-Santa Cruz Basin

- 1 to 1 correlation line
$>$ 11S/2E-21R1
PVWMA-T2
$\triangle 11 \mathrm{~S} / 2 \mathrm{E}-28 \mathrm{~F} 1$
PV-12
$\triangle 11 \mathrm{~S} / 2 \mathrm{E}-29 \mathrm{~F} 2$
$\square \quad$ PV-13
$\square \quad 11 \mathrm{~S} / 2 \mathrm{E}-35 \mathrm{H} 2$
$\diamond$ PVWMA-264
- PVWMA-95
PVWMA-54

Figure 29. - Continued 
$\boldsymbol{B}$ (Continued)

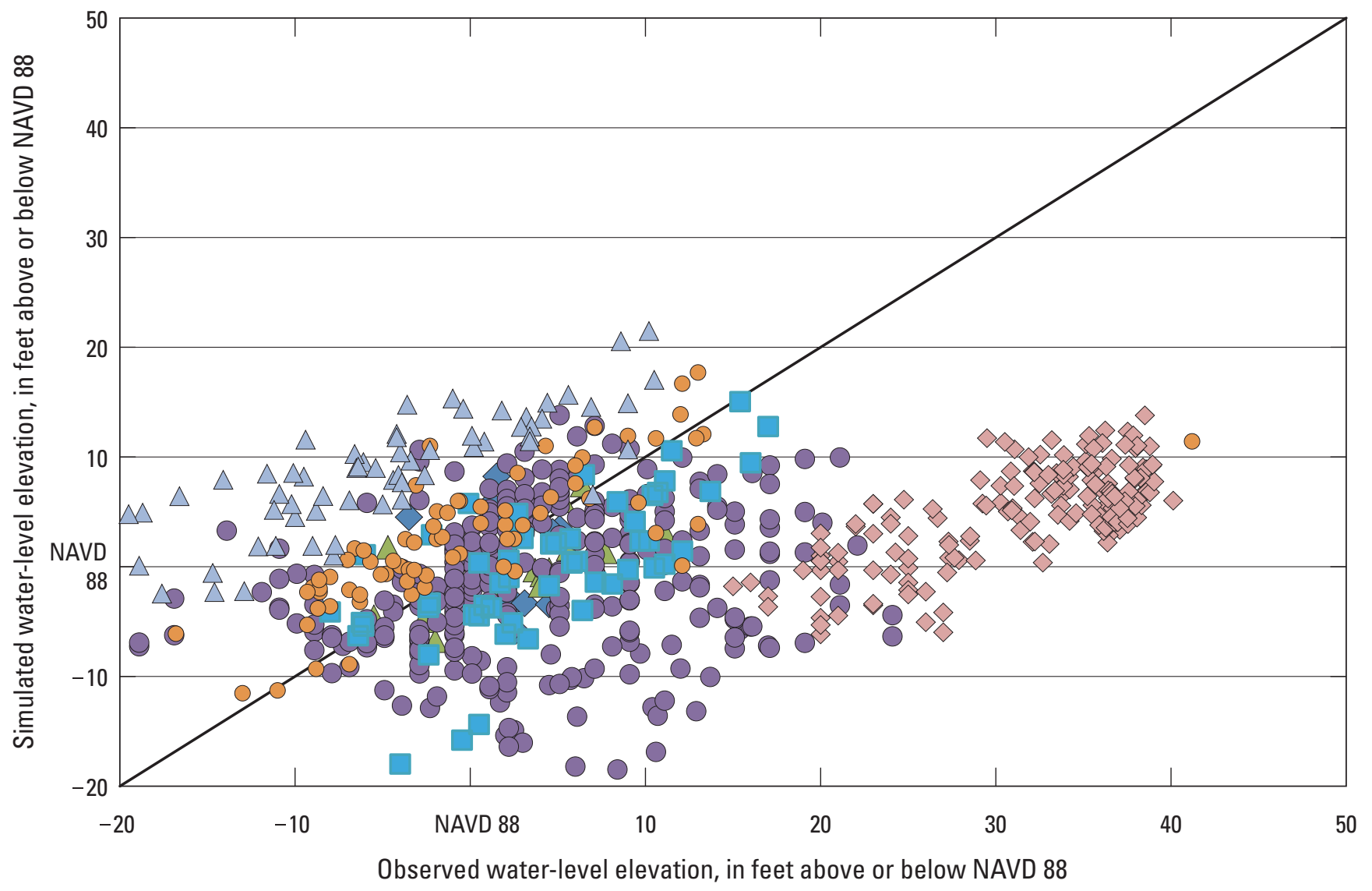

EXPLANATION

INLAND-Corralitos Creek

- 1 to 1 correlation line

$\begin{array}{llll}\diamond 11 \mathrm{~S} / 1 \mathrm{E}-24 \mathrm{~A} 2 & \diamond & 11 \mathrm{~S} / 2 \mathrm{E}-34 \mathrm{D} 2 \\ \triangle 11 \mathrm{~S} / 2 \mathrm{E}-19 \mathrm{P} 1 & \triangle & 11 \mathrm{~S} / 2 \mathrm{E}-34 \mathrm{~K} 1 \\ & 11 \mathrm{~S} / 2 \mathrm{E}-32 \mathrm{~K} 2 & \diamond & \text { WW19 } \\ \square & 11 \mathrm{~S} / 2 \mathrm{E}-33 \mathrm{E} 1 & & \end{array}$

Figure 29. - Continued 


\section{$\boldsymbol{B}$ (Continued)}

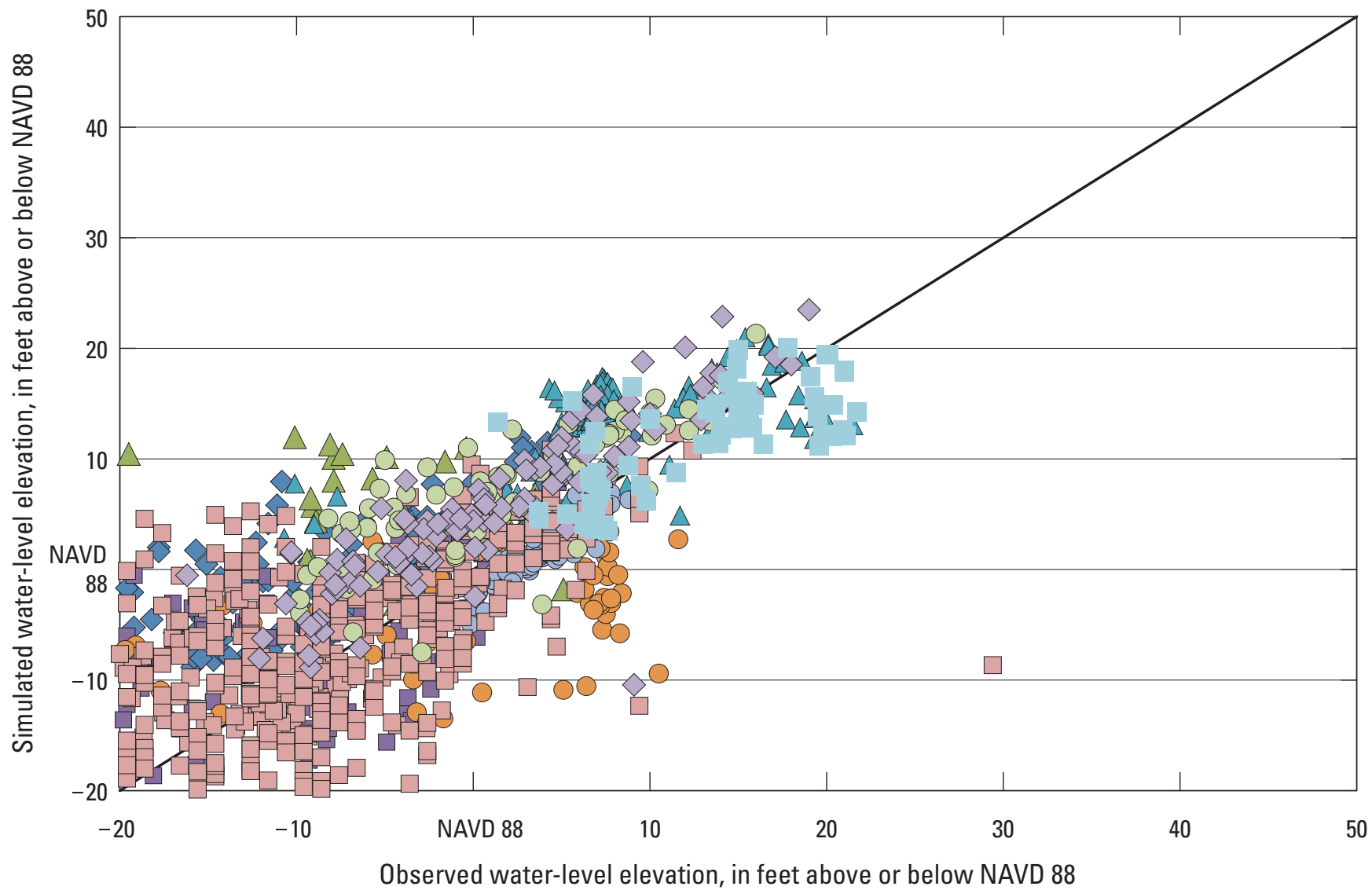

EXPLANATION

INLAND-Pajaro

— 1 to 1 correlation line
$12 \mathrm{~S} / 2 \mathrm{E}-15 \mathrm{E} 1$
WW10
$\triangle 12 \mathrm{~S} / 2 \mathrm{E}-16 \mathrm{H} 2$
- $12 \mathrm{~S} / 2 \mathrm{E}-3 \mathrm{~A} 2$
$\square \quad$ 12S/2E-1601
$12 \mathrm{~S} / 2 \mathrm{E}-0120$
$\triangle \quad 12 \mathrm{~S} / 2 \mathrm{E}-25 \mathrm{~N} 1$
$12 \mathrm{~S} / 2 \mathrm{E}-19 \mathrm{M} 1$
- $12 \mathrm{~S} / 2 \mathrm{E}-29 \mathrm{P} 1$
- HUDLND_S

Figure 29. - Continued 
B (Continued)

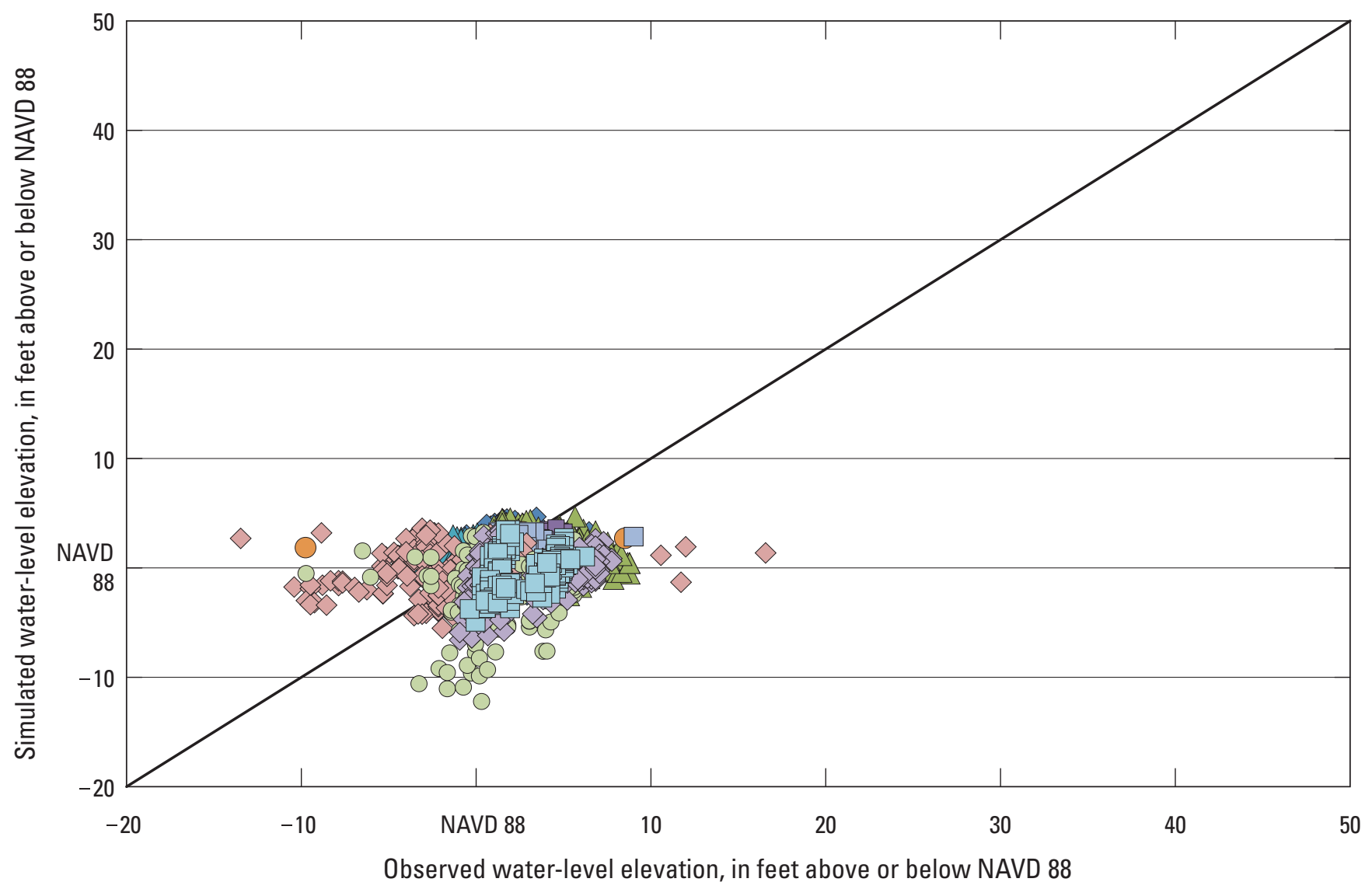

EXPLANATION

COASTAL - North Monitoring Wells

$\begin{array}{rlll}-1 \text { to } 1 \text { correlation line } & \diamond \text { SC_A2A } & \triangle \text { SC_A3A } & \diamond \text { SC_A4A } \\ & \triangle \text { SC_A2B } & \bigcirc \text { SC_A3B } & \bigcirc \text { SC_A4B } \\ & \square \text { SC_A2C } & \square \text { SC_A3C } & \diamond \text { SC_A4C } \\ & & & \text { SC_A4D }\end{array}$

Figure 29. - Continued 


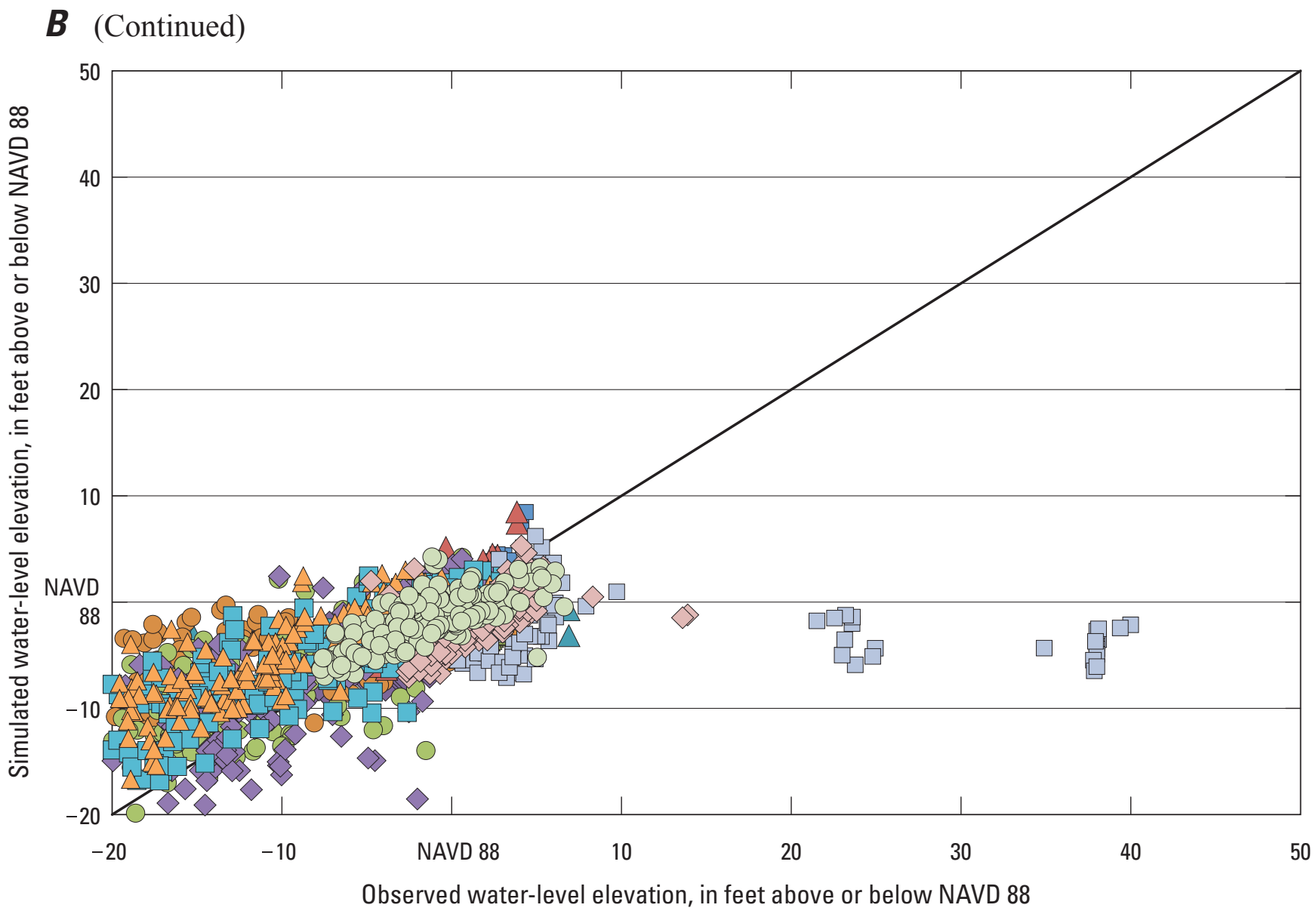

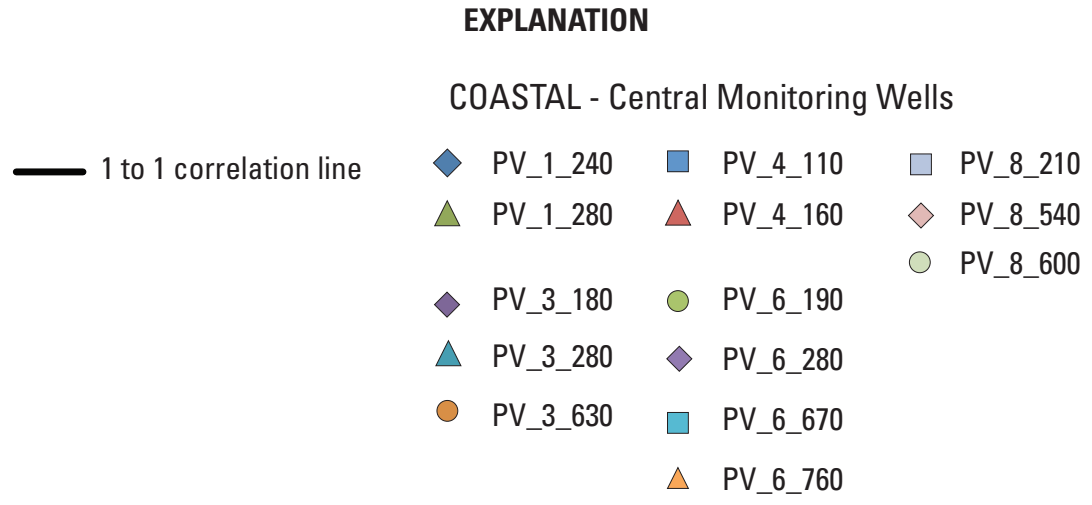

Figure 29. - Continued 
Hydrographs showing both simulated and measured heads for selected wells help to illustrate the match of water levels throughout the upper and lower parts of the system (fig. 30). The minimum period over which model simulations can accurately reproduce fluctuations in the groundwater flow system (the response time of the model) varies with the depth to groundwater, hydrologic setting, hydraulic properties, climate, and land use. The amplitude of monthly fluctuations in simulated heads are generally less than fluctuations in measured heads, are smallest at the water table, and increase with depth below the land surface owing to: the actual daily variations in rates of pumping and recharge associated with irrigation, versus the monthly average rates simulated; the transition between unconfined and confined conditions; and proximity to the coast.

The goal of the model calibration was to try to match individual groups of hydrographs, and to minimize the SOSWR for all simulated heads associated with measured values. The use of water-balance areas that represent multiple farms, estimated pumpage rates, spatially and temporally coarse (multi-year) land-use and crop distributions for the periods prior to the last two decades, and assumptions made in spatially distributing pumpage may limit the accuracy of the model for the periods prior to about 1999. The spatial distribution of the residuals and water-level matches is discussed in more detail in the "Groundwater-Levels Map" section. Much of the error, and the primary source of the positive/negative average error, may be associated with the lack of spatial and temporal detail in land use estimates in the inland WBSs that ultimately drive ET consumption through irrigation and pumping.

The data indicate that simulated heads for the period 1963-2009 are in general agreement with the measured water levels and changes in water levels. The model closely matches measured water levels during some periods, but overestimates or underestimates water levels at other times. The model reasonably represents changes in water levels in response to seasonal changes as well as major features in the climate record, including droughts during 1976-77 and 1987-91, periods of higher than normal precipitation in 1983-84, and sequential individual dry-wet years such as 1997 and 1998.

Vertical water-level differences from measured water levels range between $-12 \mathrm{ft}$ (upward gradient) and $16 \mathrm{ft}$ (downward gradient; fig. 31). Residuals between observed and simulated vertical water-level differences generally ranged from -11.5 to $9.1 \mathrm{ft}$ and were largest between the lower Aromas (layer 5) and the upper parts of the Purisima Formation (layer 6) at the north coastal regions of the model (PV8 on fig. 31). The water-level-differences fit is best for wells in the shallower layers, such as PV-1, PV-4, PV-8, SC-A4, and Hudson Landing (fig. 31). About 58 percent of the simulated head differences are within $2 \mathrm{ft}$ of the measured head differences. The differences between observed and simulated water-level differences are generally small, but for some periods are opposite in sign for many of the deeper well pairs between the lower Aromas and upper Purisima layers, which indicates that the model is simulating upward gradients and overestimates the water levels in the Purisima in the northern coastal regions. This issue is not only present in the PVHM but was problematic in the previous PVIGSM model, and may reflect uncertainty over screened intervals or distributions of pumpage into the upper part of the Purisima. Lower observed than simulated pressures in the Purisima may reflect a greater influence from pumpage in the Purisima just north of Pajaro Valley or less recharge or coastal inflow than is simulated in the PVHM. Overall, the water-level differences are similar in magnitude and sign, and for many sites improve (become smaller) in the later (more recent) years with the availability of more detailed information on land use that is driving the agricultural consumption and related pumpage.

A comparison of the simulated and measured water levels across the valley indicates that the model is fairly accurate in the central and southern coastal regions and within the region of the Pajaro River Valley, but does not replicate the elevated water levels in wells screened in the perched Alluvial aquifer in the Corralitos area. The alluvium would need to be further subdivided into additional layers to capture this feature. Similarly, the model does not replicate the water levels at PV-11, north of the Pajaro Valley, where some perching of water in the alluvium also occurs. The model overestimates the seasonal changes in water levels in some of the monitoring and supply wells that are screened in the lower Aromas north of the Pajaro River Valley. This may be due to uncertainties in simulated values for the aquifer characteristics of the lower Aromas, and a different zonation may still be required to yield larger storage properties in parts of the Lower Aromas.

Average residuals for the wells used for comparison do not show systematic regional bias except for the perched aquifers within the Alluvial aquifer layer of the Corralitos area (fig. 32). There are a few larger positive residuals (observed greater than simulated) closer to the mountain front that may be the result of an underestimation of recharge. Underestimation of recharge could be the result of poorly constrained estimates of ungaged streamflow and streamflow infiltration along the mountain front west of the San Andreas Fault, or from the need to separate the natural vegetation into a separate category for forested regions, where deep percolation of recharge may be larger. The model underestimates the climate-driven changes of the early decades prior to the drought of the 1980's in the inland regions and tends to slightly overestimate the climate-driven changes that occur after this drought. There may be a change in recharge that occurred after about 1989 that reflects the larger climate variations seen in the early period compared with the more damped response that is more evident in the later record of water levels from most wells. 
$\boldsymbol{A}$

Santa Cruz County Inland

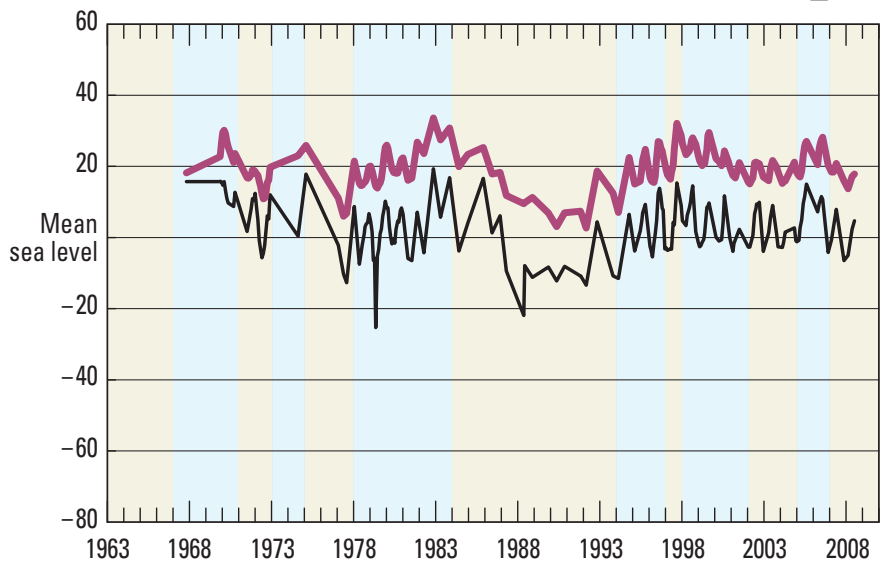

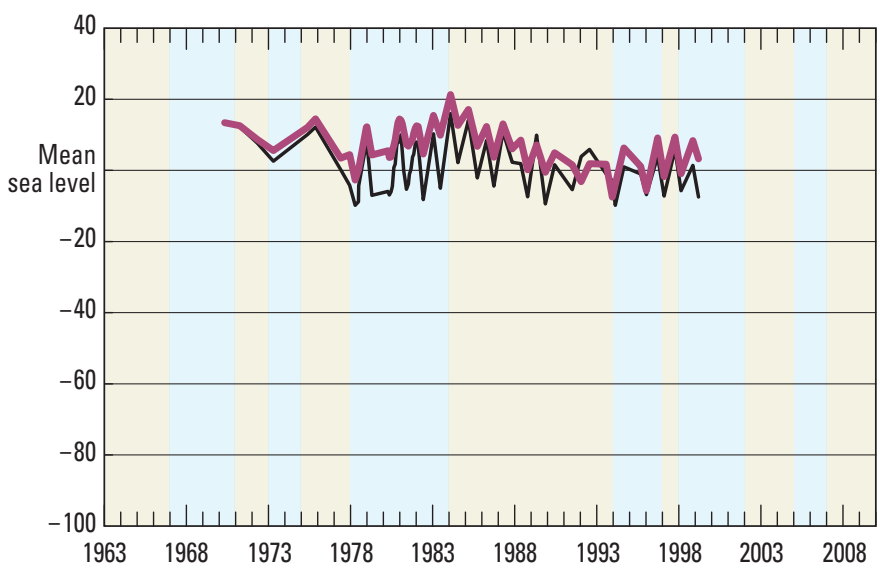

$34 D 2$
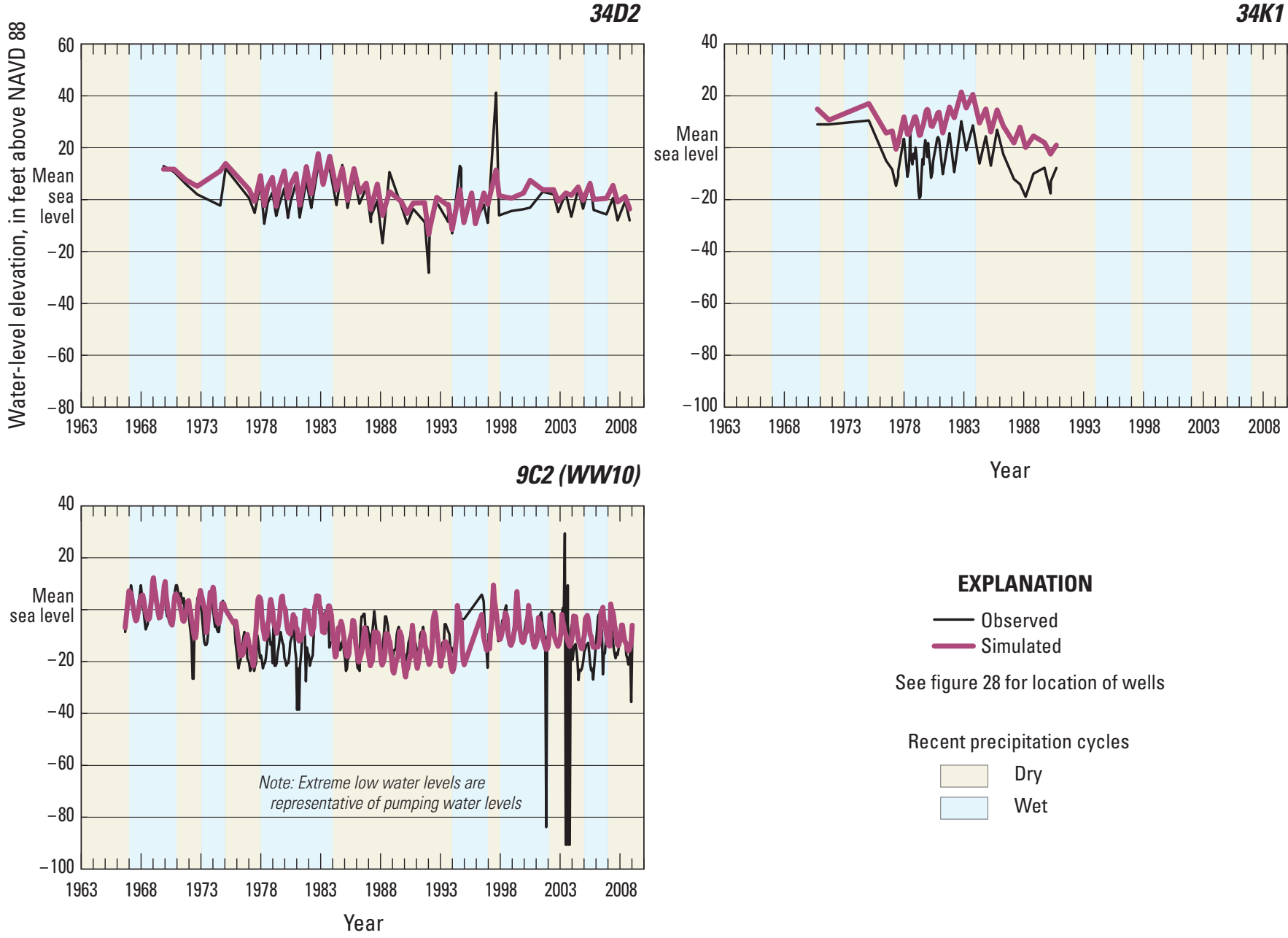

EXPLANATION

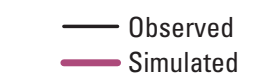

See figure 28 for location of wells

Recent precipitation cycles

$\begin{aligned} & \square \text { Dry } \\ & \square\end{aligned}$

Wet

Figure 30. Simulated and measured hydrographs for selected wells in $A$, Santa Cruz County Inland; $B$, Monterey County Inland; $C$, Santa Cruz County Coastal (Non-CDS); $D$, Santa Cruz County Coastal (CDS); E, Monterey County Coastal (Non-CDS); F, Monterey County Coastal (CDS); and G, Santa Cruz County Monitoring Wells, Pajaro Valley, California. 
A (Continued)

Santa Cruz County Inland
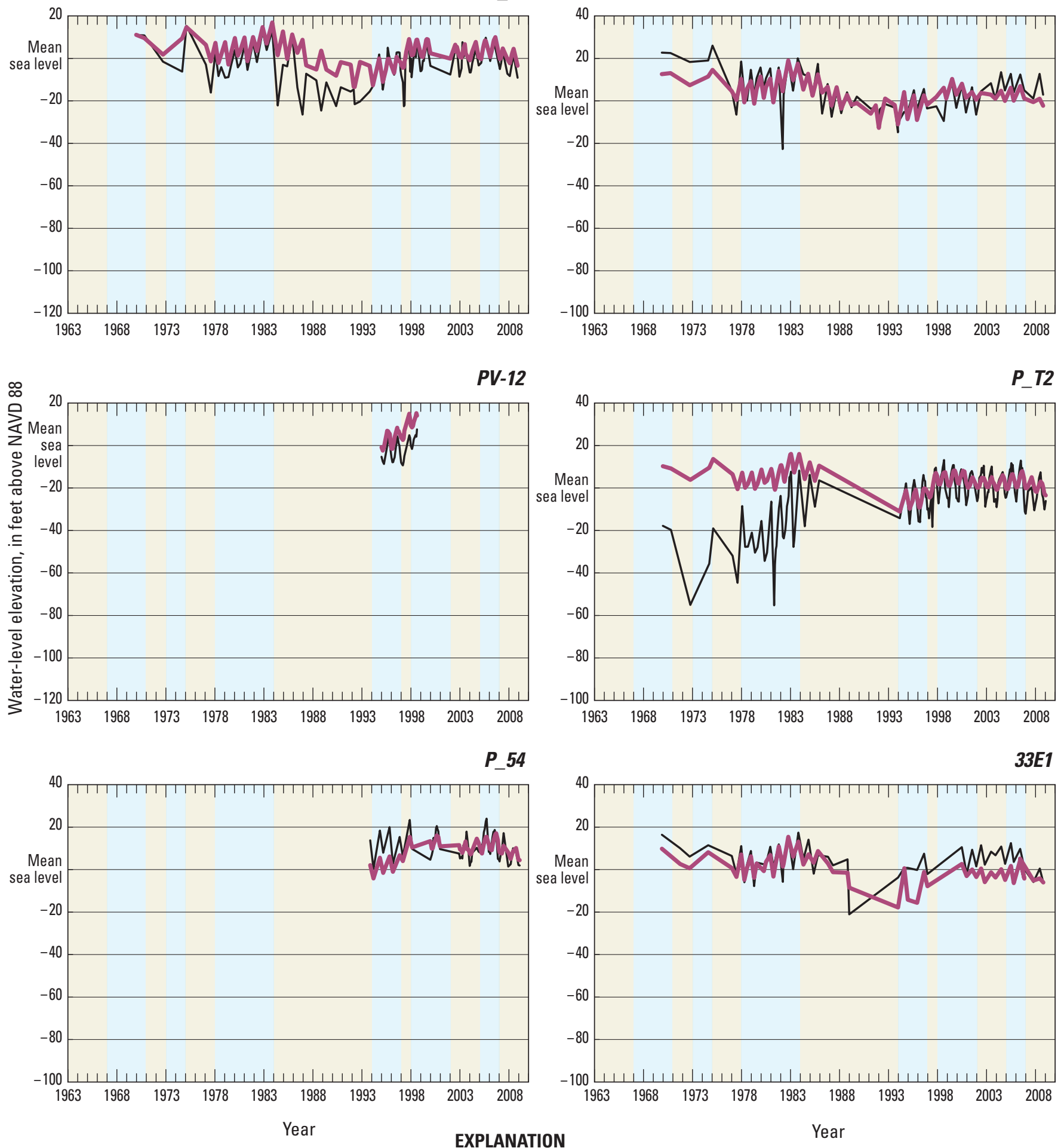

EXPLANATION

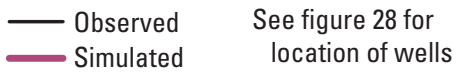

Recent precipitation cycles location of wells

Dry

Wet

Figure 30. - Continued 


\section{B Monterey County Inland}

HUDLND_S
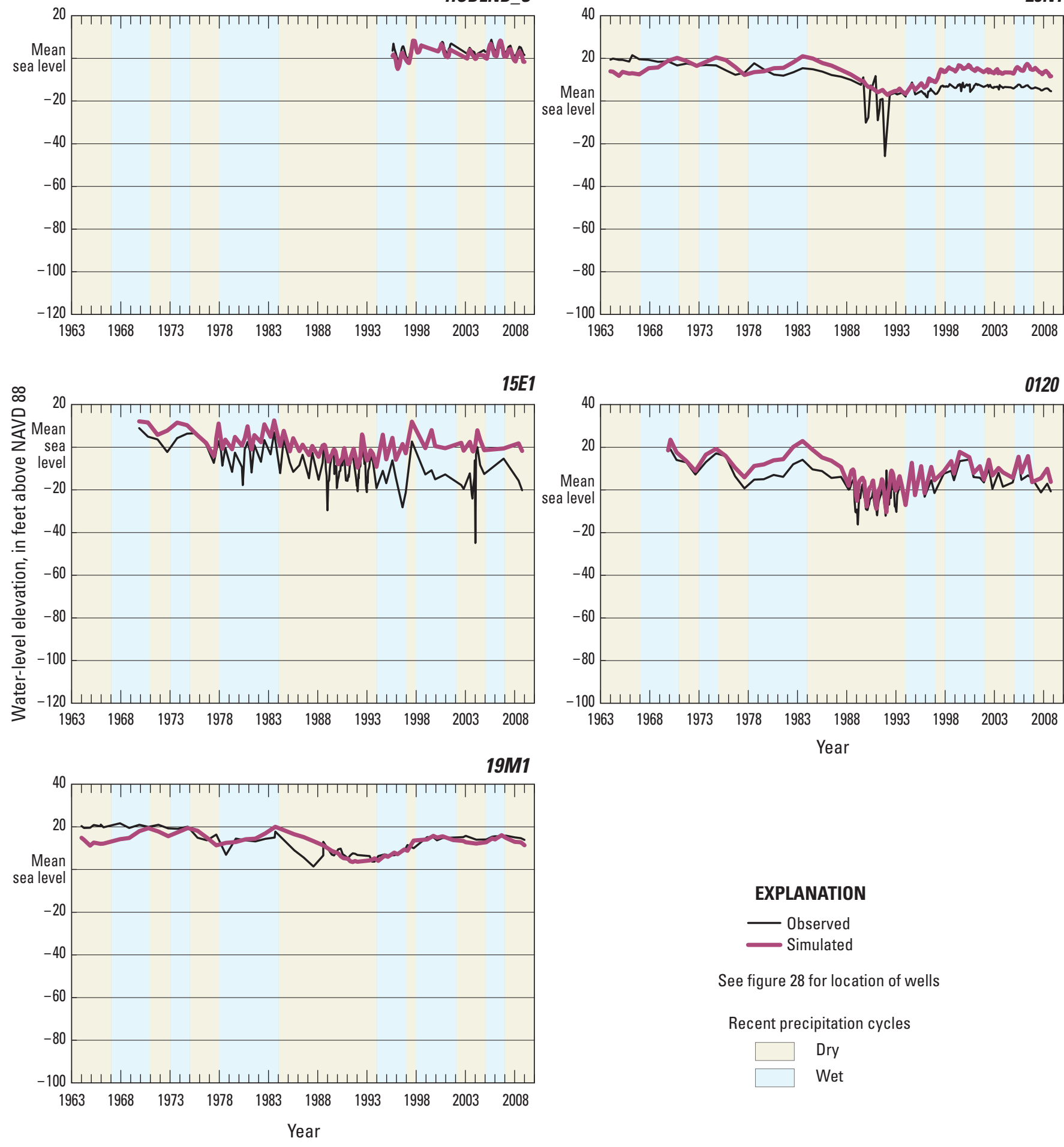

EXPLANATION

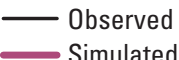

See figure 28 for location of wells

Recent precipitation cycles

$\square$ Dry

Wet

Figure 30. - Continued 
C

Santa Cruz County Coastal (Non-CDS)
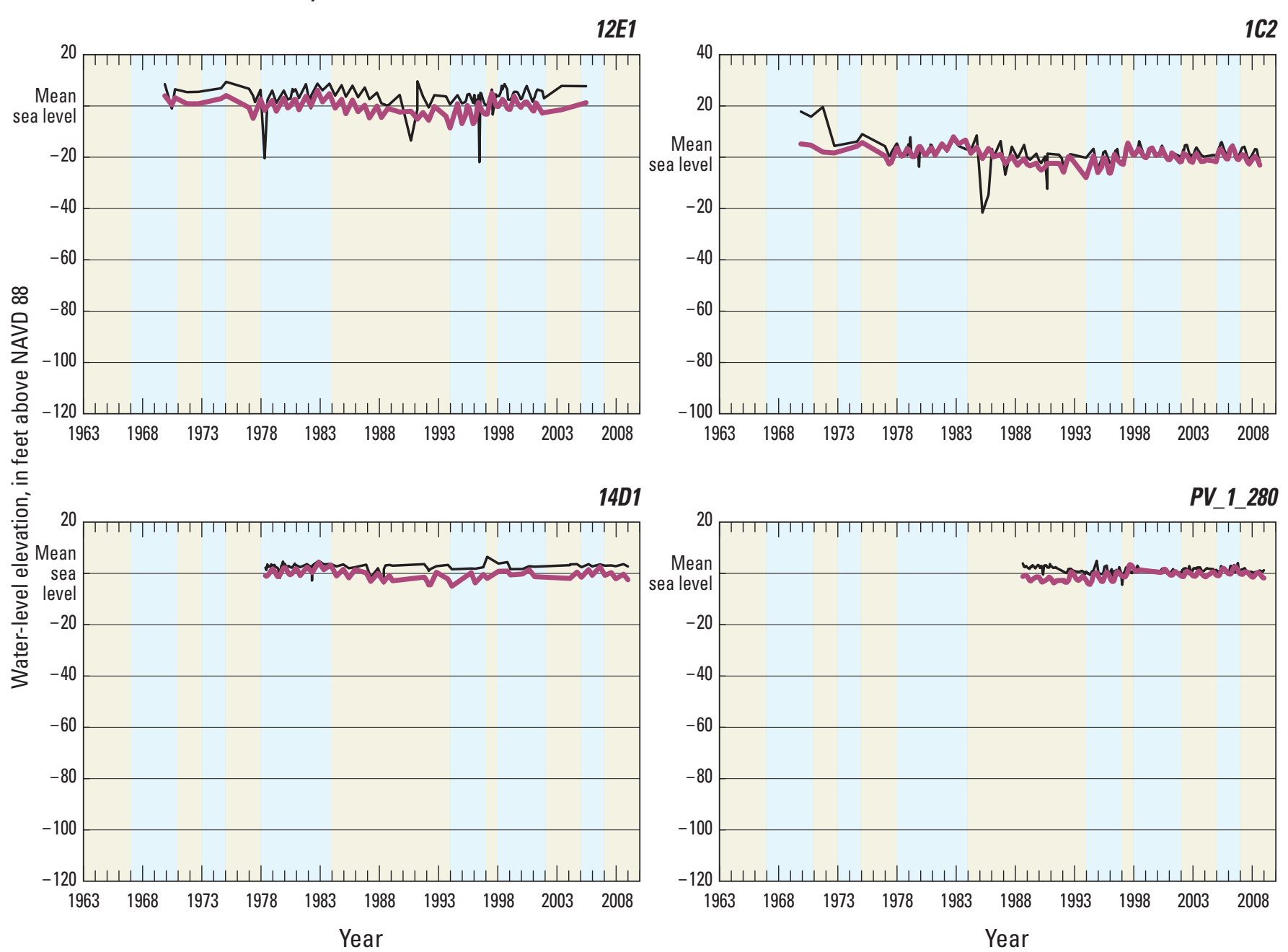

EXPLANATION

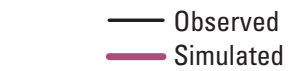

See figure 28 for location of wells

Recent precipitation cycles

$\square$ Dry

Figure 30. - Continued 
C (Continued)

Santa Cruz County Coastal (Non-CDS)

PV_8_210

PV_8_540
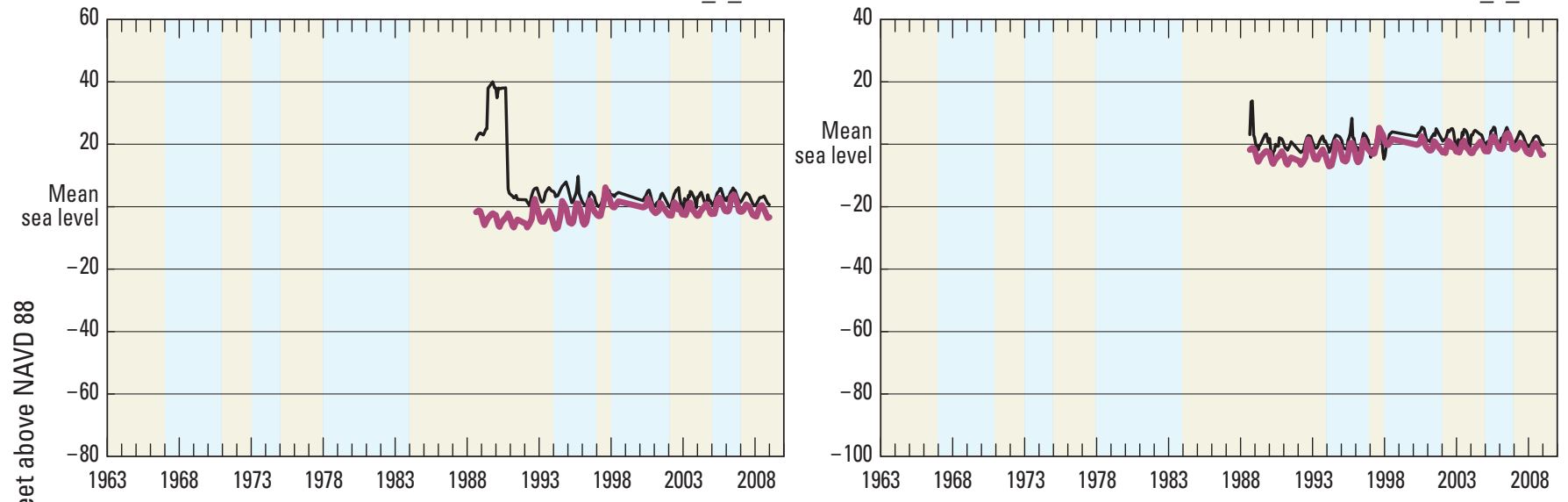

PV_8_600

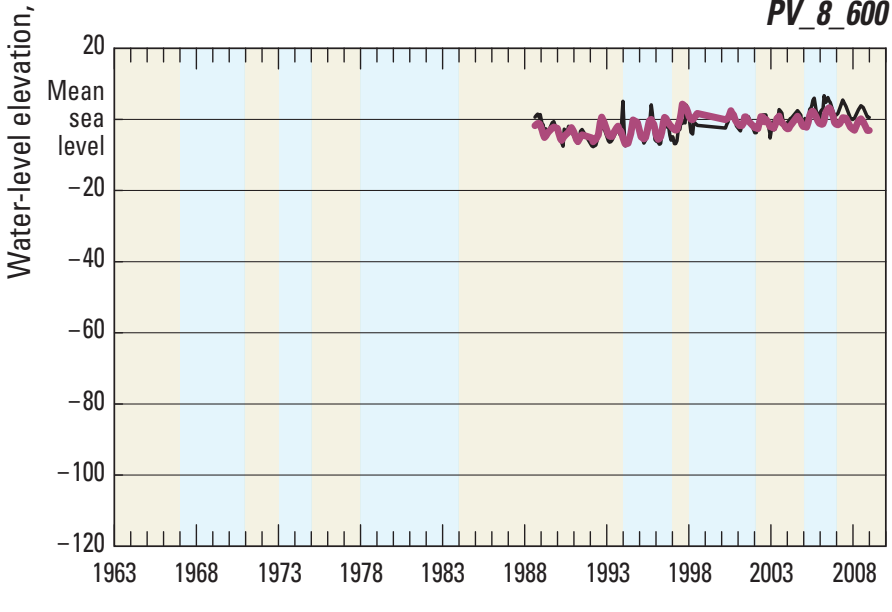

Year

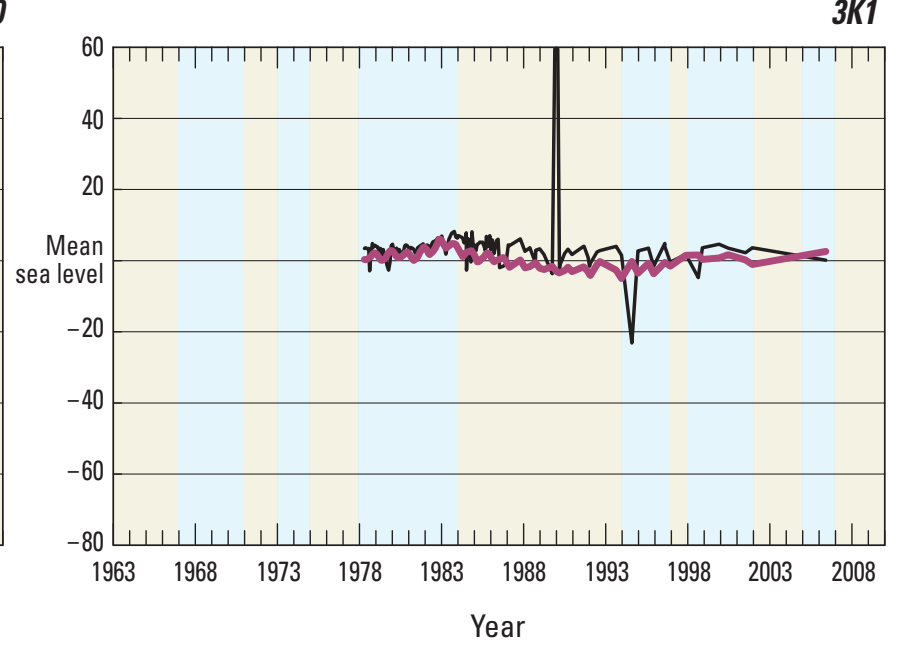

EXPLANATION

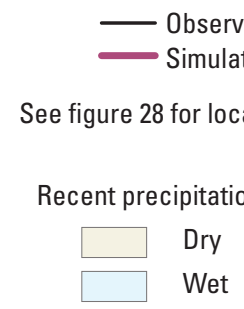

Figure 30. - Continued 


\section{D}

\section{Santa Cruz County Coastal (CDS)}
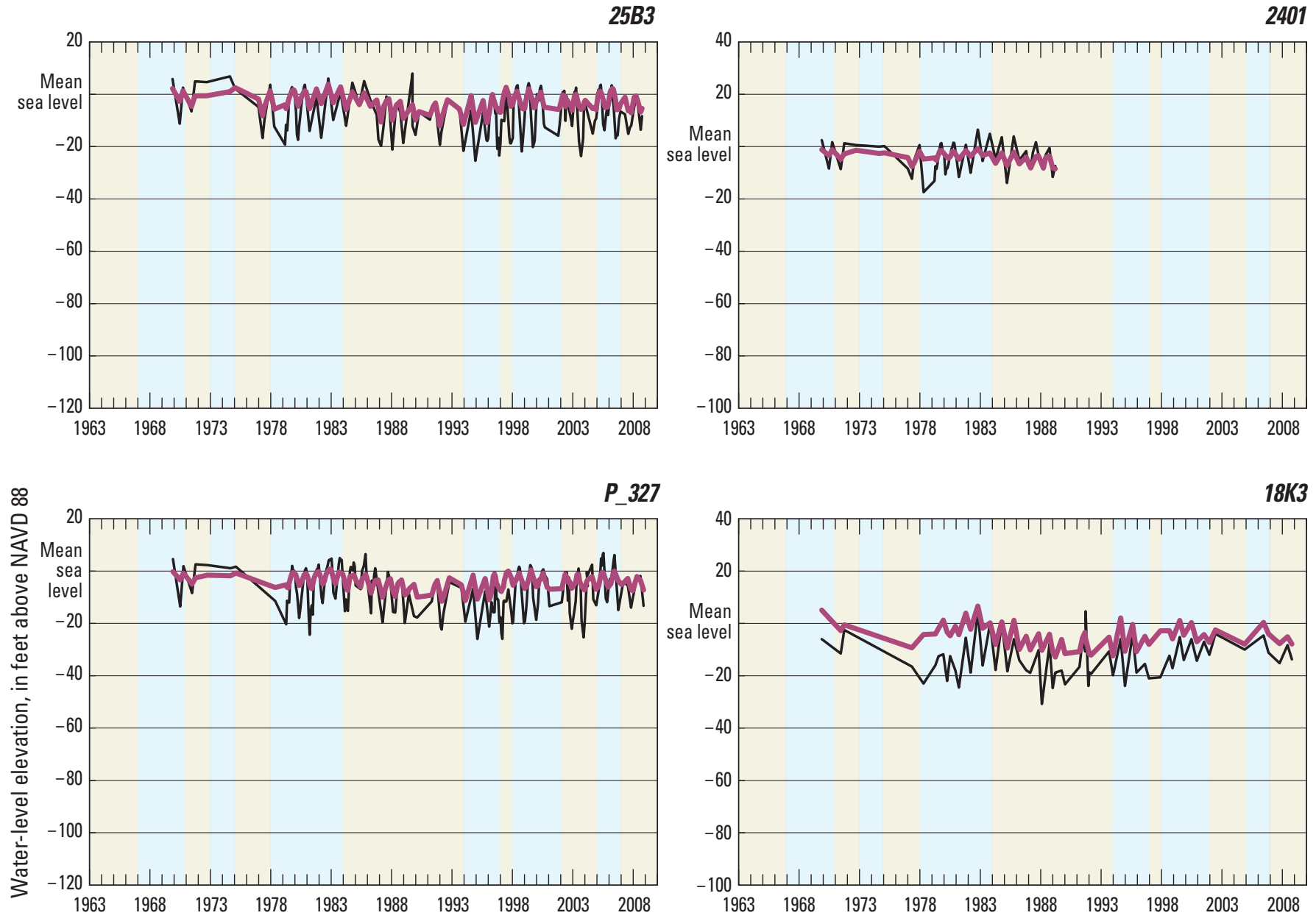

P 2
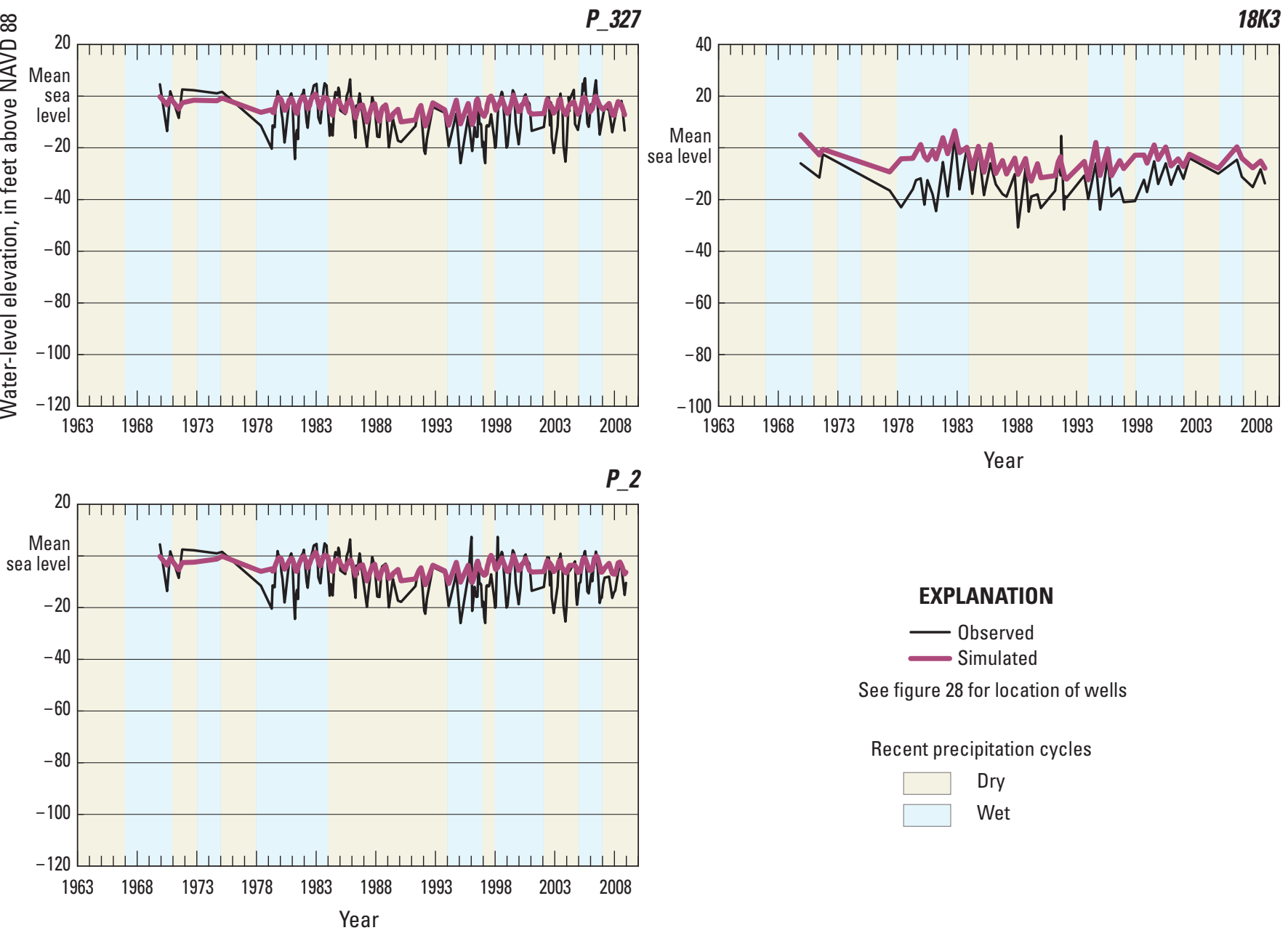

See figure 28 for location of wells

Recent precipitation cycles

Figure 30. - Continued 
D (Continued)

\section{Santa Cruz County Coastal (CDS)}

PV_3_180

PV_6_670
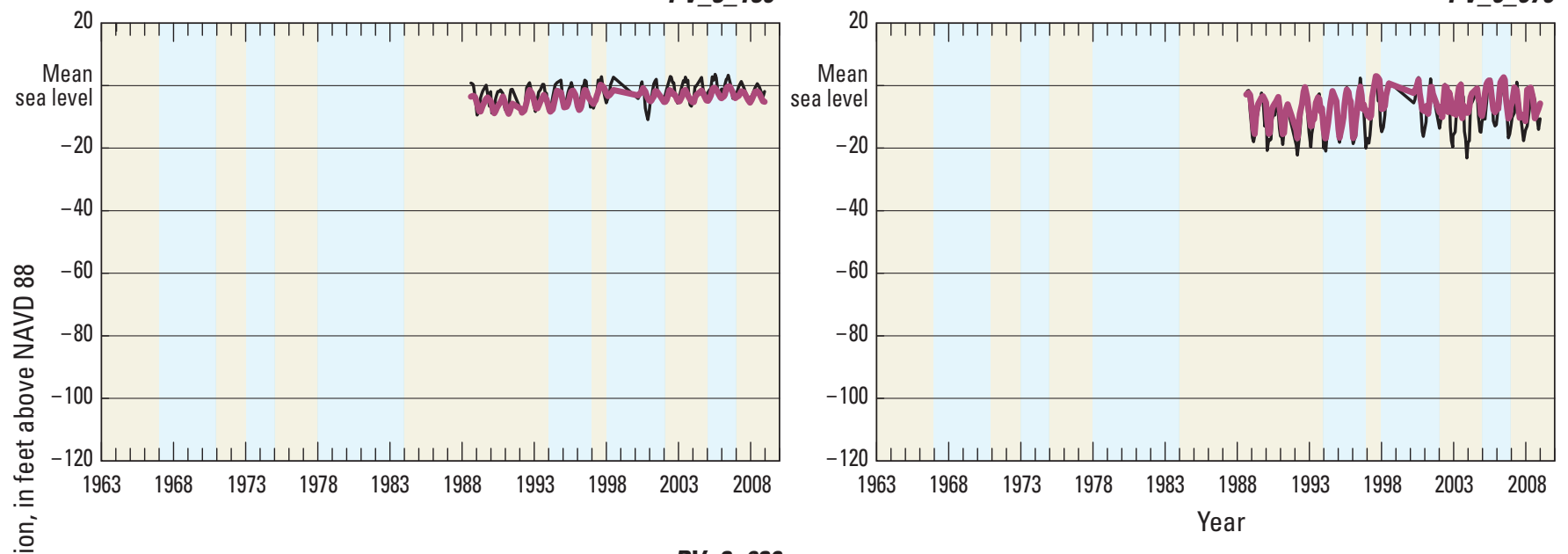

PV 3630

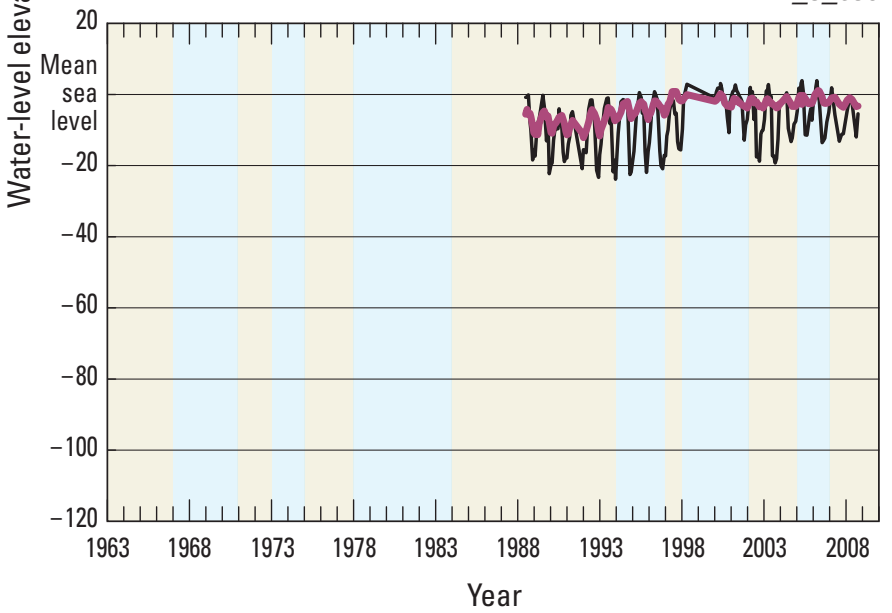

EXPLANATION

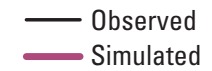

See figure 28 for location of wells

Recent precipitation cycles

Dry

Wet

Figure 30. - Continued 
E Monterey County Coastal (Non-CDS)
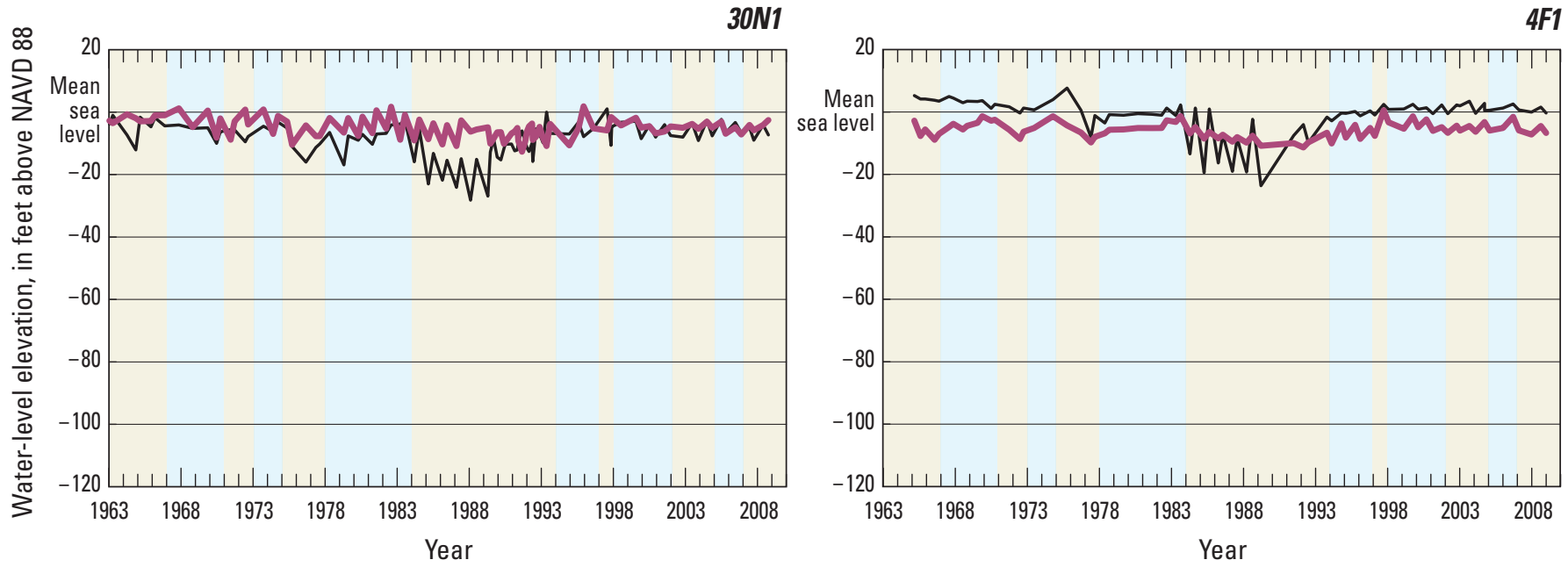

$\boldsymbol{F} \quad$ Monterey County Coastal (CDS)
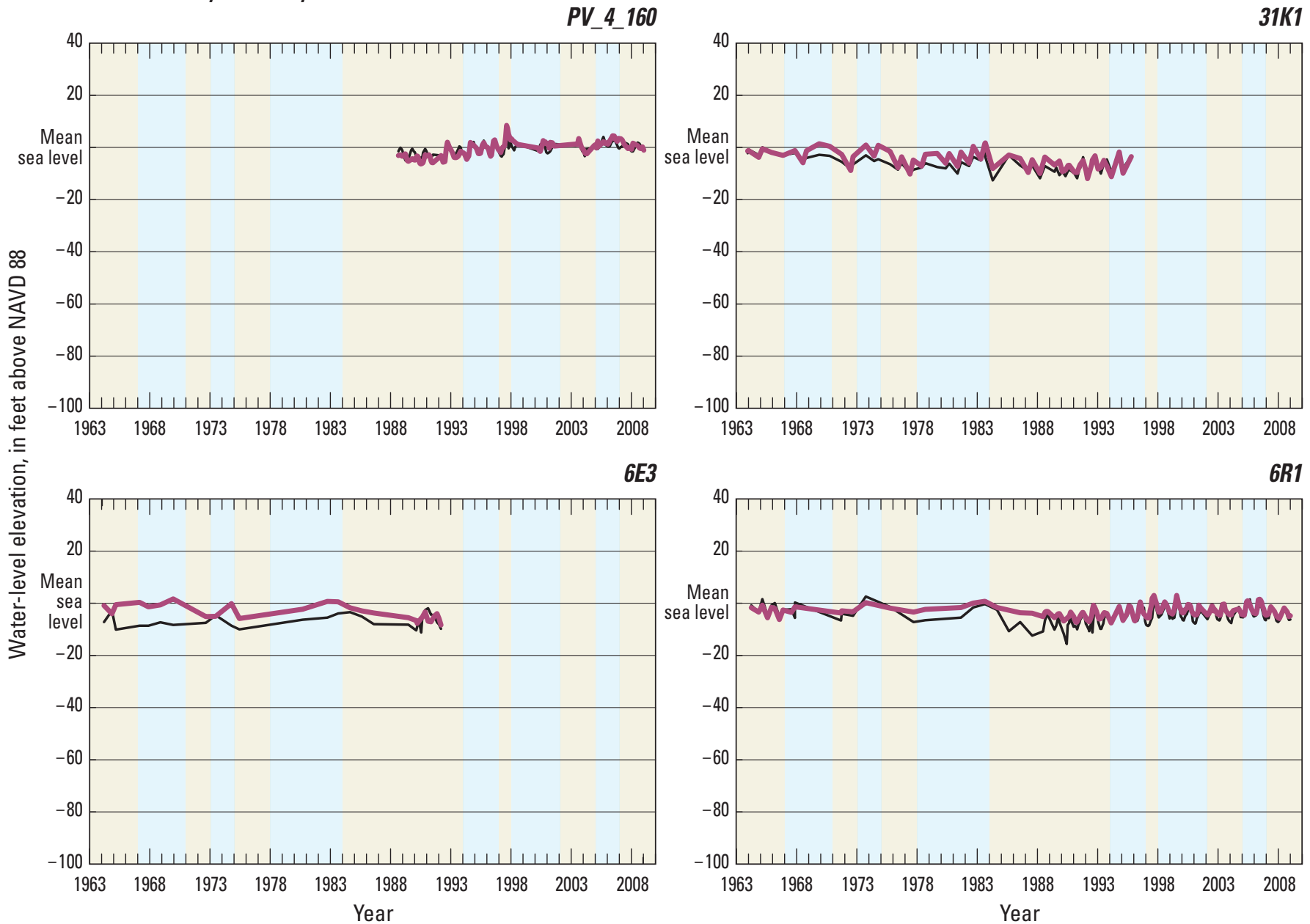

EXPLANATION

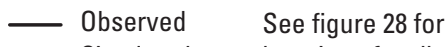

location of wells

Recent precipitation cycles

Figure 30. - Continued 


\section{G Santa Cruz County Monitoring Wells}

SC A2A

$S C \_A 2 C$
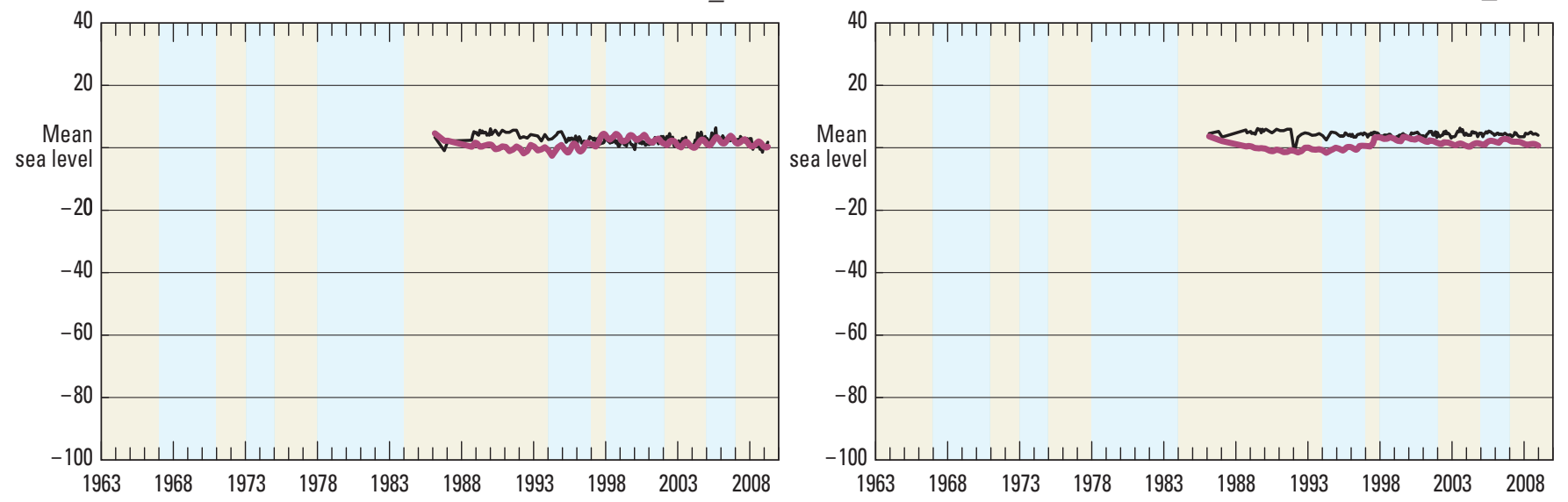

$S C \_A 3 A$
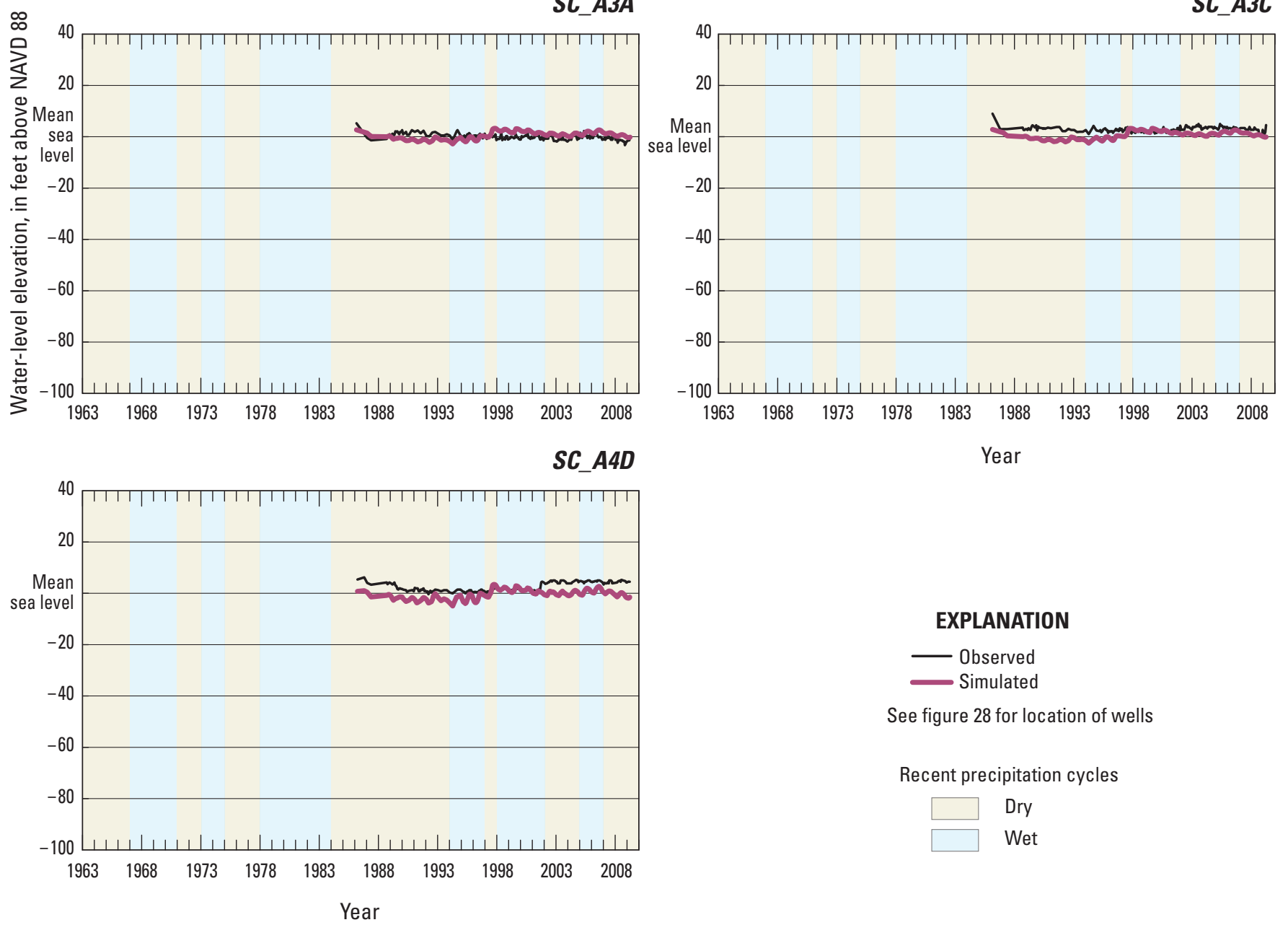

See figure 28 for location of wells

Recent precipitation cycles

Dry

Wet

Figure 30. - Continued 

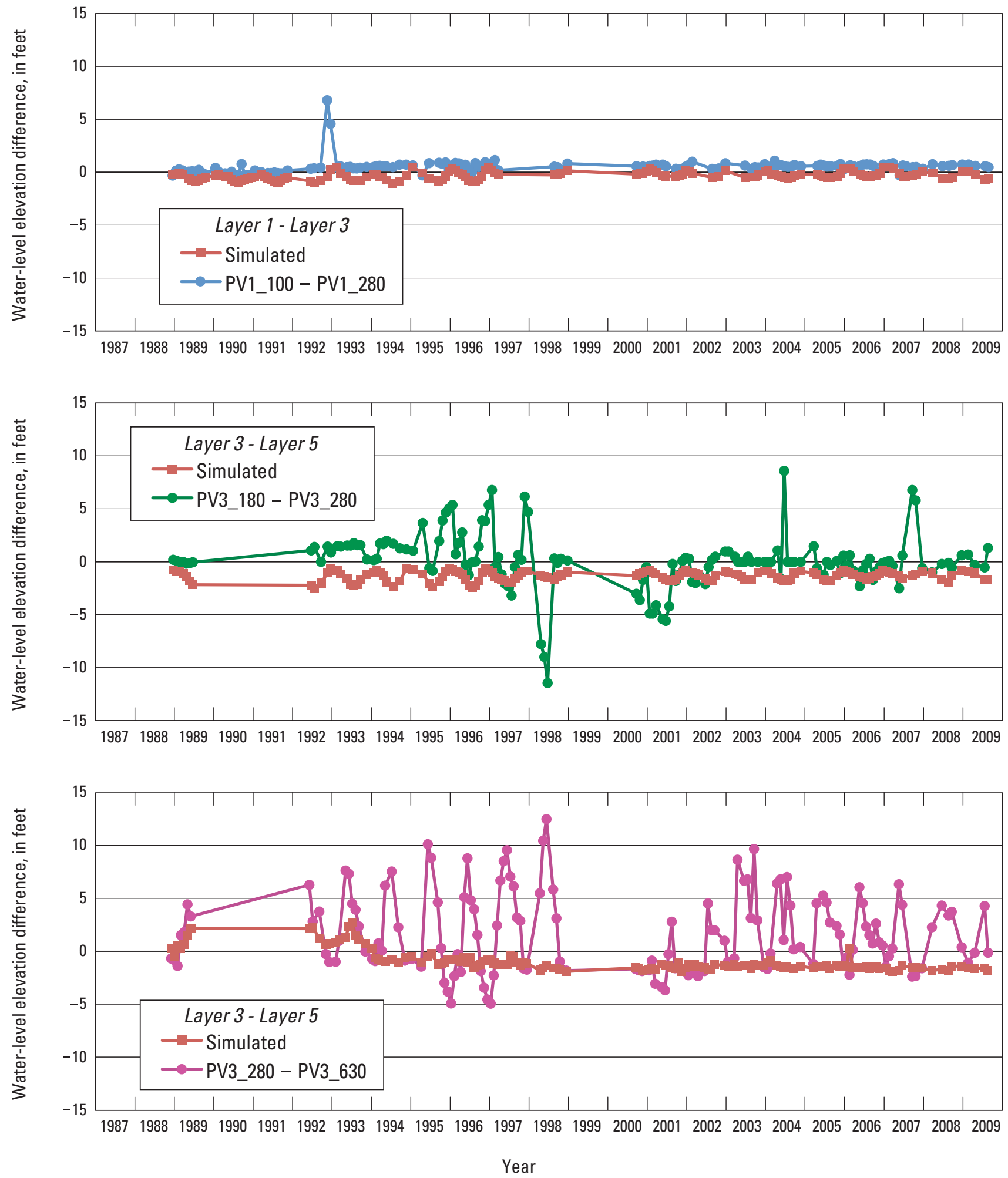

Figure 31. Simulated and measured hydrographs of vertical water-level differences for selected monitoring wells in Pajaro Valley, California. 

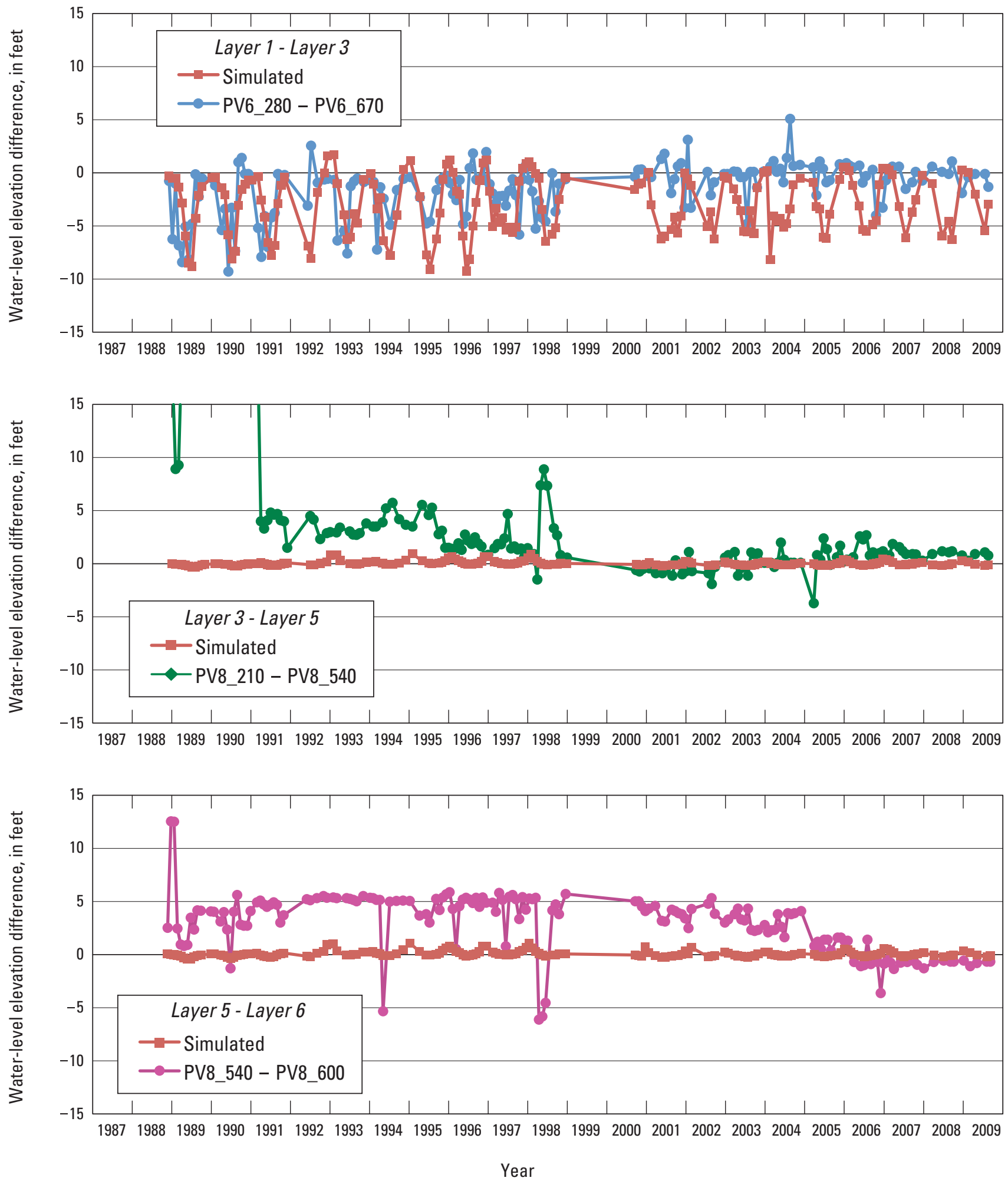

Figure 31. - Continued 

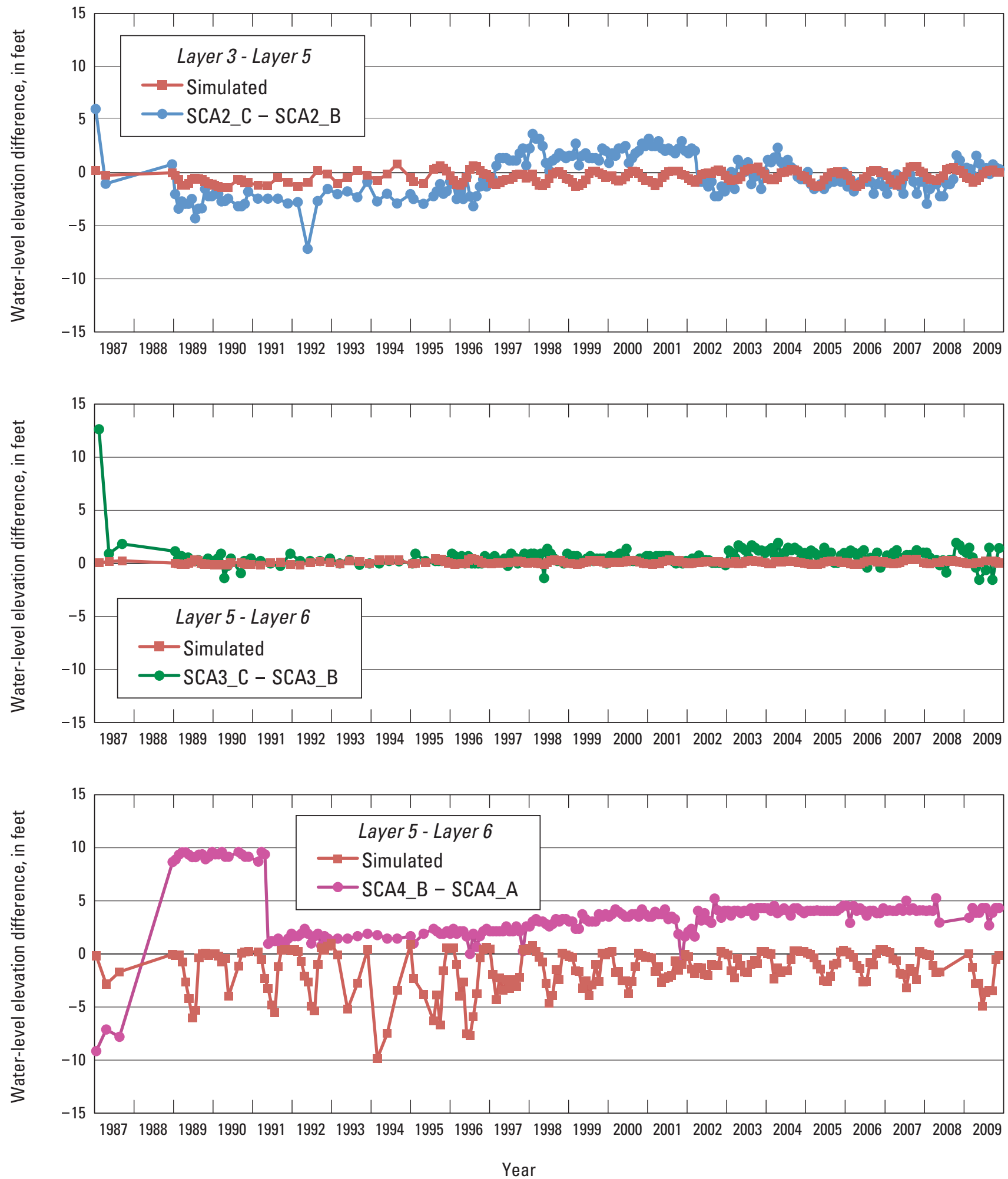

Figure 31. - Continued 

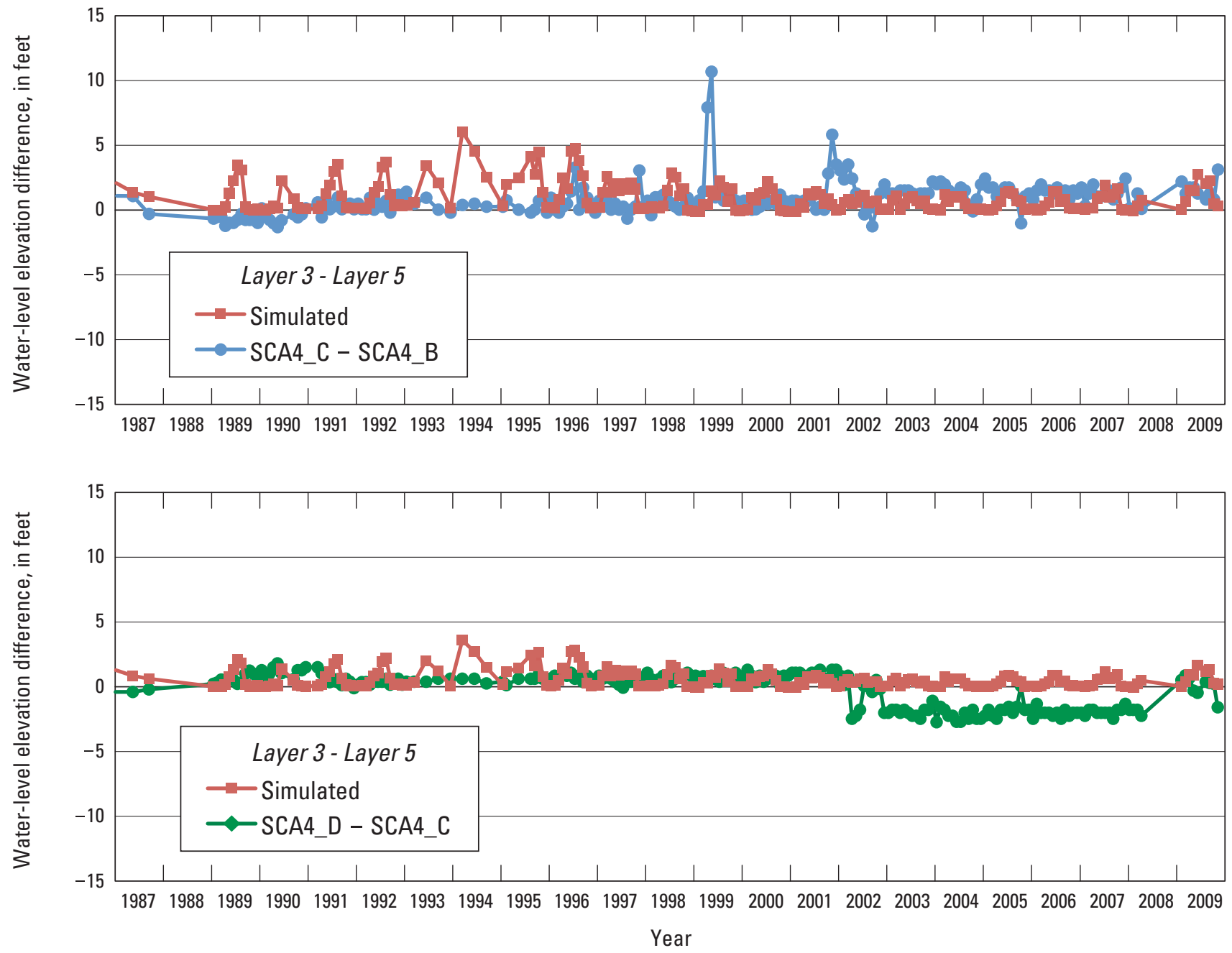

Figure 31. - - Continued 


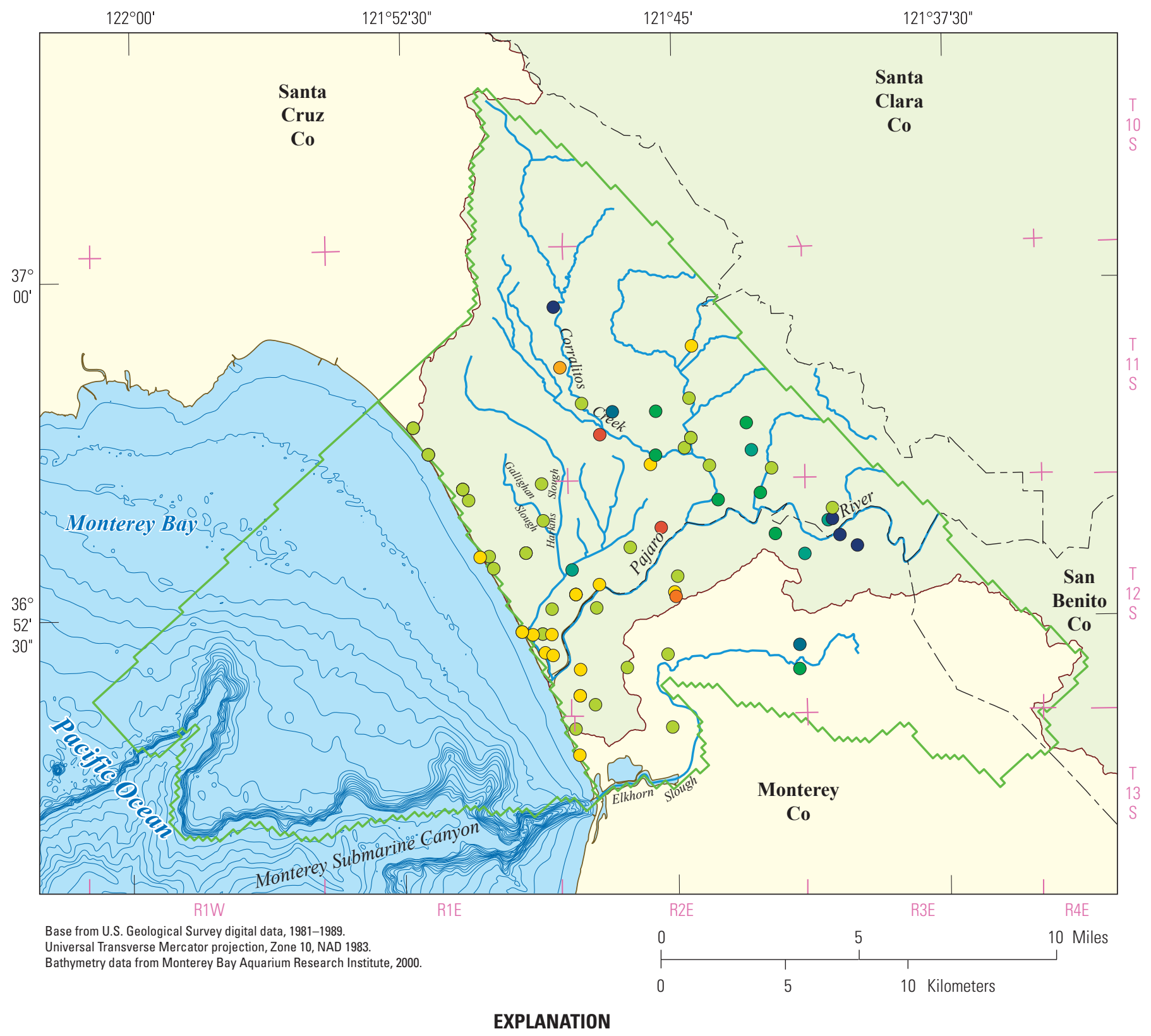

\begin{tabular}{|lrr}
\hline Pajaro River watershed & Average residual by well \\
& 0 & -25.2 to -15.0 \\
Outside Pajaro River & 0 & -14.9 to -10.0 \\
watershed & 0 & -9.9 to -5.0 \\
& 0 & -4.9 to 0.0 \\
Model grid boundary & 0 & 0.1 to 5.0 \\
River or streams & 0 & 5.1 to 10.0 \\
Bathymetry & 0 & 10.1 to 15.0 \\
contours & 0 & 15.1 to 20.0 \\
& 0 & 20.1 to 25.0 \\
& 0 & 25.1 to 30.0
\end{tabular}

Figure 32. Average residual at observation wells for the calibrated transient groundwater flow model throughout the Pajaro Valley. 


\section{Groundwater-Level Maps}

Simulated heads from the PVHM were spatially compared with water-level maps for the Pajaro Valley aquifer for: 1987(during the drought of the late 1980s); 1992 (just after the drought); 1998 (after the subsequent wet period); and September 2006 (Pajaro Valley Water Management Agency, 2007). The simulated groundwater levels are in general agreement with the hand-contoured water-level maps for these periods (fig. 33). The thematic pixels from the simulated water levels are a thickness-weighted average of simulated water levels that represent the Purisima Formation, the upper and lower Aromas, and the Alluvium combined with the Aromas where the alluvium crops out. The thickness-weighted average was used because this is consistent with the averaging in the observation package (HOB) in MF-FMP2, the composite water levels derived from wells that were used to create the hand-contoured water-level maps by PVWMA, and the composite simulated water levels derived from the HOB package (Hill and others, 2000; Harbaugh, 2005). The waterlevel maps provided additional information during the model calibration on the effects of inland and coastal boundary flows, and guided adjustments to selected hydraulic properties such as vertical hydraulic conductivities.

The sequence of contoured measured water levels and simulated thematic maps indicate regions in the center of Pajaro Valley in which water levels are below the equivalent freshwater heads above sea level required to avoid seawater intrusion by about 4 to $12 \mathrm{ft}$ for the Upper Aromas, $10 \mathrm{ft}$ for the Lower Aromas, and 5 to $15 \mathrm{ft}$ for the Purisima Formation (Johnson, 1982; Bond and Bredehoeft, 1987; Mann, 1988; Hanson, 2003b, fig. 3; Hydrometrics, 2009, tables ES 1-3). The water levels below sea level in the Pajaro Valley extend from the north face of the submarine canyon across the coast at Springfield Terrace landward up the Pajaro River Valley, past the CW, to the eastern boundary of the model in 1987 (fig. 33A). Observed water levels were 10 to $20 \mathrm{ft}$ lower post- drought (1992) than they were before the drought, with water levels below sea level extending inland from the coast (fig. 33B). By 1998 the decline in water levels had propagated further offshore, did not show significant recovery in the Springfield Terrace coastal region and Pajaro River Valley, but did show some recovery east of the Zayante Fault (fig. 33C). By the fall of 2006, water levels below sea level persisted in the southern coastal region of Springfield Terrace and in the central part of the Pajaro River Valley around the CW, a pattern replicated by output of the PVHM (fig. 33D).

\section{Inland Pajaro Valley}

Overall, water levels throughout the inland Pajaro Valley are a subdued reflection of topography, ramping upwards toward the foothills of the headlands of the Santa Cruz
Mountains (figs. 2A, 33). Water levels in most of the inland area are influenced by the confining layers in the alluvium and the Aromas, which separates the upper semi-confined portions of the alluvium, Aromas, and Purisima aquifers from their distal confined regions of these aquifers (figs. 24, 27). Water levels in wells close to streams and rivers reflect unconfined to semi-confined conditions, with fluctuations generally less than $20 \mathrm{ft}$, and show only subdued variations that are driven by interannual climatic effects (figs. 30A, B). Streams and rivers along the edges of the basins are generally losing water, and vertical hydraulic gradients in these predominantly recharge areas are downward. These areas have been dominantly rural, with land use characterized by apple orchards and native vegetation and, in more recent years, canopied cane berries. As such, the area has limited municipal and rural residential pumpage, and includes some dry-land farming owing to the relatively abundant precipitation and shallower groundwater near rivers and streams.

\section{Coastal Pajaro Valley}

In the coastal regions of Pajaro Valley (fig. 2B), the vertical head differences are relatively small (less than $10 \mathrm{ft}$ ) and the vertical hydraulic gradients are generally downward (fig. 31), while horizontal gradients in the upper system are landward (fig. 33). Water levels in most of the coastal area are influenced by the confining layers in the alluvium and the Aromas, which separate the confined portions of the alluvium, Aromas, and Purisima aquifers from each other (figs. 24, 27). However, large parts of the Alluvial aquifer system are unconfined to semi-confined even in coastal regions. The presence of similar water-level fluctuations in the different aquifers indicates that some limited pressure changes may be transmitted between aquifers. These hydraulic connections between confined aquifers could reflect wellbore flow in multi-aquifer wells and limited vertical flow in areas where the confining units are estimated to be missing or less finegrained (fig. 27). In the northern and southern coastal regions, the coastal water levels show relatively small (less than $10 \mathrm{ft}$ ) annual and interannual fluctuations (figs. 30C, E, F, G). In the confined regions of the central coastal areas and the Pajaro River valley in Santa Cruz County (fig. 30D), water levels show relatively larger annual fluctuations (10-25 ft) owing to agricultural pumpage, but still show subdued interannual fluctuations that would be driven by climate variations in recharge or demand for pumpage. Water levels in the wells in the northern coastal region have hydrograph signatures (peaks and troughs) which reflect the effect of wet and dry precipitation cycles, and seasonal fluctuations ranging from about 5 to $10 \mathrm{ft}$. Toward the south in Springfield Terrace and Monterey Submarine Canyon, water levels decline slightly or remain relatively constant, as indicated by the hydrographs (figs. 30E, F) and water-level maps (fig. 33). 


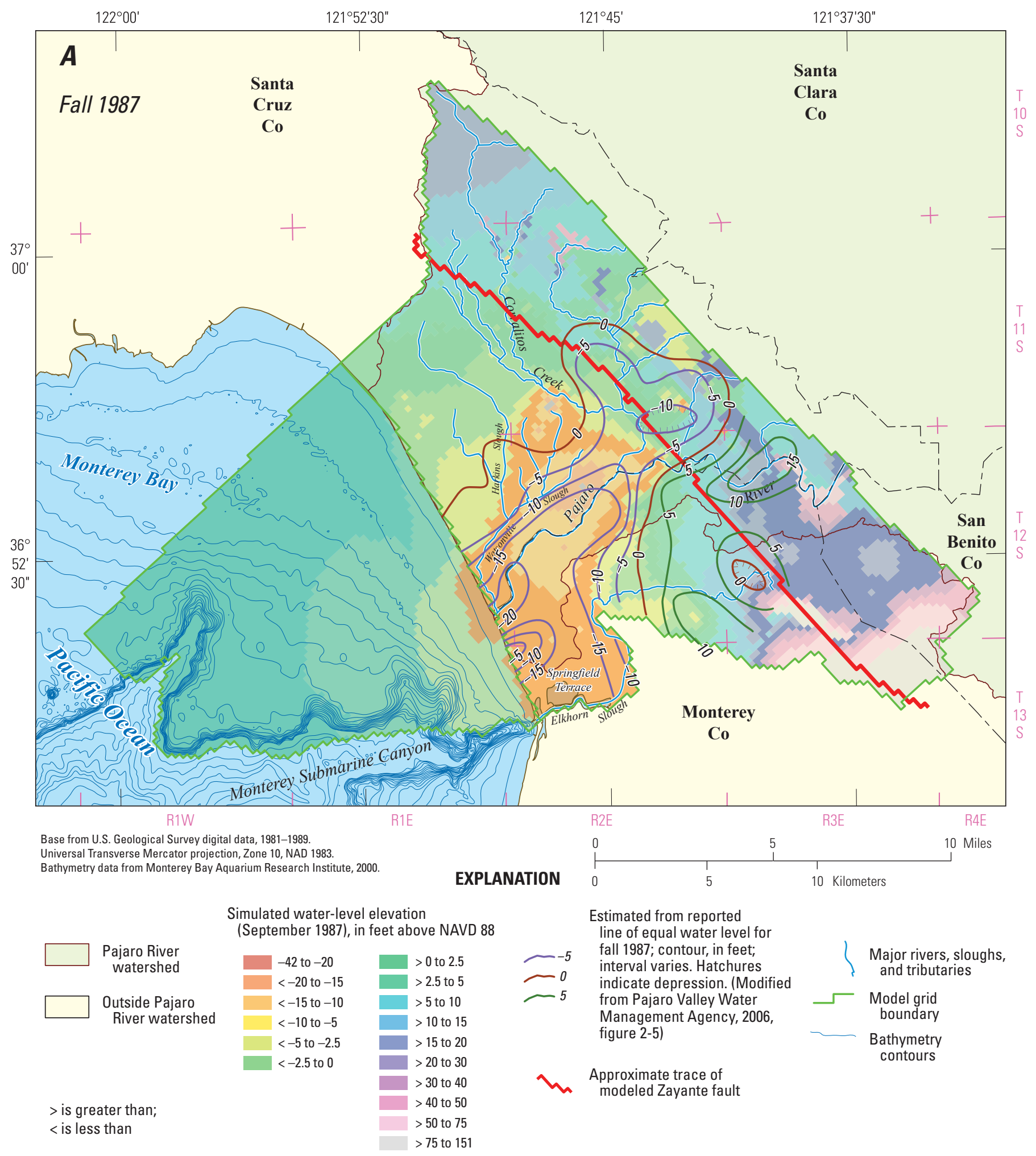

Figure 33. Comparison of the contoured measured with simulated water levels $A$, in 1987; $B$, in 1992; $C$, in 1998; and $D$, in September 2006 for the calibrated hydrologic flow model, Pajaro Valley, California. 


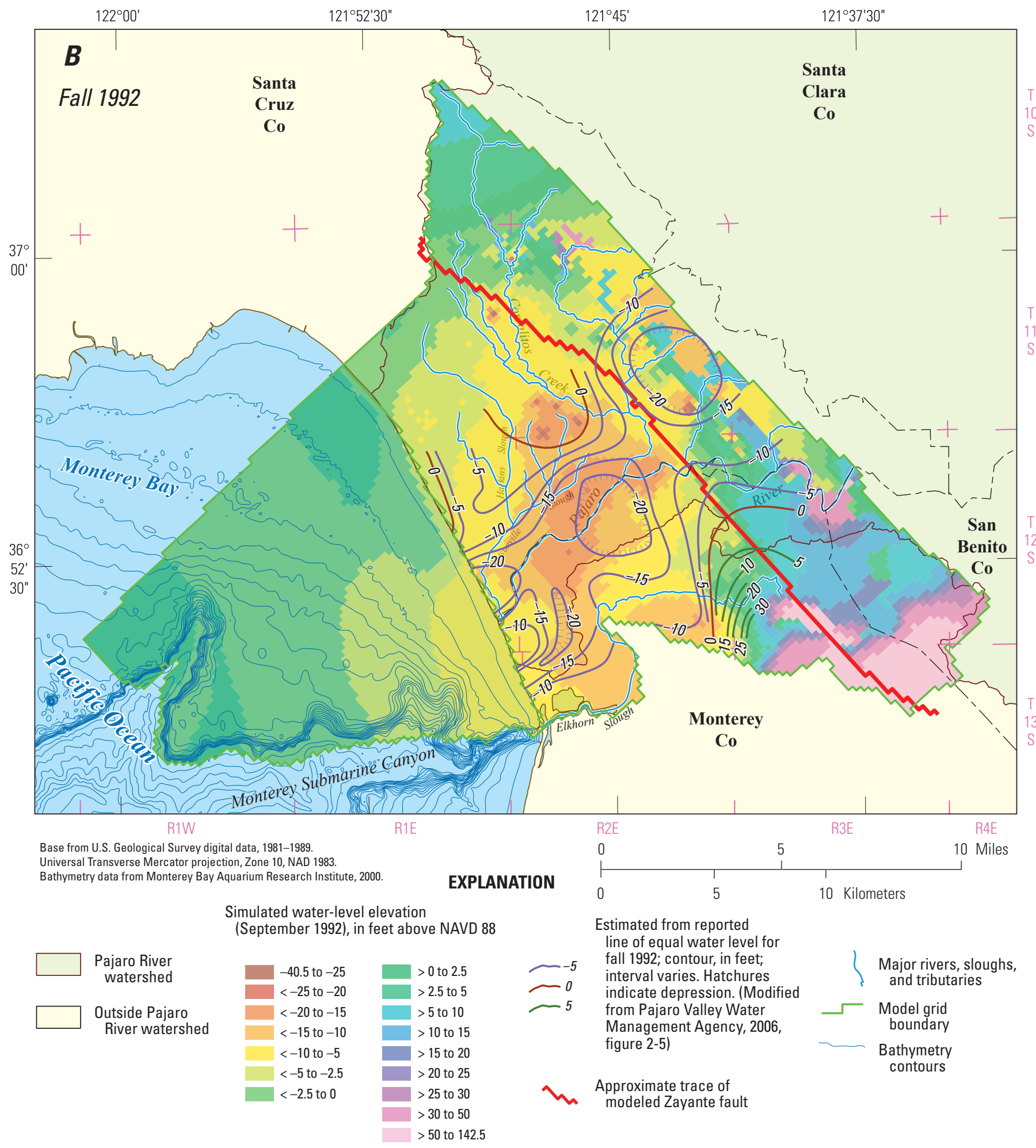

Figure 33. - Continued 


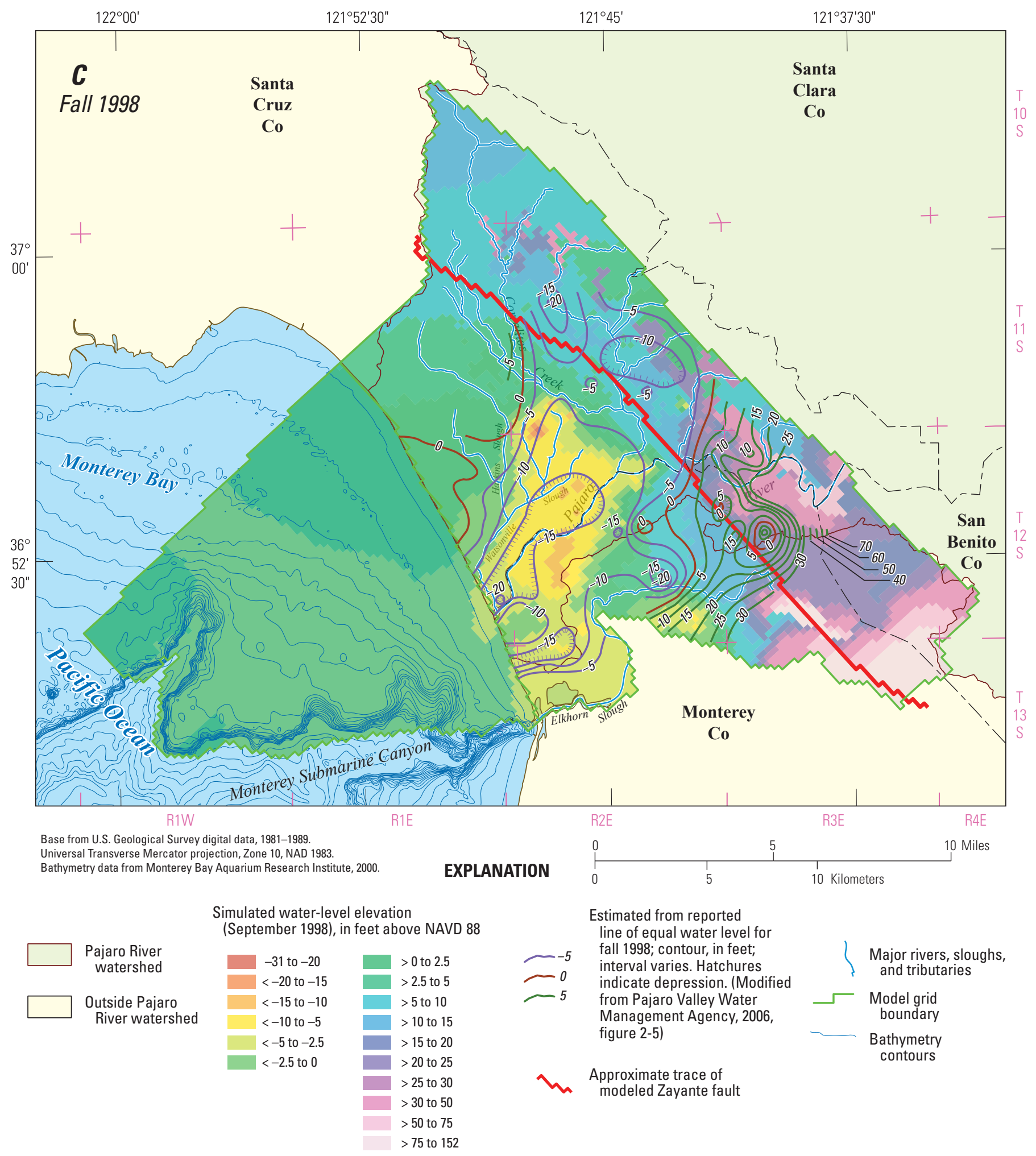

Figure 33. - Continued 


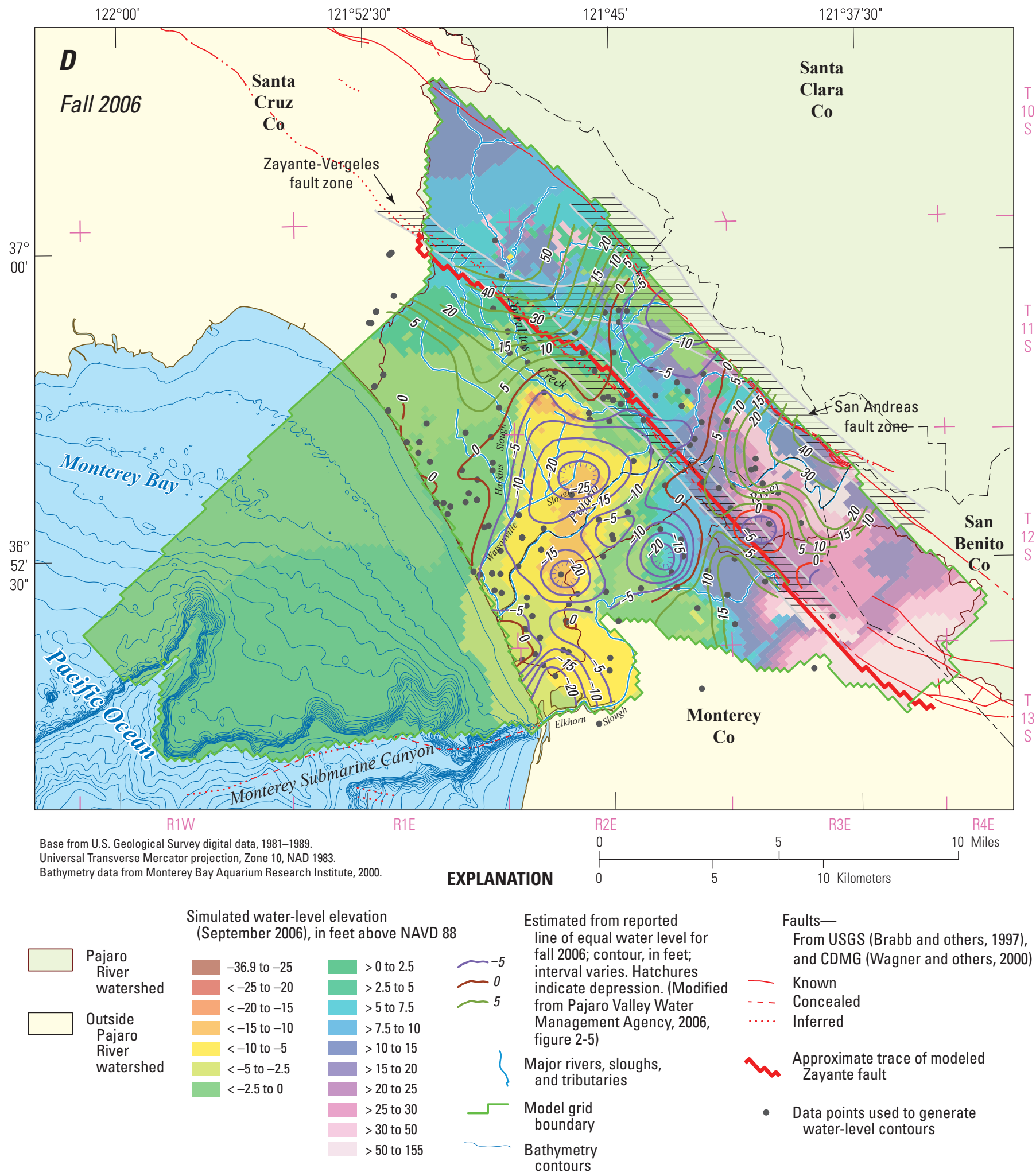

Figure 33. - Continued 


\section{Streamflow Observations}

Groundwater levels were supplemented with streamflow observations to provide additional constraint on the fit of the regional hydrologic model. Streamflows from USGS stream gaging stations on Corralitos Creek at Corralitos (11111591) for 1963-72 (110 monthly observations) and on Corralitos Creek at Freedom (11111592) for the entire period of simulation (555 monthly observations) were compared with simulated values. Other selected reaches of Corralitos Creek and for the Pajaro River at Murphy's Crossing have only been available since about 2000 (Andrew Fisher, written commun., 2007). Monthly observations included 52 at Murphy's Crossing on the Pajaro River downstream from Chittendon, 44 on the Corralitos Creek at BV, 48 at VR, 46 below the streamflow diversion on the West Branch of the Corralitos Creek, and 48 below the streamflow diversions on Brown's Creek. In addition, the diversions themselves represent a form of downstream gage and provided 401 nonzero monthly observations from diversions on the West Branch of Corralitos Creek and 423 monthly observations of diversions on Brown's Creek for the period of simulation. Finally, 170 monthly observations of streamflow differences were used to approximate gains and losses of streamflow between these gages for the last few years of the simulation, including 30 observations between BV and VR Bridges, 40 observations between the diversions and BV Bridge, 48 observations between VR Bridge and the USGS gaging station CF, and 52 observations between Chittendon and Murphy Crossings on the Pajaro River.

Measured and simulated streamflows show a similar range (fig. 34). The simulated flows for Corralitos Creek are about a factor of 10 less than observed flows during the summer and fall months at Corralitos and VR Bridge but are more nearly comparable at BV Bridge and at CF (fig. 34A). The streamflow at Murphy's Crossing shows a similar range, with some simulated summer and fall values greater than measured values (fig. 34A). Similarly, the simulated diversions are comparable to reported diversions for most summer months on Corralitos Creek and selected summer months at BV (fig. 34B). These differences may be an artifact of the potential underestimation of stream inflows that was carried over from the previous PVIGSM model. The simulation of reported diversions for Harkins Slough, which are totally dependent on simulated overland runoff from the Farm Process into Harkins Slough, are comparable except for the slight underestimation for 2002 (fig. 23A).

Simulated streamflow losses on the Pajaro River are slightly underestimated in comparison to estimated losses between gages (fig. 34C). However, the majority of the streamflow infiltration occurs on the Pajaro River above Murphy's Crossing where the modeled and measured losses are generally comparable. The largest discrepancies between losses occur during the higher-flow months of the winter and spring, when the more recent downstream streamflow measurements greater than about $150 \mathrm{cfs}$ are absent and related estimated losses are considered highly uncertain over monthly stress periods. Apparent streamflow gains on reaches of the Corralitos Creek estimated from differences of measured streamflows may reflect contributions from other sources of water, such as overland runoff and rejected infiltration from the shallow perched layer. Such contributions could represent the gaining periods, with streamflows from rejected infiltration that are not simulated as part of the model structure, which in turn yield some of these observations more uncertain. The spatial distribution of losing and gaining reaches is generally consistent with the observed reaches and indicates that most of the losses occur in the uppermost reaches of the tributaries, along selected central reaches of Corralitos Creek, and along the Pajaro River just above and immediately below Murphy's Crossing (figs. 28, 35).

\section{Pumpage Observations}

Reported pumpage for the period 2002 through 2009 was available for the water-balance subregions, with the most reliable pumpage information spanning the period 2006-09. Totals of reported agricultural pumpage were compared with agricultural pumpage estimated through the simulation of water consumption by the Farm Process used in the PVHM. A total of 480 agricultural pumpage estimates representing seasonal periods from 17 of the WBS regions were used as additional calibration targets for the PVHM

Simulated and reported total agricultural pumpage are compared for the 17 WBSs (fig. 36A). The model slightly overestimates agricultural pumpage for the inland subregions of Corralitos and Highlands North. The percentages of total reported and simulated agricultural pumpage by WBS are also comparable, within a few percent, for most subregions (fig. 36B). In addition, total annual and agricultural pumpage were used as comparisons for the period 1999-2009. The annual total and total agricultural pumpage are comparable between reported and simulated values for these 11 years (fig. 36C). For the total PVHM model and for the PVWMA part of the PVHM model, the average annual differences (reported minus simulated) for total agricultural were -859 acre-ft/yr and -204 acre-ft/yr for the period 2006-09, respectively. This represents average differences of about -1.9 and less than 1 percent, respectively. Similarly, the annual differences between total reported and simulated agricultural pumpage during 2006-09 for the coastal CDS and non-CDS WBS subregions were -4 and 209 acre- $\mathrm{ft} / \mathrm{yr}$, representing less than -1.0 percent and 3.3 percent of the reported agricultural pumpage, respectively. These differences vary from season to season and year to year but were well within the range of uncertainty of the reported pumpage for this most recent four year period. 

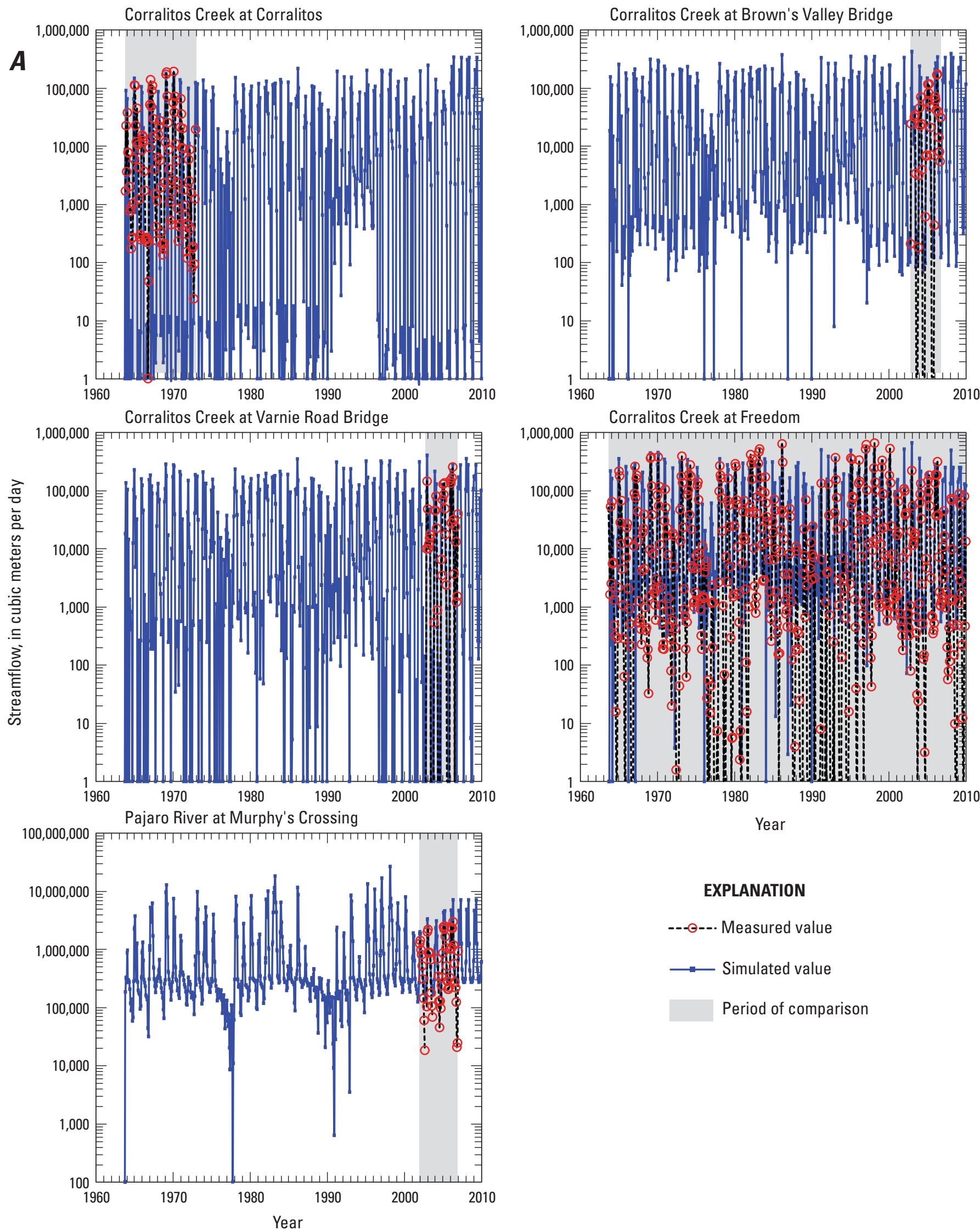

\section{EXPLANATION}

---๑--. Measured value

$\longrightarrow$ Simulated value

Period of comparison

Figure 34. Reported and simulated $A$, selected downstream streamflows; $B$, City of Watsonville upstream diversions; and $C$, selected streamflow gains and losses, Pajaro Valley, California. 

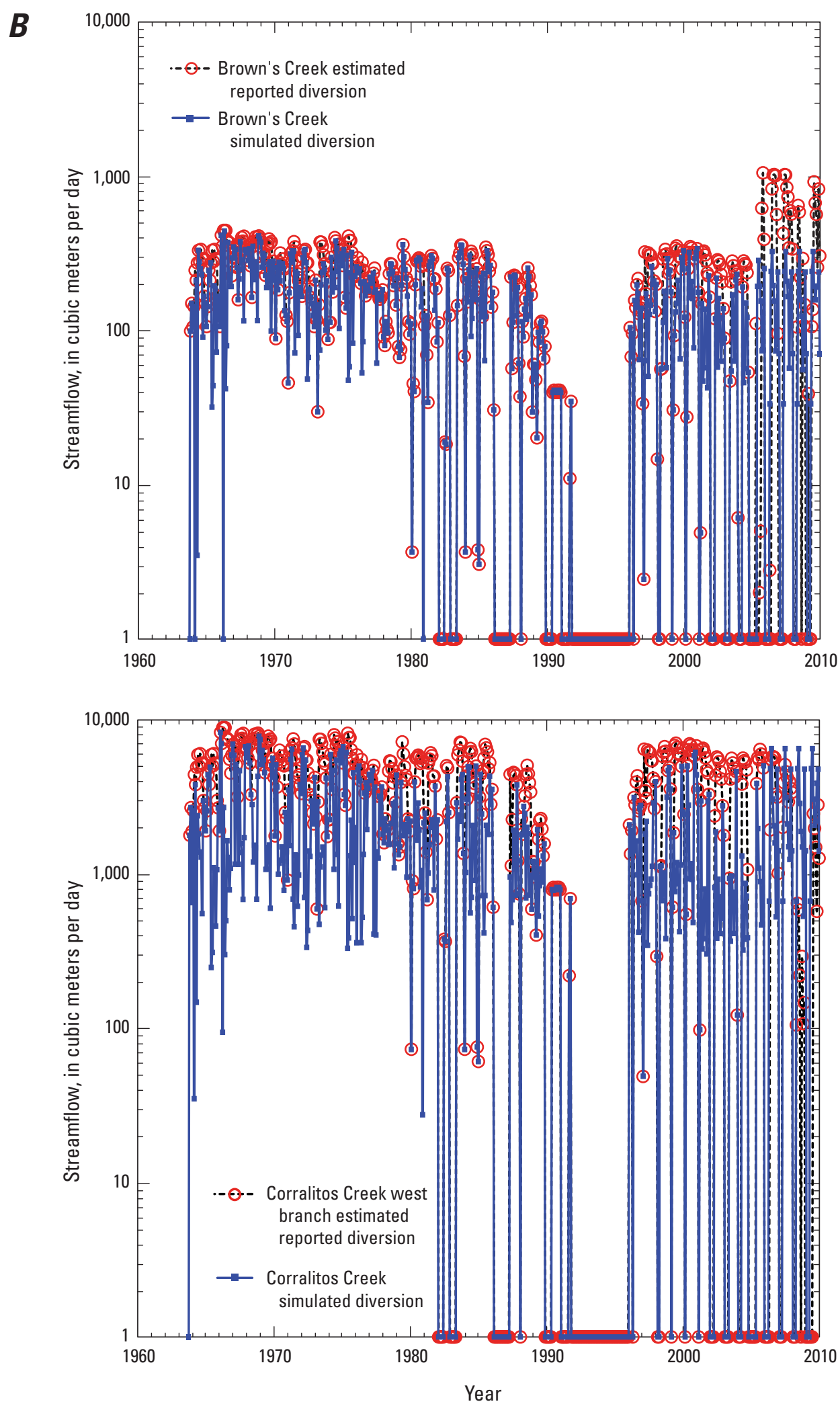

Figure 34. - Continued 

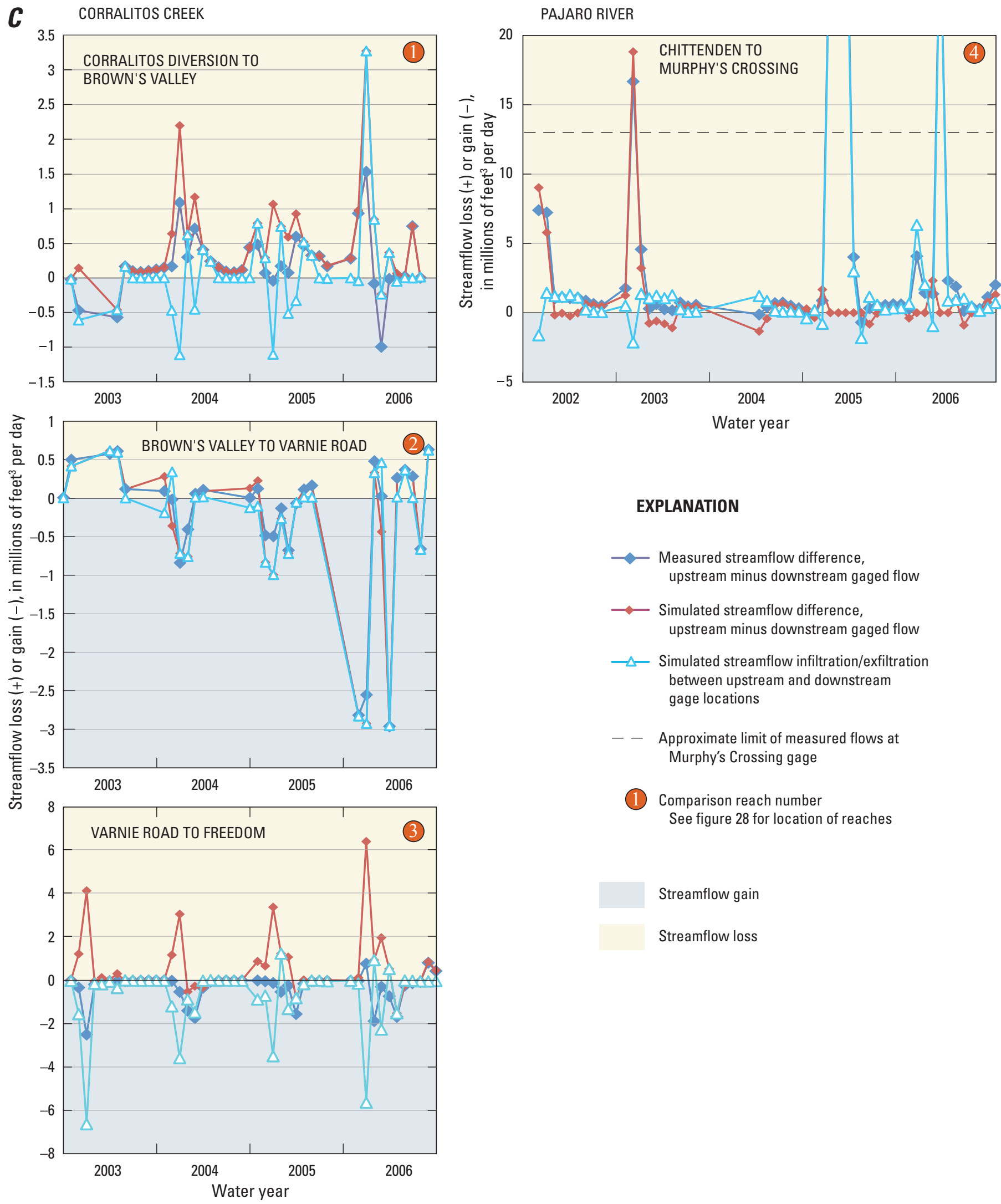

EXPLANATION

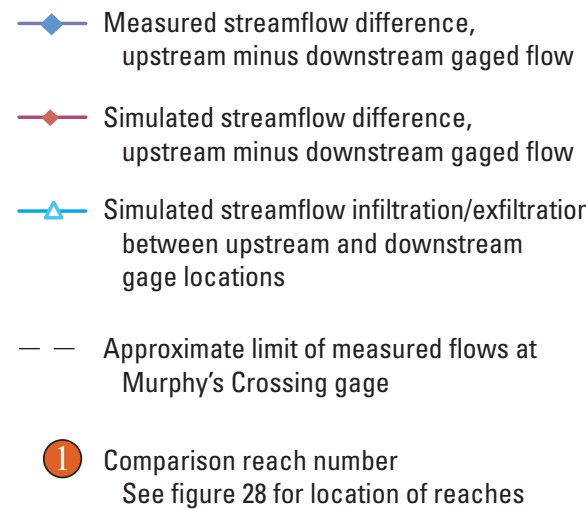

Streamflow gain

Streamflow loss

Figure 34. - Continued 


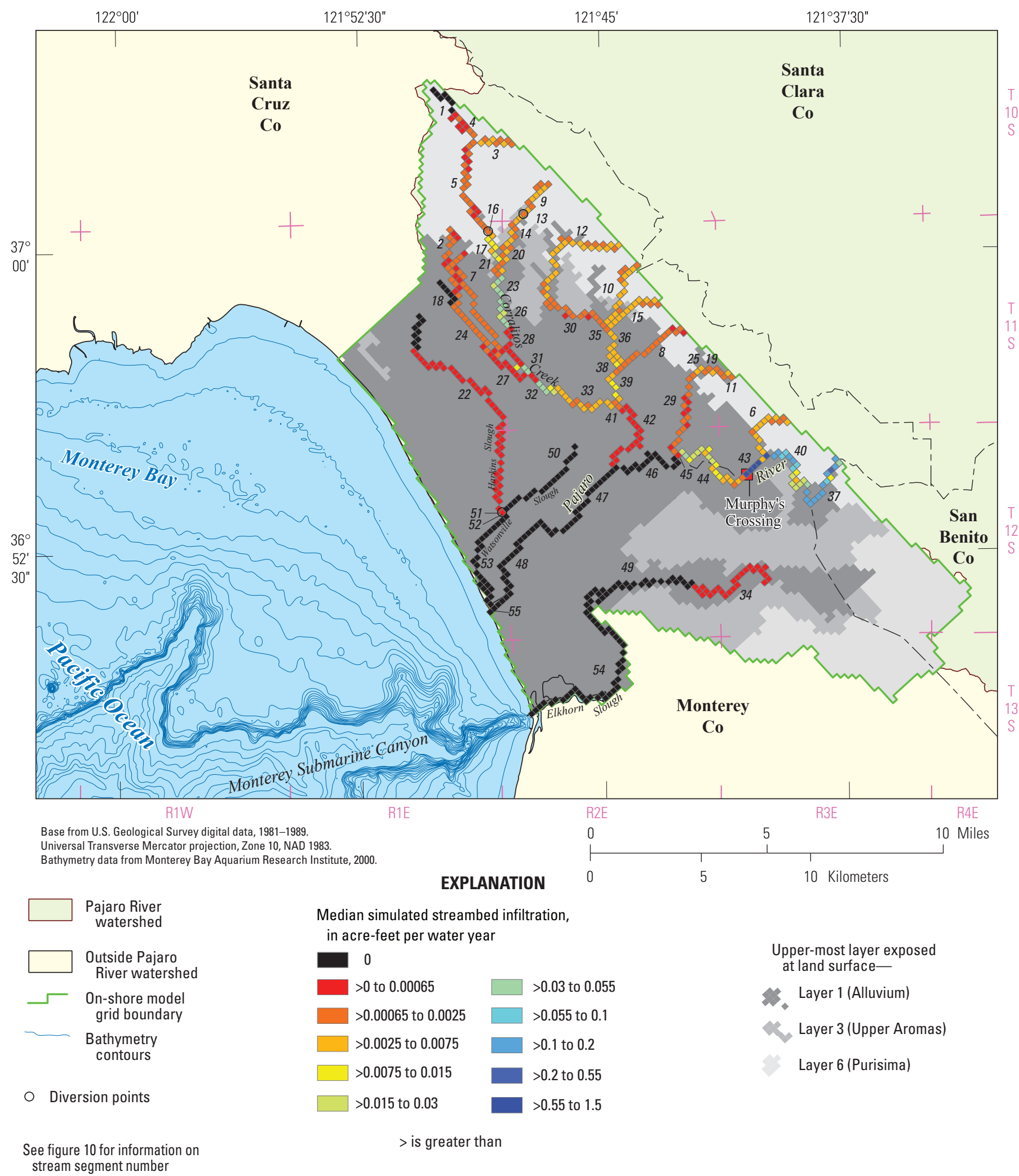

Figure 35. Distribution of median streamflow loss by stream segments for the Pajaro Valley, California. 
$\boldsymbol{A}$

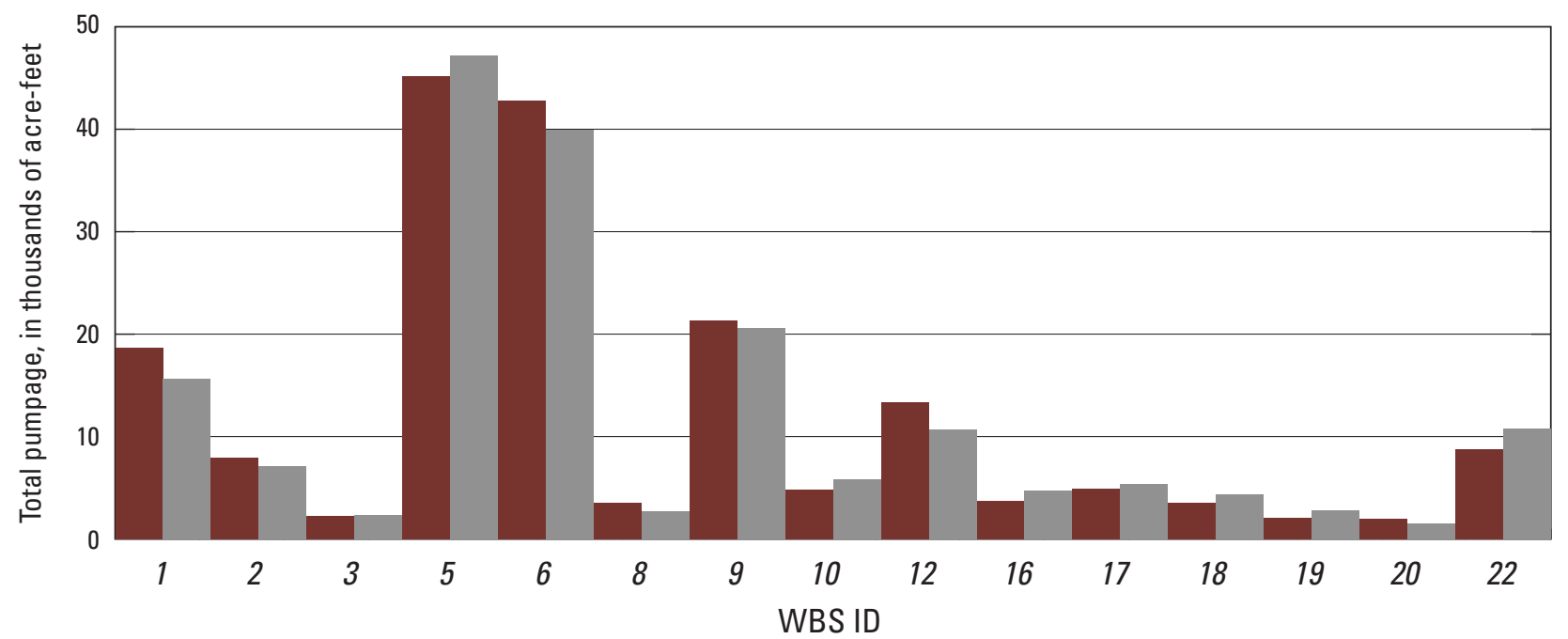

EXPLANATION

Total agricultural

WBS ID Water balance subregion (WBS) pumpage 2006-09

- Simulated

1 Corralitos

Harkins Slough

San Andreas

Highlands North

- Reported

Salsipudes

Andreas (CDS)

17 Beach Road (CDS)

18 Springfield Terrace E (non-CDS)

Pajaro

$8 \quad$ Pajaro River Mouth (CDS)

19 Springfield Terrace W (non-CDS)

20 Springfield Terrace SE (non-CDS)

10 Beach Road

Figure 36. $\quad A$, Total reported and simulated pumpage for each water-balance subregion for the period 2006-09; $B$, percentages of measured and simulated agricultural pumpage for 2006-09; and $C$, total annual and total annual agricultural reported and simulated pumpage from 2002-09, Pajaro Valley, California. [CDS, coastal distribution system] 
B
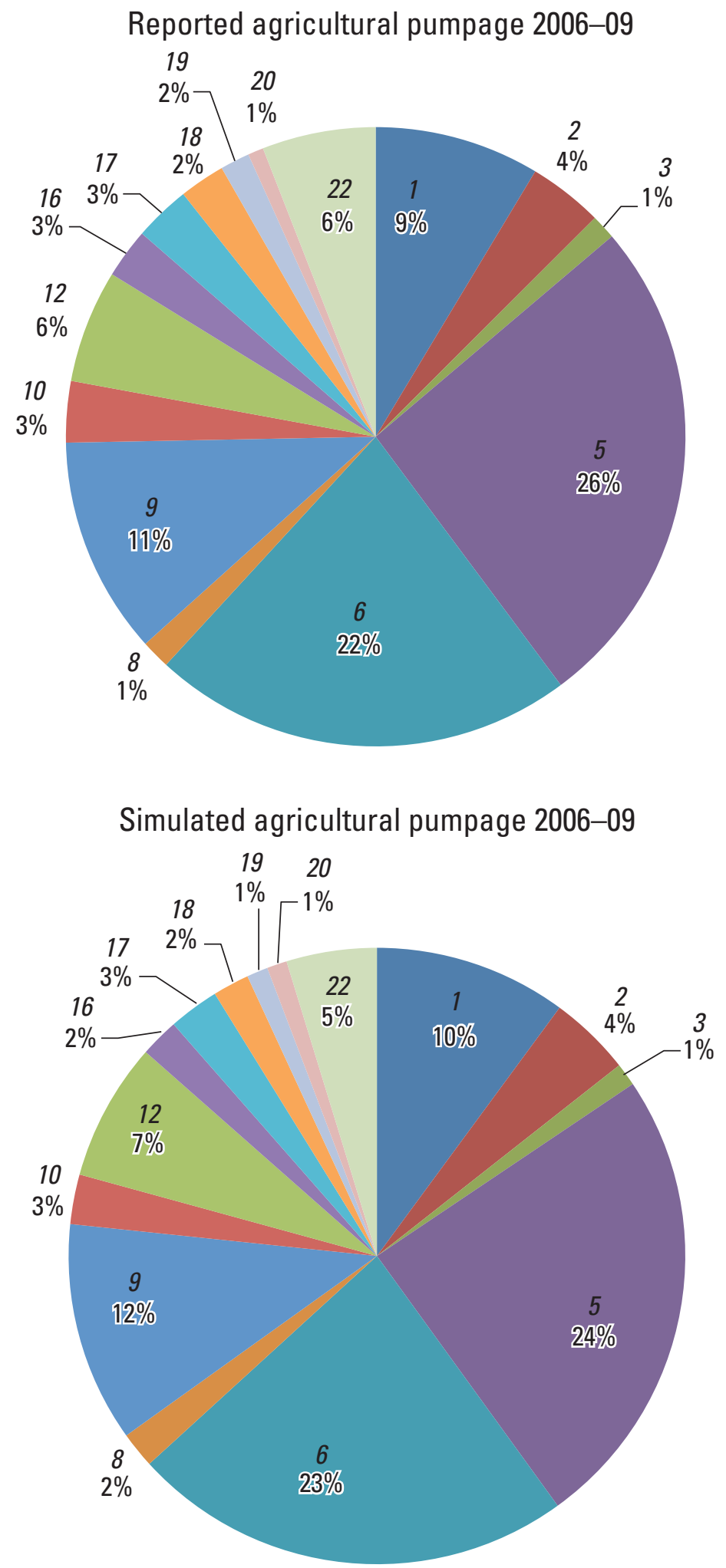

\section{EXPLANATION}

WBS ID Water balance subregion

1 Corralitos

2 Harkins Slough

3 San Andreas

5 Salsipudes

6 Pajaro

8 Pajaro River Mouth

9 Springfield Terrace

10 Beach Road

12 Highlands North

16 San Andreas

17 Beach Road

18 Springfield Terrace E

19 Springfield Terrace W

20 Springfield Terrace SE

22 San Andreas

Figure 36. - Continued 


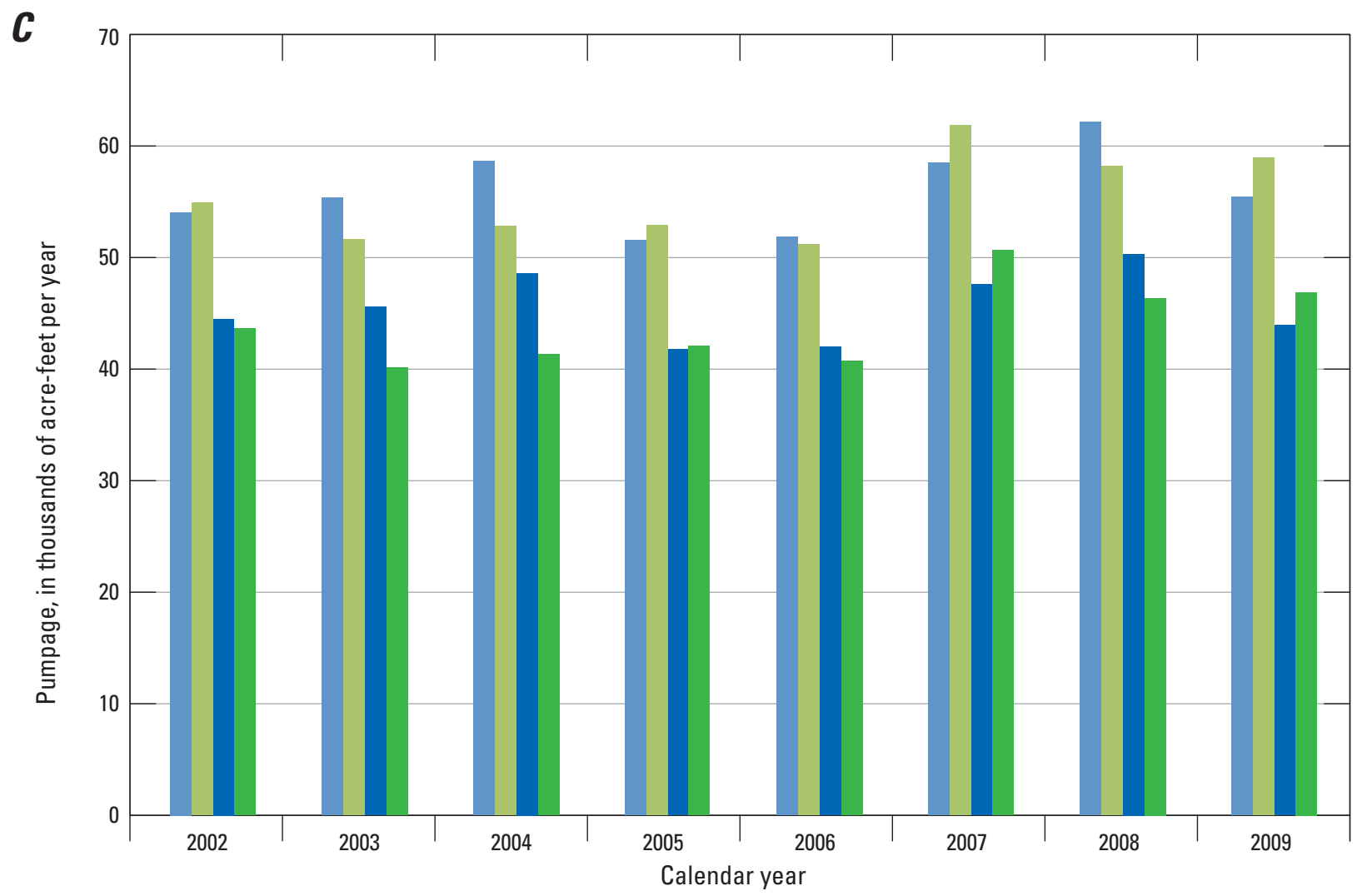

EXPLANATION

Total pumpage-

- Reported from Pajaro Valley Water Management Agency (PVWMA)

- Simulated in the PVWMA region of the Pajaro Valley Hydrologic Model
Total agricultural pumpage-

- Reported from PVWMA

- Simulated in the PVWMA region of the Pajaro Valley Hydrologic Model

Figure 36. - Continued 
Changes in simulated agricultural pumpage between wet and dry years of as much as 44 percent between 1997 (dry year) and 1998 (wet year) are also comparable to reported changes for more recent years, such as a 14 percent decrease between 2004 (dry year) and 2005 (wet year). Within the PVWMA, the simulated agricultural pumpage has declined from about 48,500 acre-ft/yr during the peak years (1984-97) to about 43,500 acre-ft/yr (1998-09). The reduced agricultural pumpage may reflect changes in land use towards more efficiently grown crops and declines in the acreage of some crops with high water demands, including vegetable row crops from 12 to 9 percent and orchard crops from about 7 to 3.5 percent of total land use (fig. 18C).

The water use within the coastal water balance region includes subregions that are served by the CDS and subregions that remain dependent on groundwater for agricultural water supply. The reported and simulated deliveries for the CDS were compared for each of the subregions that are receiving deliveries during 2006-09. The total deliveries for the entire CDS represent deliveries from recovery-wells from the HS-ASR system, as well as from supplemental wells and city-well pumpage. Simulated water deliveries for the total CDS and for individual WBSs are generally consistent with reported values (fig. 37).

A comparison of simulations with and without CDS deliveries suggests that net groundwater pumpage might be reduced by tens to hundreds of acre-ft/yr per WBS through use of this system Once the CDS is in full operation, the aggregate reduction in net pumpage could exceed 7,000 acre-ft/yr, if there were sufficient supplies of water available for CDS delivery. This would be equivalent to about 16 percent of the 54.6 million $\mathrm{m}^{3}$ (44,230 acre-ft) average agricultural pumpage for the period 2004-08, prior to the deliveries from the RWTF in the CDS (Hanson and others, 2010). The potential CDS deliveries could supply 83 percent of the 2006-09 agricultural pumpage for the current four water balance subregions receiving CDS deliveries or 38 percent of the agricultural pumpage in non-CDS coastal regions Water-Delivery Observations if there is no disparity between the timing of supply and demand.

\section{Water-Delivery Observations}

While water-delivery observations were not used as calibration targets, they provide additional insight into the ability of PVHM to simulate the supply and demand components of water use and movement across the landscape of Pajaro Valley. The delivery of water through the CDS to collectively supplant coastal groundwater pumpage for several of the subregions provides another measure of how water is being used from these alternative sources. The performance of the water delivery system (fig. $23 B$ ) suggests that the PVHM model is capable of simulating conjunctive use from supply-constrained and demand-driven water supply as a potential replacement to coastal pumpage with a climatically variable source, variable priority of sources, and a variable agricultural demand on a monthly basis (Hanson and others, 2010). However, other factors besides simple supply-anddemand relations can affect the use of wells, such as operation of supply wells including hours and rates of operation can affect the supply and demand relations. For example, during August through October 2004, simulated demand-driven deliveries overestimated actual deliveries for the supplemental wells (fig. 23B). In addition, the simulated supply priorities can be changed on a monthly basis, which enables evaluation of different delivery scenarios; for example, the simulation included months that the ASR system recovery wells were out of service and the period of December through February of each year when the RWTF is not delivering water to the CDS.

\section{Model Calibration}

The Pajaro Valley Hydrologic Model was calibrated through a combination of trial-and-error adjustments and automated processes for minimizing misfits between observations and model output. The hydrologic framework and definitions of water balance zones were modified during the calibration process. The PVHM requires specification of about a hundred parameters that vary spatially and temporally, making it a challenge to optimize their estimation. As a result, parameterization was introduced to allow a limited number of parameter values to define the model inputs that still vary through space and time. Following the definition of Hill and Tiedeman (2007), parameters are model inputs of hydraulic and hydrologic properties; for the PVHM, parameters also include landscape and crop-related properties associated with FMP2. Calibration involved a systematic application of the parameter estimation method to the narrow range of possible solutions. Because some model parameters demonstrated significant correlations, parameter estimation software such as UCODE (Poeter and others, 2005) could not be used directly for all sensitivity analyses and parameter estimation. Thus, a combination of UCODE and manual adjustments were used to conduct the parameter estimation and sensitivity analyses.

Although many more parameters were defined in the model (tables 13,14), up to 62 parameters were used during the automated calibration process. These included landscape and crop-related properties, hydraulic parameters of the aquifers and multi-node wells (table 13), and streambed vertical hydraulic conductivities (table 14).

Hydraulic properties were initially assigned values on the basis of published values and earlier modeling studies, then adjusted during model calibration. Model parameters were adjusted within ranges of reasonable values to best fit historical hydrologic conditions measured in the aquifer, stream network, and landscape, such as measured groundwater levels, streamflows, and water use. 

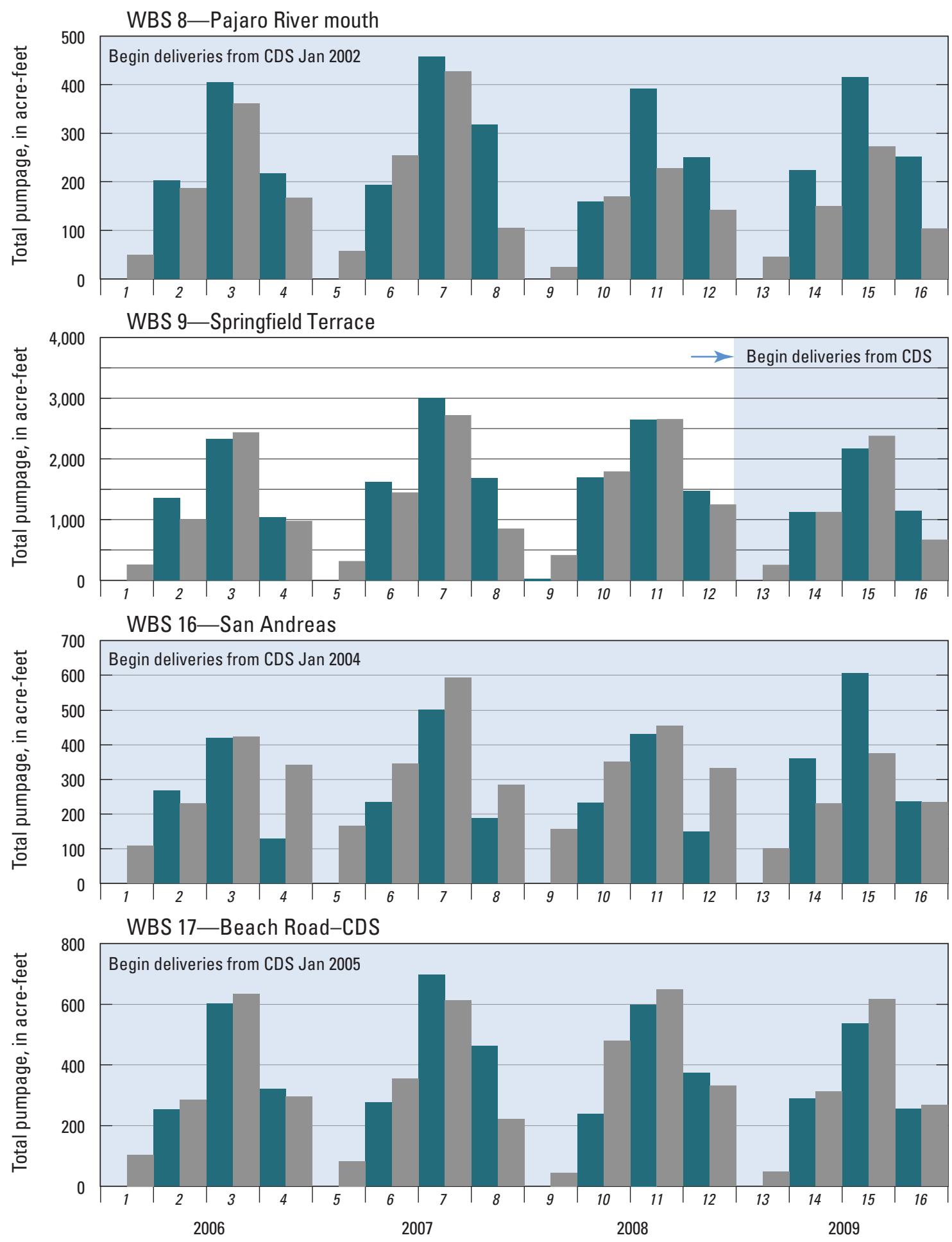

\section{EXPLANATION}

Pumpage- Period Duration

$\begin{array}{cllllllll}\text { Simulated } & 1 & \text { Jan-Mar 2006 } & 5 & \text { Jan-Mar 2007 } & 9 & \text { Jan-Mar 2008 } & 13 & \text { Jan-Mar 2009 } \\ & 2 & \text { Apr-June 2006 } & 6 & \text { Apr-June 2007 } & 10 & \text { Apr-June 2008 } & 14 & \text { Apr-June 2009 } \\ \text { Reported } & 3 & \text { July-Sep 2006 } & 7 & \text { July-Sep 2007 } & 11 & \text { July-Sep 2008 } & 15 & \text { July-Sep 2009 } \\ & 4 & \text { Oct-Dec 2006 } & 8 & \text { Oct-Dec 2007 } & 12 & \text { Oct-Dec 2008 } & 16 & \text { 0ct-Dec 2009 }\end{array}$

Figure 37. Temporal distribution of reported and simulated pumpage for the three water-balance subregions that receive water during some part of the last five years (2006-09), Pajaro Valley, California. [CDS, coastal distribution system; WBS, water-balance subregions] 
Table 14. Summary of streambed vertical hydraulic conductivity parameters and calibrated values, Pajaro Valley, California.

$[-$, not estimated $]$

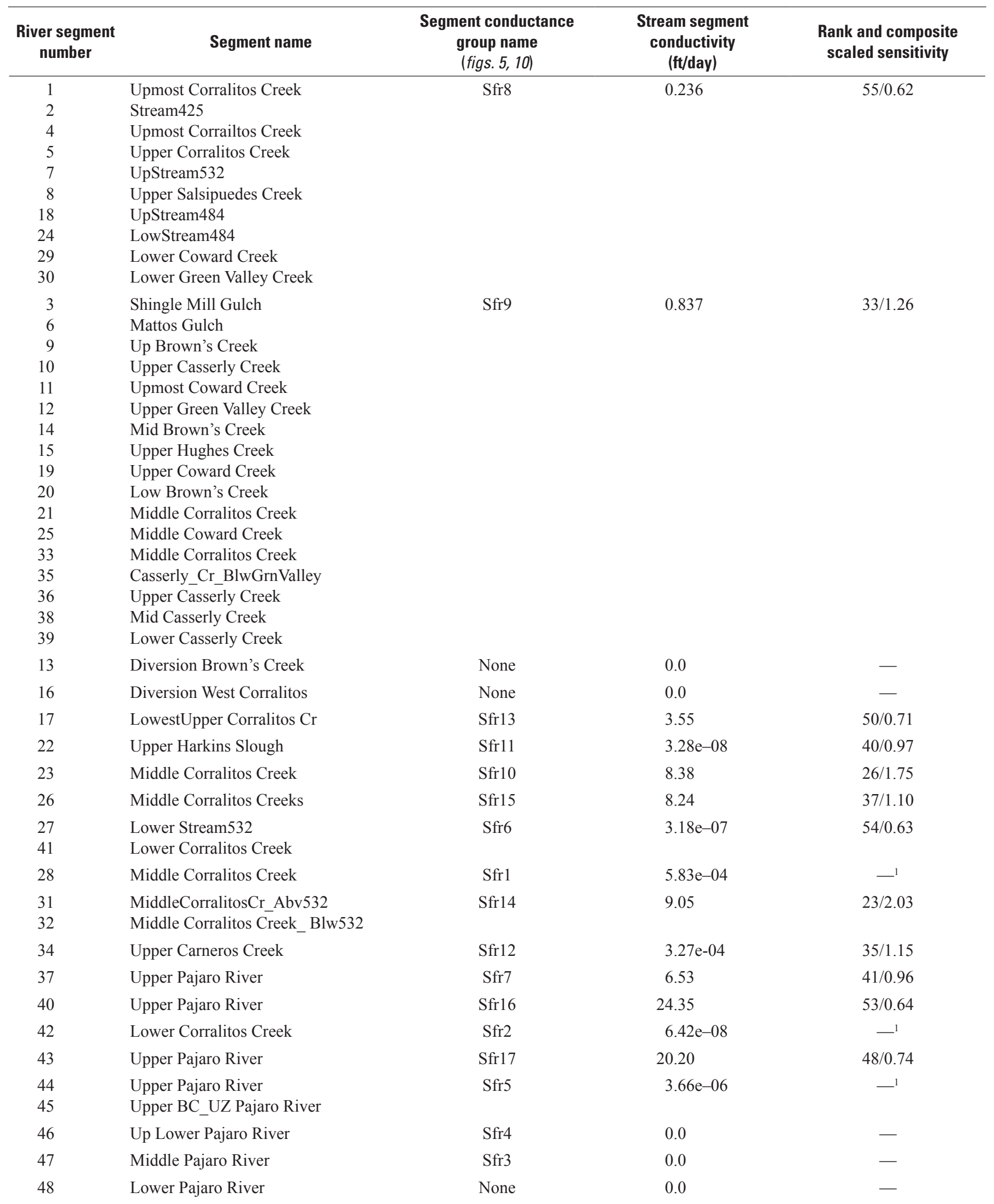


Table 14. Summary of streambed vertical hydraulic conductivity parameters and calibrated values, Pajaro Valley, California.Continued

$[-$, not estimated $]$

\begin{tabular}{clccc}
\hline $\begin{array}{c}\text { River segment } \\
\text { number }\end{array}$ & \multicolumn{1}{c}{ Segment name } & $\begin{array}{c}\text { Segment conductance } \\
\text { group name } \\
\text { (figs. 5, 10) }\end{array}$ & $\begin{array}{c}\text { Stream segment } \\
\text { conductivity } \\
\text { (ft/day) }\end{array}$ & $\begin{array}{c}\text { Rank and composite } \\
\text { scaled sensitivity }\end{array}$ \\
\hline 49 & Middle Carneros Creek & None & 0.0 & - \\
50 & Upper Watsonville Slough & None & 0.0 & - \\
51 & Lower Harkins Slough & Sfr11 & $3.28 \mathrm{e}-08$ & - \\
52 & Diversion Harkins Slough & None & 0.0 & - \\
53 & Lower Watsonville Slough & None & 0.0 & - \\
54 & Lower Carneros Creek & None & 0.0 & - \\
55 & Lowest Pajaro River & None & 0.0 & - \\
\hline
\end{tabular}

${ }^{1}$ More than 85 percent correlated with another parameter and removed from regression and sensitivity analysis.

Calibration started with the landscape processes, followed by adjustment of hydraulic properties, streambed properties, multi-aquifer well properties, general-head boundary conductances, and fault conductances. Since many of these properties are head dependent or correlated through their exchange of water, these properties were adjusted recursively through automated and trial-and-error analysis. The calibration process also required modifications to the parameter framework. For example, calibration required additional partitions of hydraulic property zones for the alluvium and upper Aromas aquifer layers, and alignment of the zones for the lower Aromas with the textural distribution. Only those parameters for which simulation results were sensitive to parameter values were adjusted during automated calibration.

\section{Farm Process Parameters}

Farm Process parameters that were adjusted during calibration included selected crop properties. These included scale factors for seasonal crop coefficients, fractions of total precipitation, runoff from inefficient losses from precipitation and irrigation for selected crops and natural vegetation, and seasonal scale factors for irrigation efficiencies. The scale factors for seasonal crop coefficients are analogous to stress factors that amplify or reduce the crop coefficients that were estimated under unstressed conditions. Because crop coefficients are estimated under unstressed conditions, they required small increases of 5 to 10 percent for dry-year seasons and reductions of 5 to 15 percent for wet-year seasons (table 13) to align estimated agricultural pumpage with reported pumpage (fig. 36C). The scale factors for $\mathrm{K}_{\mathrm{c}}$ values were adjusted manually to reach somewhat subjective matches to observations of ET and agricultural pumpage (table 13), which suggest that irrigation is less efficient during wetter periods. Runoff from selected crops and native vegetation is a direct control on the water available for deep percolation, discharge through tile drains, or as overland runoff back to the streamflow network. The PVHM required the interception of deep percolation in most of the coastal areas in the regions of tile-drained fields; conceptually, the lack of deep percolation in this area is consistent with the dampened or almost nonexistent variation from climatic variability in most waterlevel hydrographs in the floodplain regions of Pajaro Valley (figs. 30C-F). The fractions of inefficient losses to runoff were adjusted for truck and vegetable crops, orchards, field, pasture, and grain-and-hay crops. Similarly, fractions of runoff from precipitation were increased to control the deep percolation and additional runoff from the native vegetation that grows principally in the foothills of the headlands along the flanks of the Santa Cruz Mountains, which is the largest component of the land use in Pajaro Valley.

\section{Hydraulic Parameters}

The model itself was used to determine the values of 12 hydraulic properties during calibration. The values of $K_{c}$ (coarse-grained) and $K_{f}$ (fine-grained) for each model layer were adjusted to produce simulated heads representing the long-term trends in the aquifer and to produce heads that best matched the measured heads and estimated streamflow losses. Because of the differences in depositional environments within the various zones of each layer, the hydraulic properties were also adjusted subregionally with 55 multipliers for horizontal and vertical hydraulic conductivity and storage properties (fig. 27). Other properties that were adjusted manually include porosities, specific yields, skeletal specific storage for coarseand fine-grained end-members, and the exponent (p) used to calculate the vertical hydraulic conductivity. Values of $p$ for each model layer were adjusted, resulting in values of vertical hydraulic conductivity that are close to the harmonic mean of vertical hydraulic conductivity $\left(\mathrm{K}_{\mathrm{v}}\right.$; equations 2 and 4 ) for the aquifer layers and closer to the geometric mean of $\mathrm{K}_{\mathrm{v}}$ for the confining layers. The compressibility of water was specified as a component of the storage properties proportional to the coarse- and fine-grained porosities and was not adjusted. 
The calibration of hydraulic properties involved the adjustment and rescaling of these intrinsic properties based on water-level hydrographs and water-level maps. The most sensitive hydraulic property parameter was the coarse-grained hydraulic conductivity ( $\left.\mathrm{K}_{c}\right)$ of the alluvium (fig. 38) that, in part, controlled the seasonal amplitudes and associated vertical water-level differences between aquifer layers. Scaled reductions of the magnitude of $\mathrm{K}_{\mathrm{v}}$ within selected confined zones and scaled increases within unconfined zones of vertical hydraulic conductivity and storage properties were required. Horizontal hydraulic conductivities required increases in many of the aquifer layers in the confined coastal zones (table 13). Because the model was less sensitive to values of porosity and specific yield, these were not included in automated parameter estimation.

\section{Streamflow Properties}

Streambed vertical hydraulic conductivity parameters also were calibrated. Groups of stream segments in which channel conditions were similar were represented by 17 parameters of streambed vertical hydraulic conductivity (figs. 5, 10; table 14). All streams were simulated with variable stage-width-discharge relations. The initial estimates of streamflow conductivity values and the stage-discharge relations were derived from the previous PVIGSM model (Teghavi and Smith, 1999f) and modified during the redesign of the network and subsequent model calibration. Streamflow stage-width-discharge relations were not calibrated and were maintained at values similar to those in the previous PVIGSM model. The groupings and calibrated streambed vertical hydraulic conductivity values range from zero near the coast to about $24 \mathrm{ft}$ /day upstream from Murphy's Crossing on the Pajaro River (table 14). Monthly streamflows and diversions, as well as streamflow losses between gages, were used to help estimate streambed vertical hydraulic conductivities.

\section{Multi-Aquifer Well Parameters}

The skin factors in the MNW package affected the interlayer flow and related water-level differences between model layers. Six skin factors were used as parameters to control the retardation of wellbore flow within specific layers for the multi-aquifer wells (table 13). These included individual skin factors for each model layer. Skin factors were relatively high to maintain the observed head differences and control wellbore flow between layers. The final calibrated skin factors ranged from 32 for the upper Aromas layer to 68 for the Purisima Formation, layer 6 (table 13).

\section{General-Head Boundary Parameters}

The conductance factors in the general head boundary (GHB) package affected the offshore as well as the northern and southern onshore boundary flows. In turn, these flows affected water levels and the coastal inflow and outflow that were a surrogate for seawater intrusion. Individual parameters were used to control the retardation of boundary flows within specific subregions for each of the four aquifer layers (table 13). A total of 40 scale factors (table 13) were used to control hydraulic conductances within specific subregions of boundary cells or offshore outcrop regions ( $f$ ig. $9 A$ ). The final conductance values that controlled onshore underflow from the northern and southern boundaries have a wide range between 1,110 and $2 \times 10^{-4} \mathrm{ft}^{2} / \mathrm{d}$. The water levels in the upper and lower Aromas along the southern boundary were the most sensitive to changes in onshore GHB conductances. Offshore conductances represented both vertical (GHB boundary cell group 1) and horizontal flows (groups 2, 4, 6, and 7; fig. 9A). The offshore vertical flow conductances were set to $328 \mathrm{ft}^{2} / \mathrm{d}$ in the offshore outcrops of the upper Aromas and Purisima Formations (table 13). The offshore horizontal conductances ranged from $328 \mathrm{ft}^{2} / \mathrm{d}$ for the near-shore alluvium to between 0.3 and $3 \times 10^{-5} \mathrm{ft}^{2} / \mathrm{d}$ for offshore boundaries in all aquifer layers (table 13).

\section{Horizontal Flow Barrier Parameters}

The conductance factors in the horizontal flow barrier (HFB) package affected the subsurface flow of water between the recharge areas in the inland areas where the Purisima Formation crops out and the coastal regions. In turn, these flows affected not only water levels but also indirectly affected the coastal inflow and outflow that was a surrogate for seawater intrusion. One parameter was used for the entire extent of the Zayante Fault within the lowest aquifer layer representing the upper part of the Purisima Formation (table 13). 


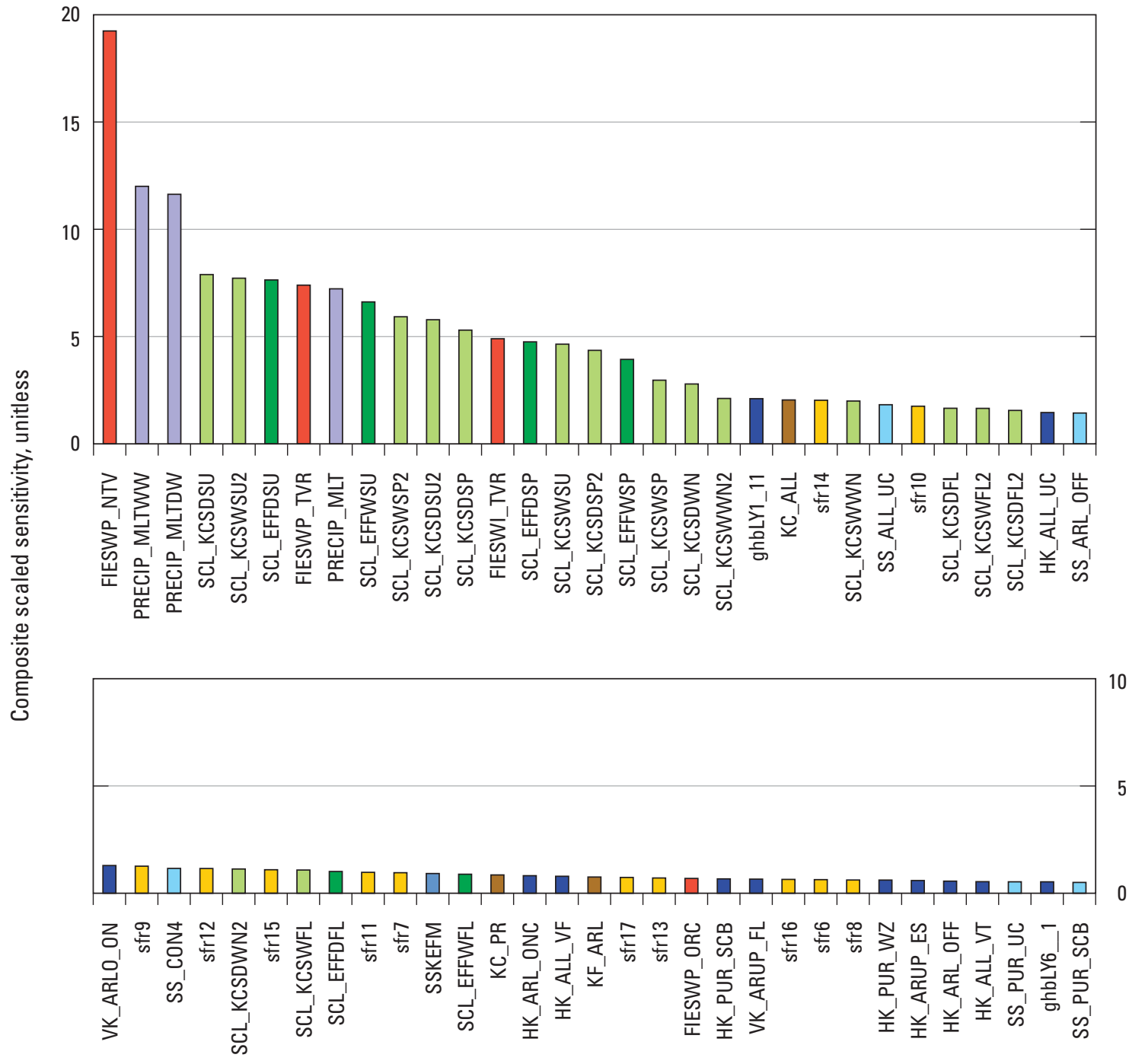

Parameter identifier

\section{EXPLANATION}

Parameter groups-

Farm Process
$\square$ Runoff
$\square$ Precipitation
$\square$ Kc properties
$\square$ Irrigation

$\square$ Storage property
$\square$ Storage property multiplier
$\square$ Streambed conductivity
$\square$ Hydraulic conductivity
Hydraulic conductivity multipliers

See tables 13 and 14 for names and explanations of all parameter identifiers.

Figure 38. Relative composite sensitivity of computed heads, flows, and pumpage information at calibration points to changes in parameters. Composite scaled sensitivity values are used here to show relative sensitivity; the definition and derivation are described in Hill and others (2000). 


\section{Sensitivity Analysis}

The suite of observations used to analyze PVHM simulations were sensitive to changes in selected model parameters representing landscape properties, and to a lesser extent to selected scale factors for hydraulic properties for the aquifers, streambed vertical hydraulic conductivities, horizontal hydraulic conductivities, and the GHB conductance scale factors for onshore boundaries and offshore outcrop areas. The model periodically had convergence problems when some of the parameters were perturbed out of the range of the final set of specified values, or when the model required a conceptual change to its structure or parameter distribution. Thus the application of systematic parameter-estimation techniques to estimate selected model parameters and related sensitivities that are based on perturbation approaches was limited to providing guidance for sensitivity analysis rather than a comprehensive assessment.

The sensitivity process in UCODE identifies the sensitivity of computed values at the locations of measurements to changes in model parameters. It was used to identify which parameters to include in the Parameter Estimation Process (Hill and others, 2000) and to adjust during calibration. Results of the Sensitivity Process indicate that the model was most sensitive to changes in the parameters related to scale factors of the partitioning of precipitation, stress coefficients for crop coefficients, climate-based scale factors (eight wet and dry seasons) for the inefficient runoff from precipitation and irrigation and irrigation efficiency (table 13). These parameters are shown in declining order of sensitivity in figure 38. The model output is most sensitive to the fraction of precipitation that becomes runoff over native vegetation. This sensitivity, and the large fraction of runoff that represents primarily winter and spring precipitation, is partly an artifact of the monthly discretization of precipitation, which does not completely account for rainfall duration and intensity, slope of hillsides, variation in native vegetation, and most rainfall occurring in the forested foothills of the Santa Cruz Mountains. This parameter controls a major contribution to recharge from deep percolation as well as ungaged runoff contributions to streamflow. The next most sensitive parameters were the scale factors for wet and drywinter precipitation, which were set to the units conversion value and were unchanged; thus, all precipitation is included in the model for all seasons and this set of parameters was not used in final model calibration. Observations of the flow of Corralitos Creek at Freedom were most sensitive to these first three runoff and precipitation parameters. The remainder of the 20 most sensitive parameters were mostly spring and summer scale factors for crop coefficients and irrigation efficiencies. These parameters were most sensitive to observations of pumpage, water levels, and streamflow on the Corralitos Creek at Freedom The most sensitive parameter that partly controls simulation of seawater intrusion was the general-head boundary conductance for lateral coastal flow within the alluvial layer (ghbLY1_11 is parameter no. 21, fig. 38). The GHB conductance scale-factor parameter was most sensitive to pumpage observations from 2005. The most sensitive streamflow parameters were related to sections of Corralitos Creek (sfr14, sfr10), Upper Carneros Creek (sfr12), selected tributaries (sfr9), and the uppermost reaches of the Pajaro River (sfr7).

\section{Hydrologic Flow Analysis}

The inflows and outflows of the revised conceptual model (fig. 2A) have been incorporated into the PVHM simulation of the conjunctive use and movement of water in Pajaro Valley. The major inflows and outflows to the groundwater flow system within the hydrologic cycle for the PVHM and the previous PVIGSM indicate some similarities and several differences (fig. 39). Overall, the storage depletion and net coastal inflow that represents seawater intrusion still depict a condition of overdraft. The PVHM confirms that these conditions have continued to persist since the end of the simulation of the previous PVIGSM in 1997 up through 2009. The PVHM indicates a level of pumpage that is consistent with recent years of reported pumpage. The PVHM also indicates slightly less average annual streamflow infiltration and storage depletion than does the PVIGSM, and slightly more outflow to the Monterey Bay as well as a significant component of agricultural discharge through tile-drain fields. Two of the differences in concept and simulation between the current model (PVHM) and the previous model (PVIGSM) are the additional coastal inflow along the northern and southern boundaries with a comparable decrease in direct infiltration and the inclusion of the agricultural tile-drain field discharge. The net result is still an average annual overdraft of about 12,510 acre-ft per year (fig. 39). As with the previous PVIGSM, the overdraft in the current model reflects predominantly cycles of storage depletion in the inland regions and coastal inflow (specifically, seawater intrusion) in the coastal regions that is climatically driven over seasonal to interdecadal periods, but also shows contributions from tiledrain discharge in the floodplain regions of the Pajaro River. 


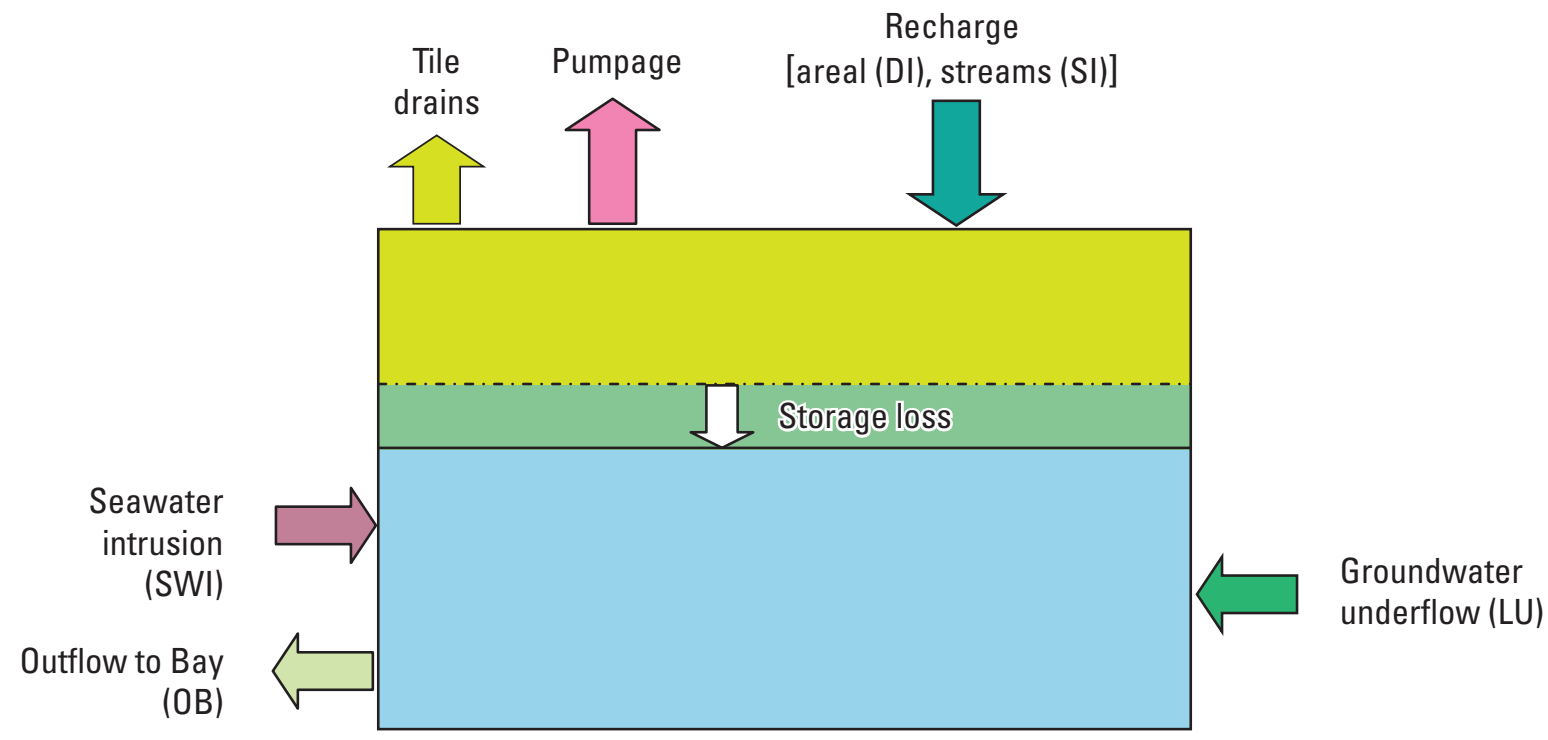

\section{GROUNDWATER-BUDGET SUMMARY}

\begin{tabular}{|c|c|c|c|}
\hline Source & BMP (PVIGSM) ${ }^{1}$ & PVHM & PVHM \\
\hline Period (Water years) & 1964-1997 & 1964-1997 & 1964-2009 \\
\hline \multicolumn{4}{|l|}{ Inflows, in acre-feet per year: } \\
\hline Landward underflow (LU) & 3,000 & 3,430 & 3,460 \\
\hline Direct infiltration (DI) & 39,000 & 29,910 & 30,770 \\
\hline Streamflow infiltration (SI) & 17,000 & 14,130 & 14,470 \\
\hline Total recharge (DI+SI): & 56,000 & 44,040 & 45,240 \\
\hline Total onshore inflows: & 59,000 & 47,470 & 48,700 \\
\hline \multicolumn{4}{|l|}{ Outflows, in acre-feet per year: } \\
\hline Storage/flow depletion: & 3,000 & 0 & 100 \\
\hline Storage depletion masked by SWI & 7,000 & 4,060 & 3,210 \\
\hline Outflow to Bay (OB) & 0 & 820 & 720 \\
\hline Tile drains & NS & 4,710 & 4,880 \\
\hline Pumpage: & 69,000 & 52,170 & 52,740 \\
\hline Total onshore outflows: & 79,000 & 61,760 & 61,650 \\
\hline Inflows - Outflows $=$ & $-20,000$ & $-14,290$ & $-12,950$ \\
\hline
\end{tabular}

1Raines, Melton, and Carella, 1999, figure 3-2.

Figure 39. Simulated average flow of groundwater through the hydrologic cycle, Pajaro Valley, California. [BMP, Basin Management Plan; NS, not simulated; PVHM, Pajaro Valley Hydrologic Model; PVIGSM, Parajo Valley integrated groundwater-surface water model] 
The temporal distribution of inflows and outflows indicate a strong climatic influence (fig. 40A). More inflows and outflows occur during the wetter years, during which both wellbore flow and agricultural pumpage are reduced. Water is also entering and leaving storage in different parts of the model at the same time. The wellbore flow, though limited to just a few multi-aquifer wells, also is a significant component of the revised conceptual model. The temporal distribution of net flows shows the increase in storage depletion (inflow of water from net storage, fig. 40B), coastal flow, and streamflow infiltration with a reduction of areal recharge, tile-drain return flows, and net wellbore flow during dry periods (fig. 40B). Climate-driven changes of inland underflow from the SoquelAptos area to the north and the Salinas Valley to the south are less pronounced owing to the regionally low groundwater levels that now persist during wet and dry periods since the drought of the mid-1980s and early 1990s. Some storage replenishment does occur during wet years that offset some of the storage depletion in dry years (fig. 40B). The flows into (recharge) and out of (discharge) the groundwater flow system range from about 40,000 acre-ft per year during dry periods to more than 80,000 acre-ft per year during selected wet periods.

The temporal distribution of groundwater pumpage is dominated by pumpage for agricultural uses. Rural residential pumpage is a small but steady component of total pumpage, and municipal pumpage has also been relatively constant (fig. 41A). Again, the amount of agricultural pumpage varies with the wet and dry climate periods, with increases of more than ten percent during sustained dry periods. The relative reductions in pumpage during the intervening wet periods also indicate that the amount of water used for agriculture and related irrigation is still quite sensitive to climatic conditions - applications for irrigation are supplemented by precipitation, a portion of which is consumptively used by crops. About 50 to 60 percent of groundwater pumpage was simulated to be withdrawn from the upper Aromas (fig. 41B). The alluvium (10 to 25 percent) and to a lesser extent the Purisima (10 to 20 percent) are significant sources of water, whereas only about 10 percent of total pumpage is simulated to come from the Lower Aromas. The total pumpage ranges from less than 40,000 acre-ft per year during selected wet years to more than 70,000 acre-ft per year during selected dry years (figs. 41A, B). As with the previous PVIGSM, the distribution of pumpage indicates that about 65 percent of the rural residential pumpage, most of the municipal pumpage, and 61 percent of the agricultural pumpage occurs in the inland regions.

The temporal distribution of inflows and outflows across the landscape indicate that inflows and outflows from precipitation play a significant role in the hydrologic cycle (fig. 42A). Evapotranspiration from groundwater is a minor component of inflow to the landscape, and runoff, predominantly from precipitation, is a major outflow from the landscape. Deep percolation from precipitation and irrigation persists for all years but is generally larger during wet years. The relative proportions of water as inflows and outflows to the landscape also demonstrate the importance of precipitation (79 percent) and runoff (35 percent; fig. 42B). The landscape flows are the most sensitive to climatic variability, and range from less than 150,000 acre-ft during selected dry years to more than 300,000 acre-ft during selected wet years (fig. 42A).

More than 80 percent of the recharge occurs within the Alluvial aquifer system layer (fig. 43), owing to the distribution of outcrops (fig. 3A) and confining layers (fig. 25). Significant portions of recharge also occur, however, within the outcrop areas of the Purisima Formation (10 percent) and the upper Aromas (7 percent). As with pumpage and runoff, the deep percolation below the root zone that constitutes recharge to the groundwater flow system is driven by the climate variations. Simulated recharge during wet periods can be more than double the recharge from adjacent dry periods (figs. 40B, 42A). This recharge, along with pumpage, drives the downward migration of recharge through wellbores and across geologic layer boundaries. The flow from the alluvial deposits (layer 1) to the upper Aromas aquifer (layer 3) varies with climate but is predominantly downwards towards this layer, from which most of the pumpage occurs (fig. 43B). Flow within the Lower Aromas aquifer is downward to the upper Purisima during most years but can be upward to the Lower Aromas layer during some wet years.

The overall net recharge ranges from less than 30,000 acre-ft per year during most dry years to more than 40,000 acre-ft per year for many wet years $(f i g .40 B)$. The median distribution of net recharge is largely coincident with the alluvial channels of the streamflow network, the regions of tile drains, and the inland and coastal regions representing outcrops of the Aromas (fig. 43C). Areally distributed recharge is higher in the northern part of the study area, where precipitation is larger than in the south, and in the regions of tile drains where irrigation is more intensive. The areas of large negative net recharge are those regions with ET greater than deep percolation. These regions are also generally coincident with the regions in Santa Cruz County that were identified as primary groundwater recharge areas (Santa Cruz County, 2009) and with the regions identified by Hecht (J.H. Kleinfelder and Assoc., 1983). As with the previous PVIGSM, about 72 percent of the direct infiltration recharge from precipitation and irrigation and about 97 percent of the streamflow infiltration occurs in the inland regions. Much of the intensive artificial recharge related to irrigation in the central valley region is intercepted by the tile drains and becomes engineered runoff (fig. $43 \mathrm{C}$ ). 


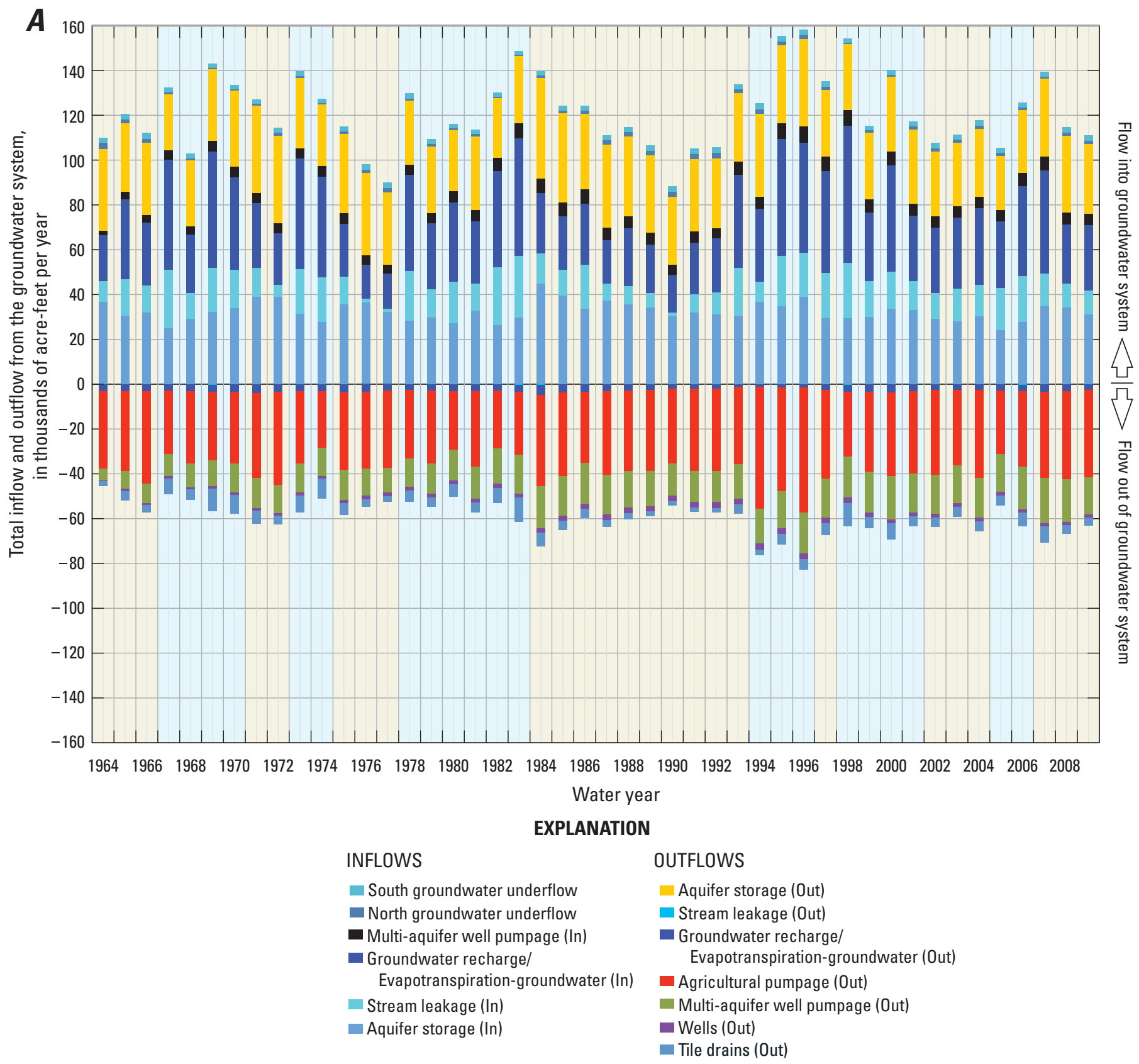

Recent precipitation cycles

Dry

Wet

Figure 40. Temporal distribution of $A$, total inflows and outflows; and $B$, total net inflows and outflows to the simulated groundwater flow system within the Pajaro Valley hydrologic model (PVHM), Pajaro Valley, California. 


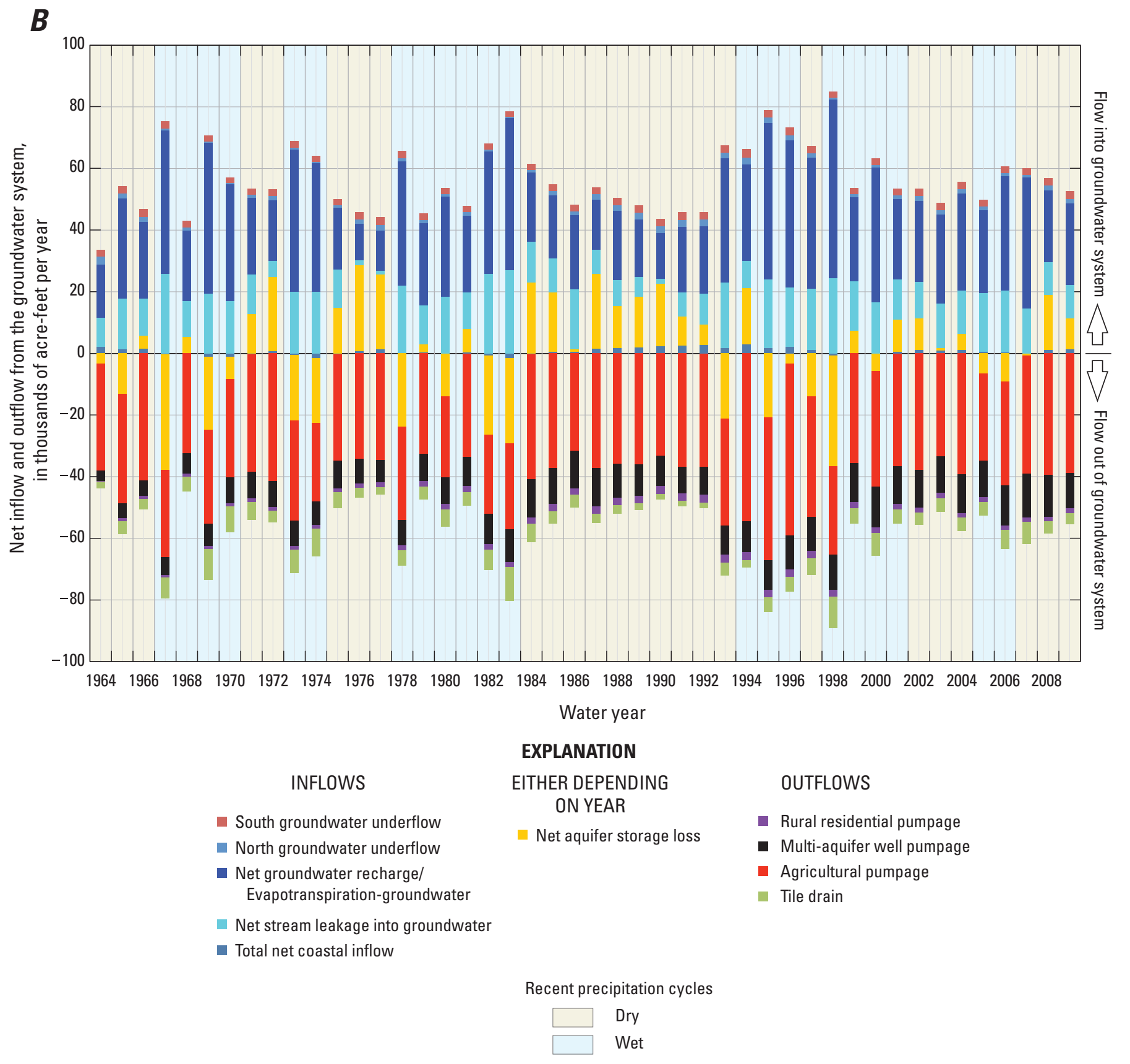

Figure 40. -Continued 


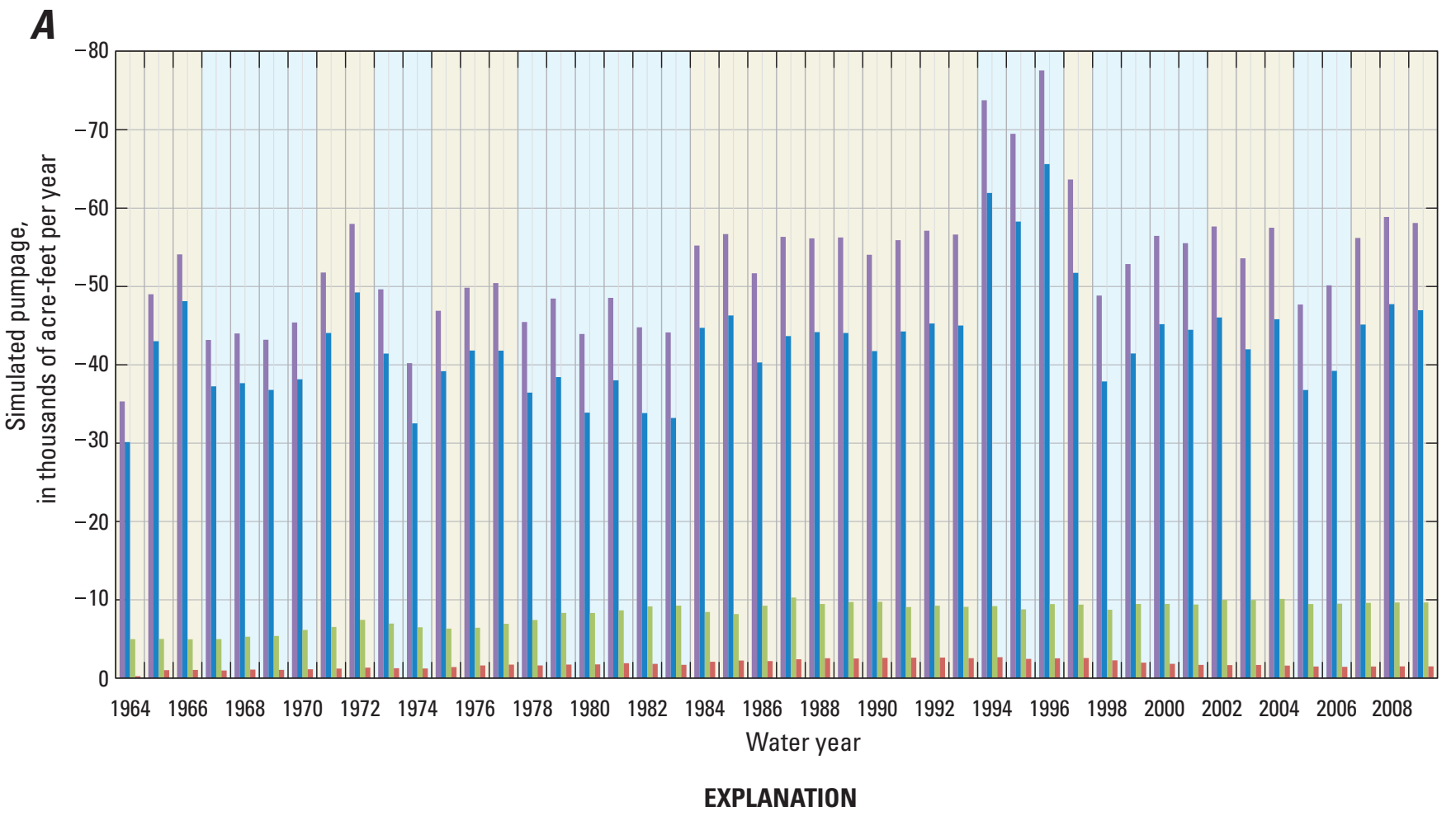

Simulated pumpage within Pajaro Valley hydrologic model, Pajaro Valley, California

- Total pumpage

- Agricultural

- Public supply

- Rural residential

Recent precipitation cycles

$\square$ Dry

Wet

Figure 41. Simulated groundwater pumpage for the water years 1964-2006, for $A$, total for all model layers; and $B$, net for aquifer layers, Pajaro Valley, California. 


\section{$\boldsymbol{B}$}

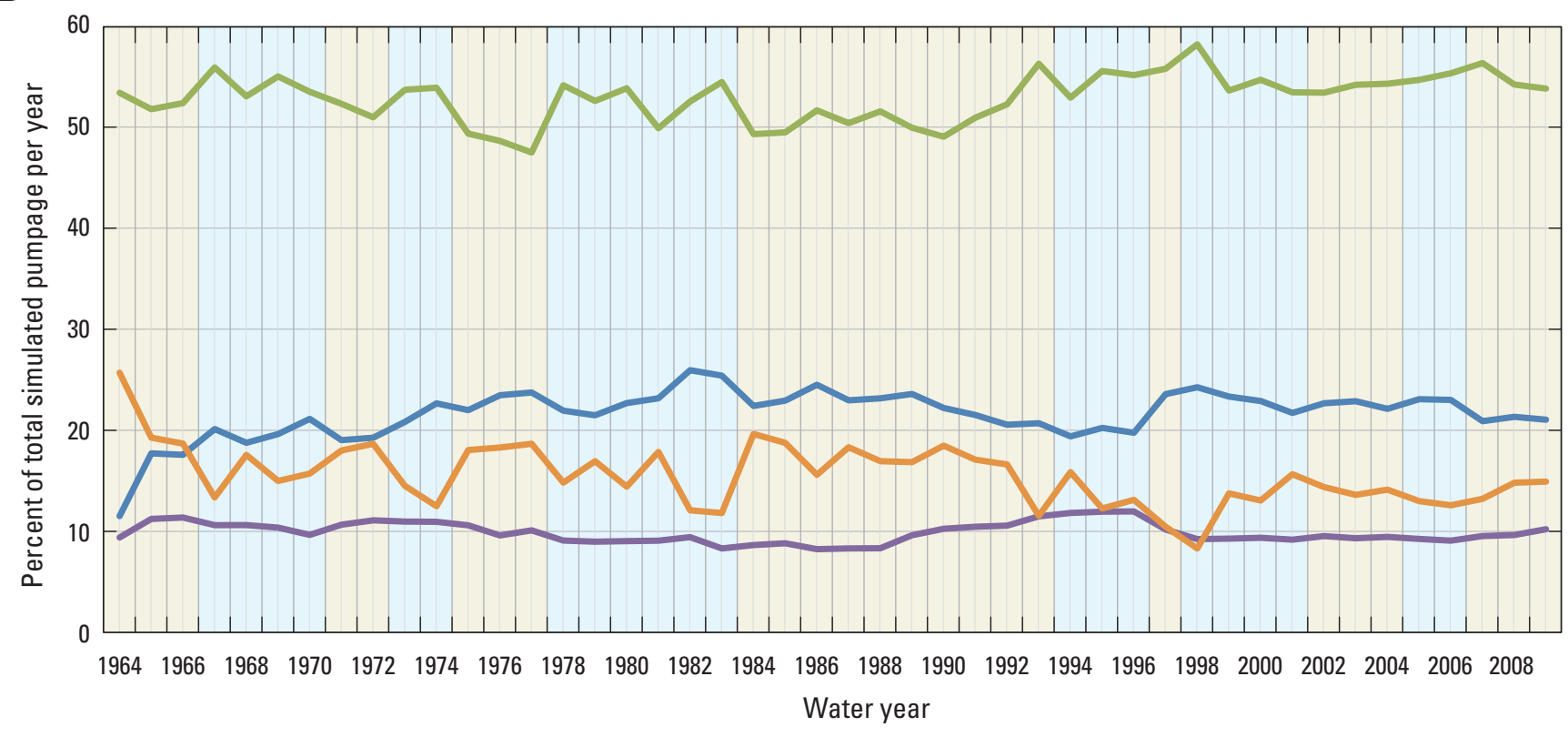

EXPLANATION

Percent total pumpage by layers for Pajaro Valley, California

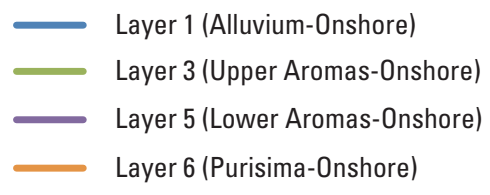

Recent precipitation cycles

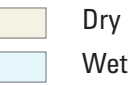

Figure 41. - Continued 


\section{$\boldsymbol{A}$}

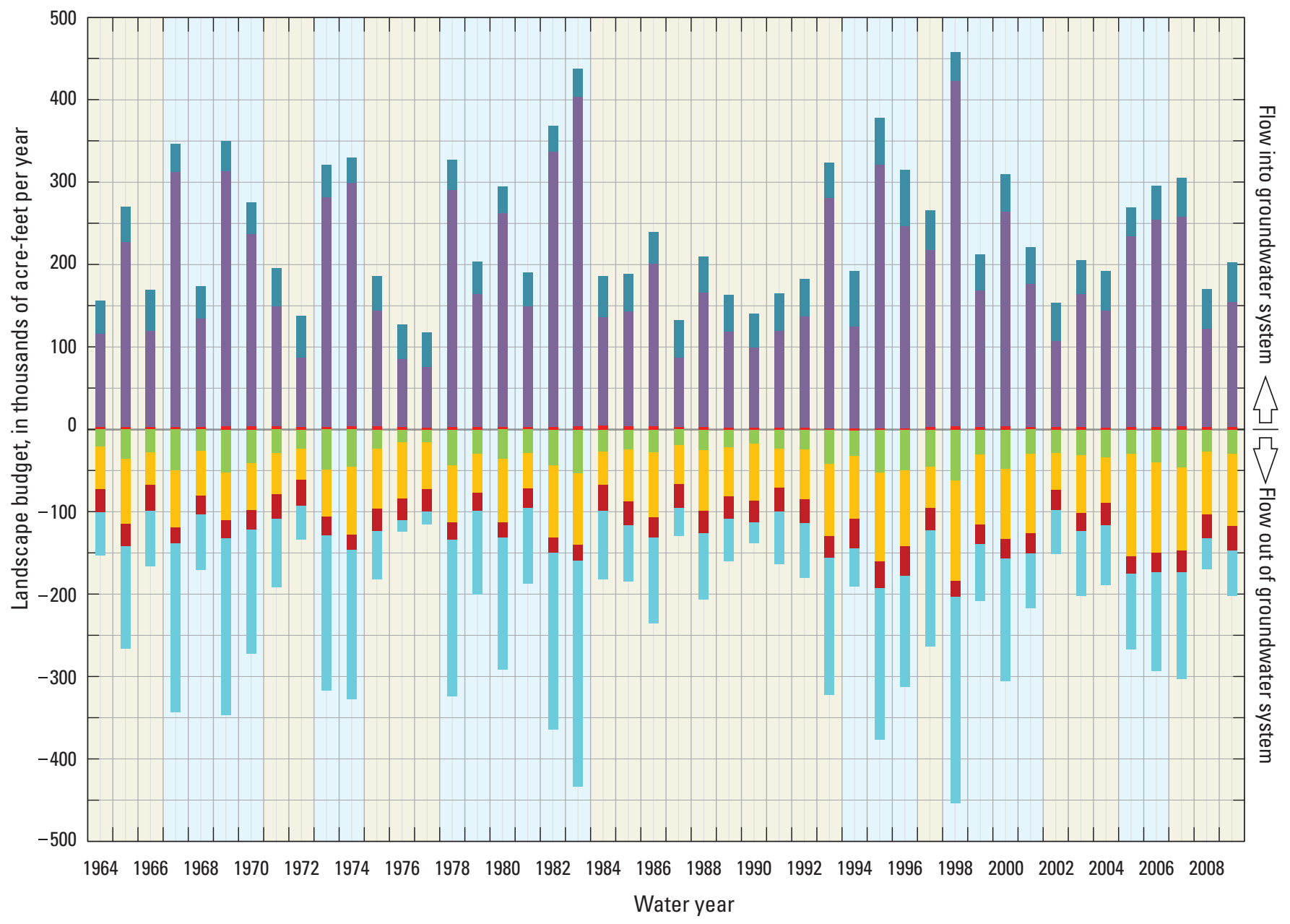

EXPLANATION

Landscape budget through time for Pajaro Valley, California

$$
\begin{aligned}
& \text { - Pumpage } \\
& \text { - Evecipitation } \\
& \text { - Deep percolation } \\
& \text { - Evapotranspiration from precipitation } \\
& \text { - Evapotranspiration from irrigation } \\
& \text { Runoff }
\end{aligned}
$$

Recent precipitation cycles

Dry

Wet

Figure 42. A, Temporal distribution of total inflows and outflows; and $B$, Average annual components of farm budget of the simulated landscape flow system within the PVHM hydrologic model, Pajaro Valley, California. 


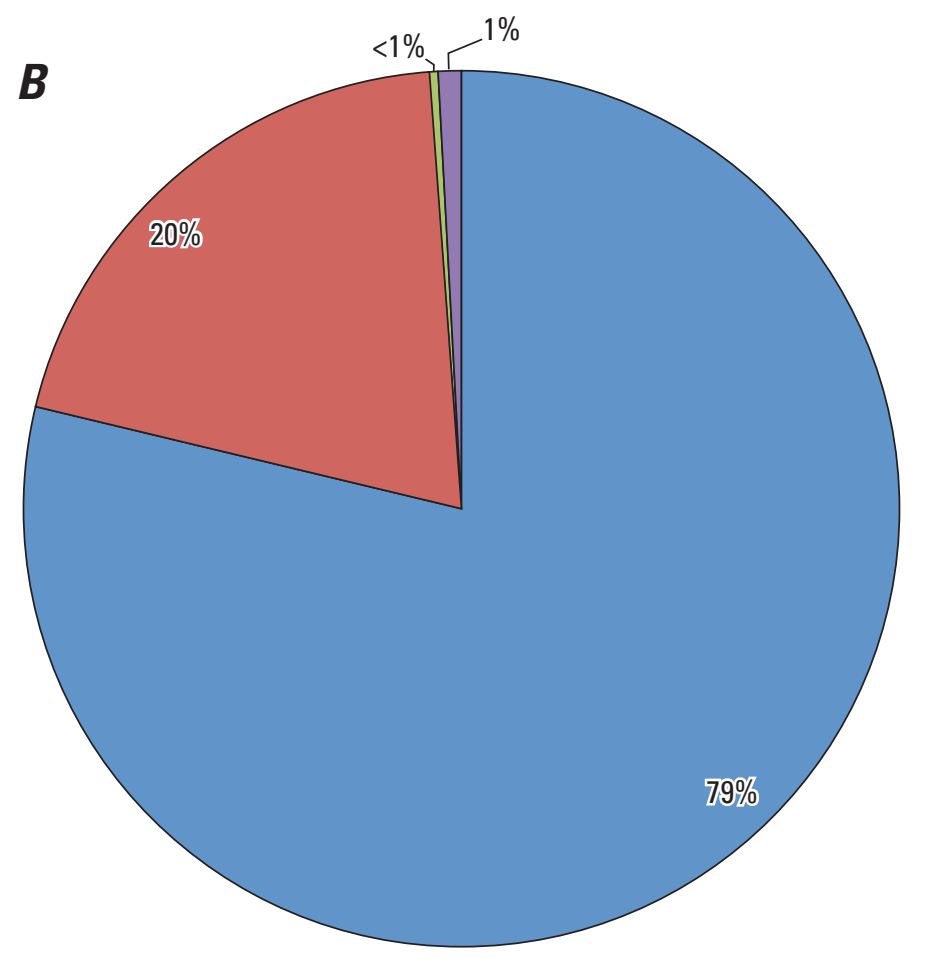

Average landscape inflows

- Precipitation

- Groundwater well pumping deliveries

- Evaporation uptake directly from groundwater

Transpiration uptake directly from groundwater

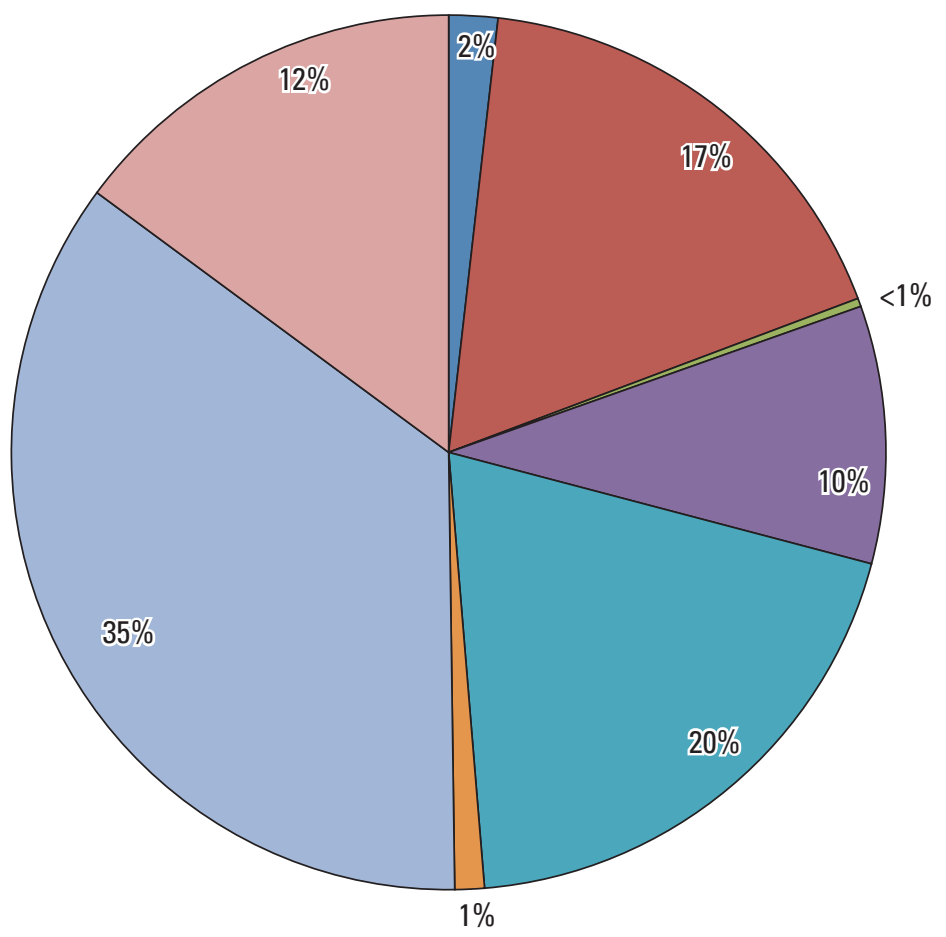

Average landscape outflows

Evaporation from irrigation

Evaporation from precipitation

Evaporation from groundwater

Transpiration from irrigation

Transpiration from precipitation

Transpiration from groundwater

Overland runoff

Deep percolation

Figure 42. - Continued 


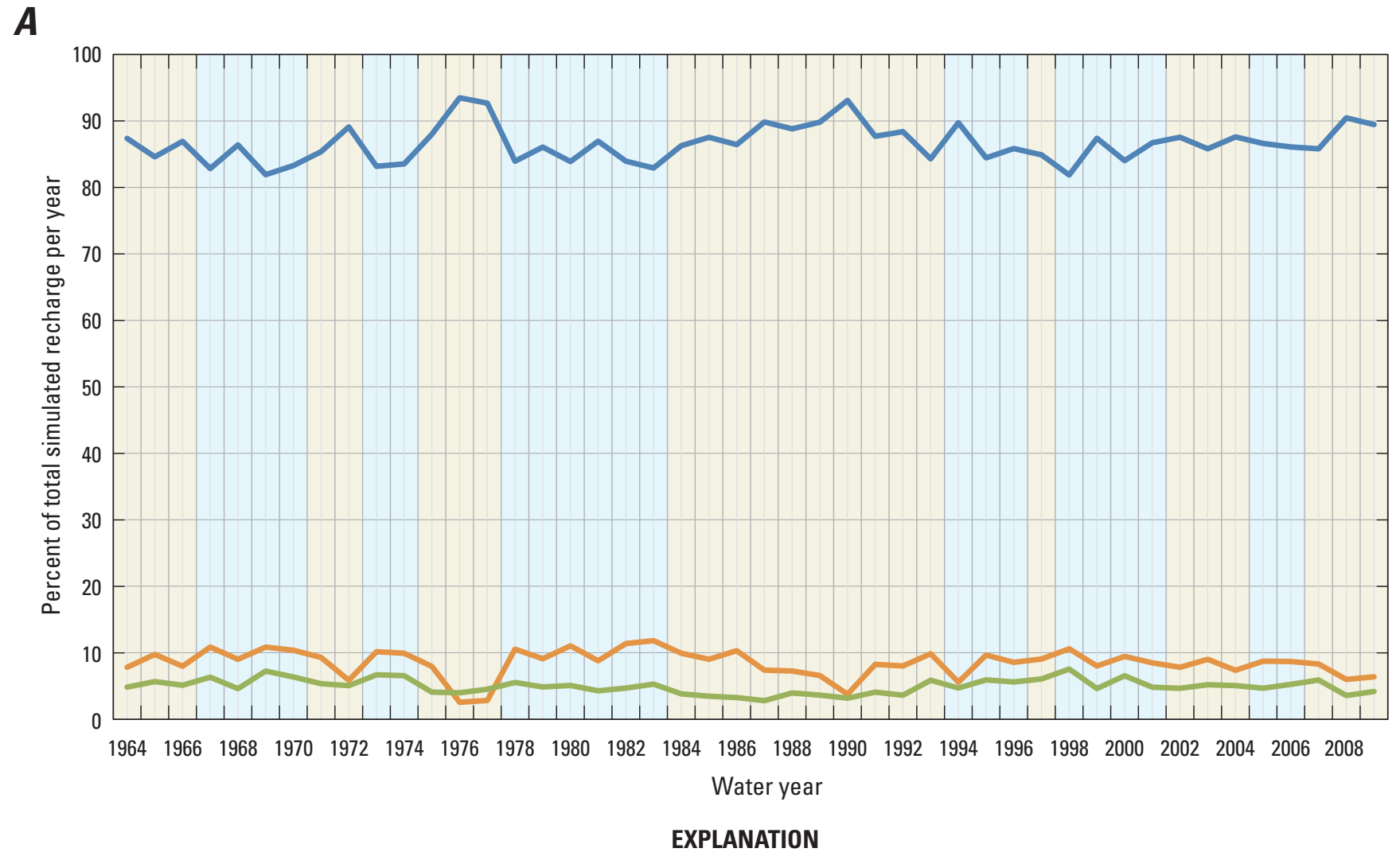

Percent total recharge by layers for Pajaro Valley, California

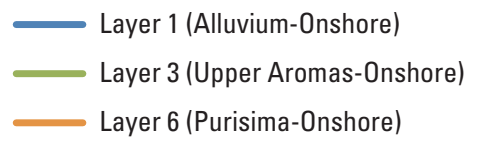

Recent precipitation cycles

Dry

Wet

Figure 43. $A$, Total recharge by aquifer model layers; $B$, net downward flow between upper aquifer model layers; and $C$, distribution of median farm net recharge, Pajaro Valley, California. 


\section{B}

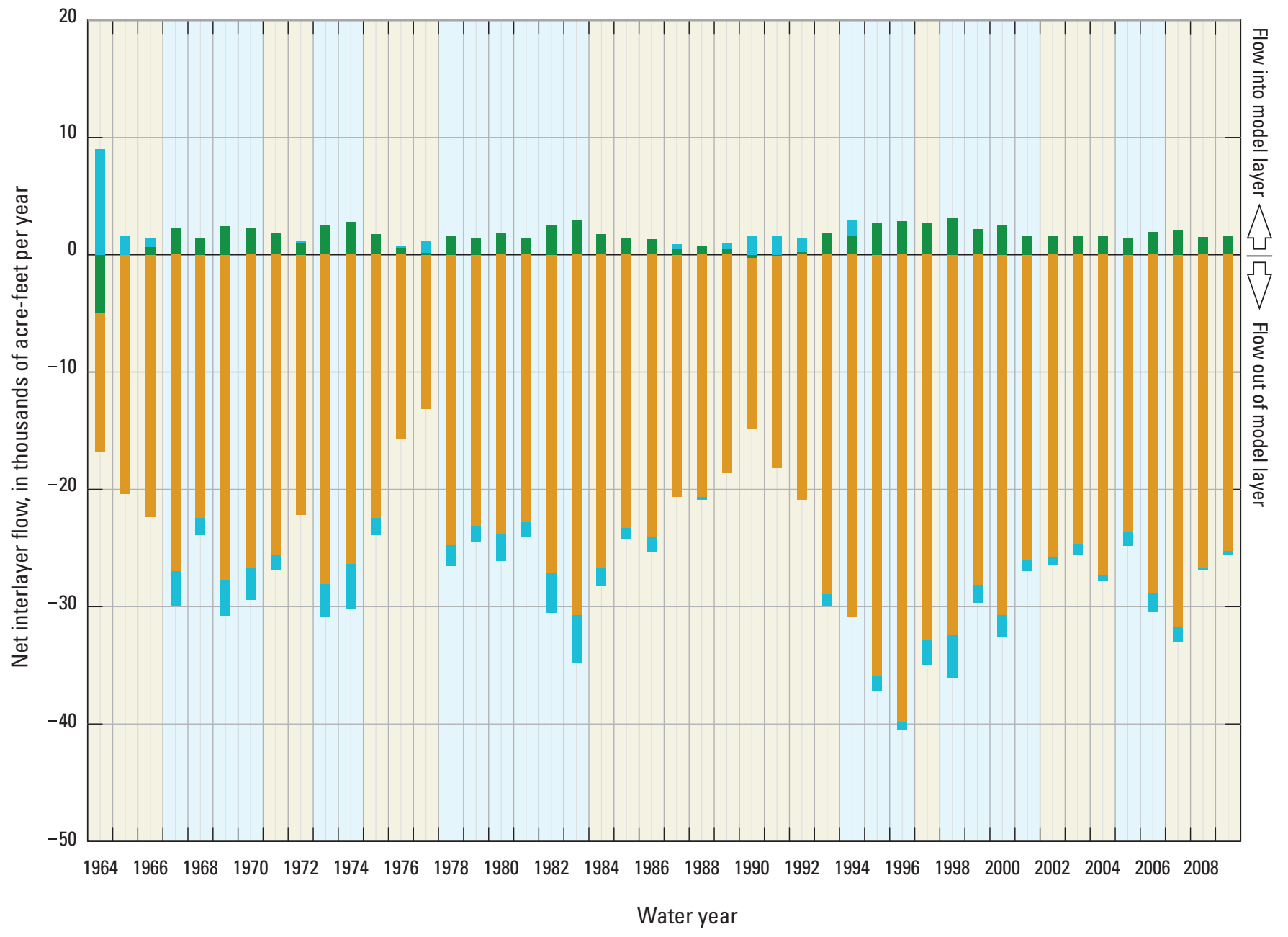

EXPLANATION

Net interlayer flow of groundwater

for onshore portions of model layers

- To LY1 from LY2 and LY3

- To LY3 from LY4 and LY5

- To LY5 from LY6

Recent precipitation cycles

\begin{tabular}{|l|l}
$\square$ \\
$\square$
\end{tabular}

Wet

Figure 43. - Continued 


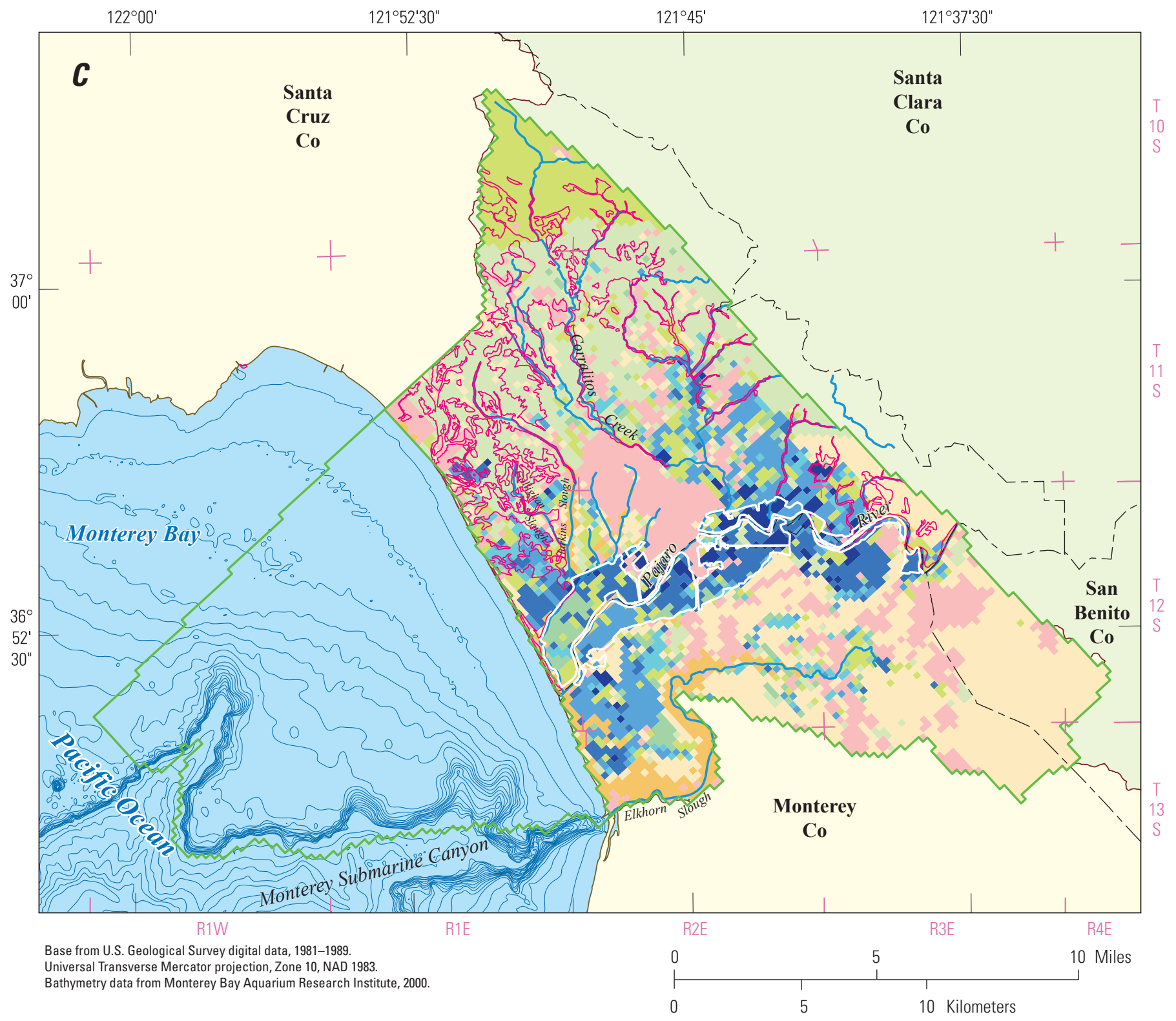

\section{EXPLANATION}

\begin{tabular}{|l}
\hline Pajaro River watershed \\
$\begin{array}{l}\text { Outside Pajaro River } \\
\text { watershed }\end{array}$ \\
$\begin{array}{l}\text { Reported tile drain areas (PVWMA, } \\
\text { written commun., September, 2012) }\end{array}$ \\
Model grid boundary \\
River or streams \\
Bathymetry \\
contours
\end{tabular}

$\square$ Santa Cruz County primary areas for potential groundwater recharge (from Santa Cruz County (2009))

Median value of Farm-net recharge per model cell, in acre-feet per year (Negative values indicate more evapotranspiration than recharge)

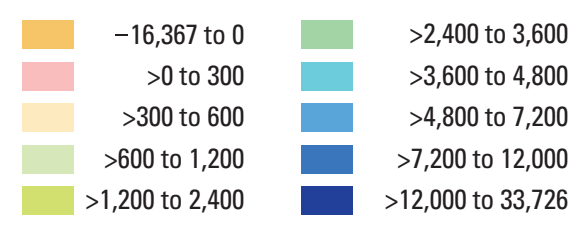

$>$ is greater than

Figure 43. - Continued 
The inflows and outflows from the landscape and streamflow networks to the groundwater flow system, combined with the sustained and climatically driven pumpage, result in sustained storage depletion and coastal inflows that result in the overdraft conditions that have plagued Pajaro Valley for decades (Johnson, 1982; Mann, 1988; Teghavi and Smith,1999g; Lear, 2001). The temporal distribution of net changes in groundwater storage indicate that most of the storage depletion has occurred in the Alluvial aquifer model layer, with significant amounts of storage depletion also occurring in the upper Aromas and Purisima Formation model layers (fig. 44A). Net changes in groundwater storage are also aligned with the climate periods; the average storage depletion is about 8,900 acre-ft per year during the 25 dry years, and the average storage replenishment is about 10,700 acre-ft per year during the 21 wet years (fig. 44A). Combined with storage depletion are significant amounts of coastal inflow (fig. 44B) that represent seawater intrusion; collectively, these represent the majority of the unsustainable overdraft. The majority of the coastal flow enters the landward parts of the aquifer system through the alluvium, with significant amounts also derived from inflow from the offshore outcrops of the upper Aromas (fig. 44B). The total simulated net coastal inflows during wet and dry years can range from less than 1,000 acre-ft per year to more than 6,000 acre-ft per year (fig. 44B). Some of the coastal flow shows a simulated reversal to coastal outflow in the Aromas and Purisima during selected wet years for outcrops along the northern shore of the Pajaro Valley but still showing a net reduced inflow in the Alluvial aquifer (figs. $3 A, 44 B$ ).

Analysis of potential simulated groundwater overdraft includes the analysis of storage depletion and coastal inflow. Although overdraft could also include capture of discharge from groundwater outflow or increased streamflow infiltration, the analysis here will be limited to these two major components.

On the basis of the average overdraft rate (Inflows minus Outflows, fig. 39) of about 12,950 acre-ft/yr, the simulated net overdraft over the complete model period (1964-2009) is about 575,000 acre-ft. The simulated overdraft is equivalent to about 11 years of pumpage based on the average during the modeled period, and about 4 years of pumpage based on the average rate of the last 5 years (2005-09). The majority of the storage depletion is simulated to occur in the inland subregions and the majority of the seawater intrusion occurs in the coastal subregions. While some replenishment occurs during wet years, the model and measured hydrographs and water-level maps generally indicate that the basin remains in a continued state of overdraft with sustained seawater intrusion that is subject to seasonal fluctuations every year and longterm increases during dry-year periods. The amount of water provided by the CDS that replaced some coastal pumpage was too small to enable detection of significant changes in coastal flows or groundwater levels during the last years of the simulation (2002-09). The net loss of usable aquifer storage could be considerably greater than indicated in this budgeting, however, because the mixing of seawater with ambient groundwater can render the latter unusable owing to even small fractions of seawater. Moreover, the salinity tolerance for many vegetable and fruit crops is relatively low. For the recent period 1999-2009, the average amount of tile-drain flow of about 4,900 acre-ft/yr, plus the average March to November semi-routed return flows from the four CDS regions of about 1,400 acre-ft/yr, could represent about 50 percent of the overdraft. 


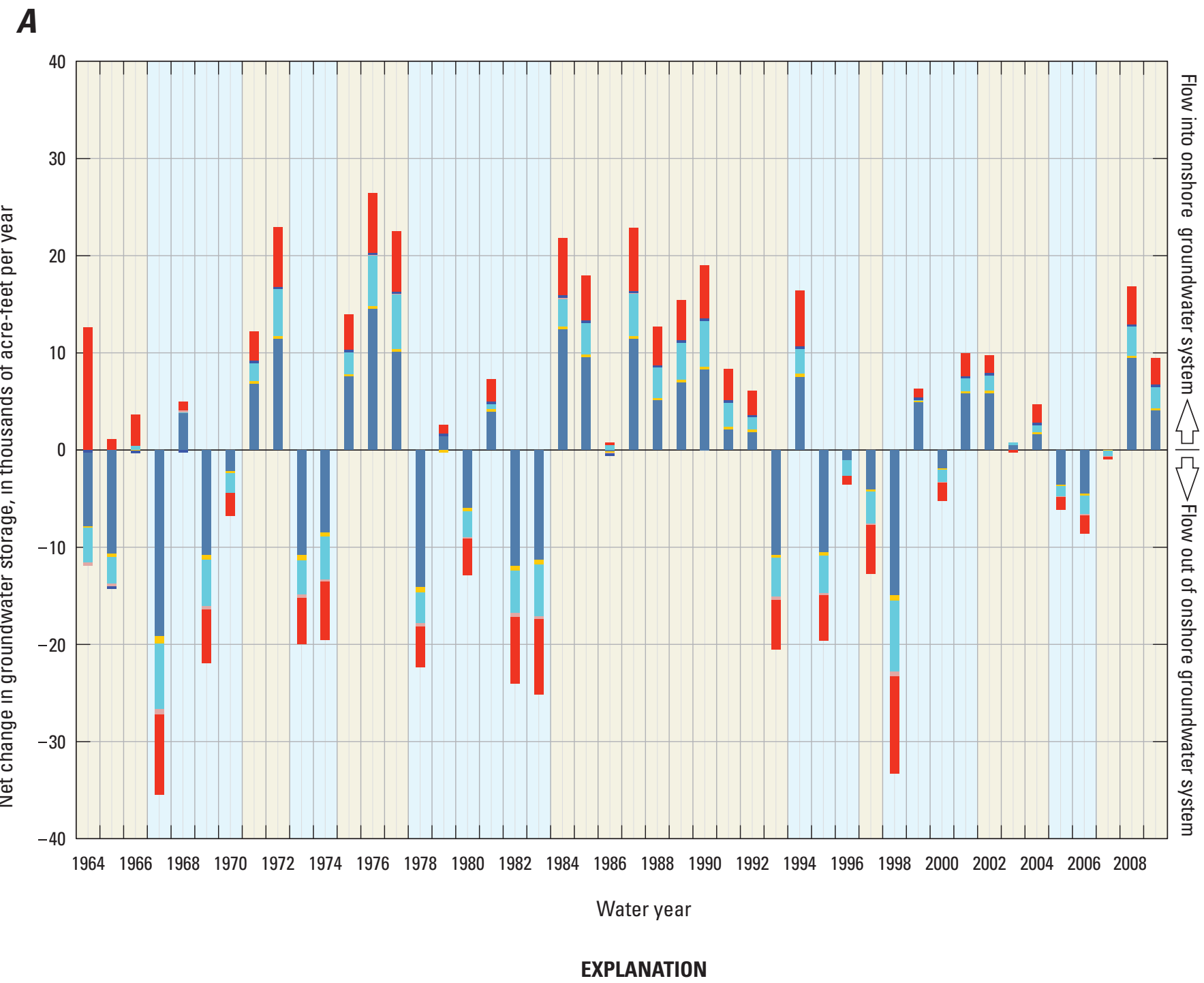

Net change in groundwater storage by onshore layers for Pajaro Valley, California

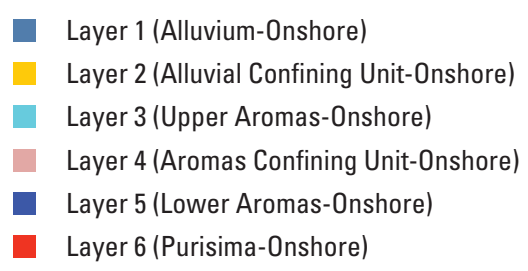

Recent precipitation cycles

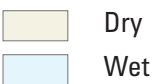

Figure 44. Temporal distribution of $A$, net changes in storage; and $B$, net coastal flows by major subregions as surrogate for seawater intrusion, Pajaro Valley, California. 


\section{B}

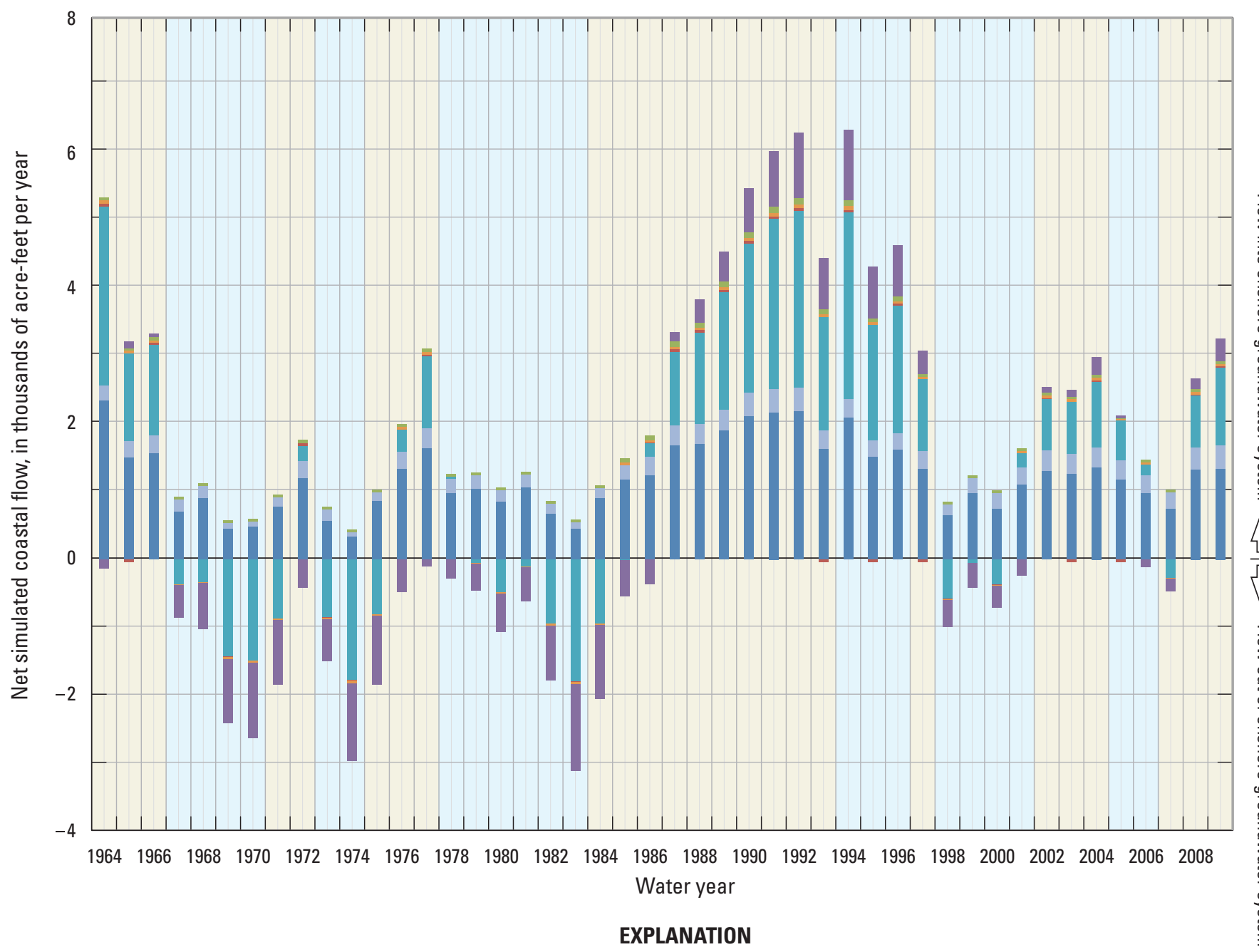

Net annual simulated coastal inflow by model-layer subregions; net negative inflow is an outflow from the onshore groundwater system

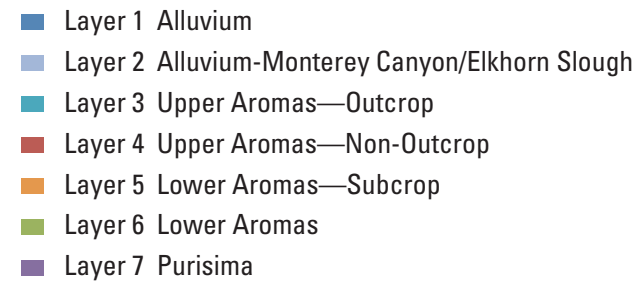

Recent precipitation cycles

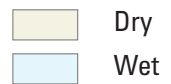

Figure 44. - Continued 


\section{Model Uncertainty, Limitations, and Potential Improvements}

The numerical flow model, PVHM, used to simulate the hydrologic system of the Pajaro Valley is a simplification of the real flow system, and as such has some inherent limitations. The accuracy of simulation results is related strongly to the quality and spatial distribution of input data and of measurements of the system (such as water levels, streamflow, and pumpage) used to constrain the calibration. The inflows and outflows in the model were a combination of measured values (specified inflows), adjustments to represent conceptualizations of the system, and values calculated through the use of the model code, MF-FMP2. Differences between simulated and actual hydrologic conditions arise from a number of sources and are collectively known as model error, which results in potential model uncertainty.

While the model was designed with the capability to be accurate at small spatial scales, the conceptual and numerical model include simplifications that currently restrict the reliable use of the model to regional and subregional levels of spatial analysis within seasonal to interannual temporal scales. Potential future refinements and enhancements would continue to improve the level of resolution and model accuracy. Proper design and calibration of flow models can minimize some of the inherent limitations, as can better estimates of inflows, outflows and changing spatial data such as land use. Limitations of the modeling software, assumptions made during model development, and results of model calibration and sensitivity analysis all are factors that may constrain the appropriate use of this model and can be used to highlight potential future improvements in the simulation of specific processes or the data used to simulate existing features.

Model discretization in space and time can be a potential source of error and uncertainty. Models represent a hydrologic system as a series of discrete spatial units, through which intrinsic properties and flows are assumed to be uniform. The use of a discretized model to represent a hydrologic system introduces limitations for features that occur at scales smaller than the discretization. Transient models are further discretized into a series of discrete units of time, during which specified hydrologic inflows and outflows are held constant. The use of monthly stress periods and biweekly time steps in the PVHM assumes that the variations of inflows and outflows and changes in water levels are piecewise linear changes. Changes at smaller time scales are not simulated, and thus are not discernible in the model results, which may contribute to some additional temporal uncertainty. The temporal scale used in the PVHM was expressly designed to separate the supply and demand components of water use and movement for agriculture.

Differences between simulated and measured hydrologic factors or properties also can arise from the numerical solution, which attempts to provide a cell-by-cell mass balance of inflows and outflows. Mass-balance errors are minimized by ensuring the model solution reaches a reasonable state of mass balance within each biweekly period. The biweekly time steps were used to remain consistent with the assumptions of the current version of FMP2. The cumulative mass balance of the model was within one percent of the total flow over the 46 years of simulation.

An additional component of model error arises from how well model-input values represent the actual hydrologic system. The accuracy of the calibrated model is contingent on the accuracy of the specified inflows and of the specified comparison flows. Model calibration provides a means to use comparisons to indirectly constrain the differences between the real-world and simulated mass flows. Thus, the degree to which a simulated condition provides a reasonable representation of the hydrologic system can be evaluated through comparing simulated hydrologic conditions with those observed in the field, which in turn provides a massconstrained calibration. The performance and accuracy of PVHM are constrained primarily by groundwater levels, streamflows and diversions, pumpage, and to a lesser degree streamflow losses and head differences. The model is used for developing a conceptual understanding of the flow system by quantifying the regional inflows and outflows and their relative proportions. Because the Pajaro Valley flow system is inherently complex, like all models, simplifying assumptions were made in developing and applying the numerical code, MF-FMP2. The model solves for average conditions within each 15 -acre cell for each two-week period with the parameters interpolated or extrapolated from measurements, and/or estimated during calibration. Thus, results from the model simulations should be interpreted sub-regionally to regionally at annual to interannual periods for comparative analysis and generalized estimates of flows. 
Several elements of the revised model remain uncertain and would require additional investigation to help further improve the accuracy of the simulation of groundwater and surface-water flow, regional storage changes, and the use and movement of water across the landscape. For example, some of the inputs to the Farm Process necessary for calculating water use remain uncertain, and model features such as pumpage may be sensitive to a few of these parameters (for example, crop coefficients, irrigation efficiencies, multiple cropping, and monthly to seasonal changes in land use). In particular, refining the distribution and change in landuse patterns to a monthly time scale would greatly increase accuracy of the simulation. Many of the actual stresses that are driven by land use varied throughout the simulation period at higher frequencies than those simulated using the multiyear estimates of land use. This is evident in the improved simulation results since 1992, when additional and shorter land-use periods were specified in the model. Likewise, highfrequency variations in stresses also are driven by climatic conditions and growing periods. Hence, the hydrologic responses occur seasonally and with climatic-driven events that occur over a year (for example, 1997) or multiple years. Because the land use was based on generalized classification for the early years and selected crop categories, some of the agricultural composite crop classes were replaced with the composite crop of identical extent from the land-use map for 2000. For example, where only cropland was specified, the composite crops interpreted on the 2000 land-use map were embedded. This assumes the farmer would be growing the same type of crop in a given area over the time frame of the hydrologic simulation when that map was used (table 2). In some cases, such as for orchards, this is generally a good assumption; in other cases, such as vegetable row or berry crops, the crops may have changed several times during the years represented by the land-use map. This is an aspect of the simulation that could be substantially improved in future refinements of the model. While we could have a better understanding of historical land use, these types of refinements would most improve current and future simulation capabilities. Estimates of $\mathrm{ET}_{\mathrm{h}}$ and growing periods are uncertain and could be better delineated, especially in terms of their relation to climate changes. Finally, natural vegetation represents between 43 and 55 percent of the land use, and as such was an important control for runoff and recharge in the upland regions of Pajaro Valley. A potential future refinement to the model would include separation of the natural vegetation into several land-use categories, such as foothill hardwood forests, upland scrub, and riparian vegetation. This may improve control of simulated recharge and runoff in these areas.

Some inflows, such as ungaged streamflow, remain relatively uncertain, and the simulation results could potentially benefit from improved estimates if additional capture of local runoff is a primary component of any revised BMP. Although estimation of the ungaged streamflow or linkage to a precipitation-runoff model was outside the scope of this study, such estimates or a linkage could improve the simulation of the streamflow network and streamflow infiltration in the mountain front regions. Thus, estimates of flows in Brown's, Casserly, Hughes, Green Valley, and Salsipuedes Creek as well as Shingle Mill and Mattos Gulch and the unnamed streams $(425,484,532)$ could be improved by better estimates of ungaged inflow from a rainfall-runoff model of the surrounding Santa Cruz Mountains (for example, see Flint and Flint, 2012).

Similarly, the use of improved water-delivery data would help to refine the accuracy of the supply and demand components for agricultural and urban use. For coastal agricultural supplies, this could include use of specific delivery data from the CDS to each WBS to help constrain the simulation of demand for agricultural water. This could also include better information on the hours of operation and pumping rates of wells within the CDS delivery system. Improved streamflow diversion data along the west branch of Corralitos Creek, Brown's Creek diversion data, and deliveries to the CDS by the linkage with the City of Watsonville delivery system would improve simulation of urban water use. These types of improvements would improve the ability of the PVHM to evaluate the BMP alternatives by further delineating when water is available and when it is delivered.

Hydrologic features that remain uncertain include the location and dates of recent potential displacements along some Zayante fault segments, selected hydraulic properties, and zonation of hydraulic properties. The PVHM model may benefit from refinement of the location of the trace of the Zayante fault, which may affect where the flow barrier occurs within the Purisima Formation below the aquifers that are actively pumped. The values of horizontal and vertical conductivities, and of storage properties input to the model, could be improved and made more accurate by additional field estimates. Additional estimates of horizontal hydraulic conductivity could be made on the basis of results of slug tests at monitoring-well sites or specific capacity approximations from single-aquifer supply wells to further constrain the model properties. The representation of sedimentary layering could be further improved in the model if simulations of groundwater flow in the perched system in the Corallitos area or near the ASR system are needed for solute-transport or particle-tracking simulations of groundwater flow. The zonation in the lower Aromas is currently based on textural subregions, but the extent of subregions and related hydraulic properties could be refined into separate regions north of the 
Pajaro River, within the Pajaro River floodplain region, and south of the river in Pajaro Valley. In addition, the data used to distribute the textural data becomes more uncertain with depth below the land surface, and the difference between simulated and measured heads also generally increases with depth. The information for the Purisima Formation may be especially uncertain as few wells currently produce from this unit in the Pajaro Valley. Thus, the textural database is more certain for the alluvium and upper Aromas and less certain for parts of the lower Aromas and Purisima Formation. All estimates in the texture database are uncertain extrapolations for the region offshore, for which no data currently exists.

Several of the processes within the model could also potentially allow for refined simulation of selected flow features. Improved simulation of multi-aquifer wells to account for partial penetration and better estimates of actual pumping capacities of all wells could increase the accuracy of simulated pumpage. Similarly, the simulation of runoff within the Farm Process could be enhanced to better simulate the intensity of wet-year winter precipitation events that would facilitate better estimates of runoff and tile-drain return flows to the Pajaro River.

Selected aquifer and land-use parameters also courld be refined during subsequent updates of the model to help improve model accuracy and flexibility. This could include the use of particle tracking to better constrain estimates of hydraulic properties, which would constrain estimates of seawater intrusion as well as the use of the new seawater intrusion interface (SWI2) package (Bakker and others, 2013) to better delineate the various sharp saltwater interfaces in each aquifer.

In summary, some potential enhancements that could improve the accuracy and reduce uncertainty of the simulation include, but are not limited to:

1. Improved temporal estimates of land use from seasonal to monthly;

2. Improved estimation and application of crop and irrigation properties;

3. Segregation of natural vegetation into multiple classes;

4. Improved estimates of ungaged stream inflows through linkage to precipitation-runoff model, coupled with additional measurements of runoff duration, location, and flow in ephemeral streams draining the uplands;

5. Improved delivery data for individual streamflow diversions and CDS flow components;

6. Refined location of the trace of the Zayante Fault;
7. Improved estimates of hydraulic properties through field tests;

8. Improved texture estimates at depth and offshore, and refined zonation of the Lower Aromas;

9. Improved simulation of multi-aquifer wells to account for partial penetration and farm well pumping capacities; and

10. Improved simulation of wet-year winter runoff and tiledrain return flows within FMP

Despite these potential limitations and potential for future improvements, the PVHM represents the most realistic, accurate, reliable means for understanding many aspects of the PVGB, and was designed for planning and evaluating various alternatives for managing water resources. While all models have limitations, the options for testing alternatives would be much more limited without the capabilities provided by PVHM. When used correctly; PVHM can help to continue developing understanding of the Pajaro Valley hydrologic system as more data and more capabilities are added.

The model also is capable of being used for BMP analysis and for sustainability analysis. The BMP analysis could look at the potential impact of the CDS in the years beyond 2002-09. The analysis could also include the hypothetical addition of other proposed project components, such as additional streamflow diversion to ASR system or infiltration ponds, additional capture of runoff for localized recharge, or additional recharge through well injection at the coast to reduce or prevent seawater intrusion, additional reuse of agricultural runoff and tile drain water, or the capture of additional treated water at Harkins Slough and its distribution through the CDS system

Sustainability analysis could be facilitated through coupling the MF-FMP2 model with the Groundwater Management Process (GWM) optimization model that could facilitate the ability to identify best water-management strategies. Addition of groundwater allotments to MF-FMP2 would facilitate the limitation of groundwater extractions within each WBS and for the entire Pajaro Valley. More importantly, this coupled approach would allow MF-FMP2 to assess the potential limits on agricultural extractions while the GWM would facilitate the additional potential analysis of the streamflow diversions and municipal pumpage. These factors collectively provide potential constraints on coastal inflows that are needed to systematically investigate sustainability that is subject to storage depletion and seawater intrusion driven by municipal and agricultural pumpage. This analysis could be used to reevaluate the previous BMP study (Smith, 2000) and provide updated estimates of these and other potential alternatives. 


\section{Summary and Conclusions}

Monterey Bay's Pajaro Valley is one of the most productive agricultural regions in the world; however, increases in population and changes to crops that consume additional water have increased the competition for water within the valley. This study provided a refined conceptual model, a geohydrologic framework, and a hydrologic model of the Pajaro Valley capable of being accurate at scales relevant to water management decisions that are being considered in the revision and updates to the Basin Management Plan (BMP). The model was designed to represent all of the natural and human components of the hydrologic system and related climatic factors, so that the components of the BMP are simulated to relatively good accuracy. Previously developed models were transformed into some of the parts of the new Pajaro Valley Hydrologic Model (PVHM), which incorporates new geohydrologic data, new hydrologic features, finer spatial and temporal discretization, hydraulic properties distributed on the basis of textural data, and a monthly varying and climatically land-use driven water budget for the period October 1963 through December 2009.

The conceptual model identified inflows and outflows that include the movement and use of water from natural and human components (fig. 2A). Inflows to the hydrologic cycle include precipitation and streamflow, as well as groundwater underflow from the landward regions north and south of the valley and from coastal inflow as seawater intrusion. Outflow from the valley's hydrologic system occurs as runoff from precipitation and irrigation focused as streamflow to the ocean, as groundwater underflow intermittently to the ocean and to the adjacent landward regions, as evapotranspiration, as water production of agricultural products, as waste water from municipal pumpage and municipal use, and as runoff from irrigation return flows and tile-drain flows. The recharge to the groundwater portion of the hydrologic cycle includes streamflow infiltration, deep percolation from precipitation and excess irrigation, and groundwater underflow. Discharge from the groundwater system includes pumpage for agricultural, municipal, and domestic use; evapotranspiration from natural vegetation and agricultural fields; tile-drain outflows from the valley floodplain regions; and intermittent underflow to the ocean and exfiltration to streams.

The revised geohydrologic framework refines the layering, extent, and textural distribution of the major aquifers and confining units within Pajaro Valley (fig. 3). The resulting layering delineates the alluvium, Upper and Lower Aromas, upper Purisima Formation, as well as confining units at the base of the alluvium and between the Upper and Lower
Aromas. Because all of the alluvium was combined into one composite layer, the additional upper confining units that may create locally perched zones in the Corralitos region were not delineated. Each of the PVHM layers was additionally subdivided into areal subregions on the basis of depositional environments or sediment texture (fig. 27).

The PVHM is a 6-layer hydrologic flow model that comprises 9,570 15-acre (250-meter-square) active cells. The model represents flow in the unconfined, semi-confined, and confined portions of the sediment-filled Pajaro Valley. The top two layers of the model represent the Alluvial Aquifer system that consists of an upper fine-grained unit and a lower coarse-grained unit of Quaternary age where it is present. Model layers 3, 4, and 5 represent the upper Aromas, a basal confining unit in the upper Aromas, and lower Aromas of Pleistocene age, respectively. The lowest model layer generally represents the upper $300 \mathrm{~m}$ of the Purisima Formation of Pliocene age. In all these layers, a sediment texture model was used to define the percentage of coarse-grained deposits in each model cell based on drillers', geologic, and geophysical logs. In combination with subregional multipliers and layer-specific hydraulic properties, this texture model was used to estimate all hydraulic properties within each geohydrologic unit.

The groundwater flow system is characterized by a layered sedimentary system with vertical hydraulic gradients resulting from the combined effects of the application of irrigation water at the land surface plus groundwater pumpage. Agricultural pumpage is a major component to simulated outflow that is often poorly recorded; therefore, a coupled farm-process model is used to estimate historical pumpage for water-balance subregions as well as the delivery of surface water to and from the Harkins Slough Aquifer-Storage-andRecovery System (HS-ASR) and related Coastal Distribution System (CDS) since 2002. Wells perforated across the confining layers in the Alluvial and Aromas Aquifers and the upper Purisima Formation were simulated as multi-node wells, which allows for flow through wells across these aquifers in addition to vertical flow across the hydrogeologic layers. The new integrated hydrologic model includes new water-balance subregions; delineation of natural, municipal, and agricultural land use; streamflow networks; and groundwater flow systems (fig. 2). The redefinition of the geohydrologic framework (including the internal architecture of the deposits) and incorporation of these units into the simulation of the regional groundwater flow system indicate the importance of the basal confining units in the alluvial deposits and between the upper and lower Aromas Sand with respect to regional groundwater flow, locations of recharge, and the effects of development. 
The PVHM model, using MODFLOW with the Farm Process (MF-FMP2), allows for the simulation and assessment of the use and movement of water that includes the newer components of the HS-ASR system and CDS. The model is capable of being accurate at seasonal to interannual time frames and subregional to valley-wide spatial scales that allow for analysis of the assessment of the groundwater hydrologic budget for the water years 1964-2009, as well as potential assessment of the BMP components and sustainability analysis of conjunctive use. Because climate and sea-level change factors are embedded in the model, it can also be used for analysis of climate change and related sea-level rise analyses.

The model was developed and calibrated in phases, which included development of a revised conceptual model of the flow system, reevaluation of the previous PVIGSM transformed into MODFLOW, implementation of the new geohydrologic model and conceptual model, and calibration of the transient flow model. The model provides a good representation of the regional flow system. Maps of simulated and measured water-level elevations indicate regions with water levels below sea level in the Alluvium and Aromas layers.

Simulated changes in storage over time show that, prior to the 1984-92 dry period, significant withdrawals from storage occurred only during drought years (1976-77 and 1988-92). Since 1993, growers in Pajaro Valley have increasingly used groundwater in conjunction with increases in acreage planted in strawberries and vegetable row crops and up to triple cropping or multiple harvests of strawberries and selected vegetable row crops. Simulated groundwater flow indicates gradients between layers fluctuate between upward flow and downward flow in several areas of the Pajaro Valley as recharge and pumpage rates change seasonally and annually and represent combination of interlayer flow and wellbore flow.

The results from the PVHM simulations are similar in some respects to results from models developed in earlier studies, including confirmation of long-term overdraft conditions in the PVGB. In particular, most recharge and pumpage occurs in the inland regions along with the largest fractions of storage depletion and coastal inflow as seawater intrusion. While the overdraft has varied seasonally and with changing climate, it is estimated to have averaged about 12,950 acre-ft per year over the past 43 water years. Climatically driven factors can greatly affect inflows, outflows, and water use by as much as a factor of two between wet and dry years. While both coastal inflows and outflows are occurring for selected years and aquifers, the simulated net coastal inflow that represents seawater intrusion ranges from about 1,000 to more than 6,000 acre-ft/yr. The quantity of storage loss in PVGB aquifers that is associated with seawater intrusion is likely to be larger than this, because of salty water mixing with ambient groundwater.

The expansion of the hydrologic monitoring networks in the Pajaro Valley indicates the importance of these networks to understanding changes in groundwater flow, streamflow, and streamflow infiltration. In particular, the monitoring of streamflow, groundwater pumpage, and groundwater levels throughout the valley would help to document the state of the resources as well as provide valuable comparisons to model performance. The addition of more mapping of cropping on a seasonal to monthly basis may greatly improve the performance of the model.

Overall, groundwater supplies most of the agricultural demand in the initial part of the growing season, and is augmented by precipitation during wet winter and spring seasons. In addition, the amount of groundwater used for irrigation varies from year to year in response to climate variation, and can increase dramatically in dry year. Part of the coastal groundwater demand is beign replaced by the deliveries from the CDS system since 2002.

The HS-ASR and RWF combined with the CDS system now replace some of the demand for coastal groundwater pumpage. The ASR system was simulated for the years 2002-09, and this operation supplanted about 1,290 acre-ft of coastal pumpage combined with 6,200 acre-ft of additional deliveries from supplemental wells, recycled water facility, and city connection deliveries through the CDS. While the CDS delivery capacity is much greater, the initial projects were assumed to deliver 8.8 million cubic meters (7,150 acre-ft) of water per year to coastal farms within the Pajaro Valley, provided there are enough locations to receive the full delivery and if all the local supply components were fully available for this purpose. This could represent about 15 percent of the (48,300 acre-ft; 59.6 million $\left.\mathrm{m}^{3}\right)$ average agricultural pumpage for the period 2005 to 2009. Combined with the potential capture and reuse of some of the return flows and tile-drain flows, this could represent an almost 70 percent reduction of average overdraft for the entire valley and a large part of the coastal pumpage.

The model generally fits the observations and replicates the measured pumpage within a few percent. This model provides a tool that can be used to analyze the new ASR system and CDS components of the PVWMA BMP components, and the sustainability of the use of water resources subject to changing demands and uses. 


\section{References Cited}

Allen, J.E., 1946, Geology of the San Juan Bautista quadrangle, California: California Division of Mines Bulletin 133, 112 pp.

Allen, R.G., Pereira, L.S., Raes, Dirk, and Smith, Martin, 1998, Crop evapotranspiration - Guidelines for computing crop water requirements: Food and Agriculture Organization of the United Nations, Irrigation and Drainage Paper 56, 300 p., http://www.fao.org/docrep/x0490e/x0490e00.htm.

Anderson, J.R., Hardy, E.E., Roach, J.T., and Witmer, R.E., 1976, A land use and land cover classification system for use with remote sensor data: U.S. Geological Survey Professional Paper 964, 28 p., http://pubs.er.usgs.gov/publication/pp964.

Bakker, Mark, Schaars, Frans, Hughes, J.D., Langevin, C.D., and Dausman, A.M., 2013, Documentation of the seawater intrusion (SWI2) package for MODFLOW: U.S. Geological Survey Techniques and Methods, book 6, chap. A46, 47 p., http://pubs.usgs.gov/tm/6a46/.

Belitz, Kenneth, Phillips, S.P., and Gronberg, J.M, 1993, Numerical simulation of ground-water flow in the central part of the western San Joaquin Valley, California: U.S. Geological Survey Water-Supply Paper 2396, 69 p., http://pubs.er.usgs.gov/publication/wsp2396.

Belitz, Kenneth, and Phillips, S.P., 1995, Alternative to agricultural drains in California's San Joaquin Valley: Results of a regional-scale hydrogeologic approach: Water Resources Research, v. 31, no. 8, p. 1845-1862, http://dx.doi.org/10.1029/95WR01328.

Bond, L.D., 1986, Origins of seawater intrusion in a coastal aquifer - A case study of the Pajaro Valley, California: Master's Thesis for Department of Applied Earth Sciences, Stanford University, p. 40.

Bond, L.D., and Bredehoeft, J.D., 1987, Origins of seawater intrusion in a coastal aquifer-A case study of the Pajaro Valley, California: Journal of Hydrology, v. 92, No.3-4, p. 363-388, http://dx.doi.org/ 10.1016/0022-1694(87)90024-2.

Brabb, E.E., Graham, S., Wentworth, C., Knifong, D., Graymer, R., and Blissenbach, J., 1997, Geologic Map of Santa Cruz County, California: A Digital Database: U.S. Geological Survey Open-File Report 97-489, 15 p., http://pubs.er.usgs.gov/publication/ofr 97489.

Brouwer, C., and Heibloem, M, 1986, Irrigation Water Management: Irrigation Water Needs: Food and Agriculture Organization of the United Nations, Land and Water Development Division, Training manual no.3, http://www.fao.org/docrep/s2022e/s2022e00.HTM.
Brouwer, C., Goffeau, A., and Heibloem, M., 1985, Irrigation Water Management: Training manual no. 1 - Introduction into Irrigation: Food and Agriculture Organization of the United Nations, Land and Water Development Division, http://www.fao.org/docrep/r4082e/r4082e00.htm.

Brown and Caldwell, 1976, Groundwater conditions in the Pajaro Valley - Santa Cruz Wastewater Facility Planning Study, Consultants Report to PVWMA by Brown and Caldwell, Walnut Creek, CA., 62 p.

Brush, C.F., Belitz, Kenneth, and Phillips, S.P., 2004, Estimation of a water budget for 1972-2000 for the Grasslands Area, central part of the western San Joaquin Valley, California: U.S. Geological Survey Scientific Investigations Report 2004-5180, 59 p., http://pubs.er.usgs.gov/publication/sir20045180.

Brush, C.F.; Belitz, Kenneth, Phillips, S.P., Burow, K.R., and Knifong, D.L., 2006, MODGRASS: Update of a ground-water flow model for the central part of the western San Joaquin Valley, California: U.S. Geological Survey Scientific Investigations Report 2005-5290, 81 p., http://pubs.er.usgs.gov/publication/sir20055290.

Burow, K.R., Shelton, J.L., Hevesi, J.A., and Weissmann, G.S., 2004, Hydrogeologic characterization of the Modesto area, San Joaquin Valley, California: U.S. Geological Survey Scientific Investigations Report 2004-5232, 62 p., http://pubs.er.usgs.gov/publication/sir20045232.

California State Water Resources Board (CWRCB), 1953, Santa Cruz-Monterey Counties Investigation: California State Water Resources Board Bulletin No. 5, 230 p., http://www.water.ca.gov/waterdatalibrary/docs/historic/ Bulletins/Bulletin_5/Bulletin_5_1953.pdf.

California Department of Water Resources (CADWR), 1994, California Water Plan Update: Bulletin 160-93, California Department of Water Resources, Sacramento, CA, http:// www.waterplan.water.ca.gov/previous/b160-93/TOC.cfm.

California Department of Water Resources (CADWR), 1997, 1997 land use for Monterey, Santa Cruz, and San Benito Counties, last accessed July 2011, http://www.water.ca.gov/landwateruse/lusrvymain.cfm.

California Department of Water Resources (CADWR), 2000, Explanations of land use attributes used in database files associated with shape files: Land and Water Use Section, $11 \mathrm{p}$.

California Department of Water Resources, 2003, California's Groundwater: Bulletin 118 Update 2003, Ch. 6, Basic groundwater concepts, p.80-104, retrieved May 1, 2012, from http://www.water.ca.gov/pubs/ groundwater/bulletin_118/california\%27s_groundwater bulletin_118_-_update_2003_/bulletin118-chapter6.pdf. 
California Department of Water Resources (CADWR), 2007, California Irrigation Management Information System: http://www.cimis.water.ca.gov/cimis/welcome.jsp.

Clark, J.C., 1981, Stratigraphy, paleontology, and geology of the central Santa Cruz Mountains, California Coast Ranges, U.S. Geological Survey Professional Paper 1168, 51 p., http://pubs.er.usgs.gov/publication/pp1168.

Climate Source, 2006, Precipitation data from PRISM data, accessed July 12, 2006, at http://www.climatesource.com/.

Dimitrakopoulos, Roussos, and Desbarats, A.J., 1993, Geostatistical modeling of gridblock permeabilities for 3D reservoir simulators: SPE Reservoir Engineering, v.8, no.1, p. 13-18, http://dx.doi.org/10.2118/21520-PA.

Dupre, W.R., 1975, Quaternary history of the Watsonville lowlands north-central Monterey Bay region, California: unpublished Ph.D. dissertation, Stanford University, 145 p.

Dupre, W.R., 1990, Quaternary geology of the Monterey Bay region, California in Garrison R.E., Greene H.G., Hicks K.R., Weber, G.E., and Wright, T.L., eds., Geology and tectonics of the central California coast region, San Francisco to Monterey: American Association of Petroleum Geologists, Volume and Guidebook GB67, Pacific Section, Bakersfield, California, p. 185-191.

Droogers, Peter, and Allen, R.G., 2002, Estimating reference evapotranspiration under inaccurate data conditions, Journal of Irrigation and Drainage Systems, v.16, no.1, p. 33-45, http://dx.doi.org/10.1023/A:1015508322413.

Eittreim, S.L., Anima, R.J., Stevenson, A.J., 2002, Seafloor geology of the Monterey Bay area continental shelf: Marine Geology, v. 181, no.1-3, p. 3-34, http://dx.doi.org/10.1016/S0025-3227(01)00259-6.

Eittreim, S.L., Anima, R.J., Stevenson, A.J., and Wong, F.L., 2000, Seafloor rocks and sediments of the Continental Shelf from Monterey Bay to Point Sur, California, U.S. Geological Survey Miscellaneous Field Studies Map MF-2345, Online version 1.0, http://pubs.er.usgs.gov/publication/mf 2345 .

Environmental Science Association, 2006, Soquel Creek Water District Integrated Resources Plan, March 2006, variously paged.

Essaid, H.I., 1992, Simulation of freshwater and saltwater flow in the coastal aquifer system of the Purisima Formation in the Soquel-Aptos Basin, Santa Cruz County, California: U.S. Geological Survey Water-Resources Investigation Report 91-4148, 35 p., http://pubs.er.usgs.gov/publication/wri914148.
Faunt, C.C., Hanson R.T., Belitz, Kenneth, Schmid, Wolfgang, Predmore, S.P., Rewis, D.L., and McPherson, Kelly, 2009a, Numerical model of the hydroligic landscame and groundwater flow in California's Central Valley in Groundwater availability of the Central Valley Aquifer, California, Faunt, C.C., ed., U.S. Geological Survey Professional Paper 1766, Ch.C, p. 121-212, http://pubs.er.usgs.gov/publication/pp1766.

Faunt, C.C., Belitz, Kenneth, and Hanson, R.T., 2009b , Development of a three-dimensional model of sedimentary texture in valley-fill deposits of the Central Valley, California, USA: Hydrogeology Journal, v.18, no. 3, p. 625-649, http://dx.doi.org/10.1007/s10040-009-0539-7.

Flint, L.E., and Flint, A.L., 2012, Simulation of climate change in San Francisco Bay Basins, California: Case studies in the Russian River Valley and Santa Cruz Mountains: U.S. Geological Survey Scientific Investigations Report 2012-5132, 55 p., http://pubs.er.usgs.gov/publication/sir20125132.

Fio, J.L., and Leighton, D.A., 1995, Geohydrologic framework, historical development of the groundwater system, and general hydrologic and water-quality conditions in 1990, South San Francisco Bay and Peninsula area, California: U.S. Geological Survey Open-File Report 94-357, 46 p., http://pubs.er.usgs.gov/publication/ofr94357.

Fugro West, Inc., 1995, North Monterey County Hydrogeologic Study: Volume I-Water Resources, Consultants report to Monterey County Water Resources Agency by Fugro West, Inc., October 1995, 60 p.

Fugro West, Inc., 1996, North Monterey County Hydrogeologic Study: Volume II-Critical Issues Report and Interim Management Plan, Consultants report to Monterey County Water Resources Agency, North County Inter-Agency Committee by Fugro West Inc., May 1996, $60 \mathrm{p}$.

Geiben, Helmut, 1998, Watershed analysis tool for environmental review (WATER): California Coastal Commission, 37 p., http://www.ccjdc.org/resources/ WaterData/userguide/CDUsersGuide.pdf.

Gibeault, V.A., Cocker-ham, S., Henry, J.M, and Meyer, J., 1989, California Turfgrass: It's use, water requirement and irrigation: California Turfgrass Culture, University of California Cooperative Extension, v.39, no.3-4, 14 p., https://agops.ucr.edu/turf/publications/ctc/ctc39_34.pdf.

Gilliom, R.J., Barbash, J.E., Crawford, C.G., Hamilton, P.A., Martin, J.D., Nakagaki, Naomi, Nowell, L.H., Scott, J.C., Stackelberg, P.E., Thelin, G.P., and Wolock, D.M, 2006, Pesticides in the nation's streams and ground water, 1992-2001: U.S. Geological Survey Circular 1291, 180 p., http://pubs.er.usgs.gov/publication/cir1291. 
Green, H.G., 1970, Geology of the southern Monterey Bay and its relationship to the ground water basin and salt water intrusion: U.S. Geological Survey Open-File Report 70-141, 50 p., http://pubs.er.usgs.gov/publication/ofr 70141.

Halford, K.J., and Hanson, R.T., 2002, User guide for the drawdown-limited, multi-node well (MNW) package for the U.S. Geological Survey's modular three-dimensional finite-difference ground-water flow model, versions MODFLOW-96 and MODFLOW-2000: U.S. Geological Survey Open-File Report 2002-293, 33 p., http://pubs.er.usgs.gov/publication/ofro2293.

Hanson B.R., and Bendixen, Warren, 2004, Drip irrigation evaluated in Santa Maria Valley strawberries: California Agriculture, University of California, v.58, no.1, p. 48-53, http://dx.doi.org/10.3733/ca.v058n01p48.

Hanson, R.T., 1989, Aquifer-system compaction, Tucson Basin and Avra Valley, Arizona: U.S. Geological Survey Water-Resources Investigation Report 88-4172, 69 p., http://pubs.er.usgs.gov/publication/wri884172.

Hanson, R.T., and Leake, S.A., 1999, Documentation for HYDMOD; A program for extracting and processing time-series data from the U.S. Geological Survey's modular three-dimensional finite-difference ground-water flow model: U.S. Geological Survey Water-Resources Investigations Report 98-564, 57 p., http://pubs.er.usgs.gov/publication/ofr98564.

Hanson, R.T., Anderson, S.R., and Pool, D.R., 1990, Simulation of ground-water flow and potential land subsidence, Avra Valley, Arizona: U.S. Geological Survey Water-Resources Investigation Report 90-4178, 41 p., http://pubs.er.usgs.gov/publication/wri904178.

Hanson, R.T., and Benedict J.F., 1994, Simulation of groundwater flow and potential land subsidence, upper Santa Cruz River Basin, Arizona: U.S. Geological Survey WaterResources Investigation Report 93-4196, 47 p., http://pubs.er.usgs.gov/publication/wri934196.

Hanson, R.T., Everett, R.R., Newhouse, M.W., Crawford, S.M., Pimentel, M.I., and Smith, G.A., 2002, Geohydrology of a deep-aquifer system monitoring-well site at Marina, Monterey County, California: U.S. Geological Survey Water-Resources Investigation Report 2002-4003, 73 p., http://pubs.er.usgs.gov/publication/wri024003.

Hanson, R.T., Martin, Peter, and Koczot, K.M., 2003, Simulation of ground-water/surface-water flow in the Santa Clara-Calleguas ground-water basin, Ventura County, California: U.S. Geological Survey Water-Resources Investigations Report 2002-4136, 214 p., http://pubs.er.usgs.gov/publication/wri024136.
Hanson, R.T., 2003a, Geohydrologic framework of recharge and seawater intrusion in the Pajaro Valley, Santa Cruz and Monterey Counties, California: U.S. Geological Survey Water-Resources Investigation Report 2003-4096, 88 p., http://pubs.er.usgs.gov/publication/wri034096.

Hanson, R.T., 2003b, Geohydrology of recharge and seawater intrusion in the Pajaro Valley, Santa Cruz and Monterey Counties, California: U.S. Geological Survey Fact Sheet 044-03, 4 p., http://pubs.er.usgs.gov/publication/fs04403.

Hanson, R.T., Li, Zhen, and Faunt C.C,, 2004, Documentation of the Santa Clara Valley regional groundwater/surface-water flow model, Santa Clara Valley, California: Scientific Investigations Report 2004-5231, 85 p., http://pubs.er.usgs.gov/publication/sir20045231.

Hanson, R.T., Newhouse, M.W., and Dettinger, M.D., 2004, A methodology to assess relations between climate variability and variations in hydrologic time series in the southwestern United States: Journal of Hydrology, v.287, no.1-4, p. 252269, http://dx.doi.org/10.1016/j.jhydrol.2003.10.006.

Hanson, R.T., Dettinger, M.D., and Newhouse, M.W., 2006, Relations between climate variability and hydrologic time series from four alluvial basins across the southwestern United States: Hydrogeology Journal, v.14, no.7, p. 11221146, http://dx.doi.org/10.1007/s10040-006-0067-7.

Hanson, R.T., Schmid, Wolfgang, Lear, Jonathan, and Faunt, C.C., 2008, Simulation of an aquifer-storage-and-recovery (ASR) system using the farm process in MODFLOW for the Pajaro Valley, Monterey Bay, California: Modflow and More 2008 - Ground Water and Public Policy, Golden, CO, May $18-21,2008$, p. 501-505, http://www.pvwma.dst.ca.us/hydrology/assets/ASR_FMP_ PVWMA_Hansonetal_FINAL.pdf.

Hanson, R.T., Izbicki, J.A., Reichard, E.G., Edwards, B.D., Land, Michael, and Martin, Peter, 2009, Comparison of groundwater flow in southern California coastal aquifers: Ch.5.3, in Earth Science In The Urban Ocean: The Southern California Continental Borderland, eds. Lee, H.J. and Normark, B., Geological Society of America Special Papers, v.454, p. 345-373, http://dx.doi.org/ 10.1130/2009.2454(5.3).

Hanson, R.T., Schmid, Wolfgang, Faunt, C.C., and Lockwood, B., 2010, Simulation and analysis of conjunctive use with MODFLOW's farm process: Groundwater, v.48, no.5, p. 674-689, http://dx.doi.org/10.1111/j.17456584.2010.00730.x.

Hanson, R.T., Flint, L.E., Flint, A.L., Dettinger, M.D., Faunt, C.C., Cayan, Dan, and, Schmid, Wolfgang, 2012, A method for physically based model analysis of conjunctive use in response to potential climate changes: Water Resources Research, v.48, no.6, 23 p., http://dx.doi.org/10.1029/2011WR010774. 
Harbaugh, A.W., 2005. MODFLOW-2005: the U.S. Geological Survey modular ground-water modelthe ground-water flow process: U.S. Geological Survey Techniques and Methods 6-A16, variously paginated, http://pubs.er.usgs.gov/publication/tm6A16.

Harbaugh, A.W., Banta, E.R., Hill, M.C., and McDonald, M.G., 2000, MODFLOW-2000, U.S. Geological Survey modular ground-water model-User guide to modularization concepts and the ground-water flow process: U.S. Geological Survey Open-File Report 2000-92, 121 p., http://pubs.er.usgs.gov/publication/ofr200092.

Hargreaves, G.H., 1994, Defining and using reference evapotranspiration: Journal of Irrigation and Drainage Engineering, v.120 no.6, p. 1132-1139, http://dx.doi. org/10.1061/(ASCE)0733-9437(1994)120:6(1132).

Hargreaves, G.H., and Samani, Z.A., 1982, Estimating potential evapotranspiration: Journal of the Irrigation and Drainage Division ASCE, v.108, no.3, p. 225-230.

Hargreaves, G.H., and Samani, Z.A., 1985, Reference crop evapotranspiration from temperature: Applied Engineering in Agriculture v.1, no.2, p. 96-99, http://dx.doi.org/10.13031/2013.26773.

Hargreaves, G.H., and Allen, R.G., 2003, History and evaluation of the Hargreaves evapotranspiration equation: Journal of Irrigation and Drainage Engineering, v.129, no.1, p. 53-63, http://dx.doi.org/10.1061/(ASCE)07339437(2003)129:1(53).

Hargreaves, G.L., Hargreaves, G.H., and Riley, J.P., 1985, Irrigation water requirements for Senegal River Basin: Journal of Irrigation and Drainage Engineering, v.111, no.3, p. 265-275, http://dx.doi.org/10.1061/(ASCE)07339437(1985)111:3(265).

Hatch, C.E., Fisher, A.T., Revenaugh, J.S., Constantz, Jim, and Ruehl, Chris, 2006, Quantifying surface watergroundwater interactions using time series analysis of streambed thermal records: Method development: Water Resources Research, v.42, no.10, 14 p., http://dx.doi.org/10.1029/2005WR004787.

Hatch, C.E., Fisher, A.T., Ruehl, C.R., and Stemler, Greg, 2010, Spatial and temporal variations in streambed hydraulic conductivity quantified with time-series thermal methods: Journal of Hydrology, v.389, no.3-4, p. 276-288, http://dx.doi.org/10.1016/j.jhydrol.2010.05.046.

Hickey, J.J., 1968, Hydrogeologic study of the Soquel-Aptos area, Santa Cruz County, California: U.S. Geological Survey Open-File Report 68-129, 48 p., http://pubs.er.usgs.gov/publication/ofr68129.

Hidalgo, H.G., Cayan, D.R., and Dettinger, M.D., 2005, Sources of variability of evapotranspiration in California: Journal of Hydrometeorology, v.6, no.1, p. 3-19, http://dx.doi.org/10.1175/JHM-398.1.
Hill, M.C., Banta, E.R., Harbaugh, A.W., and Anderman, E.R., 2000, MODFLOW-2000, The U.S Geological Survey modular ground-water model; User guide to the observation, sensitivity, and parameter-estimation processes and three post-processing programs: U.S. Geological Survey Open-File Report 2000-184, 209 p., http://pubs.er.usgs.gov/publication/ofr00184.

Hill, M.C., and Tiedeman, C.R., 2007, Effective groundwater model calibration: With analysis of data, sensitivities, predictions, and uncertainty: Wiley and Sons, New York, New York, $455 \mathrm{p}$.

Hill, M.C., 1990, Preconditioned conjugate-gradient 2 (PCG2), a computer program for solving ground-water flow equations: U.S. Geological Survey Water-Resources Investigations Report 90-4048, 43 p., http://pubs.er.usgs.gov/publication/wri 904048.

Hsieh, P.A., and Freckleton, J.R., 1993, Documentation of a computer program to simulate horizontal-flow barriers using the U.S. Geological Survey's modular three-dimensional finite-difference ground-water flow model: U.S. Geological Survey Open-File Report 92-477, 32 p., http://pubs.er.usgs.gov/publication/ofr 92477.

HydroMetrics LLC, 2009, Groundwater levels to protect against seawater intrusion and store freshwater offshore: Consultants report to Soquel Creek Water District, January 2009, $49 \mathrm{p}$.

Jacob, C. E., 1940, On the flow of water in an elastic artesian aquifer: Transactions of the American Geophysical Union, v. 21 , p. $574-586$.

Jachens, R.L., 2006, 1906 Ground motion simulations: accessed May 29, 2007, http://earthquake.usgs.gov/ regional/nca/3Dgeologic/index.php.

Jensen, D.T., Hargreaves, G.H., Temesgen, B., and Allen, R.G., 1997, Computation of ETo under nonideal conditions: Journal of Irrigation and Drainage Engineering, v.123, no.5, p. 394-400, http://dx.doi.org/10.1061/ (ASCE)0733-9437(1997)123:5(394).

J.H. Kleinfelder and Associates, 1983, Recharge of alluvial aquifers from the Pajaro River channel, Pajaro River, California, Consultants Report to Association of Monterey Bay Area Governments, August 1983, 36 p.

Johnson, M.J., 1982, Public hearing regarding critical overdraft in the Santa Cruz-Pajaro ground-water basin: U.S. Geological Survey Written Testimony submitted to California Department of Water Resources at public hearings in Watsonville, California, October 1982, 8 p. 
Johnson, M.J., 1983, Ground water in the north Monterey County, California, 1980: U.S. Geological Survey WaterResources Investigations Report 83-4023, 37 p., http://pubs.er.usgs.gov/publication/wri834023.

Johnson, M.J., Londquist, C.J., Laudon, Julie, and Mitten, H.T., 1988, Geohydrology and mathematical simulation of the Pajaro Valley aquifer system, Santa Cruz and Monterey counties, California: U.S. Geological Survey Water-Resources Investigations Report 87-4281, 62 p., http://pubs.er.usgs.gov/publication/wri874281.

Johnson, N.M., 2006, Supplement to Hydrogeologic Conceptual Model, Technical memorandum report to Central Water District, December 2006, 46 p.

Johnson, N.M., Williams, Derrik, Yates, E.B., and Thrupp, Gordon, 2004, Groundwater assessment of alternative conjunctive use scenarios: Technical memorandum 2: Hydrogeologic conceptual model: Consultants report to Soquel Creek Water District, September 2004, variously paged, http://www. soquelcreekwater.org/district-reports/TM2-ReportText.pdf.

Lear, J., 2001, PVWMA State of the Basin Report: PVWMA Agency report, variously paged.

Laudon, Julie, and Belitz, Kenneth, 1991, Texture and depositional history of late Pleistocene-Holocene alluvium in the central part of the western San Joaquin Valley, California: Bulletin of the Association of Engineering Geologists, v.28, no.1, pp. 73-88.

Leighton, D.A., Fio, J.L., and Metzger, L.F., 1995, Database of well and areal data, South San Francisco Bay and Peninsula area, California: U.S. Geological Survey Water-Resources Investigations Report 94-4151, 47 p., http://pubs.er.usgs.gov/publication/wri944151

Luhdorff \& Scalmanini, 1987a, Pajaro Valley ground-water investigations - Phase I: Consultants report to Pajaro Valley Water Management Agency, January 1987, variously paged.

Luhdorff \& Scalmanini, 1987b, Pajaro Valley ground-water investigations - Phase II: Consultants report to Pajaro Valley Water Management Agency, January 1987, variously paged.

Luhdorff \& Scalmanini, 1988, Pajaro Valley ground-water investigations - Implementation of dedicated ground-water monitoring: Consultants report to Pajaro Valley Water Management Agency, November 1988, 26 p.

Mann, J.F., 1988, Regarding overdraft and seawater intrusion: Letter to General Manager of Pajaro Valley Water Management Agency, January 1988, 8 p.
McDonald, M.G., and Harbaugh, A.W., 1988, A modular three-dimensional finite-difference ground-water flow model: U.S. Geological Survey Techniques of WaterResources Investigations, Book 6, Ch.A1, 586 p., http://pubs.er.usgs.gov/publication/twri06A1.

Monterey Bay Aquarium Research Institute (MBARI), 2000, various coverages, accessed August 10, 2001, http://www.mbari.org/data/mapping/mapping.htm.

Montgomery, J.M., 1990, Pajaro Valley water augmentation study, Preliminary supplemental water source analysis: Consultants report to Pajaro Valley Water Management Agency by James M. Montgomery, Consulting Engineers, October 1990, variously paged. Montgomery Watson, 1993a, Documentation and user's manual for integrated groundwater and surface water model: Montgomery Watson, variously paged.

Montgomery Watson, 1993b, Pajaro Valley Water Management Agency_-Pajaro Valley ground water-surface water model update: Montgomery Watson consultant report to Pajaro Valley Water Management Agency, September 1993, variously paged.

Muir, K.S., 1972, Preliminary report on geology and ground water of the Pajaro Valley area, Santa Cruz and Monterey counties, California: U.S. Geological Survey Open-File Report 73-199, 80 p., http://pubs.er.usgs.gov/publication/ofr73199.

Muir, K.S., 1974, Seawater intrusion, ground-water pumpage, ground-water yield, and artificial recharge of the Pajaro Valley area, Santa Cruz and Monterey counties, California: U.S. Geological Survey WaterResources Investigations 74-9, 36 p., http://pubs.er.usgs.gov/publication/wri749.

Muir, K.S., 1977, Initial assessment of the groundwater resources in the Monterey Bay region, California: U.S. Geological Survey WaterResources Investigations 77-46, 33 p., http://pubs.er.usgs.gov/publication/wri7746.

Muir, K.S., and Johnson, M.J., 1979, Classification of ground-water recharge potential in the three parts of Santa Cruz County, California: U.S. Geological Survey WaterResources Investigations Open-File Report 79-1065, 1 sheet, http://pubs.er.usgs.gov/publication/ofr791065.

Newhouse, M.W., Hanson, R.T., Wentworth, C.M., Everett, R.R., Williams, C.F., Tinsley J.C., Noce, T.E., and Carkin, B.A., 2004, Geologic, water-chemistry, and hydrologic data from multiple-well monitoring sites and selected water-supply wells in the Santa Clara Valley, California, 1999-2003: U.S. Geological Survey Scientific Investigations Report 2004-5250, 142 p., http://pubs.er.usgs.gov/publication/sir20045250. 
Niswonger, R.G., and Prudic, D.E., 2005, Documentation of the streamflow-routing (SFR2) package to include unsaturated flow beneath streams-A modification to SFR1: U.S. Geological Survey Techniques and Methods 6-A13, 51 p., http://pubs.er.usgs.gov/publication/tm6A13.

National Oceanographic and Atmospheric Administrations (NOAA) Tides and Currents, 2012, last accessed January 2012, http://tidesandcurrents.noaa.gov/.

Orgaz, F., Fernández, M.D., Bonachela, S., Gallardo, M, Fereres, E., 2005, Evapotranspiration of horticultural crops in an unheated plastic greenhouse: Agricultural Water Management, v.72, no.2, p. 81-96, http://dx.doi.org/10.1016/j.agwat.2004.09.010.

Phillips, S.P., and Belitz, Kenneth, 1991, Calibration of a textured-based model of a ground-water flow system, western San Joaquin Valley, California: Groundwater, v.29, no.5, p. 702-715, http://dx.doi.org/10.1111/j.1745-6584.1991.tb00562.x.

Phillips, S.P, Green, C.T., Burow, K.R., Shelton, J.L., and Rewis, D.L., 2007, Simulation of multiscale groundwater flow in part of the northeastern San Joaquin Valley, California: U.S. Geological Survey Scientific Investigations Report 2007-5009, 43 p., http://pubs.er.usgs.gov/publication/sir20075009.

Poeter, E.E., Hill, M.C., Banta, E.R., Mehl, Steffen, and Christensen, Steen, 2006, UCODE_2005 and six other computer codes for universal sensitivity analysis, calibration, and uncertainty evaluation constructed using JUPITER API: U.S. Geological Survey Techniques and Methods, Book 6, Ch. A11, 299 p., http://pubs.er.usgs.gov/publication/tm6A11.

Powell, C.L., II; Barron, J.A., Sarna-Wojcicki, A.M., Clark, J.C., Perry, F. A., Brabb, E.E., and Fleck, R.J., 2007, Age, stratigraphy, and correlations of the late Neogene Purisima Formation, central California coast ranges: U.S. Geological Survey Professional Paper 1740, 32 p., http://pubs.er.usgs.gov/publication/pp1740.

Prudic, D.E., Konikow, L.F., and Banta, E.R., 2004, A new streamflow-routing (SFR1) package to simulate streamaquifer interaction with MODFLOW-2000: U.S. Geological Survey Open-File Report 2004-1042, 104 p., http://pubs.er.usgs.gov/publication/ofr20041042.

Pajaro Valley Water Management Agency, 2007, Basin management plan: last accessed February 11, 2008, http://www.pvwma.dst.ca.us/basin_management_plan/ bmp_documents.shtml.

Raines, Melton, and Carella, 1999, Local water supply alternatives feasibility study: Raines, Melton, and Carella, Inc., Consultants report for Pajaro Valley Water Management Agency, 44p.
Ruehl, C., Fisher, A.T., Hatch, C.E., Los Huertos, Marc, Stemler, G., and Shennan, Carol, 2006, Differential gauging and tracer tests resolve seepage fluxes in a strongly-losing stream: Journal of Hydrology, v.300, no.1-2, p. 235-248, http://dx.doi.org/10.1016/j.jhydrol.2006.03.025.

Ruehl, C.R., Fisher, A.T., Los Huertos, Marc,Wankel, S.D., Wheat, C.G., Kendal, Carol, Hatch C.E., and Shennan, Carol, 2007, Nitrate dynamics within the Pajaro River, a nutrient-rich, losing stream: Journal of North American Benthological Society, v.26, no.2, p. 191-206, http://dx.doi.org/10.1899/0887-3593(2007)26[191:NDWTP R]2.0.CO;2.

Samani, Zohrab, 2000, Estimating solar radiation and evapotranspiration using minimum climatological data: Journal of Irrigation and Drainage Engineering, v.126, no.4, p. 265-267, http://dx.doi.org/10.1061/(ASCE)07339437(2000)126:4(265).

Santa Cruz County, 2009, Geographic Information System, last accessed December 2010, http://gis.co.santa-cruz.ca.us/ GIS/File_Download_Site/home.html.

Schmid, Wolfgang, and Hanson, R.T., 2009, The farm process version 2 (FMP2) for MODFLOW-2005Modifications and upgrades to FMP1: U.S. Geological Survey Techniques and Methods, Book 6, ch.A32, 103 p., http://pubs.er.usgs.gov/publication/tm6A32.

Schmid, Wolfgang, Hanson, R.T., Maddock III, Thomas, and Leake, S.A., 2006a, User guide for the farm process (FMP1) for the U.S. Geological Survey's modular threedimensional finite-difference ground-water flow model, MODFLOW-2000: U.S. Geological Survey Techniques and Methods Book 6, ch.A17, 139 p., http://pubs.er.usgs.gov/publication/tm6A17.

Schmid, Wolfgang, Hanson, R.T., and Maddock III, Thomas, 2006b, Overview and advances of the farm process for MODFLOW-2000: Managing Groundwater SystemsConference Proceedings, International Groundwater Modeling Center, Golden, CO, May 21-24, 2006 , p. 23-27.

Schmidt, Calla, Fisher, A., Racz, A., Los Huertos, Marc, and Lockwood, B., 2009, Process and controls on rapid nutrient removal during managed aquifer recharge: HydroVisions, Winter 2009, v.18, No.4, Groundwater Resources Association of California, pp. 19-22, http://www.grac.org/hv/winter09.pdf.

Smith, C., 2000, PVIGSM Alternative Analysis: Technical Memorandum 5 for subtask 6.1, Consultants report to PVWMA from Montgomery Watson, variously paged.

Snyder, R.L., and Eching, Simon, 2002, Penman-Monteith daily (24-hour) reference evapotranspiration equations for estimating $\mathrm{ET}_{\mathrm{o}}, \mathrm{ET}_{\mathrm{r}}$ and $\mathrm{HS} \mathrm{ET}_{\mathrm{o}}$ with daily data. 
Snyder, R.L., and Schulbach, K.F., 1992, Central coast crop coefficients for field and vegetable crops: California Department of Water Resources, Water Conservation Office, Drought Tips No. 92-45, 4 p., http://www.dwr.water.ca.gov/ pubs/drought/central_coast_crop_coefficients_for_field_ and_vegetable_crops_drought_tip_92-45_192-45.pdf.

Snyder, R.L., Lamina, B.J., Shaw, D.A., and Pruitt, W.O., 1987a, Using reference evapotranspiration $\left(\mathrm{ET}_{\mathrm{o}}\right)$ and crop coefficients to estimate crop evapotranspiration (Etch) for agronomic crops, grasses, and vegetable crops: Leaflet 21427, Cooperative Extension of the University of California Division of Agriculture and Natural Resources, Berkeley, California, $12 \mathrm{p}$.

Snyder, R.L., Lamina, B.J., Shaw, D.A., and Pruitt, W.O., 1987b, Using reference evapotranspiration (ET $)$ and crop coefficients to estimate crop evapotranspiration (Etch) for trees and vines: Leaflet 21428, Cooperative Extension of the University of California, Division of Agriculture and Natural Resources, Berkeley, California, 8 p.

Teghavi, S.A., and Smith, Chris, 1999a, PVIGSM Hydrologic database: Technical Memorandum 1.1 for subtask 6.1, Consultants report to PVWMA from AT Associates and Montgomery Watson, variously paged.

Teghavi, S.A., and Smith, Chris, 1999b, PVIGSM Land use and agricultural crop mix: Technical Memorandum 2.2 for subtask 6.2, Consultants report to PVWMA from AT Associates and Montgomery Watson, $11 \mathrm{p}$.

Teghavi, S.A., and Smith, Chris, 1999c, PVIGSM Finite element refinements and subregion redefinition: Technical Memorandum 2.1 for subtask 6.1, Consultants report to PVWMA from AT Associates and Montgomery Watson, 2 p.

Teghavi, S.A., and Smith, Chris, 1999d, PVIGSM Water use and pumping estimates: Technical Memorandum 2.3 for subtask 6.2, Consultants report to PVWMA from AT Associates and Montgomery Watson, 11p.

Teghavi, S.A., and Smith, Chris, 1999e, PVIGSM Geologic database refinement: Technical Memorandum 1.2 for subtask 6.1, Consultants report to PVWMA from AT Associates and Montgomery Watson, 2p.

Teghavi, S.A., and Smith, Chris, 1999f, PVIGSM Recalibration process and results: Technical Memorandum 3 for subtask 6.1, Consultants report to PVWMA from AT Associates and Montgomery Watson, 13p.

Teghavi, S.A., and Smith, Chris, 1999g, Baseline conditions and basin sustainable yield analysis: Technical Memorandum 4 for subtask 6.1, Consultants report to PVWMA from AT Associates and Montgomery Watson, 9 p.
Temesgen, Bekele, Eching, Simon, Davidoff, Baryohay, and Frame, Kent, 2005, Comparison of some reference evapotranspiration equations for California: Journal of Irrigation and Drainage Engineering, v.131, no.1, p.73-84, http://dx.doi.org/10.1061/(ASCE)07339437(2005)131:1(73).

Theberge, Captain A.E., 2010, 150 years of tides on the western coast: The longest series of tidal observations in the Americas: NOAA Central Library, 15 p., http:// oceanservice.noaa.gov/topics/navops/ports/150_years_of tides.pdf.

U. S. Bureau of Reclamation, 1998, Water Service Providers' Boundary Maps data via ftp: U.S. Bureau of Reclamation, various coverages, accessed May 1998, ftp://www.mp.usbr. gov/pub/geopage, (no longer available)

U.S. Geological Survey, 2010, National handbook of recommended methods for water data acquisitionCh.11, Water Use, last accessed July 2013, http://water.usgs.gov/watuse/.

U.S. Geological Survey, 1990, Land use and land cover digital data from 1:250,000- and 1:100,000-scale maps, Data user guide 4, Reston, Virginia, http://pubs.er.usgs.gov/publication/70038386.

U.S. Geological Survey, 1999, National land cover digital data, http://edc.usgs.gov/products/landcover/nlcd.html.

U.S. Geological Survey, 1999, National Elevation Dataset (NED): Digital Elevation Model (DEM) Dataset and Metadata, U.S Geological Survey Eros Data Center, Sioux Falls, South Dakota, accessed May 29, 2007, http://gisdata.usgs.net/ned/.

U.S. Department of Agriculture, Natural Resources Conservation Service, 2005, Soil Survey Geographic (SSURGO) Database: USDA Natural Resources Conservation Service, accessed September 12, 2005, http://www.ncgc.nrcs.usda.gov/products/datasets/ssurgo/.

Wagner, D.L., and Pridmore, C.L., 1991, Preliminary geologic map of the Monterey 1:100,000-scale quadrangle, California: a digital map database: California Division of Mines and Geology, digital database prepared by Brown, K.M., Colgan, J.P., Nicholson, R.S., Robinson, J.E., and Wentworth, C.M., 1999, U.S. Geological Survey.

Woodward-Clyde Consultants, 1983, Results of drilling and hydrogeologic testing in the Pajaro Valley area, California: Consultants report to H. Esmaili and Associates, Inc., January 1983, $22 \mathrm{p}$. 
Prepared by the Sacramento Publishing Service Center.

For more information concerning this report, contact:

Director

U.S. Geological Survey

California Water Science Center

6000 J Street, Placer Hall

Sacramento, CA 95819

dc_ca@usgs.gov

or visit our Web site at:

http://ca.water.usgs.gov 
